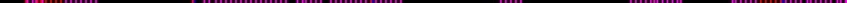


Gyermekvédelmi intézményekben elhelyezett gyerekek életkörülményei 

Rákó Erzsébet

\section{GYERMEKVÉDELMI \\ INTÉZMÉNYEKBEN ELHELYEZETT GYEREKEK ÉLETKÖRÜLMÉNYEI}

\section{BF琶旙EDERE}

Szeged

2014 
Lektorálta:

Dr. Mojzesné Dr. Székely Katalin

Dr. Jancsák Csaba

Nyelvi lektor:

Dr. Gyürky Katalin

Boritóterv:

Majzik Andrea

ISBN 9786155372056 (print)

ISBN 9786155372063 (pdf)

(C) Rákó Erzsébet, 2014

(C) Belvedere Meridionale, 2014 


\section{TARTALOM}

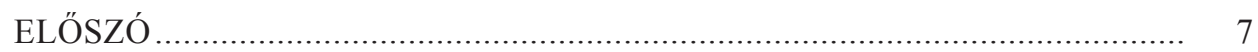

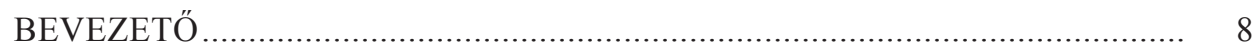

1. A SZOCIALIZÁCIÓ JELENTŐSÉGE, A GYERMEKVÉDELMI INTÉZMÉNY, MINT SZOCIALIZÁCIÓS SZÍNTÉR ……………………………………..... 11

1.1. A szocializáció fogalma ……....................................................... 11

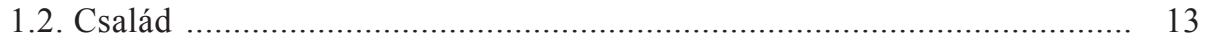

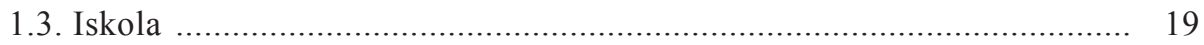

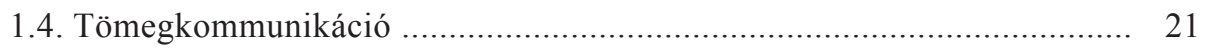

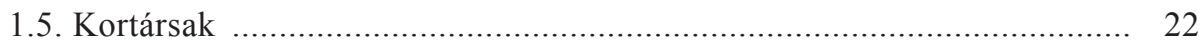

1.6. A gyermekvédelmi intézmény, mint speciális szocializációs színtér ........ 23

2. A GYERMEKVÉDELEM EURÓPÁBAN - NEMZETKÖZI KITEKINTÉS .. 30

2.1. A nyugat-európai országok gyermekvédelme ……….......................... 32

2.2. A kelet-közép európai országok gyermekvédelme ………….................. 39

2.3. Közös vonások és eltérések .............................................................. 48

3. A GYERMEKVÉDELEM RENDSZERE MAGYARORSZÁGON .............. 54

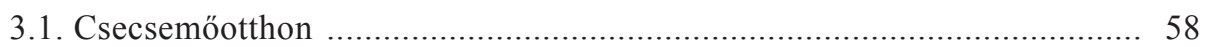

3.2. Gyermekotthon, lakásotthon, utógondozó otthon ................................. 61

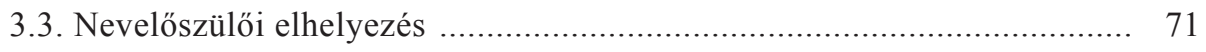

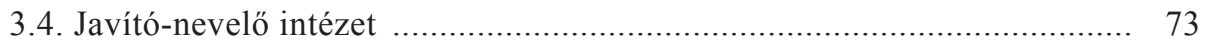

4. INTÉZMÉNYBEN ÉLŐ GYEREKEK AZ EMPIRIKUS KUTATÁSOK

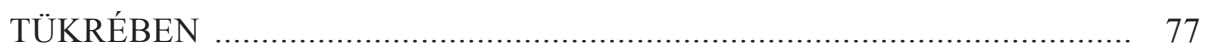

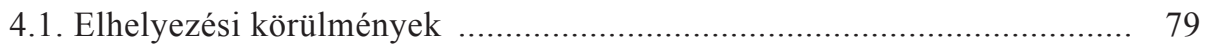

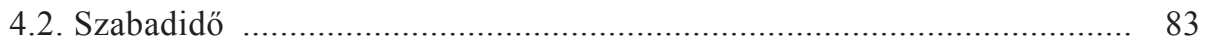

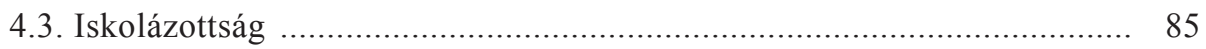

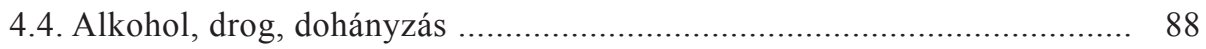

4.5. Az intézményekben élő cigány gyerekek .............................................. 91

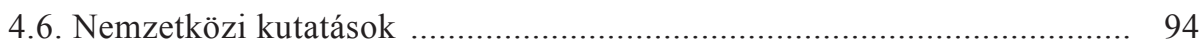


5. A HAJDÚ-BIHAR MEGYEI GYERMEKOTTHONOKBAN, LAKÁSOTTHONOKBAN ÉLÖ GYEREKEK ÉLETKÖRÜLMÉNYEI ....... 98

5.1. A kutatás jellemzői ............................................................... 98

5.1.1. A kutatás célja, háttere ....................................................... 98

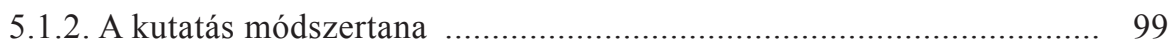

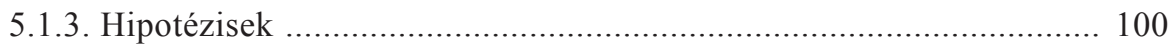

5.1.4. A minta jellemzése ............................................................ 100

5.1.5. A kutatás eszköze ................................................................ 101

5.2. A kérdőíves vizsgálat eredményei ................................................. 101

5.2.1. Demográfiai adatok, családi állapot, intézménybe való bekerülés ..... 101

5.2.2. Szülők, családi/rokoni kapcsolatok, kapcsolattartás a családdal ........ 104

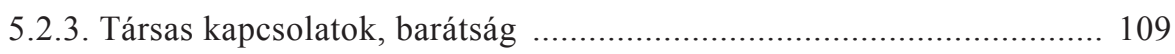

5.2.4. Szabadidő..................................................................... 113

5.2.5. Iskolai tanulmányok/munkavégzés ....................................... 124

5.2.6. Alkohol, drog, dohányzás kipróbálása, használata ....................... 129

5.2.7. Értékek, valláshoz való viszony ............................................. 133

5.2.8. Intézeti környezetre vonatkozó kérdések, elégedettség, jövőterv ...... 137

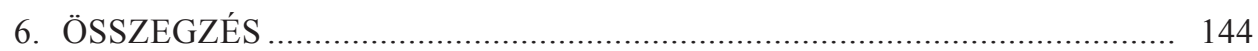

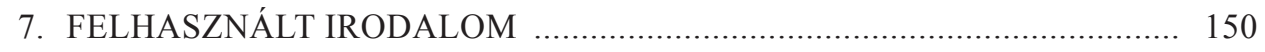

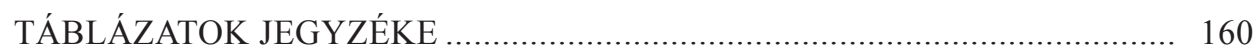

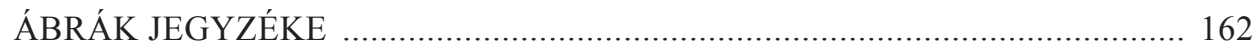




\section{ELŐSZÓ}

Ez a könyv az általam készített disszertáció rövidített szerkesztett változatát tartalmazza. A disszertáció központi kérdése az, hogy az elhelyezési lehetőségek változásával hogyan alakultak az intézményben élö gyerekek életkörülményei. További kérdésként merült fel, hogy mennyire elégedettek a gyerekek az elhelyezéssel? Milyen előnyei/hátrányai vannak a különböző típusú intézményi elhelyezésnek? Milyen különbségek vannak a gyermekotthoni és a lakásotthoni körülmények között?

Arra a kérdésre is kerestük a választ, hogy a megváltozott intézményi körülmények hogyan befolyásolják a lakásotthonban, gyermekotthonban elhelyezett fiatalok életkörülményeit. Az összehasonlító vizsgálat keretében feltártuk, hogy milyen különbségek vannak a hagyományos gyermekotthonban és a lakásotthonban elhelyezett gyerekek életkörülményei között. Vizsgáltuk a családi/rokoni kapcsolatokat, a társas kapcsolatrendszert, a szabadidős szokásokat, az iskolai tanulmányokat, az alkohol, a drog, a dohányzás kipróbálását, használatát, az intézményi szolgáltatásokkal való elégedettséget, valamint a jövőképet. Ezeket azért tartottuk fontosnak, mivel nemcsak a fiatalok jelenlegi életkörülményeit befolyásolják jelentősen, hanem az intézményből való kikerülés után a társadalomba való beilleszkedési esélyeiket is.

Témaválasztásomat befolyásolta, hogy a Gyermekvédelmi törvény bevezetésének időszakában gyakorló szakemberként a gyermekjóléti alapellátásban dolgoztam. Érdeklődésemet felkeltette, hogy a törvény bevezetése óta eltelt időszakban hogyan valósult meg a gyermekvédelmi intézmények átalakítása, a benne élő gyerekek, fiatalok helyzete miként változott. A témaválasztás további szubjektív oka az volt, hogy szociálpedagógus hallgatók oktatójaként fontossá vált számomra, hogy ismereteimet bővítsem ezen a területen.

Fontos számomra, hogy a témában megszerzett eddigi ismereteimet megoszszam azokkal a hallgatókkal, akik szociális vagy pedagógus képzésben vesznek részt. Reményeim szerint ezzel felkeltem a hallgatók gyermekvédelem iránti érdeklődését, segíteni tudom a felkészülésüket.

A szerző

Debrecen, 2013. augusztus 26. 


\section{BEVEZETŐ}

A gyermekvédelmi téma aktualitását adja többek között az a tény, hogy a Központi Statisztikai Hivatal adatai szerint a kiskorúak veszélyeztetettsége 2008-ban 1000 lakosra számítva az észak-alföldi régióban volt a legmagasabb. Ebben a régióban ezer 18 év alatti lakosra négyszer több veszélyeztetett jutott, mint a legkedvezőbb helyzetü Közép-Dunántúlon. Az Észak-Alföldön élt a veszélyeztetett gyermekeket nevelő családok 27 százaléka, az egy családra jutó veszélyeztetett kiskorúak száma is itt volt a legtöbb.

A kiskorúak szempontjából kifejezetten hátrányosnak tekinthető az észak-magyarországi és a dél-dunántúli régió is. Ezekben 1000 megfelelő korú kiskorúra vetítve a veszélyeztetett gyerekek száma 129 és 111 volt. Az adatok szerint a gyerekek helyzete a Közép- és Nyugat-Dunántúlon, valamint Közép-Magyarországon a legmegnyugtatóbb. A veszélyeztetett gyerekek régiónkénti száma előrevetíti az intézménybe való bekerülés lehetóségét. Ezeknek az adatoknak megfelelően az intézménybe bekerülö 18 év alatti gyerekek 37 százaléka az ország két gazdaságitársadalmi szempontból hátrányos helyzetủ régiójában lakik, az észak-alföldi és az észak-magyarországi régiókban. Ennek megfelelően a gyermekotthoni féröhelyek kihasználtsága is ebben a két régióban a legmagasabb, az előbbiben $90 \%$, az utóbbiban 96 \%. (Szociális védőháló a régiókban, 2008.) Az intézményben elhelyezett gyerekek magas aránya indokolja, hogy megvizsgáljuk, milyen életkörülmények között élnek a különböző intézményekben, milyen lehetőségeket biztosít a társadalom a gyerekek legkiszolgáltatottabb csoportja számára.

A téma előzményei közé tartozik, és további aktualitását adja, hogy az 1997. évi XXXI. Gyermekek védelméröl és a gyámügyi igazgatásról szóló törvény bevezetésével átalakultak a gyerekek elhelyezési lehetőségei, ami szintén jelentősen befolyásolta a gyerekek életkörülményeit.

A gyermekvédelem többféle összefüggésbe helyezhető és többféle összefüggésben értelmezhető. Így például a szocializáció, a gyermek- és gyermekkor története, a szervezetszociológia, az életmód, az értékek, normák szempontjából is feldolgozható. Könyvünkben a gyermekvédelem elsősorban mint sajátos szocializációs színtér, a gyerekek életkörülményeit biztosító feltételek rendszere jelenik meg.

Az első fejezet adja a téma elméleti keretének kiindulópontját a szocializáció, a gyermekvédelmi intézmény mint szocializációs színtér sajátosságainak bemutatása révén. A szocializációs ágensek áttekintése fontos, mert a gyerekek későbbi életére is jelentősen kihat, hogy hol, milyen keretek között valósult meg a szocializációjuk. Az első fejezetben Bronfenbrenner (1992) ökológiai modelljét felhasználva mutatjuk be a gyermekvédelmi intézményekben megvalósuló szocializáció 
folyamatának sajátosságait. A modellt L. Palareti és C. Berti (2009) alkalmazta először a gyermekotthonokra, lakásotthonokra vonatkozóan. A modell kiindulópontja, hogy a gyerek és az öt körülvevő környezet rendszert alkot, aminek négy szintje van. Ezek a mikro-, mezo-, exo- és makroszintek.

A modell jelentősége abban áll, hogy lehetővé teszi a gyerekek életkörülményeinek a vizsgálatát a különböző szintek elemzésével.

A gyermekvédelem Európában fejezetben a nyugat-európai és kelet-középeurópai országok gyermekvédelmének sajátosságait, tipológiáját mutatjuk be. Az összehasonlító elemzés során azt vizsgáljuk, hogy az egyes országokban milyen elhelyezési lehetőségeket, életkörülményeket biztosítanak a család nélkül maradt gyerekek számára. A fejezetben Gottesman (1991), Madge (1994) nemzetközi öszszehasonlító vizsgálatainak eredményeit, valamint az UNICEF Innocenti Research Center kutatási eredményeit használtuk fel.

A gyerekek elhelyezési lehetőségeinek összehasonlító elemzésére a harmadik fejezetben kerül sor. Feltárjuk, hogy milyen változások történtek az 1997 előtti és utáni időszakban, milyen lehetőségek vannak a gyerekek elhelyezésére jelenleg. Kiemelt szerepet kap a Központi Statisztikai Hivatal gyermekvédelmi intézményekre és az ott elhelyezett gyerekekre vonatkozó adatai. A statisztikai adatok elemzésével tesszük szemléletessé a gyerekek életkörülményeit meghatározó tényezőket (iskolai végzettség, továbbtanulás, gyerekcsoportok száma, szökések száma stb.) Az elemzésben rámutatunk azokra a dimenziókra, ahol egyértelmü javulás tapasztalható.

A negyedik fejezetben olyan hazai, empírikus vizsgálatokat és azok eredményeit mutatjuk be, amelyek az intézményekben élő gyerekek életkörülményeivel foglalkoznak. Így az elhelyezési lehetőségekre, a szabadidő eltöltésére, iskolázottságra, a gyerekek alkohol-, drog- és dohányzási szokásaira vonatkozó kutatásokat tekintjük át. Kiemelten foglalkozunk Hanák (1978) vizsgálatával, amely a későbbi kutatásokat, illetve a magyar gyermekvédelmet is megalapozta. A fejezet egy részében a hazaihoz tematikusan kapcsolódó nemzetközi kutatásokat mutatunk be, amelyek az intézményben élő gyerekek problémáit tárják fel a különböző országokban.

Az ötödik fejezetben bemutatjuk a Hajdú-Bihar megyei gyermekotthonokban, lakásotthonokban élő fiatalok körében végzett kérdőíves vizsgálat eredményeit. A kutatás területi határainak megvonása nem volt egyszerü. Egy megye - annak ellenére, hogy konstruált, mesterséges egység - eléggé emberléptékü, általunk is „bejárható". Ugyanakkor nagyságrendje is elegendő ahhoz, hogy a szociológia kívánalmainak megfeleljen. Ezzel elkerülhető az esetlegesség, a puszta illusztráció veszélye. Az országnak egy darabja, ami lehet jobb is, rosszabb is, mint az egész. Van saját történelme - saját múltja, jelene -, amely különbözik az ország egészétől és ebben az eltérésben sok minden válik mérhetővé, s mi több, megérthetővé is. (Losonczi, 1989) 
Kutatásunk során kérdőíves vizsgálatot végeztünk, amelyben 13-25 éves fiatalok életkörülményeit tárjuk fel, valamint azt, hogy az intézményi elhelyezés változása hogyan hatott a gyerekek mindennapjaira. Az elemzett változókat nem, etnikum és gondozási hely szerint mutatjuk be. Az adatoknak megfelelő statisztikai próbákat alkalmaztunk, leggyakrabban független t-próbát, egymintás t-próbát és $\chi^{2}$-próbát. Az empírikus elemzés során a gyermekotthonokban, lakásotthonokban élő megkérdezettek demográfiai adatait, családi kapcsolatait, társas kapcsolatrendszerét, szabadidejét, iskolai tanulmányait, értékekhez való viszonyát, alkohol-, drogfogyasztási szokásait, majd általános elégedettségét, jövőképét hasonlítjuk össze.

Az összehasonlító elemzéssel célunk a gyerekek életkörülményeinek bemutatása mellett az volt, hogy rávilágítsunk a kisebb léptékü, családias körülményeket biztosító lakásotthoni elhelyezés előnyeire. A vizsgálat során alkalmazható a Bronfenbrenner (1992) nevével fémjelzett, ökológiai modell. Mikroszinten vizsgálható a gyerekek és a felnőttek közötti kapcsolat alakulása: meg tudják-e beszélni a problémáikat a nevelőkkel, kapnak-e tölük segítséget a nehézségeik megoldásához, elégedettek-e a nevelőkkel. A gyerekek társas kapcsolatrendszerét, a baráti kapcsolatok alakulását is ezen a szinten érdemes vizsgálni. A fizikai környezet közvetlenül befolyásolja életkörülményeiket, így a különböző típusú intézmények elhelyezési feltételeinek összehasonlító elemzése is indokolt. A mezorendszer elemei közül az iskolát, a szabadidős lehetőségeket, az értékekhez, vallásosságot, az alkohol, a drog és a dohányzási szokások alakulását, a gyerekek jövőre vonatkozó elképzeléseit vizsgáljuk. Ezek mind befolyásolják a gyerekek mindennapjainak alakulását. Az exorendszer szintjén az intézmények külső kapcsolatrendszerét, valamint a családokkal való kapcsolattartást mutatjuk be. Makroszinten elsősorban a gyermekvédelem rendszere, az állam által elöírt törvények, szabályok és ezek megvalósítása jelenik meg az egyes fejezetekben.

Az utolsó összegzést tartalmazó fejezetben hipotéziseink igazolására kerül sor. 


\section{A SZOCIALIZÁCIÓ JELENTŐSÉGE, A GYERMEKVÉDELMI INTÉZMÉNY, MINT SZOCIALIZÁCIÓS SZÍNTÉR}

A fejezetben a szocializáció értelmezési kérdéseit, elméletét és színtereit tekintjük át. A szocializáció fontos, mert e folyamat keretében sajátítják el a gyerekek a normákat, értékeket, továbbá megtanulják, hogyan kell a társadalomban élni. A gyerekek életkörülményeit jelentősen befolyásolja, hogy hol valósul meg a szocializációjuk, valamint az is milyen a kapcsolat az egyes színterek között. A gyermekvédelmi intézmények sajátos szocializációs színtérként müködnek. Elsősorban ezekre az intézményekre és a bennük megvalósuló szocializációs folyamat sajátosságaira fókuszálunk, mivel az eddigi kutatások erre kevés figyelmet fordítottak.

\subsection{A szocializáció fogalma}

A szocializáció értelmezésével több tudomány, így a pszichológia, az antropológia és a szociológia foglalkozik. A pszichológia a társadalmi viselkedés szempontjából lényegbevágó egyéni jellegzetességek alakulására összpontosítja a figyelmét, valamint azokat a folyamatokat vizsgálja, amelyek révén ezek a viselkedési tendenciák megtanulhatók. Az antropológia a szocializációs tapasztalatok általános határainak meghatározásában közremüködő szélesebb kultúra nézőpontjából szemléli a szocializációt. A szociológia azoknak a sajátos csoportoknak és intézményeknek a jellegzetességeit kutatja, amelyeknek közegében a szocializáció végbemegy, valamint azokat a közös készségeket vizsgálja, amelyeket az egyének változatos összefüggésekben elsajátítanak. (Goslin, 1976) A következőkben elsősorban a szociológia értelmezési keretét használva tekintjük át a szocializáció fogalmát.

A szocializációval a 20. században kezdtek széleskörüen foglalkozni a társadalomkutatók. A kutatások kezdete az 1920-as évekre vezethető vissza, mégpedig a chicagói városszociológusok tevékenységének idejére. Vizsgálódásaik középpontjában a városi övezetek és szubkultúrák kialakulásának életének feltérképezése, a városszerkezet szabályszerúségeinek, illetve olyan szociális problémáknak az értelmezése állt, mint a nyomor és a bünözés. A szocializáció fontos társadalomelméleti összefüggéseinek kérdésköre itt, a chicagói városi élet vizsgálatakor kezdett kirajzolódni. (Somlai, 2008)

A különböző szociológiai irányzatok szocializáció értelmezése eltér egymástól. A szimbolikus interakcionizmus az emberek közötti kapcsolatok kutatását helyezi a középpontba. Az irányzat képviselöi a szocializációt kétirányú folyamatként ér- 
telmezik. Az egyén hat a társadalomra a megnyilvánulásain keresztül és az egyén a szimbolikusan közvetített interakció folyamatában képes megváltoztatni a másik magatartását, ezzel hozzájárul a társadalom fejlődéséhez. Az ember úgy válik a társadalom tagjává, hogy belsővé teszi annak a csoportnak a magatartási szabályait, amelyhez tartozik. ( H. Mead, 1973)

A szocializációhoz szorosan kapcsolódik a szerep fogalma. A szerep viselkedési mintákból, jogokból és kötelességekből áll. A szocializáció arra a folyamatra utal, amelynek során az egyének a társadalomban való hatékony részvételük érdekében számos társadalmi szerepet sajátítanak el, vagyis arra, hogyan szerzik meg az egyének azt a tudást, azokat a készségeket, és miként alakítják ki magukban azokat a diszpozíciókat, amelyek képessé teszik őket arra, hogy a többiek elvárásaiknak megfelelően teljesítsék szerepüket. (Goslin, 1976)

A struktúralista-funkcionalista elmélet is kiemelt jelentőséget tulajdonít a szocializációnak. A személyiséget társadalmi alrendszernek tekintve fontosnak tartja a társadalom fennmaradásához szükséges normák, értékek átadását. Míg a szimbolikus- interakcionizmus az emberek közötti kapcsolatot helyezi a középpontba, addig a struktúralista funkcionalista megközelítés a szocializáció kulcsfogalmának az internalizációt tekinti. A szocializáció során átvesszük és bensőnkké alakítjuk a környezetünk tudását és mintáit, szabályait és szempontjait. A szocializáció akkor tekinthető sikeresnek, ha az egyén felismeri a vele szemben támasztott elvárásokat, eleget tesz azoknak és képes betölteni a szerepeit. Ebben a tanulási folyamatban öt szakasz különíthető el, a megerősítés-kioltás, gátlás, helyettesítés, utánzás, azonosulás. (Parsons, 1966)

A fenomenológiai szociológia szerint a szocializáció többet jelent a magatartásminták elvileg bármikor helyettesíthető vagy változtatható követésénél. Elsősorban azonosulások folyamatait és a szerepek, az én, illetve az identitás képződésének szociális müveleteit jelenti, amelyek nyomán bensőnkké válik a köznapi világ. Ugyanakkor ez a valóság már a kezünk nyomát is magán viseli. A szociális stuktúrák és a szimbolikus jelentésrendszerek elsajátításával mindig hozzájárulunk magunk is e világ fenntartásához, és/vagy módosításához. (Somlai, 2008)

A szocializációt a kulturális átörökítés folyamataként határozza meg Somlai (1997), és három elméletet különít el a folyamat értelmezése során. Az első a rekonstruktivizmus. Ide tartozik a struktúralista- funkcionalista szociológia, de más pszichológiai és kultúrantropológiai elméletek is. E szerint a megközelítés szerint az új nemzedékek újjáteremtik azokat a kulturális, szociális mintákat, amelyek már a szüleik világában is természetes keretei voltak az egyén magatartásának. A második elmélet a kritikai irányzatokat foglalja magába. Ez mutat rá arra, hogy a beilleszkedés nem természeti adottság, hanem történelmileg alakult ki a változó viszonyok, emberek és embercsoportok között. A harmadik a konstruktivizmus. Az egyén cselekvő, aktív részvételét, fontosságát hangsúlyozza a szocializáció folyamatában. (Somlai, 1997) 
A szocializáció lényeges elemének a tanulást tartja Cseh-Szombathy (1979), amely során az egyén nemcsak befogad, hanem a kapott hatásokat feldolgozza, és ennek következtében fejlödik a személyisége. A szocializáció eredményeként alakul ki az alkalmazkodási készség a társadalom valamint a csoport magatartási követelményeihez.

A szocializáció bevezetés a társadalomba, a társadalmasodásra utaló kifejezés, amely azt a folyamatot jelenti, amelyben a gyermeket és a fiatalokat bevezetik a társadalomba. E folyamatban biológiai lényből társadalmi lénnyé válnak. (Mojzesné, 2002)

A szocializáció fogalmának értelmezése során Andorka (2006) azt emeli ki, hogy az egyén elsajátítja azokat a társadalmi szerepeket, amelyeket élete folyamán be kell töltenie. A szerepviselkedési mintákból, jogokból, kötelességekből áll. Különböző státusokhoz, különböző szerepek tartoznak. A státus egy társadalomban elfoglalt pozíciót jelent.

A szocializációt a perszonalizáció fogalmával egészíti ki Kozma (1999). A szocializációs- perszonalizációs folyamatnak két eredménye van. A közösség szintjén, hogy a közösség megőrzi a közösen szerzett tudást, amit átad a következő generációnak. Az egyén szintjén pedig azt eredményezi, hogy az egyén beilleszkedik a közösségbe, és miközben beilleszkedik, kialakul a személyisége.

A gyermekkor rendkívül fontos időszak a szocializáció szempontjából. A szociológusok szerint ez a folyamat az egész emberi élet során tart, átszövi valamennyi tevékenységünket és különféle színtereken valósul meg. A szakirodalomban a szocializációs színterek két nagy csoportja különböztethető meg. A klasszikus szociológia a szocializáció színtereit az intézményes és spontán szocializációra bontja. Az általában elfogadott család és iskola mellett jelentősek az egyéb intézmények (mint a munkahely, a politikai párt, az egyház). Önálló jelentőségre tett szert a tömegkommunikáció, illetve a művelődési intézmények (a müvelődési házaktól, a könyvkiadóktól a színházakig). A spontán szocializáció a kortárs csoportokat, a barátokat és a társadalom egészét jelenti. (Mojzesné, 2002)

A következőkben elöször az intézményes, majd a spontán szocializáció színtereit mutatjuk be. Így a családot, az iskolát, a tömegkommunikációt, a kortárskapcsolatot tekintjük át Somlai (1997) felosztása alapján. Ezt a felosztást kiegészítjük a gyermekvédelmi intézmény, mint sajátos szocializációs színtér elemzésével.

\subsection{Család}

A család a gyermek elsődleges szocializációs színtere, a normák, értékek, szerepek átadásának terepe. A szociológia a családot elsődleges csoportnak tekinti. A szocializáció első gyakorlótere, ahol többek között az együttélés, a munka, a gazdálkodás szabályait sajátítjuk el. A család nemcsak olyan értelemben elsődleges 
közössége az embernek, hogy az élete során időben ezzel az együttélési formával ismerkedik meg elsőként, hanem úgy is, miszerint ez az a közösség, amely egész életén át végigkíséri az egyént, legalábbis a családi szocializáció során kialakított értékek révén. (Utasi, 1989)

A családi funkciók közé tartozik a termelés-gazdálkodás, a fogyasztás, a reprodukció, a gyermek szocializációja, a lelki gondozás. (Kulcsár 1969, CsehSzombathy 1979, Andorka 2006)

A családi funkciók az elmúlt években is sokat változtak. Mára a termelö funkciót a fogyasztás és gazdálkodás váltotta fel. De továbbra sem elhanyagolható a termelö funkció, mivel ma is müködnek gazdaságok, amelyek maguknak termékeket állítanak elő. A családok egy szük körében kétségtelenül megmaradt, sőt Magyarországon a rendszerváltást követően - esetenként hangsúlyosabbá is vált a családi gazdálkodás, vállalkozás, vagyis a hagyományos családi gazdasági termelő funkció. Ám a technikai fejlődés következtében, a korábbiakhoz képest kevesebb családtag számára ad munkalehetőséget. (Utasi, 2002)

A család szocializációs funkciója kiemelt fontosságú a gyermek számára, biztosítja a személyiségfejlődését. A társadalom egészének fennmaradásához a család a gyermekszüléssel és a gyermekek szocializálásával járul hozzá, biztosítja a népesség fizikai és minőségi reprodukcióját, a családot alkotó egyének személyiségének stabilitását pedig a család feszültségoldó szerepe segíti elő. (Cseh-Szombathy, 1979)

A család nem mindig tudja teljesíteni a funkcióit. Abban az esetben, ha a család nem tudja ellátni a szocializációs funkciót, akkor kerülhet sor a gyermek intézményben való elhelyezésére. A család szocializációs szerepe jelenleg pótolhatatlan. A kényszerüségből állami gondozásba vett gyermekek számos hátrányt szenvednek a család hiánya miatt. (Andorka, 2006.)

Az állami gondozásban élő gyerekek családja több olyan sajátosságot mutat, ami nehezíti vagy akadályozza őket abban, hogy megfelelő szocializációs színteret biztosítsanak a gyerekeik számára. Jellemző rájuk az átlagosnál nagyobb családnagyság, az egyszülős vagy felbomlott családok magas aránya, gyakoriak az egészségügyi problémák, a szegénység. A családon belül erős a fluktuáció, könnyen engednek el családtagokat és könnyen fogadnak be újakat. Ezekben a családokban gyakoriak a konfliktusok, az erőszak, a deviáns magatartási minták. (Hanák 1978, Kerezsi 1995, Vidra-Szabó, 2001, Herczog, 2007)

A következőkben azokat a családban bekövetkező változásokat tekintjük át, amelyek befolyásolják a benne élő gyermekek helyzetét, körülményeit, szocializációját, védelmének szükségességét. A modern családra jellemző változás, hogy egyre több lett a két-, három-, legfeljebb négytagú és egyre kevesebb az ennél nagyobb létszámú család. Csökkent a nagyszülőkkel és más rokonokkal együtt élő konjugális családok aránya, növekedett viszont az egyszülős családoké és egyre gyakoribbak azok az életformák, amelyekben válás, vagy özvegyülés következtében az emberek egyedül élnek. (Somlai, 1986) 
A családi életformák pluralizálódtak. Ez azt jelenti, hogy a két házas szülőből és a gyermekeikből álló családtípus mellett számos más típus is előfordul a társadalomban, például az élettársként való együttélés gyermekek nélkül vagy közös gyermekekkel, második házasságkötés utáni együttélés az első házasságból származó gyermekkel stb. (Andorka, 2006)

1. táblázat. A családok családösszetétel és a száz családra jutó gyermekek száma szerint, 1970-2001

\begin{tabular}{|c|c|c|c|c|}
\hline Családösszetétel & 1970 & 1980 & 1990 & 2001 \\
\hline Házaspáros típusú család összesen & 107 & 101 & 101 & 102 \\
\hline házaspár & .. & .. & 101 & 104 \\
\hline élettársi kapcsolat & & & 89 & 85 \\
\hline Házaspáros típusú család gyermekkel & 171 & 167 & 169 & 171 \\
\hline házaspár & .. & .. & 169 & 171 \\
\hline élettársi kapcsolat &. & .. & 178 & 170 \\
\hline Egyszülős családok & 149 & 140 & 143 & 140 \\
\hline apa gyermekkel & 140 & 141 & 145 & 133 \\
\hline anya gyermekkel & 150 & 139 & 143 & 140 \\
\hline Családok összesen & 111 & 105 & 107 & 108 \\
\hline Gyermekes családok összesen & 167 & 162 & 163 & 163 \\
\hline
\end{tabular}

Forrás: Népszámlálás 2001. 19. Családtípusok, családformák. KSH Budapest. 2004. 23. o.

Az 1. táblázat adatai alapján megállapítható, hogy lényeges az eltérés a különböző típusú családokban élő gyermekek átlagos száma között: 2001-ben minden 100 párkapcsolaton alapuló családban átlagosan 171, minden egyszülős családban pedig 140 gyermek élt. Mind az együttélő, mind az egyszülős családok két-két típusában eltérő a családban élő gyermekek átlagos száma. A párkapcsolaton alapuló családok körében a házaspárok alkotta családokban 100 családra 104, ugyanennyi élettársi kapcsolatra viszont csak 85 gyermek jut. Az egyszülős családok közül az anya gyermekkel típusúak a legnépesebbek. Az adatok gyermekvédelmi szempontból való értelmezése elgondolkodtató. Az egyszülös családokban nevelkedő gyerekek száma magas, és ez azért jelent problémát, mert ők több szempontból is kiszolgáltatottak. Elegendő csak a szülő betegségére gondolni, és azonnal szükség van valamilyen gyermekjóléti-gyermekvédelmi intézkedésre.

Jelentősen befolyásolja a családok életét és benne a gyermekek szocializációját a válások számának a növekedése. A 1990-ben 66405-en, 2000-ben már csak 48110-en, 2006-ban pedig 44528-an kötöttek házasságot. A válások száma 1990-ben 
24888, 2000-ben 23987, 2006-ban pedig 24869 volt. (Demográfiai évkönyv, 2007) Az adatokból jól látszik, hogy a válások száma nem emelkedett az elmúlt években, a házasságkötések száma pedig csökkenő tendenciát mutat. Az adatokból megállapítható a házasságok bomlékonysága, minden második házasság válással végződik. A válások számának növekedése miatt az egyszülős családok száma is nőtt az elmúlt években. Míg a nők házasságkötése és gyermekvállalása egyre későbbi életkorra tolódik, a válások 20-24 éves életkorban a leggyakoribbak. A válások 17 százaléka a házasság első három évében történik, és csaknem felénél tíz évnél rövidebb ideig éltek együtt házasságban a párok. A válások 73 százalékánál legalább egy közös gyermek született a korábbi házasságból és összességében évente 31 ezer gyermek sorsát érinti. Ezek 80 százaléka közös kiskorú gyermek. A bontóperek 72 százalékát a volt feleség kezdeményezi, és az esetek döntő többségében a gyermek elhelyezése is a volt feleségnél történik. (Kamarás, 2001.)

2. táblázat. Az egyszülős családok számának és összetételének alakulása, 1970-2001

\begin{tabular}{|c|c|c|c|c|c|c|c|}
\hline \multirow{3}{*}{ Év } & \multirow{2}{*}{ Összes } & Apa & Anya & \multirow{3}{*}{$\begin{array}{c}\text { Egyszülös } \\
\text { családok } \\
\text { aránya az } \\
\text { összes család } \\
\text { százalékában }\end{array}$} & \multirow{2}{*}{ Összesen } & Apa & Anya \\
\hline & & \multicolumn{2}{|c|}{ gyermekkel } & & & \multicolumn{2}{|c|}{ gyermekkel } \\
\hline & \multicolumn{3}{|c|}{ családok száma (ezerben) } & & \multicolumn{3}{|c|}{ százalék } \\
\hline 1970 & 293 & 37 & 256 & 10,2 & 100 & 12,7 & 87,3 \\
\hline 1980 & 341 & 56 & 285 & 11,3 & 100 & 16,4 & 83,6 \\
\hline 1990 & 450 & 89 & 361 & 15,5 & 100 & 19,8 & 80,2 \\
\hline 2001 & 472 & 58 & 413 & 16,5 & 100 & 12,4 & 87,6 \\
\hline
\end{tabular}

Forrás: Népszámlálás 2001. 19. Családtípusok, családformák. KSH Budapest. 2004. 17. o.

A 2. táblázat adatai is azt szemléltetik, hogy az egyszülös családok aránya növekvő tendenciát mutat, és ezek a családok leginkább „anya gyermekkel” típusúak, ahol az anya él együtt egy vagy több gyerekével. Az ilyen családok életszínvonala minden társadalmi rétegben alacsonyabb, mint a teljes családoké. Az egyszülős családokban élő gyerekek gyakrabban betegednek meg, közöttük több a veszélyeztetett, a bünöző, többen kerülnek állami gondozásba. (Somlai, Tóth, 2002.)

A válás gyermekre gyakorolt hatását számos társadalomtudományi, főként pszichológiai tárgyú tanulmány is bemutatja. A válás nem hirtelen bekövetkező esemény, hanem hosszú, konfliktusokkal teli folyamat előzi meg. A durvaság, a nem megfelelő hangnem, a konfliktus gyakran a gyermek előtt zajlik, így a személyiség fejlődésére negatív hatást gyakorol.

A házassági konfliktusokat elemezve három okot különítenek el a kutatók. Az első okot a házastársak személyisége jelenti, ahol az ellentétek az egyéni szük- 
ségletek, magatartási mechanizmusok ütközéséből következnek. A második okot a családi mikroközösség alkotja, amelynek müködéséből következnek bizonyos ellentétek. A harmadik ok a makrotársadalomban rejlik: a társadalmi struktúra, ennek változása, a házastársaknak a struktúrában elfoglalt helye, ebből következő szerepei, a társadalom általános norma- és célrendszere, az egyes szubkultúrák eltérései mind kihatnak a házastársak kapcsolatának alakulására, és konfliktusokat támasztanak közöttük. (Cseh-Szombathy, 1985)

A válással a gyereket több szempontból veszteség éri. Jól kimutatható az anyagi helyzet romlása, amely a gyerek életmódját, lehetőségeit negatívan befolyásolja. Ennél lényegesebbek az érzelmi zavarok. A gyerek elveszíti biztonságérzetét azáltal, hogy az egyik szülö kilép a családból. Zavarossá válik a nagyszülőkkel, rokonokkal való kapcsolat, ami tovább fokozódik, ha a szülő újraházasodik. Az elvált szülők gyerekei gyakrabban válnak maguk is, mint a stabil családból származók. A válás okozta trauma feldolgozásához több évre is szüksége lehet a gyerekeknek. (Cseh-Szombathy, 1979)

A fentieken kívül a válás további negatív következménye lehet, hogy a gyerekek korábban hagyják el a szülői házat, fiatalabb korban létesítik az első partnerkapcsolatukat, ugyanakkor tartózkodóbbak, bizalmatlanabbak a házassággal szemben. A csökkenő házasság- kötés ellenére magasabb az elváltak aránya közöttük, mint azon gyermekeknél, ahol a szülök nem váltak el. (Kamarás, 2001.)

A válással a házasság megszünik, de a gyerekek miatt a szülőknek kapcsolatot kell tartaniuk egymással. A gyermekek életét érintő döntéseket közösen kellene meghozni. A gyermekvédelem szempontjából fontos megemlíteni, hogy gyakran a kapcsolattartás nehézségei miatt kerül sor a gyermekjóléti intézmények beavatkozására. A külön élő szülőnek joga van a gyermekkel való kapcsolattartásra, de ez nem mindig zökkenőmentes. Ennek oka lehet egyrészt az, hogy a gyermeket nevelő szülő nem biztosítja a kapcsolattartás lehetőségét, vagy a külön élő szülő nem gyakorolja azt. A válás során sokszor annyira eldurvul a felek kapcsolata, hogy a gyerekeket is egymás ellen használják fel a szülők játszmájukban. Ezekben az esetekben a gyermekjóléti intézmények tudnak segíteni, ahol intézményes keretek között lehetőség van a kapcsolattartásra, a felek közötti közvetítésre.

A jelenkori és a korábbi nemzedékek házassági kapcsolatait összehasonlítva megállapítható, hogy a mai házastársak helyesbíthetőnek értelmezik kapcsolatukat. Ez azt jelenti, hogy a felek érzékelik és érzékeltetik az újraválasztás lehetőségét. A válás után a felek egy része újra házasodik, de egyre kevesebben. (Somlai, 1986)

A 2001. évi népszámlálás adatai azt mutatják, hogy a 10 éves gyermekek több mint egytizede (12,5 százaléka) mostohaszülővel él. Egyre több gyermeknek kell alkalmazkodnia az új partnerekhez, (új házastárs, annak gyermekei). Továbbá át kell alakítaniuk viszonyukat az elköltözött vér szerinti szülővel, esetleg hozzászokni annak új társához és az ő gyermekeihez. 
Míg az egy évesnél fiatalabbak 2,7 százalékára hárul ez a feladat, addig az 5 éveseknek 7,1 százalékára, a 14 éveseknek pedig közel egy tizedére (9,7 százalék). (Spéder, 2006)

Az adatok alapján megállapítható, hogy a válás és az azt követő életesemények jelentős mértékủ alkalmazkodást kívánnak meg a gyerekektől. Azok, akik erre nem képesek, gyakran a gyermekvédelmi intézmények segítségére szorulnak.

A családi kapcsolatok formáját tekintve Magyarországon is jellemzőbbé vált az élettársi kapcsolatok terjedése. A modernizáció nyomán a legtöbb országban jelen van a családszerkezeti változás, az individualizált életformák és az élettársi kapcsolatok terjedése. (Somlai, 1997)

3. táblázat. A házaspáros típusú családok számának alakulása, 1970-2001

\begin{tabular}{|c|c|c|c|c|c|c|c|}
\hline \multirow{3}{*}{ Év } & Összes & $\begin{array}{c}\text { Házaspáros } \\
\text { típusú }\end{array}$ & \multirow{2}{*}{$\begin{array}{c}\text { Ebbő́l: } \\
\text { élettársi } \\
\text { kapcsolat }\end{array}$} & \multicolumn{2}{|c|}{$\begin{array}{c}\text { Az élettársi } \\
\text { kapcsolatok } \\
\text { száma }\end{array}$} & \multicolumn{2}{|c|}{ Élettársi kapcsolatok } \\
\hline & \multicolumn{2}{|c|}{ család } & & az előző & $\begin{array}{l}\text { az } 1970 . \\
\text { évi }\end{array}$ & összes & $\begin{array}{c}\text { házaspáros } \\
\text { típusú }\end{array}$ \\
\hline & \multicolumn{3}{|c|}{ száma (ezerben) } & \multicolumn{2}{|c|}{$\begin{array}{l}\text { adatfelvétel } \\
\text { százalékban }\end{array}$} & \multicolumn{2}{|c|}{ család százalékában } \\
\hline 1970 & 2891 & 2597 & $62^{\text {a) }}$ & - & 100,0 & 2,1 & 2,4 \\
\hline 1980 & 3028 & 2686 & &. & .. & & \\
\hline 1990 & 2896 & 2446 & 125 & .. & 202,6 & 4,3 & 5,1 \\
\hline 2001 & 2869 & 2397 & 272 & 216,6 & 438,9 & 9,5 & 11,3 \\
\hline
\end{tabular}

Forrás: Népszámlálás 2001. 19. Családtípusok, családformák. KSH Budapest. 2004. 17. o.

A 3. táblázat adatai jól illusztrálják, hogy míg 1970-ben a párkapcsolatok 2,4 \%-ra jellemző az együttélés, addig 2001-re a párok 11,3\%-a élt élettársi kapcsolatban. Az élettársi kapcsolatok 1970-hez viszonyítva 2001-re négyszeresére növekedtek. Az adatok alapján megállapítható, hogy a párkapcsolatok átalakulnak. Az élettársi kapcsolatok számának növekedésével párhuzamosan csökkenő tendenciát mutat a házasságkötések száma. Demográfiai kutatások szerint azonban az élettársi kapcsolatok után kötött házasságok jóval bomlékonyabbak, mint azok, amelyeket nem előzött meg együttélés. A párkapcsolatoknak ez a formája sokkal elterjedtebb volt a '60-as években az elváltak és az özvegyek között, mint a hajadonok és a nőtlenek körében. A kilencvenes évek azonban változást hoztak ebben a tekintetben. 1994ben a párkapcsolatban élő nők közül már minden harmadik az élettársi kapcsolatot választotta, 2002-ben pedig a párkapcsolatban élő 20-24 éves nők 46 százaléka. Az élettársi kapcsolat a fiatalok egy része számára a házassághoz vezető út egy lényeges állomása. (Bukodi, 2005) 
Az Ifjúság 2004 kutatás eredményei szerint a 15-29 éves korosztály közel héttizede nőtlen vagy hajadon, 17 százalékuk él házastársi és 14 százalékuk élettársi kapcsolatban. Az Ifjúság 2000 adataihoz képest a nőtlenek/hajadonok arányában lényeges változás nem történt, azonban a tartós kapcsolatban élők összetétele lényegesen megváltozott: 5 százalékponttal csökkent a házastársi kapcsolatot felvállalók, ezzel párhuzamosan ugyanakkor mintegy 7 százalékponttal nőtt az élettársi viszonyban élők aránya. A házasságkötések aránya tehát kétségtelenül csökkent, de ez nem jelenti a tartós kapcsolatok hiányát. Sokkal inkább a tartós párkapcsolatban való együttélés megváltozásáról beszélhetünk. (Bauer-Szabó, 2005)

Az élettársi kapcsolatok terjedésének okai között a strukturális változások közül a felsőfokú képzés expanzióját és az első munkahely megszerzésének bizonytalanságait kell kiemelni. A nem szükségszerüen élethosszig tervezett élettársi kapcsolat az új körülményekhez inkább köthető, mint a tartós elkötelezettséget és anyagi önállóságot is feltételező házasság. Mára az élettársi kapcsolatok társadalmi elfogadottsága is jelentősen javult. (Bukodi, 2004)

\subsection{Iskola}

Az iskola a másodlagos szocializációs színtereként, az elsődleges szocializációs színtért kiegészítve látja el funkcióit. Az iskola funkcionális analízise során 4 fó funkciót különbeztet meg Kozma (1999). Ezek a következők. ,az iskola manifeszt funkcióinak nevezzük a hivatalosan megfogalmazódó igényeket, elvárásokat (akkor is, ha teljesülnek, akkor is, ha nem). Az iskola tényleges funkciói viszont mindazok a szükségletek, amelyeket az iskola kielégít (akár hivatalosak, akár nem).

- az iskola tényleges funkciói viszont mindazok a szükségletek, amelyeket az iskola kielégít (akár hivatalosak, akár nem)

- az iskola latens funkcióinak szokás nevezni azokat a tevékenységeket, amelyekkel az iskola társadalmi környezetének nem hivatalos szükségleteit teljesíti (s emögött természetesen számos nem teljesített, de nem is hivatalos szükséglet lappang);

- míg a nem teljesített szükségletek is árulkodnak az iskoláról, mert akár megfogalmazódtak hivatalosan, akár nem, mindenképpen társadalmi környezet „szívó hatását” mutatják be, amelynek következtében az iskola tevékenységrendszere formálódik." (Kozma, 1999. 292.)

Egy másik felosztás a társadalom szempontjából az iskola funkcióit három csoportra osztja, az elosztó, integráló és adminisztratív funkciókra. Az integráló funkció négy fő elemét a készségek, a személyiség fejlesztése, a tanuló szocializálása, a társadalom kulturális hagyományainak és normáinak átadása, a gyermek, serdülő szerepek körvonalazása és felnőtt szerepek gyakoroltatása alkotja. Ezek a funk- 
ciók minden iskolában megtalálhatók. Ezekre hatással van a tantestület, tanulók társadalmi háttere. (Lambert, Bullock, Milham, 1974)

Az előbbi felosztáshoz hasonlóan az iskolának a társadalmi tapasztalatok, a tudás átadásában betöltött jelentőségét hangsúlyozza Ferge (1976), továbbá az egyéni és a kollektív mobilitás előmozdításában betöltött szerepét, valamint a társadalmi munkamegosztásban való részvételre való felkészítő funkcióját emeli ki.

Az intézményekben élő gyerekek helyzete sajátos a tanulás szempontjából is, mivel ők jelentős hátrányokkal, tanulási lemaradással küzdenek, ami gyakran elörevetíti az iskolai kudarcokat. A tanulásban való lemaradás oka többek között, hogy a család nem tölti be a szocializációs funkcióját, nem teremti meg a tanuláshoz szükséges feltételeket. A szülők egyáltalán nem, vagy csekély mértékben képesek csak a kulturális tőke átadására. A kulturális tőke Bourdieu (1978) felosztásában szereplő tőkefajták egyike, amely a társadalom uralkodó csoportjainak körében elvárt, elfogadott attitüdöket, magatartásformákat foglalja magában. Olyan belsővé vált értékek sorolhatók ide, amelyek a „magas kultúrához” közeliek. Megnyilvánulhat viselkedésben, ízlésben, nyelvhasználatban, speciális készségekben. „a közvetett átadás egy másik formája, amely közvetlenül, de rejtve megy végbe a család és a gyermek között, s amelyet az öröklést szabályozó törvények figyelmen kívül hagynak. Ez pedig nem egyéb, mint a kulturális tőke átadása. (Bourdieu, 1978. 364.) A családból hozott gazdag kulturális tőkével rendelkező gyerekek az iskolában sikeresek lesznek, mert az iskola ezeket a készségeket, képességeket jutalmazza, a hiányát viszont bünteti, miközben nem teszi lehetővé a pótlásukat. A gyermekotthonokba bekerülő gyerekek kevés ilyen készséggel, képességgel rendelkeznek, így a tanulásban nehézségeik vannak.

Az iskolai szocializáció kapcsán meg kell említeni a rejtett tantervet, ami elmaradhatatlan kísérő jelensége a tanítási- tanulási folyamatnak. A rejtett tanterv keretében sajátítják el a gyerekek azokat a tapasztalatokat, ismereteket, viselkedésmódokat, amit az iskola nem tantervszerüen, tantárgyi formában oktat. Ide sorolhatók például az intézményi normák, az illem, az iskolai közösségben való viselkedésre vonatkozó ismeretek, a kortársakkal való kommunikáció. (Szabó, 1988)

Egyes szakemberek a pedagógusok szerepét hangsúlyozzák a probléma kezelésében. Egyéni pedagógusi döntés kérdésévé válik, hogy a hátrányos helyzetü gyermeknek esélyt adnak-e az iskolai közösségbe való beilleszkedésre, a szabályok betartásának megtanulására, hogy pótolni tudják-e legalább részben azokat a szocializációs hiányosságokat, amelyek a családi nevelés során halmozódtak fel. Az iskola szerepe a fiatal későbbi életútjában is meghatározó, az iskolában tapasztalt pedagógusi hozzáállás döntő jelentőségü abból a szempontból, hogy a fiatal hogyan fog viszonyulni a többségi társadalomhoz és a normatív szabályrendszerhez. (Solt, 2007)

Az inklúzív nevelés, az oktatási és a szociális szektor összefogása szükséges a gyermekvédelemben élők iskolai sikereinek javítása érdekében. A gyermekvédel- 
mi gondoskodásban felnövő fiatalok a megszerzett kulturális tőke alapján a társadalom alsó tíz százalékába tagozódnak be, így nagy esélyük van a társadalmi kirekesztődésre. (Varga, 2008)

\subsection{Tömegkommunikáció}

A modern szocializációs környezet tág értelmezésében jelentős szerepet kap a média, mint szocializációs színtér. A XX. század második felében terjedtek el a tömegkommunikációs eszközök, amelyek jelentős hatást gyakorolnak a gyerekekre. Kialakult egy speciálisan a gyerekek igényeihez méretezett kulturális ajánlat, irodalom, képregény, film, színház, tévémüsorok, rádió, lemezek, írott sajtó stb. formájában. (Pukánszky, 2004)

A tömegkommunikációs eszközök közül vezető szerepe van a televíziónak. A média hatására vonatkozó magyarázatok és modellek három nagy csoportot alkotnak. „A direkt hatás modellje azt feltételezi, hogy a média „mindenható”, azaz tömegkommunikáció szinte közvetlen és azonnali változást tud elérni. Noha a kutatások zöme a „mindenható médiával” szemben mára már messze komplexebb modellben írja le a szimbolikus kommunikáció és az arra adott emberi válaszviselkedés közötti kapcsolatot, mint azt a kezdeti, direkt inger-válasz feltételezések tették, a közfelfogás még ma is hajlik a média erejét ilyen közvetlen, egyirányú, ok-okozati összefüggésben látni.

A korlátozott hatás modellje szerint a tömegkommunikáció nem rendelkezik olyan hatóerővel, hogy alapvető befolyást gyakoroljon a befogadóra. Fő ereje abban van - vélik ezen álláspont hívei -, hogy a már meglévő véleményeket, értékek és beállítódásokat (attitüdöket) megerősíti.

Újabban a média hatását a fenti két modell elképzelésénél bonyolultabb összefüggésben írják le. E harmadik modell hangsúlya arra tevődik, hogy a média meghatározott feltételek esetén rendelkezik erőteljes befolyásoló erővel. E feltételek lehetnek egy adott embercsoport (pl. férfiak, nők, idősek, fiatalok, egy kisebbségi csoport stb.) különleges sajátosságai, aktuális események, különleges feltételek.

A három felfogás között a következő különbségek vannak. A direkt hatás modellje szerint minden befogadóra nagy, (akár 100 \%-os) befolyást gyakorol a média. A második, a korlátozott hatás nézete szerint minden befogadóra gyenge (csak például 20-30 \%-os) a hatás. A harmadik elképzelés, a „meghatározott feltételek esetén érvényesülö direkt hatás modellje" szerint a befogadók egy csoportjára (mondjuk a médiafogyasztók 20-25\%-ára vagy az üzletemberek egy csoportjára vagy magányos nőkre vagy a gyerekekre) meghatározott feltételek között a hatás akár $100 \%$-os is lehet. Így lehetnek, akikre a média aktuális üzenete nagyon nagy hatást gyakorol, míg esetleg a befogadóknak akár többségére az adott üzenet semmilyen befolyással nem lesz." (Vajda, Kósa 2004. 376.) 
A média alapvetően befolyásolja a szabadidő eltöltését, ezt mutatja az Ifjúság 2004 kutatás eredménye is, amelyekből az derül ki, hogy a 15-29 éves korosztály jelentős mennyiségű időt tölt tévézéssel, hétvégén több mint 3 órát.

4. táblázat. Tévénézésre forditott áltagos napi idő hétköznap és hétvégén korcsoportonként, 2004-2008

\begin{tabular}{|c|c|c|c|c|}
\cline { 2 - 5 } \multicolumn{1}{c|}{} & \multicolumn{2}{c|}{2004} & \multicolumn{2}{c|}{2008} \\
\hline Korcsoport & Hétköznap & Hétvégén & Hétköznap & Hétvégén \\
\hline $\mathbf{1 5 - 1 9}$ & 143 & 235 & 107 & 181 \\
\hline $\mathbf{2 0 - 2 4}$ & 134 & 208 & 105 & 174 \\
\hline $\mathbf{2 5 - 2 9}$ & 130 & 202 & 104 & 168 \\
\hline
\end{tabular}

Forrás: Szabó-Bauer (szerk.) Ifjúság 2008 Gyorsjelentés 88. o.

A 4. számú táblázat adatai szerint 2004 és 2008 között csökkent a tévénézésre fordított átlagos idő, mind hétköznapokon, mind pedig a hétvégeken. Ez elsősorban az internet térhódításának és a napi szintű médiafogyasztásba való beépülésének köszönhető. A televízión megspórolt időt a számítógép és az internet vette át. (Szabó- Bauer, 2008)

A televízió szocializációs szerepe nyilvánvaló, ha csak a tévézésre fordított idő mennyiségére gondolunk. Nemcsak mint a szórakozás eszköze funkcionál, hanem szocializációs ereje abban is megnyilvánul, hogy a serdülők jelentős része szerepmodelljeit, példaképeit, azokat a karaktereket, akikhez hasonlóvá szeretnének válni, a televízió uniformizált világában találják meg. A televízió így nemcsak jelentős szocializációs ágens, hanem egyfajta globalizáló szocializációs erőnek is tekinthető. (Vajda, Kósa, 2004)

\subsection{Kortársak}

A szocializáció egyik legfontosabb spontán ágense a kortárscsoport. Ez fontos szerepet tölt be a gyerekek életében, akik jelentős mennyiségü időt töltenek társaikkal a különböző oktatási intézményekben. A gyermekvédelmi intézményben élők körében még jelentősebb a kortársak szerepe, mivel ők az iskolán kívüli idő jó részét is társaik körében töltik. Ezzel szemben a családban élők ennek az időnek legalább egy részét családtagjaikkal töltik.

A kortársak között szerzett tapasztalatok jelentősége is abban áll, hogy előkészítenek a felnőtt szerepre, például a másik nemmel való érintkezés szabályozá- 
sával, a viselet, a díszítés sztenderdjeinek az elfogadtatásával, a megszólítási és egyéb kommunikációs módok, beszélgetési témák, illetve a testmozgás, arcjáték és más nem verbális eszközök alkalmazásának kiválasztásával, a találkozási alkalmak kezdeményezésének és fogadásának elsajátításával. (Somlai, 1997)

A gyerekek viselkedésére 6-8 éves kortól gyakorolnak jelentős hatást a kortársak. Óvodáskorban még kevésbé jellemzi őket a baráti kapcsolat, az elmélyült barátságok kialakulása serdülőkorra tehető. A serdülőkor kezdetétől fogva a barátság két legfontosabb tényezője az egymással szembeni lojalitás, a kölcsönös megértés és az intimitás. A kortárs hatások szerepe ettől kezdve sok kérdésben egyenértékü a felnőtt hatásokéval, vagy erősebb is lehet. (Vajda-Kósa 2004)

A gyermekek kortárskapcsolatai segíthetik a beilleszkedésüket egy új környezetbe. A gyermekek lokális kortárskapcsolatainak fontos szocializációs és szociálintegratív funkciói vannak. (Pataki, 1977) Ez a funkció jelenik meg az intézményben élő gyerekek körében, amikor testvéreikkel együtt kerülnek elhelyezésre. A testvérek egymást erősítve segítik az új környezetbe való beilleszkedést. Ezért is hangsúlyozzák a szakemberek a testvérek egy intézményben való elhelyezésének fontosságát.

A kortárskapcsolatok alakulását az intézményben élő gyerekek esetében befolyásolja többek között, hogy milyen életkorban kerültek az intézménybe, mennyi ideje tartózkodnak ott, milyen a csoport összetétele, amelyben élnek. Lényeges, hogy sor került-e intézményváltásra az elhelyezésük során. Az intézményekben, csoportokba szervezve helyezik el a gyerekeket, így a csoportképződés, a csoporthatások felértékelődnek. Itt sajátítják el a gyerekek a szociális viselkedést, az együttélés szabályait, a normákat. Különösen fontos a csoportképződés serdülökorban az identitás formálódása szempontjából. A csoport sajátos funkcionális kvalitással bír, ami a csoporttagok között levő kölcsönhatás és kommunikáció, azaz egymás kölcsönös befolyásolása alapján alakul ki. (Pikó, 2005)

A kortársi szocializáció pozitív és negatív hatással is lehet a gyerekekre. A pozitív hatások közé tartozik, hogy elősegíti a szociális kompetencia fejlődését, támaszt nyújt az egyén számára, érzelmi biztonságot ad a fenyegető helyzetben, lehetőséget ad az irányító szerep kipróbálására, a valahova tartozás érzését adja. (Asher, Parker, 1989)

A negatív hatásokat a szakemberek elsősorban abban látják, hogy a kortársak jelentősen befolyásolják különösen a fiatalkori alkohol-, drogfogyasztást, valamint más devianciák kialakulását. (Pikó, 2005, Elekes-Paksi, 2005)

\subsection{A gyermekvédelmi intézmény, mint speciális szocializációs színtér}

A szakirodalom nem nevesíti külön szocializációs színtérként a gyermekjóléti, gyermekvédelmi intézményeket. Ez érthető, hiszen az intézményekbe csak a gyerekek meghatározott, kisebb csoportja -2005-ben 16671 fö- kerül. Mégis fontos kiemelni 
a gyermekvédelmi intézmények helyettesítő védelmet biztosító, szocializáló szerepét, igaz itt sajátos körülmények között valósul meg ez a funkció. Az intézmények próbálják megoldani a család helyettesítését, lehetőséget adnak a kortárskapcsolatok kialakítására és hosszú időn keresztül a gyerekek oktatását is a belső iskolákban biztosították. Így sokféle szocializációs színtér feladatát látták el egy helyen. Szocializációs közegeknek minősülnek azok a csoportok vagy társadalmi helyzetek, amelyekben a szocializáció alapvető folyamatai végbemennek. (Giddens, 1997) Véleményünk szerint ebben az értelmezésben egy sajátos szocializációs színtérnek tekinthetők a gyermekvédelmi intézmények: a gyermekotthonok, lakásotthonok.

A bentlakásos intézmény, mint nevelési színtér jelentős szerepet tölt be a gyermekek szocializációjában. Ezen intézmények közé tartoznak a kollégiumok mellett a gyermekotthonok és lakásotthonok is, amelyeknek különböző funkcióik vannak. Gilligani (1999) felosztásában a gyermekotthonok négy funkcióját,

- a gondoskodást,

- a védelmet,

- a kompenzációt

- elökészítést különbözteti meg.

A gondoskodás keretében az alapvető fizikai és pszichoszociális, érzelmi szükségleteket elégítik ki, a gyerek életkorának megfelelően. A védelem azt jelenti, hogy az intézménybe kerülö gyereket veszélyeztető tényezőket megszüntetik, a veszélyekkel szemben védelmet biztosítanak számára, valamint pozitív célokat tüznek ki elé. A következö funkció a kompenzáció, amelynek keretében a gyerek életében felmerülö hiányosságokat az intézmény igyekszik kompenzálni. Ez egyrészt az oktatási, egészségügyi szolgáltatások igénybevételét jelenti, másrészt olyan speciális terápiákat, amelyekkel segítenek feldolgozni a gyereket ért traumákat, oldják a poszttraumás stresszt. A negyedik funkció az előkészítés. A gyereket fel kell készíteni az önálló életre a praktikus ismeretek elsajátításával. Az előkészítés funkciója jelenti továbbá a családba való visszahelyezés, a társadalomba való beilleszkedés segítését is. (Gilligani, 1999)

A gyermekotthonok védelmező funkcióját Emiliani és Bastianoni (1993) az elöbbiekhez hasonlóan abban látja, hogy a gyereket ért veszélyeztető tényezőket megszünteti, csökkenti a stressz ártalmakat.

A gyerek kedvezötlen helyzetének megszüntetése mellett az otthon támogatja a fejlődésbeli lemaradás korrekcióját. Segíti az iskolai tanulmányok teljesítését, fejleszti a gyerek önértékelését, önbecsülését. Az intézmény lehetővé teszi az új társas kapcsolatok kialakítását, ezzel is fejleszti a gyerek személyiségét, a közösségen belül a pozitív légkör kialakítását.

A bentlakásos intézmények közé sorolhatóak a kollégiumok is, amelyeknek szintén több funkciója van. A szocializációs funkció, ami az értékek, közösségi hagyományok átörökítését szolgálja. Az életmód, mintaadó funkció, a felzárkóztató, tehetséggondozó és a pályaorientációs funkció. A felzárkóztató funkció azt jelenti, 
hogy a kollégium mind az egyes iskolák színvonalbeli különbségeiből, mind a növendékek személyiségfejlődésének különbségeiből adódó hátrányos helyzeteket mérsékli. A tehetséggondozó funkció keretében foglalkoznak a kiemelkedő képességü tanulókkal. A továbbtanulási és munkaerőpiaci trendek folyamatos figyelésével, méréses módszerek alkalmazásával, a tanulók önismeretének fejlesztése révén teljesítik a pályaorientációs funkciót. (Benedek, 1997)

A gyermekotthonok, lakásotthonok a kollégiumokhoz hasonló funkciókat töltenek be, de ezek teljesítésében több sajátosságot mutatnak a kollégiumokhoz képest. A gyermekotthonokban, lakásotthonokban fontos szerep jut az életmódmintának. A gyermekotthoni nevelés legfőbb sajátossága, hogy a gyermekotthon veszi át részben a család szociálpszichológiai értelemben vett státusát, szerepeit, szocializációs feladatait. (Domszky, 1999).

Az életmód formálása és a szocializáció egymással szorosan összekapcsolódik, mivel az életmód alakulására az emberek legkorábbi szocializációs élményei hatnak, a legelső kondicionálások sora, az először tapasztalt feltételek és minták. Az életmód ugyanakkor változhat is az ember élete során. A folyamatosság vagy a diszkontinuitás, a folyamatok megtörése az életmódváltozásokban kísérhető figyelemmel. (Losonczi, 1977)

A gyerekek önálló életre való felkészítése is az intézmények feladata, amit részben az életmódminták adásával valósítanak meg. A kiscsoportos -legfeljebb 12 fö- elhelyezését biztosító lakásotthonokban ez könnyebben megvalósítható, mint a korábbi években a nagy létszámú otthonokban. Kiemelt szerep jut a nevelőnek a mintaadásban, mivel ö maga is modell a gyerekek számára.

A felzárkóztató funkció itt kiemelt jelentőséggel bír, mivel az intézményekbe jelentős tanulmányi és szocializációs hátrányokkal kerülnek be gyerekek. Az intézmények feladata ezeknek a hátrányoknak a mérséklése, amit a gyerekek iskolázottságára vonatkozó kutatások eredményei szerint kevéssé sikerül megvalósítani. (Veres-Brezovszky, 1990, Hazainé-Csókay, 1990, Varga, 2008, Hodosán-Rácz 2009). A hátrányok kompenzálásához különböző szakembereket, pedagógusokat, pszichológusokat alkalmaznak az intézmények.

Ezek a szakemberek látják el a tehetséges gyerekek gondozását is. Figyelemmel kísérik és segítik tanulmányi előrehaladásukat, a pályaválasztást.

A szabadidős funkciót az intézmények különböző rekreációs programokkal próbálják megvalósítani. A gyerekeknek és fiataloknak meg kell tanulniuk, hogy fontos az ember fizikai, lelki és szellemi erejének a megújítása a fáradtság, érzelmi megterhelések, a fizikai és szellemi erők kimerülése után. Különösen igaz ez a stressz és a megterhelő élethelyzetek elviselésekor. (Domszky, 1999)

A gyermekotthonok, lakásotthonok funkciói közé tartozik a reszocializáció is. Bár elsősorban a javító-nevelő intézetek feladata a reszocializáció megvalósítása, de a lakásotthonokban, gyermekotthonokban élő gyerekek körében is előforduló antiszociális magatartás miatt ezeknek az intézményeknek is van ilyen jellegü fel- 
adata. A fiatalkorúak reszocializációja komplex és speciális nevelési (fejlesztési) folyamat keretében valósul meg. Célja az antiszociális fejlődésirányú és/vagy bünelkövető fiatalok speciális szükségleteinek (szociális, nevelési-oktatási, mentálhigiénés, egészségügyi) teljes körü és/vagy célszerü kielégítése által szocializáltsági szintjük javítása, s ezen keresztül társadalmi integrációjuk/ reintegrációjuk esélyeinek növelése. (Volentics, 1996)

A szocializációs funkciót, annak sajátosságait részletesen a következőkben tekintjük át. Az intézményekben a szocializációt befolyásolja többek között a gyerek korábbi életkörülménye, tapasztalata, az, hogy milyen életkorban került ki a családjából. A család intim légkörét nem tudja pótolni az intézmény, de a kiscsoportos lakásotthoni nevelés során erős a törekvés a családias körülmények biztosítására.

A családi otthon modellként való megvalósítását funkcionális családmodellnek nevezik. A lakásotthonok múködésnek egyik alapelve az, hogy ha egy gyerek - különböző körülmények miatt- nem nevelkedhet a családjában, akkor olyan életmódot kell felkínálni neki, amely a normál életkerethez a legközelebb van, és leginkább megfelel annak az életformának, amelyben a családok élnek. (Ligthart, 1986)

Az intézményekben fontos az otthonosság feltételeinek a biztosítása. Ez elsősorban a családszerü kiscsoportok létesítését jelenti, a központi szolgáltatások célszerü összekapcsolásával. Olyan csoportminőséget igyekeznek elérni, melyet az intimitás, a viszonyok áttekinthetősége, a kommunikáció sürúsége, a stabilitás, a csoport elkötelezettség, az együttmüködés és a nyíltság jellemez, ami kifejeződik a csoporton belüli és kifelé irányuló interakciókban. (Zrinszky, 2002) A kiscsoportos lakásotthonokban az otthonosság elvének a megvalósulása, az ehhez szükséges feltételek biztosítása nagyobb hangsúlyt kap, mint a korábban múködő nagy létszámú intézményekben. Ez abban nyilvánul meg, hogy az egyes lakásotthonok sajátos arculattal rendelkeznek, jóval kevesebben, 2-3 fö kerül egy szobában elhelyezésre, így nagyobb önálló élettérrel rendelkeznek a gyerekek. Továbbá az otthonosságot biztosítja az is, hogy a növendékek maguk is részt vesznek a háztartási teendők ellátásában, az otthon rendjének fenntartásában, a családi életre való felkészülésben.

E mellett az intézmények feladata a családokkal való kapcsolattartás segítése, az ehhez szükséges feltételek megteremtése. Ez jelentheti a család, a hozzátartozó látogatását vagy a gyerek hazalátogatását. A szülőkkel való együttmüködés fontos a gyermek intézményes szocializációja során is. A gyermekotthoni nevelés során az intézmény és a szülők együttes és megosztott felelősséget vállalnak magukra. A szülőket a speciális körülmények között meg kell tanítani a gyerekük iránti felelősség vállalására. A családi környezet több-kevesebb erővel még akkor is érzékelteti hatását, mikor a gyermekotthoni tartózkodás alatt a család a fiatalt nem nevelheti. (Ploeg, 1986)

Az intézményes elhelyezés során fontos alapelv, hogy minél rövidebb legyen az itt töltött idő. Ennek megvalósításához is szükséges a családdal való kapcsolattartás, valamint a család felkészítése a gyerek visszafogadására. Holland kutatók 
úgy találták, hogy a tartózkodási idő és a problémák között U görbe jellegü összefüggés áll fenn, vagyis az intézményekbe való bekerülés után egy meghatározott ideig csökkennek a problémák, majd ismét sokasodnak. A nevelőotthoni kezelés hatása elér egy meghatározott felső értéket, ezután már nem fejt ki hatást, és bizonyos problémák, konfliktusok újra jelentkeznek. (Ploeg, 1986)

Megállapítható, hogy az intézmények feladata összetett, mert mind a gyermek szocializációját, mind a szülők segítését, a gyermek nevelésére alkalmassá tételét is segíteniük kell. Abban az esetben, ha nem sikerül a család gondozásával a gyereket visszahelyezni a családba, a fiatal 21 éves koráig intézményes keretek között maradhat. Erre lehetőséget ad az utógondozói ellátás. Így az intézményeknek komoly szerep jut a 18-21 éves életkori szakaszban, szocializációban: az önálló, felnőtt életre való felkészítésben. A gyermekvédelmi intézmények szocializációs funkciója tehát nemcsak a gyermekeket, de a fiatal felnőtteket is érintheti. Az intézményben megvalósuló szocializáció pedig alapvetően meghatározza a fiatalok társadalmi beilleszkedését.

Az intézmény szocializációs funkcióját befolyásolja az intézmény elhelyezkedése, nyitottsága. A korábbi nevelőotthonokban jellemző volt az intézményi zártság, a külső kapcsolatok hiánya. Az otthonok átalakulásával, a belső iskolák megszünésével a szocializációs funkció teljesebbé vált. A gyerekek sokkal inkább megismerik az őket körülvevő világot, gazdagabb társas kapcsolatot tudnak kialakítani a kortársakkal, a szomszédsággal, a helyi lakókörnyezettel, mint korábban a zárt intézményekben.

\section{1. ábra. Bronfenbrenner ökológiai modellje}

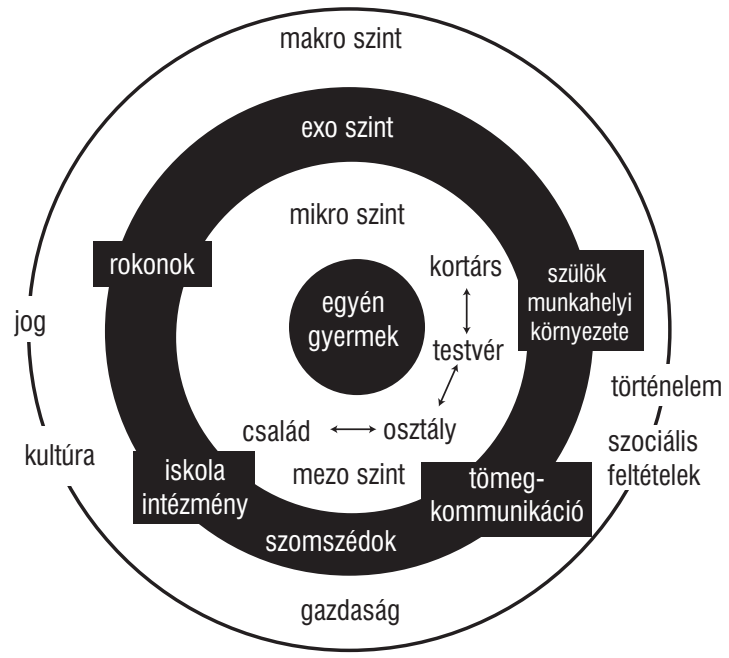

Bronfenbrenner, 1992 
A szocializáció folyamatát rendszerelméleti megközelítésben elemezte Bronfenbrenner a '90-es években. Ökológiai modelljében mikro-, mezo-, exo-, és makrorendszert különböztet meg. Az elmélet szerint az egyén és az őt körülvevő környezet rendszert alkot, aminek különböző szintjei vannak. Az egyes szintek koncentrikus köröket alkotva egymásra épülnek, az egyes szintek hatással vannak az őket követő szintekre, kölcsönös összefüggés van közöttük. Az első a mikrorendszer, amely magában foglalja a gyereket és az öt körülvevő közvetlen környezetet. Ez egyrészt jelenti a tárgyi környezetet, másrészt azokat az interperszonális kapcsolatokat, szabályokat, szerepeket, amelyekkel a gyermek kapcsolatba kerül. A gyerek fejlődése szempontjából ezen a szinten kiemelt jelentősége van az anya-gyermek kapcsolatnak. Az anya-gyermek kapcsolat jelentőségére több fejlődéslélektani kutatás is felhívta a figyelmet. A mezorendszer két vagy több további színtér megjelenését jelenti a gyerek életében, amiben fejlődik a személyisége, aktivitása. Ilyen színtér a bölcsőde, óvoda, iskola, ami egyben a másodlagos szocializáció színtereként, hatással van a mikrorendszer müködésére és viszont.

A exorendszer két vagy több olyan színteret jelent, aminek a működése hatással van a gyermek fejlődésére, de a gyerek ebben aktívan nincs jelen. Ilyen lehet például az anya munkahelyi elfoglaltsága. A makrorendszer magába foglalja a kultúrát, szubkultúrát, a szociális, gazdasági, politikai rendszereket. A makrorendszer tartalmazza továbbá azokat az életlehetőségeket, szociális kontextusokat, amelyek az adott társadalomban elérhetőek. (Bronfenbrenner, 1992)

A fentiekben bemutatott ökológiai modell keretet ad a gyermekvédelmi intézményekben végbemenő szocializációs folyamatok értelmezéséhez. Erről kevés kutatás áll rendelkezésre. Kevés ismeretünk van az ott alkalmazott probléma megoldási módokról is, az alkalmazott eszközökről és ezek hatásáról. Több szerző ezért az intézményes szocializáció folyamatát „black box” jelenségnek nevezi. (Ploeg, 1986, L. Palareti, C. Berti, 2009)

Bronfenbrenner ökológiai modelljét a gyermekotthonok, lakásotthonok müködésének értékeléséhez is felhasználta kutatása során (L. Palareti-C. Berti, 2009). A modell alkalmazását többek között az indokolja, hogy a folyamatok megvalósulása nemcsak a dolgozók közvetlen tevékenységén múlik, hanem a környezeti rendszerek közötti dinamikus kapcsolat is befolyásolja. Így például a gyerek fejlódése nemcsak az őt gondozó személyzettől függ, hanem azoktól a lehetőségektől is, amelyeket az ellátórendszer biztosít.

A gyermekvédelmi intézményekben mikrorendszerben értelmezhető a gyerek és az őt nevelő felnőtt kapcsolatának minősége, annak a közösségnek a légköre, amelyben a gyerek elhelyezésre került. Meghatározó eleme ennek a szintnek továbbá a mindennapokban alkalmazott napirend, az intézményi szabályok, rituálék. A gyereket közvetlenül körülvevő fizikai környezetet is jelenti ez a szint, amely abban az esetben segítheti a gyerek szocializációját, ha az otthonosság elve szerint szervezik. Az interperszonális kapcsolatokban a felnőttekkel való kapcsolat 
minősége mellett fontos a gyerektársakkal való kapcsolat is. A felnőttekkel való kapcsolat minősége és a napirend a legfontosabb tényezők, amik megváltoztathatják a gondozásba kerülö gyereket, ezek minősége hatással van a közösségen belül kialakuló légkörre is.

A mezorendszerhez sorolható a gyereket körülvevő közösség, az iskola, az intézmények által szervezett szabadidős lehetőségek. A rendszerben fontos szerepet kap a különbözö intézmények közötti folyamatos együttmüködés, a gyerek elhelyezési helyének állandósága. Ezen a szinten jelenik meg a gondozási terv, ami minden gyermek számára elkészül és folyamatosan bővítik. A gondozási terv megteremti a kapcsolatot a múltbeli és a jelenlegi ellátás között, valamint eszközül szolgál a gyerek jelenlegi és jövőbeni szükségleteinek kielégítéséhez.

Az exorendszer az intézmény más intézményekkel, személyekkel való kapcsolatrendszerét jelenti, akik foglalkoztak a gyerekkel és a családjával. A rendszer sajátossága, hogy közvetlenül nincs jelen a gyerek, de ennek a szintnek a történései hatnak rá. Itt jelenik meg többek között az intézmény vezetésének munkája, az intézmények közötti információcsere, annak a hálózatnak a müködése, ami azért jött létre, hogy koordinálja az egyes szereplők közötti együttműködést.

A makrorendszer tartalmazza a beavatkozások/ a segítés szociokulturális öszszefüggéseit. Azokat az explicit és implicit elméleteket, amelyek a beavatkozás alapját képezik az adott társadalomban. Ezen a szinten jelennek meg a beavatkozás eredményességét segítő terápiás lehetőségek, nevelési módszerek. Ide tartoznak még az intézmények működését meghatározó szabályok, törvények, folyamatok, az intézményi ellátórendszerek. (L. Palareti-C. Berti, 2009)

A fejezetben áttekintettük a szocializációs színtereket, részletesebben a gyermek-otthonokat, lakásotthonokat, azok funkcióit mutattuk be. Az intézmények funkcióit többféle megközelítésből szemlélve megállapítható, hogy elsősorban a szocializáció, a védelem, a kompenzálás és az önálló életre való felkészítés a fö feladatuk. Ezeknek a feladatoknak a teljesítése befolyásolja az intézményben élő gyerekek életkörülményeit, nemcsak az intézményben töltött idő alatt, hanem a későbbiekben is. Az önálló életre való felkészítés és a társadalomba való beilleszkedés sikeressége elsősorban az intézményből való kikerülés után mutatkozik meg. A szocializációs színterek áttekintése után megállapítható, hogy a különböző színterek közötti együttmüködés javítása szintén segítheti a gyerekek önálló életre való felkészítését, javíthatja életkörülményeiket. Kiemelten fontos lenne többek között a család és az otthonok, az iskola és az otthonok, az iskola és a család intenzívebb együttmüködése. Ezt erősíti meg Bronfenbrenner (1992) ökológiai modellje is, amelynek alkalmazása segíti az intézményes elhelyezés értékelését, és azoknak a beavatkozási irányoknak a kijelölését, amelyekkel hatékonyabbá tehető az intézményes nevelés, valamint javíthatók a gyerekek életkörülményei. 


\section{A GYERMEKVÉDELEM EURÓPÁBAN - NEMZETKÖZI KITEKINTÉS}

A fejezetben a nyugat-európai országok és a kelet-közép-európai országok gyermekvédelmének elemzésére vállalkozunk. Arra a kérdésre keressük a választ, milyen sajátosságokat mutat az egyes országokban a gyermekek intézményes elhelyezése. Kérdésként merül fel, hogy mennyiben foglalhatók modellekbe az egyes országok, és milyen közös vonások jellemzik a gyermekvédelmi rendszereket. Az összehasonlító elemzés során legfontosabb szempont annak vizsgálata, hogy milyen elhelyezési lehetőségeket - ezen keresztül milyen életkörülményeket- biztosítanak az egyes országokban a család nélkül felnövő gyerekek számára.

Az európai országokban általában a korábbi évszázadokban kialakult a gyermekvédelem valamilyen formája. Az egyes országok gyermekvédelmének öszszehasonlításában nehézséget jelent, hogy az ellátások alakulását erőteljesen meghatározza az adott ország, régió társadalmi, gazdasági és kulturális háttere. A témában használt fogalmak eltérőek, a különböző országok különböző terminusokat alkalmaznak ugyanazokra a jelenségekre. Ezen okok miatt a gyermekvédelem nemzetközi összehasonlítása nehéz feladat. A feltett kérdések megválaszolását nehezítette, hogy a témában csekély számú szakirodalom áll rendelkezésre. Kevés nemzetközi összehasonlító vizsgálat készült az előbbiekben felsorolt okok miatt. Különösen igaz ez a kelet-közép-európai országokra, amelyeknek a bemutatásához jórészt csak angol nyelvü irodalomra és az UNICEF Innocenti Research Center angol nyelven megjelent kutatási eredményeire hagyatkozhattunk. Ez az oka annak, hogy a kelet-közép-európai országok gyermekvédelmi rendszerének elemzése terjedelmi szempontból kissé elmarad a nyugat-európai országokhoz képest.

A gyermekek korát, nemét, a gyermekotthon méretét, a gyermekek elhelyezésének okait, az ellátás minőségét vizsgálva három modellbe sorolhatók az európai országok. Az 1. modellbe a dél-kelet-európai országok sorolhatók, így Albánia, Törökország, Szerbia-Montenegro, Bosznia-Herczegovina, Örményország, Azerbajdzsán és Grúzia. Ezekben az országokban a gyermekotthoni elhelyezés aránya alacsony, de sok hasonlóságot mutat a közép-kelet-európai országok gyermekvédelmével. A hasonlóság abban nyilvánul meg, hogy itt is elsősorban nagy létszámú intézményekben kerülnek elhelyezésre a gyerekek. Ezekben az országokban magas arányú a csecsemők intézetekben való elhelyezése. Az elhelyezés időtartama hosszú, 5 év, vagy annál is több. A gyermekek elsősorban családi krízis, gyermekbántalmazás és szegénység miatt kerülnek az intézményekbe.

A második modellt a közép-kelet- európai országok alkotják. Ebben a régióban (Bulgária, Oroszország, Románia, Lengyelország, Magyarország, Lettor- 
szág, Észtország) jellemző, hogy magas a gyermekotthonokban élő gyermekek aránya, miközben az intézeti körülmények nem korszerüek. A nagy létszámú otthonokban nem gyerekbarát a közeg. Ma is müködnek ilyen nagy létszámú otthonok ebben a régióban, ahol intézményenként 100-300 gyerek elhelyezésére kerül sor. Jellemző az is, hogy elsősorban „szociális árvák” elhelyezésére kerül sor. Ez azt jelenti, hogy a gyerekeknek legalább az egyik szülöje él. Az elhelyezés oka a rossz szociális, gazdasági körülményekben keresendő. További problémát jelent, hogy a régióban magas a csecsemőotthonokban élő gyermekek aránya is. A közép-kelet-európai országok a gyermekek helyzetének javítása érdekében irányelveket dolgoztak ki és intézkedéseket foganatosítottak a rendszerváltás után. Néhány tekintetben jelentős változás figyelhető meg ezekben az országokban. A gyermekotthoni elhelyezések száma csökkenő tendenciát mutat például Romániában. Szerkezeti müködési szempontból átalakulás tapasztalható, Oroszországban és Szlovákiában. A csecsemőotthonok száma csökken Magyarországon és Észtországban. A gazdasági problémák, a rossz szociális helyzet miatt nő a gondoskodásra szoruló gyermekek száma. Különösen igaz ez Oroszországra, ahol az elhelyezett gyermekek száma 1990-ben 49.000 fó volt, ami 2000-re 123.000-re emelkedett. Radikálisan növekedett a 0-3 éves korúak csecsemőotthoni elhelyezésének száma Oroszországban.

A harmadik modellbe a „gazdag” európai országok tartoznak. Jelentős különbség figyelhető meg a régión belül az észak-európai és a dél-európai országok között. Az Egyesült- Királyságban, Norvégiában és Izlandon 1000 gyermekből 1 vagy kevesebb él gyermekotthonban. Dániában, Németországban, Franciaországban, Portugáliában a gyermekotthonban élők aránya 5-7 ezrelék. Svédországban, Finnországban, Írországban, Belgiumban, Hollandiában, Olaszországban, Spanyolországban ez az érték 1,5-3 ezrelék között mozog. (Gudbrandsson, 2004)

Mint korábban jeleztük, az egyes országokban a gyerekek elhelyezési lehetőségeit nehéz összehasonlítani, mert nagymértékben eltér az intézményi környezet és nincs egységes értelmezés sem. A következőkben a nyugat-európai és a kelet-közép európai országok gyermekvédelmét mutatjuk be. Az egyes országok modellt alkotnak abból a szempontból, hogy mikor és hogyan valósult meg a gyermekvédelem intézményesülésének folyamata. A gyermekvédelem fejlődésére jelentős hatást gyakorolt az, hogy 1945 után két eltérő, egymással versengő világrendszer jött létre. A nyugat-európai országok demokratikus müködése, a jóléti állam létrejötte jelentős hatással volt a gyermekvédelemre.

Ezzel szemben a kelet-közép- európai országok diktatórikus müködése más irányt szabott a gyermekvédelmi rendszer müködésének. Itt később következett be az intézményesülés, elötérbe került az un. közösségi nevelés és ennek megfelelően a nagy otthonok létrehozása. A rendszerváltás utáni években azonban a kelet-közép-európai országok is újragondolták a gyermekvédelmi ellátórendszerüket, és a nyugat-európai tapasztalatokat is felhasználva jelentősen megváltoztatták a gyere- 
kek elhelyezési lehetőségeit. A dolgozat következő részében ezt a kétféle fejlődési modellt mutatjuk be.

\subsection{A nyugat-európai országok gyermekvédelme}

Németországban a második világháború utáni időszak új fejezetet nyitott a gyermekvédelmi intézmények életében. A gyermekvédelem sajátosan alakult a különvált Német Demokratikus Köztársaságban. Itt elsősorban a szocialista nevelésnek rendelték alá a gyermekvédelmet. A nevelőotthonok, ifjúsági hivatalok a közoktatáshoz tartoztak. A gyerekek nagy létszámú nevelőotthonokba kerültek, ahol a közösségi nevelés került előtérbe. Hasonló folyamatok zajlottak le a többi középkelet-európai országban is, erre a fejezetben később térünk ki. (Trede, 1993)

Németország nyugati felében a '60-as évek végéig a meghatározó gyermekvédelmi intézkedés, a gyerekek családból való kiemelése és a nevelőotthoni elhelyezés volt. Az 1968-as diákmozgalom idején követelték a diákok a nevelöotthonok reformját is, miközben nevelőotthon-ellenes kampányt is folytattak. Követelték, hogy nyissák meg az otthonokat, a fiataloknak pedig legyen joguk beleszólni az öket érintő döntésekbe. Ennek a nyomásnak is köszönhető, hogy jelentős változások következtek be a gyermekvédelmi intézményekben, megszüntek a nagy intézmények. Különböző kisebb családias jellegü lakásotthonok jöttek létre. Megerősítették a napközbeni ellátást, illetve a gyerekek családban való nevelését segítő szolgáltatásokat vezettek be. A 70-es évek reformjainak másik súlypontja -a nevelőotthoni nevelés demokratizálásán túl- az intézményes formák önállósodása volt. Ha már a meglévő „kaszárnyákat” nem darabolhatták fel, akkor legalább a csoportokat szervezték más módon: kisebb létszámmal, áttekinthető, viszonylag önállóan gazdálkodó egységekké alakították őket és ezzel párhuzamosan 8-15 férőhelyes kis otthonok keletkeztek. (Trede, 1993.)

A gazdasági-pénzügyi kényszer révén az otthonok nagy része a '80-as években igen jelentős átalakuláson ment át. Nagy részük szociálpedagógiai központtá vált. Ez azt jelentette, hogy egyrészt a gyermek problémája került a tevékenység középpontjába, másrészt a társadalmi környezettel való kapcsolatok erösítése, különösen a szülökkel való kapcsolat rendezése.

A családból kiemelt gyermek nevelőszülőhöz vagy nevelőotthonba kerül. 2005ben 21.052.000 gyermek élt Németországban. Közülük 61806 fö gyermekotthonokban, 50364 fö pedig nevelőszülőknél került elhelyezésre. A 2005. és a 2007. évi adatok összevetésével állapítható meg egyértelmüen a nevelőszülöi elhelyezésre való törekvés megvalósulása. 2007-ben ugyanis 52793 fó élt gyermekotthonban, 49673 fö pedig nevelöszülöknél. (Statistiches Bundesamt Deutschland, 2005.)

A nevelőotthon elveszítette monopolhelyzetét a családjukból kiemelt gyermekek nevelésében, alternatívaként egyre inkább nevelőszülőknél helyezték el a gyermekeket. Ezzel egyidejűleg pedig a szakszerủ megelőzés számos ellátási formája jött létre. (Trede, 1993) 
A gyerekek elhelyezését az Ifjúsági Hivatal szervezi, gyakorolja a nevelési felügyeleti jogot, valamint az engedélye is szükséges a gyerek befogadásához. A Hivatal munkatársai ellenőrzik az elhelyezés körülményeit, miközben együttmüködnek a gondozókkal. Tájékoztatják egymást a gyerek sorsát érintő kérdésekről. Tehát megállapítható, hogy a gyermek elhelyezésében közremüködő szervezetek közötti koordináció magas színvonalon valósul meg.

A gyermek- és ifjúságvédelmi intézmények két nagy csoportra oszthatók. Az elsőbe tartoznak azok az intézmények, amelyek a gyermek családból való kiemelését próbálják megelőzni és a családot támogatni. Ide tartoznak a szociálpedagógiai nappali csoportok, amelyek leginkább a napközihez hasonlítanak. Az intézmények második nagy csoportját a családhelyettesítőnek nevezett megoldások jelentik. A nevelőotthonok olyan mértékig differenciálódtak, hogy ma már tulajdonképpen nem is érvényes a nevelőotthoni nevelés megnevezés. Több elhelyezési forma áll rendelkezésre a család helyettesítésére. Ilyen például a külső lakócsoport, amely családi házakban müködik. Ezeket a nevelőotthon bérli 5-8 fiatal számára, akikkel a nevelőjük is együtt lakik. A lakóegységek kialakításának alapgondolata a nevelőotthon ,gettó”jellegének feloldása volt. A kisgyermekek számára „gyermekházakat" illetve családi lakócsoportokat hoztak létre, amelyben egy nevelőpár a saját és a nevelt gyermekeivel él együtt. A fiatalok önálló életre való felkészítésére az önellátásra berendezkedett csoportok szolgálnak. Lakást bérelnek, és csak időszakonként keresi fel őket a nevelő. A speciális ellátást igénylő gyerekek számára viszont gyógyító pedagógiai-terápiás nevelőotthont hoztak létre. (Trede, 1993)

Egy más szempontú felosztás az intézményes elhelyezés lehetőségének négy csoportját különbözteti meg. Ezek a lakásotthonok, utógondozó otthonok, a rövid elhelyezés és a zárt elhelyezés. A lakásotthonokban nyolc gyermek és fiatal él együtt egy házban, ahol teljes körü ellátást és felügyeletet biztosítanak számukra. Gyakran a nevelők is a csoportban élnek, így próbálják a családias körülményeket biztosítani.

A lakásotthonok egy-egy gyermekcsoportra jellemző problémára koncentrálva is kialakíthatják szakmai profiljukat. Az utógondozó otthonokban az önálló életre készülő fiatalok élnek, akik már csak alkalmanként kapnak segítséget a nevelőktől. A zárt elhelyezést a büncselekményt elkövető fiatalok számára biztosítják. (Stahlmann, 2000)

Egy következő felosztás az ambuláns keretek között müködő ellátásokat, a nem teljes körü és a teljes körü ellátásokat biztosító intézményeket különíti el az intézményes elhelyezés lehetőségeinek áttekintése során. Ez utóbbihoz a nevelőotthonokat, a nevelőszülői ellátást sorolja. Az ambuláns jellegü ellátások közé tartoznak a nevelési tanácsadók, amelyek a '60-as években terjedtek el Németországban. Kezdetben diagnosztizáltak és tanácsadással foglalkoztak, majd munkájukat viselkedésterápiával, családterápiával egészítették ki. A nem teljes körü ellátások lényege, hogy a gyereket egész napra vagy ennek egy részére kiemelik a családból, 
és pedagógiai, szociálpedagógiai, pszichológiai segítséget kap. Ilyenek például a napos otthonok. A '80-as években egyre több nevelöotthon vezette be ezt a szolgáltatást, ezzel a tevékenységét kiterjesztette azokra a gyerekekre is, akik nem az intézményben élnek. A gyerekek bejárhatnak az otthonokba, ahol terápiás foglalkozásokon vehetnek részt, majd hazamennek. (Csókay, 1995)

A nevelőotthonokra vonatkozóan megállapítható, hogy Németországban nem a klasszikus formában müködnek az otthonok. Új formákat, funkciókat kerestek, és ezért nehéz egységes németországi nevelőotthoni rendszerről beszélni. Sok nevelőotthon különböző ellátási/gondozási formát kínál fel, hogy a gyermekek és a fiatalok különböző problémáira reagálni tudjon. Az intézmények sajátossága, hogy igyekeznek alkalmazkodni a helyi igényekhez, és szolgáltatásokat nemcsak az intézményben élőknek kínálnak. Müködtetnek hagyományos nevelőotthoni csoportokat is, független ifjúsági lakásotthonokat, külső lakócsoportokat, napos csoportokat, ambuláns jellegủ kríziscsoportot, utógondozó részleget. (Stahlmann, 2000)

Hollandiában 1945-ig a „megvédeni és reformálni” jelszavak jellemzőek a gyermekvédelem fejlődésére. Ennek szellemében a gyerekeket kiszakították eredeti környezetükből, hogy a negatív környezeti hatásokat minimalizálják. A gyermekvédelmi szakemberek számára egyértelmúvé vált, hogy a gyerekek visszakerülve a családjukhoz ugyanazt az életet élik, mint korábban. De a „megvédeni és reformálni" jelszavak nem voltak elegendőek a gondozáshoz. Újra kellett gondolni a pedagógiai módszereket. Szakmai viták indultak a veszélyeztetettség, az elhanyagolás fogalmának tisztázására és a probléma megoldására. (Ligthart-NatersKeyser, 1991)

A II. világháború után megkezdődött az intézmények differenciálódása, kialakultak a családoknak nyújtott segítség különböző formái. Ennek hátterében a háború utáni gazdasági nehézségek állhattak, mivel egyre kevesebb adomány érkezett a gyermekvédelem számára. A gyerekek családban történő nevelésének segítése kevesebb költséggel jár, mint a nagy intézmények fenntartása.

A '60-as években újabb változás következett be a gyermekvédelemben. Előtérbe került a prevenció, az intézményes nevelés helyett az ambuláns ellátás, a családias körülmények közötti elhelyezés. Ehhez társult a gyermekjóléti szolgáltatások fejlesztése. A '70-es évekre jellemző, hogy csökkent a bentlakásos intézmények száma és az elhelyezett gyermekek száma is. Az 1970-es években jóval kevesebb szülötől vonták meg a gyermekfelügyeleti jogát, így csökkent az intézményes nevelésben részesülő gyerekek száma is. Míg az 1970-es évek kezdetén 41000 gyereket gondoztak intézményekben, addig ez a szám a '80-as évek közepére 20.000-re csökkent. (Hazai, 1994)

Hollandiában is élénk vita folyt a ' 80 -as években arról, hogy a nevelőszülőknél vagy a bentlakásos otthonokban élnek-e jobb feltételek között a gyerekek. A viták nyomán világossá vált, hogy a kétféle intézménytípus szembeállítása helyett fontosabb azt elemezni, vajon hogyan felelnek meg az alapvetőnek tekintett gondozó- 
nevelő funkciójuknak. Egyetértés alakult ki abban, hogy a nevelőszülöi családok hatékonyabban tudják ellátni a szocializációs feladatokat, mint a bentlakásos otthonok. Kiderült az is, hogy új típusú problémák vannak kialakulóban, amelyeknek a megoldásához nem elegendő a nevelöcsaládok ösztönös tevékenysége. Egyre gyakrabban kell terápiás szakembereket is segítségül hívni a gyermekvédelmi problémák kezeléséhez. (Hazai, 1994)

A nevelőszülők kiválasztását és felkészítését Nevelőcsaládi Központokban végzik a szociális szakemberek. A központok alapítványi formában müködnek. A nevelőszülőknek különböző feltételeknek kell megfelelniük, és alkalmassági vizsgálaton vesznek részt. A nevelőszülői szolgáltatások különböző modulokra bonthatók. Az egyes modulok a nevelőszülőknél eltöltött időtartam mentén szerveződnek. A szokásos nevelőcsaládban a tartós gondozásra szoruló gyerekeket nevelik. A terápiás nevelőcsaládban a szülőket szakemberek segítik a problémás gyerekek nevelésében. A szállásadó család olyan fiataloknak ad szállást és ellátást, akik már önállóak. A hétvégi család egy vagy több hétvégére fogadja be a gyereket. A krízis nevelőszülő a krízishelyzetben levő gyereket látja el 1-3 hónapon át. Az üdültető család egyszeri alkalommal nyári üdültetésre fogad gyerekeket. A terápiás családok olyan 10-16 éves fiatalokat látnak el, akik már több nevelöszülőnél is voltak, és nem volt eredményes a nevelésük. Szakemberek intenzíven támogatják a családot. A nevelőszülők között vannak olyanok, akik hosszú időre biztosítanak ellátást a gyerekeknek. Itt általában a vér szerinti szülő nem tudja rendezni az életkörülményeit, így a gyerek tartós elhelyezésére van szükség. (Strijker, Knorth 2007)

A bentlakásos intézményeknek is több típusa van. Az intézmények fenntartásának magas költségei miatt az elmúlt években az ambuláns, otthoni ellátás került előtérbe. Az intézményes gondozást több kritika érte a '80-as években. A kormányzat az intézményekre fordítható költségeket jelentősen csökkentette, mivel túl drágának és alkalmatlannak találta a fiatalok megsegítésében. A '80-as években több intézményt bezártak, az intézményes nevelés háttérbe szorult. (Ligthart-NatersKeyser, 1991) Tehát az intézményrendszer müködését, átalakításának prioritását jelentősen befolyásolták az anyagi lehetőségek.

A kormányzat kevésbé preferálja az intézményes elhelyezést, mint a nevelőszülőit. Ennek ellenére nő az intézménybe belépők száma, noha a kormányzat csökkenteni igyekszik az otthonokban élők számát. Jellemző, hogy az intézményekben várólisták vannak a kapacitáshiány miatt. A holland helyzet a fiatalok által elkövetett erőszakos cselekedetek növekvő számával magyarázható. Ezeknek a fiataloknak az elhelyezése más körülmények között nem biztosítható. (Knorth, 2002)

Az intézményekben történő elhelyezésre a gyerek állapotának függvényében több lehetőség kínálkozik Hollandiában is. A fogadócentrumok azonnali elhelyezést biztosítanak átmeneti időre, amíg nem tisztázott a gyerek helyzete. A megfigyelőközpontba akkor kerül a gyerek, ha hosszabb megfigyelésre van szükség 
állapotának a feltérképezéséhez. Ebben az esetben az intézmények hosszabb időre biztosítanak elhelyezést. A speciális kezelőintézmények a beilleszkedési zavarokkal küzdő gyerekek elhelyezésére szolgálnak. Az intézményes nevelés előnye, hogy a nagy intézmények száma csökkent, helyettük kisebb méretű családias lakásotthonok jöttek létre. Ezekben kisebb létszámú gyerekcsoportok élnek, jobb tárgyi feltételek között müködnek, és az intézményben dolgozók képzettebbek. (Ligthart, Naters-Keyser, 1991)

A II. világháború Franciaországban is új helyzetet teremtett a gyermekvédelem számára. A háború után létrejöttek a közigazgatási gyermekvédelem intézményei is. 1955-ben megszületett az a törvény, amely azoknak a családoknak a védelméről gondoskodott, akiknek a fizikai, gazdasági, pszichés egyensúlya megbomlott, de a veszélyeztetett gyerekek védelmét továbbra is az intézményekben látták orvosolhatónak.

A '70-es évek végén a '60-as évek mozgalmai, a gazdasági recesszió miatt a gyermekvédelmet is egyre nehezebb volt finanszírozni. Az intézmények jelentős pénzeszközöket emésztettek fel, de nem tudtak elég gyorsan alkalmazkodni a megváltozott igényekhez. A rendszer nehézkessé válását annak átalakításával próbálták megakadályozni.

Ezt a törekvést fogalmazza meg az 1983-as és az 1986-os törvény, amely a gyermekvédelmi intézkedéseket a megyék hatáskörébe utalta, bízva a helyi szabályozás nagyobb eredményességében. (Hazai, 1994)

Franciaországban a gyermekvédelmi feladatokat az anya-, csecsemö- és gyermekvédelmi szolgálat, a szociális segítő szolgálat és a területi szociális hálózat látja el. A gyermekvédelmi intézkedések meghozatala a megyegyülés elnökének a feladata. Ha a család nem tud a gyermekvédelmi intézményekkel együttmüködni, akkor gyermekbíróságra kerül az ügy, ahol kötelezö érvényü döntéseket hoznak. Amennyiben a gyermek veszélyeztetettségét nem sikerül megszüntetni, hatósági intézkedésre kerül sor, a gyereket kiemelik a családjából. A gyermek ellátására az egyik lehetőséget a nevelőszülői elhelyezés biztosítja. A nevelőszülők a megye szociális segítőszolgálatához tartoznak, itt képzésben vesznek részt, és a feladatra való alkalmasságukat is megvizsgálják. Munkaviszony keretében, szerződéssel végzik ezt a tevékenységet. A nevelőszülők szakmai segítését a kihelyező szerv végzi.

Az elhelyezés másik lehetősége az intézményes nevelés. Az intézményeket is a megyék tartják fenn a szociális szolgálaton keresztül. A Szociális Segítőszolgálat helyezi el a gyermeket a megfelelő intézményben és ellenőrzi az intézmény munkáját. A francia statisztikai adatok szerint 2004-ben 13.426.557 0-17 éves korú gyermek élt Franciaországban. Közülük 137.085 fö szorult gyermekvédelmi gondoskodásra. A gyerekek 7\%-a rokonoknál kapott elhelyezést, 46\%-uk nevelőszülőknél, 40\%-uk pedig gyermekotthonokban élt.(INSEE, 2004.) Az adatok szerint a nevelöszülöi elhelyezési forma a gyakoribb. 
Az intézményekben elhelyezett gyerekek állapota befolyásolja az elhelyezés lehetőségeit. A tanulási nehézséggel küzdő, mozgásfogyatékos, mentális betegségben szenvedő gyerekeket a helyi speciális, bentlakásos iskolában vagy nem bentlakásos iskolában látják el. A szociális hátrányok miatt bekerülő gyerekek ifjúságvédelmi gyerekotthonba kerülnek. Ezeket az intézményeket a Szociális Segítő Szolgálat müködteti. A bünelkövető fiatalokat az Igazságügyi Minisztériumhoz tartozó javító intézetekben helyezik el. Az elmúlt években vezették be, hogy a bünelkövető fiatalok a családjukban élnek tovább, és az AEMO (Külső Környezeti Nevelő Szervezet) felügyeli őket. A pszichiátriai betegségben szenvedő gyerekeket egészségügyi intézményekben helyezik el, aminek a felügyeletét az Egészségügyi Minisztérium gyakorolja. A fogyatékkal élö gyerekek és fiatalok speciális intézményekbe kerülnek, ahol oktatásban és rehabilitációban részesülnek. Az intézményekben alapelv, hogy a családdal tartani kell a kapcsolatot. A legfontosabb cél a gyermek családba való visszahelyezése. (Vidaud, 1991)

Jellemzö, hogy a nagy otthonokat Franciaországban is megszüntették, legfeljebb 60-80 fős otthonok müködnek. A kastélyokat és az egyéb nagy intézményeket felváltották a kisebb, családiasabb elhelyezést biztosító otthonok. Minden otthon sajátos arculattal rendelkezik. Az elmúlt években terjedtek el a 10-15 föt befogadó intézmények, és a lakásotthonok, ahol 5-6 fiatal kap helyet.

A II. világháború Angliában is sürgetővé tette a gyermekvédelmi intézkedéseket. A háború után visszaesett a gyermekotthonok számának növekedése. A Curtis Bizottság 1946-ban végzett vizsgálatot Angliában és Walesben. A kutatás felhívta figyelmet a mostoha intézményi körülményekre, és helyette a nevelőszülői elhelyezést javasolta.

Az 1948-ban bevezetett törvény a Gyermekekről (Children Act) a gyermek érdekeinek képviseletére helyezte a hangsúlyt, és a gyerek családban történő nevelését tartotta elsődlegesnek. Ennek megvalósításához szükséges volt a család rehabilitációja. A szülő és az otthoni környezet hangsúlyosabb lett, a nevelőszülői elhelyezést támogatták az intézményes neveléssel szemben. Ebben az időszakban Angliában a helyhatóságoké volt a vezető szerep a gyermekvédelemben, létrehozták a gyermekügyi osztályokat, amelyek a családokkal is tartották a kapcsolatot.

Az 50-es években indul meg az intézmények leépítésének folyamata, aminek lényege, hogy a gyerekek kerüljenek ki az intézményekből, mert elönyösebb a családi körülmények közötti nevelés. Az állam így csökkenteni akarta a kiadásait a gyermekvédelem területén. Az '50-es évek óta a nagy intézmények eltüntek, kisebb családiasabb lakóegységek jöttek létre. A lakásotthoni forma egyre elterjedtebb Angliában, az utóbbi évtizedekben. A 8-10 főből álló gyermekcsoport családias körülmények között, családi házban lakik a gondozóval együtt. Kezdetben sok nevelő is bent lakott ezekben a lakásotthonokban, mára inkább csak az éjszakát töltik benn. A gyerekek és fiatalok ezekből az intézményekből iskolába járnak és 
tartják a kapcsolatot a szülőkkel, kivéve akkor, ha a kapcsolattartás nem szolgálja az érdeküket. (Kahan, 1991)

2007-es adatok szerint Angliában 60.000 gyermek van gondozásban. Nemüket tekintve $56 \%, 33400$ fö fiú, és 44\%, 26.600 fö lány. Többségük (71\%, 42300 fö) nevelőszülőknél került elhelyezésre, 12\%-uk, 7110 fő gyermekotthonokban, 9\%uk, 5100 fö visszakerült a szüleihez és $4 \%$-ukat, 2500 föt örökbefogadtak. (British Association for Adoption \& Fostering, 2007) Az adatok alapján megállapítható, hogy Angliában a nevelőszülői elhelyezés a preferált, a gyerekek túlnyomó többsége itt kerül elhelyezésre.

5. táblázat. Családjukból kiemelt gyermekek életkori megoszlása Angliában 2007

\begin{tabular}{|l|c|c|}
\hline Életkor & Fö & \% \\
\hline 1 évesnél fiatalabb & 3000 & 5 \\
\hline 1-4 év között & 8800 & 15 \\
\hline 5-9 év között & 10.900 & 18 \\
\hline 10-15 év között & 25.500 & 42 \\
\hline 16- & 11.800 & 20 \\
\hline
\end{tabular}

Forrás: Children in public care. www.baaf.org.uk/info/stats/england.shtml 2008. 09.13

A 5. táblázat adatai alapján jól látszik, hogy a családjából kiemelt gyerekek között a legtöbben a 10-15 éves korosztályba tartoznak, a gyerekek mintegy $42 \%$ - a. Öket követi a 16 évesnél idősebb korosztály 20\%-kal. A kiemelt gyerekek között a legkisebb arányban az 1 évesnél fiatalabb, és az 1-4 éves korosztály van jelen 5 és $15 \%$-os arányban. Az adatok alapján megállapítható, hogy Angliában a többi európai országhoz hasonlóan a serdülőkorú gyerekek intézménybe való beáramlása a legjelentősebb. Ennek oka egyrészt a serdülökorban bekövetkező pszichés változásokban keresendő, másrészt oka lehet az is, hogy a különböző segítő intézmények sokszor évekig próbálkoznak a családok segítésével annak érdekében, hogy a gyerek a családban nevelkedhessen, ez azonban nem mindig jár eredménnyel.

Az intézményekben élő gyerekek 2/3-a emocionális és viselkedési problémákkal küszködik. Ez kizárja, hogy máshol helyezzék el őket. Ezek a gyerekek tipikusan 13-14 évesek, és nevelöszülöi elhelyezésük sikertelen volt. A fiatalok kb. harmada szexuális bántalmazást szenvedett el az intézményes elhelyezést megelözően. (Warner, 1997)

A fiatalok sokszor szívesebben választják az intézményes nevelést a nevelöszülöi elhelyezéssel szemben. Különösen igaz ez azokra, akik valamilyen bántalmazást szenvedtek el. Az intézményes elhelyezést elsősorban azokban az esetekben 
alkalmazzák, amikor a fiatal komplex értelmi, érzelmi, viselkedésbeli nehézségekkel küzd, és nem képes a szabályok betartására. (Sinclair, Gibbs, 1998)

A nevelőszülői elhelyezés jellege és időtartama szerint a következőképpen csoportosítható. Rövid időtartamú nevelőszülői elhelyezés legfeljebb 3 hónap: örökbefogadás előtti kihelyezés esetén, krízisintervenció esetén, döntést megelöző időszakban az intézményi elhelyezést megelőző átmeneti megoldásként alkalmazzák. A középtávú elhelyezés a maximum 3 évig tartó nevelőszülői elhelyezés. A cél itt is a gyerek vér szerinti családjába való visszahelyezése. Angliában is létezik a magyarországihoz hasonló „hagyományos” nevelőszülöi elhelyezés, ahol fizetést nem kap a nevelöszülő, csak a gyermek ellátását fedező juttatásokat. Speciális nevelőszülők azok, akik hasonlóan a magyar rendszerhez fizetést kapnak, a helyi önkormányzat fizeti őket, mint munkavállalókat. Ide kerülhetnek a bünelkövető, sérült, magatartási zavarokkal küzdő gyermekek.

A nevelőszülöi elhelyezés harmadik típusa a váratlan problémák áthidalását célzó nevelőszülői elhelyezés, amikor a már valahova elhelyezett gyermek helyzete megromlik. (Herczog, 1994)

A 70-es évek közepétől a nevelöszülői elhelyezés egyik lehetséges formája a hosszú távú nevelőszülői elhelyezés. 1988 óta a nevelöszülő megkapja a gyámságot, dönthet a gyerek sorsáról, de nem változtathatja meg a gyermek nevét, állampolgárságát. A vér szerinti szülőnek láthatási joga van, az örökbefogadásnál meg kell kérdezni a véleményét. A gyerek fölötti gyámság a 18. életév betöltésével szünik meg.

A nevelőszülők egyre inkább a gyermekek jövőbeli kilátásaiért felelős szakképzett csoportokká váltak. Az a felismerés, hogy a nevelöszülő a gyermek leendő munkaerőpiaci pozícióját meghatározó tényező, újabb igazolása annak, hogy a nevelőszülői szerep változóban van. (Tapsfield-Collier, 2008)

\subsection{A kelet-közép európai országok gyermekvédelme}

A kelet-közép-európai országokban jelentôsen befolyásolta a gyermekvédelmet a II. világháború után kialakuló szocializmus, ami együtt járt az állam központosító törekvéseivel. A paternalista állam preferálta a közösségi nevelést, ennek megvalósítása érdekében hozta létre a nagy létszámú gyermekotthonokat. A nagy otthonok alacsony hatékonysága egyre nyilvánvalóbbá vált a szakemberek számára. A rendszerváltás utáni években megfogalmazódott a változások iránti igény. Így ezen országok elsősorban a nyugat-európai tapasztalatokat felhasználva átalakították az intézményrendszerüket. Ezt a fejlödési modellt mutatjuk be a következőkben.

Lengyelországban a II. világháború után centralizált gyermekvédelmi rendszer müködött, mert a szocialista állam központosító törekvései ezen a területen is ér- 
vényesültek. A modell középpontjában a gyerekek közösségi nevelése állt. A vér szerinti családjuktól távol kerültek, elsősorban nagy létszámú nevelőotthonokba. Ennek következtében az elhelyezés egyúttal a családi kapcsolatok szétszakadását is jelentette. A családok segítésére nem álltak rendelkezésre szociális szolgáltatások.

A rendszerváltás a szociálpolitika változásával is együtt járt. Ezekben az években új fejezet kezdődött a családok és gyerekek gondozásában. A gyermek- és családgondozás alapját az 1990-ben bevezetett szociális törvény teremtette meg, ami a gyerekről való gondoskodást elsődlegesen a család feladatának tekinti. Abban az esetben, ha ez nem lehetséges nevelőszülőnél kell elhelyezni a gyereket. Intézménybe csak akkor kerülhet, ha már minden más lehetőség kimerült. A nevelöszülöi és az intézményes elhelyezés a kerületi családsegítő megbízásából történik, aminek a müködését a szociális törvény szabályozza.

A törvényben alapelvként fogalmazták meg, hogy segíteni kell a gyerek és a vér szerinti család közötti kapcsolatot, annak érdekében, hogy visszakerülhessen a gyerek a családba.

Az új szabályok megvalósítása nem könnyü feladat. Lengyelországban ugyanis túl sok gyerek él nagy házakban 80-100 férőhelyes intézményekben. A változások a kisebb lakásegységek kialakítását sürgetik. A gyermekotthonoknak Lengyelországban három nagy csoportja van. Az egyikben a kicsi gyerekek elhelyezése valósul meg legfeljebb 3 éves korig. Ezek az otthonok az Egészségügyi és Szociális Minisztériumhoz tartoznak. Az otthonok másik csoportjába 3-tól 18 éves korig kerülnek a gyerekek, a nevelésükért, oktatásukért az Oktatási Minisztérium a felelős. A harmadik csoportot a bünelkövető fiatalok otthonai jelentik, amelyek az Igazságügyi Minisztérium fennhatósága alá tartoznak. (Kruszko, 1991)

Egy másik felosztás a következő intézményeket különbözteti meg: a szocializációs centrumokhoz tartoznak a gyermekotthonok, a családi otthonokhoz sorolják a gyermekfalvakat, a gyermeket családdal együtt elhelyező otthonokat, az intervenciós centrumokhoz tartoznak a krízishelyzetet ellátó intézmények. A következő típust a multifunkcionális centrumok alkotják. Ezek az intézmények nappali ellátást, 24 órás terápiás ellátást, szocializációs és intervenciós szolgáltatásokat nyújtanak a gyerekek és családjuk számára. Lengyelországban ún. gyógyító intézményekben látják el a kórházi ápolást nem igénylö, de hosszú távú gondozást igénylő gyerekeket. (Lengyel Statisztikai Hivatal, 2006).

A gyermekotthoni elhelyezést tanácsolhatja a helyi hatóság, rendőrség, szociális szervezetek vagy akár a szomszédok is. Amennyiben krízishelyzet áll elő, a gyerekek az intézmény sürgősségi részlegére kerülnek, ahol néhány héttől 3 hónapig tartózkodhatnak. Ez alatt az idő alatt tesztekkel vizsgálják a gyerekeket, megállapítják, hogy visszahelyezhetőek-e a családjukba. Ha a család nem alkalmas a visszafogadásra, valamelyik gyermekotthonban helyezik el őket. (Kruszko, 1991)

A gyermekotthonok müködésére jellemző, hogy lényeges különbségek van- 
nak az otthonok között pedagógiai és szervezési szempontból. A csoportok öszszetételére jellemző, hogy azonos nemú, de különböző életkorú gyerekekből állnak. A gyermekotthonok Lengyelország területén szórtan helyezkednek el. A statisztikai adatok szerint 458 gyermekotthon van 86 sürgősségi részleggel. Az elmúlt években a férőhelyek száma csökkent, ezzel egyidejüleg a nevelőszülők száma, valamint a gyerekek saját családba való visszahelyezése növekedett.

Az otthonok méretére jellemző, hogy 128 otthonban a gyerekek száma nem haladja meg az 50 föt, 111 otthonban 50 és 100 fö közötti a gyerekek száma, és 18 olyan otthon van, ahol meghaladja a 100 föt az elhelyezettek száma. (Kruszko, 1991). Lengyel szakemberek szerint az az optimális cél, hogy a csoportok létszáma ne haladja meg a 16 föt.

A túl nagy csoportlétszámok nem teszik hatékonnyá a munkát. A lengyel szociális és oktatáspolitika fó célja, hogy a gyerekek minél rövidebb időt töltsenek intézményekben, amint lehet, családias körülmények között nevelkedjenek. Ez a politika elvárja a gyermekotthonoktól, hogy kapcsolatot tartsanak a gondozott gyerekek szüleivel. A peremhelyzetü szülőkre azonban gyakran jellemző, hogy a gyerekkel való kapcsolattartásuk véletlenszerü, és gyakran több kárt okoz a gyereknek, mint örömet. A gyermekotthonok együttmüködnek baráti családokkal, amelyek nincsenek rokoni kapcsolatban a gyerekekkel. Ök általában önkéntesek, akik hétvégére otthonukba viszik a gyereket. Gyakori, hogy ezek gyerek nélküli családok, és az örökbefogadás valamiféle pszichológiai előkészítése ez a folyamat.

Jellemző, hogy a gyerekek hosszú ideig tartózkodnak az otthonokban. A kisebb gyerekeknek általában nagyobb esélye van az örökbefogadásra, a 2 évnél fiatalabbak rövidebb ideig vannak az intézményekben. 62.000 gyerek van intézményes elhelyezésben, szemben azzal az 50.000 fővel, akit nevelőszülőknél helyeztek el. (Stelmaszvk, 2002)

Lengyelországban, 2005-ben 105.432 gyerek élt a családján kívül. Közülük 55.765 fö gyermekotthonokban került elhelyezésre, 49.667 fő pedig nevelöszülöknél.(TRANSMONEE, 2007. UNICEF, Innocenti Research Center). Az adatok az intézményes elhelyezés túlsúlyát mutatják.

Az intézményi elhelyezés alternatívája Lengyelországban is a nevelöszülői elhelyezés. Ez az elhelyezés többféle formában valósulhat meg. A nevelőszülő lehet a gyerekkel rokoni kapcsolatban álló, rokoni kapcsolatban nem álló, valamint rokoni kapcsolatban nem álló professzionális nevelőszülő. A gyerekkel rokoni kapcsolatban nem álló professzionális nevelőszülők további típusa a speciális nevelőszülő, a krízis nevelőszülő. A krízis nevelőszülő legfeljebb 12 hónapig látja el a gyereket. 2000 óta szervezik ezt az ellátási formát, azoknak a gyerekeknek, akiknek rövidebb idejü gondozásra van szüksége. A speciális nevelőszülő az egészségi problémákkal küzdő gyerekeket látja el.

A rendszerváltás utáni években jelentősen változtak a gyerekek elhelyezési lehetőségei. Mivel azonban nehéz nevelőszülőt találni, ezért a gyermekvédelmi 
rendszer fontos része maradt Lengyelországban a gyermekotthoni elhelyezés. A lengyel kormányzat további célja, hogy fejlessze a családok segítését, támogassa a családokat a gyermeknevelésben annak érdekében, hogy minél kevesebb gyerek kerüljön otthonokba. (Stelmaszvk, 2002)

$\mathrm{Az}$ egykori Csehszlovákia gyermekvédelmében is fordulópontot jelentett a II. világháború utáni időszak. A háborús pusztítás következtében jelentősen megnőtt az árvák, a gondoskodásra szorulók száma.

Az ifjúsági jóléti szervezeteket feloszlatták, és az állam átvette az elhagyott gyerekek ellátását. Az 1953-as oktatási törvény alapján a gyermekotthonok az oktatási rendszer részévé váltak. A pedagógiai követelmények megjelenése egy fontos fordulópont a gyermekotthonok életében. A legfontosabb fejlesztések közé tartozott a tárgyi környezet és az oktatás körülményeinek a javítása.

Az otthonoknak két nagy típusa van: az egyikbe tartoznak azok a családias jellegü otthonok, amelyek az előreláthatóan hosszú időre elhelyezést igénylőknek nyújtanak szolgáltatást. A másik csoportba azokat a gyermekotthonokat sorolják, amelyek a rövid idejü elhelyezést igénylők szükségleteit elégítik ki. (Hrdlickova, 1991)

Mára megnőtt a szociális szolgáltatók jelentősége és száma. Ezek a szolgáltatások szociálpedagógiai segítséget nyújtanak a különböző kapcsolati zavarok, problémák kezelésében. Ha a segítség nem hozza meg a várt eredményt, akkor kerül sor a gyermek családból való kiemelésére. A gyerek elhelyezése közeli rokonnál, nevelőszülőnél, örökbefogadó szülőnél, valamint intézményben történhet. A gyermekotthoni elhelyezést a bíróság ajánlja a szülőknek. Az elhelyezés időtartama függ a változásokhoz szükséges időtől, a családi környezettől, a gyerek fejlettségétől. A családi típusú gyermekotthonban hosszú ideig lehet tartózkodni a gyerek 3 éves korától 18 éves koráig, amíg szakmát tanul. A bentlakásos iskola jellegü gyermekotthonban a fiatal rövid ideig tartózkodik. Lehetőség van a gyerekek diagnosztikai centrumban való elhelyezésére is, abban az esetben, ha a szülök nem tudják maguk megoldani a problémát. Itt két hónapig tartózkodhatnak a gyerekek, és pedagógiai, pszichológiai vizsgálatokon vesznek részt, bekapcsolódnak az oktatásba. Ezzel egyidejüleg végzik a család szociális gondozását. A gyerekek a diagnosztikai centrumok megfelelő osztályaiba kerülnek, ahol pedagógiai megsegítésben részesülnek. A bentlakásos iskolatípusú otthonban 12-15 fiú vagy lány kerül elhelyezésre, akik hasonló életkorúak. A családi típusú otthonokban 8-10 fő számára biztosítanak ellátást. Ezek kis léptékü intézmények, amelyekben két nevelő vagy egy házaspár biztosítja a pedagógiai gondozást.

A családi típusú otthonhoz hasonlóan müködnek a gyermekfalvak. Egy-egy faluban 16 család él. Egy házaspár a gyerekeivel valamint a gondozott gyerekekkel. A gyermekfaluban van óvoda, iskola, ami a szomszédságban élő gyerekeknek is rendelkezésére áll. Az otthonok szerkezeti átalakítása szükséges a gyerekcsoportok létszámát 6-10 före kell csökkenteni, a nagy intézményeket pedig kisebb családias egységekké átalakítani. (Hrdlickova, 1991) 
Csehország és Szlovákia 1993-ban kettévált, két önálló ország jött létre. A változások a gyermekvédelmet is érintették, amit a következőkben mutatunk be.

Szlovákiában a gyermekvédelem átalakulását jelzi, hogy pszichológiai tanácsadó hálózatok müködnek, ahol egyéneknek, pároknak és családoknak adnak tanácsot. Itt segítik az elhagyott gyerekeket, hogy be tudjanak illeszkedni az új családjukba, segítik a fiatalokat életvezetési tanácsokkal.

2005-ben 12227 gyerek élt a családján kívül. Közülük 8977 intézményes körülmények között, 3250 fő nevelőszülőknél kapott elhelyezést. Az adatok az intézményes elhelyezés túlsúlyára utalnak. (TRANSMONEE, 2007. UNICEF, Innocenti Research Center)

2005-ben a Szlovák Köztársaságban 91 gyermekotthon múködött. A 91 otthonból 75 állami fenntartású, 5 egyházi, 8 egyéb fenntartású gyermekotthon. Az intézmények törekednek a családias körülmények biztosítására. A gondozást a születéstől a nagykorúságig biztosítják, de maximum 25 éves korig. A gondozás része a szállás biztosítása, az élelmezés, egészségügyi ellátás, a szabadidő, a rekreáció megvalósítása. A gyermekotthonban egyéni gondozási terv készül, amely tartalmazza a gyermek oktatására vonatkozó feladatokat, valamint a szociális munkás tervét a gyerekre és családjára vonatkozóan (Placintar, Olexa, 2006)

Speciális formája a gondozásnak a családi helyettesítő gondozás. A helyettesítő gondozás bírósági döntés eredményeként jön létre, és a gyermek nagykorúvá válásával veszti érvényét. A helyettesítő gondozást csak házaspároknak engedélyezik, írásos szerződés alapján. (Placintar, Olexa, 2006)

2005-től kezdődően a gyermekvédelemben is a prevencióra helyezik a hangsúlyt, ami azt jelenti, hogy meg kell előzni a kritikus helyzet kialakulását a családban. Fontos alapelv lett, hogy a gyerek mindenek felett álló érdekét kell biztosítani a gyermekek jogairól szóló egyezmény szerint. A gyermekvédelmi szemlélet megújítását tükrözi az is, hogy fejlesztik a családból kiemelt gyerekek elhelyezésének lehetőségeit

Csehországban a gyermekvédelem átalakítása után 3 típusba sorolhatók az intézmények. Az elsőbe a csecsemő- és gyermekotthonok tartoznak, amelyek legfeljebb a gyerek 3 éves koráig biztosítanak ellátást, és ezek az Egészségügyi Minisztérium fennhatósága alatt müködnek. 2004-ben 37 ilyen típusú intézmény müködött. A második típusba azok a gyermekotthonok tartoznak, amelyek 3-tól 18 éves korig látják el az elhagyott, problémás gyerekeket, ezek az Oktatási, Ifjúsági és Sport Minisztérium igazgatása alatt müködnek. 2004-ben 219 ilyen intézmény müködött. A harmadik típusú intézményben a fogyatékkal élő gyerekeket látják el. Ezeket az intézményeket a Szociális és Munkaügyi Minisztérium igazgatja. 2004-ben 170 ilyen típusú intézmény müködött Csehországban. Az intézményekben a családias körülmények biztosítására törekednek. Ez megnyilvánul a gyerek és csoportlétszám csökkentésében, ami segíti az eredményorientált fejlesztést, valamint abban is megnyilvánul, hogy a csoport élete jobban hasonlít a családi körülményekhez. 
6. táblázat. Gyermekvédelmi gondoskodásban elhelyezett gyerekek száma Csehországban

\begin{tabular}{|l|c|c|c|c|c|c|}
\cline { 2 - 7 } \multicolumn{1}{l|}{} & $\mathbf{2 0 0 0}$ & $\mathbf{2 0 0 1}$ & $\mathbf{2 0 0 2}$ & $\mathbf{2 0 0 3}$ & $\mathbf{2 0 0 4}$ & $\mathbf{2 0 0 4 / 2 0 0 0}$ \\
\hline Csecsemőotthonokban & 1723 & 1655 & 1630 & 1624 & 1570 & 91,1 \\
\hline $\begin{array}{l}\text { Gyermekotthonok } \\
\text { és bentlakásos } \\
\text { iskolákban }\end{array}$ & 7333 & 7222 & 7270 & 7205 & 7590 & 103,5 \\
\hline $\begin{array}{l}\text { Ebból } \\
\text { gyermekotthonban }\end{array}$ & 4624 & 4634 & 4594 & 4612 & 4867 & 105,3 \\
\hline $\begin{array}{l}\text { Fogyatékkal élő } \\
\text { gyerekek otthonában }\end{array}$ & 12783 & 12750 & 12806 & 12851 & 12864 & 100,6 \\
\hline Nevelőszülőknél élők & 6000 & 6411 & 6598 & 6637 & 6565 & 109,4 \\
\hline $\begin{array}{l}\text { SOS gyermekfaluban } \\
\text { élők }\end{array}$ & 1073 & 965 & 992 & 1076 & 1270 & 118,4 \\
\hline $\begin{array}{l}\text { Összes gondozásban } \\
\text { élő gyermek }\end{array}$ & 28912 & 29003 & 29296 & 29393 & 29859 & 103,3 \\
\hline 0-17 évesek száma & 2066845 & 2021997 & 1985487 & 1947940 & 1916356 & 91,1 \\
\hline
\end{tabular}

Forrás: Czech Statistical Office (2006): System in support of children without parental care in the Czeh Republic, Prague: Czeh Statistical Office. Country Analytical Report prepared for the MONEE Project, UNICEF IRC 2. o.

A 6. táblázat adatai alapján megállapítható, hogy 2000 és 2004 között a 0-17 éves korosztályba tartozók száma 8,9 \%-kal csökkent. De ugyanebben az időszakban a gondozásba vett gyerekek száma 3,3 százalékkal növekedett. Ez a tendencia arra utal, hogy romlott a családok helyzete. A csecsemőotthonokban elhelyezett gyerekek aránya 2004-ben 2000-hez képest 9\%-kal csökkent. A többi intézménytípusban elhelyezett gyerekek száma növekedett. Így a gyermekotthonokban élök aránya 5,3\%-kal, a fogyatékkal élő gyerekeket ellátó intézményben elhelyezettek arány 0,6\%-kal, az SOS gyermekfalvakban elhelyezett gyerekek aránya 18,4 \%-kal nőtt 2004-ben 2000-hez képest. A nevelöszülöi elhelyezés aránya 9,4 \%-kal növekedett 2004-ben 2000-hez képest. Az adatok alapján megállapítható, hogy lassú elmozdulás figyelhető meg a gyerekek nevelőszülőknél való elhelyezésének irányába. A nevelőszülői elhelyezésnek több formája létezik Csehországban is. Megkülönböztetnek egyéni nevelőszülőket, gyámszülőket és csoportban dolgozó nevelőszülőket. A ,gyámszülöt” akkor nevezi ki a bíróság, ha a szülő meghalt vagy megfosztották szülői jogától. A ,gyámszülő” feladata a gyerek nevelése és segítségnyújtás a vér szerinti családba való visszakerüléshez. Hasonlóan müködnek, mint a nevelőszülök. A gyermeket érintő fontosabb kérdésekben a ,gyámszülő” csak a bíróság jóváhagyásával dönthet.

A nevelöszülöi elhelyezés keretében elsősorban azokat a gyerekeket látják el, akiket egészségi vagy szociális okok miatt nem tudnak örökbe fogadni. A nevelö- 
szülök díjazás ellenében látják el a feladatukat. A gyermekek védelmét különböző más törvények is szabályozzák Csehországban. Tradicionálisan az alkotmány mondja ki a gyermekek védelmét, valamint a családjogi törvény tartalmaz ide vonatkozó szabályokat. A családjogi törvényt 1998-ban kiegészítették a gyerekek védelmére és jólétére vonatkozó szabályokkal. A törvény kimondja, hogy a gyerekek jóléte és védelme elsődleges, mindenek feletti. Mindezek mellett a törvény lefekteti, hogy az állam kötelezettséget vállal.

A cseh kormányzat a Gyermekek Jogairól Szóló Egyezmény értelmében törekszik a családok megerősítésére, a gyermeket nevelö családok hatékony segítésére, biztosítja a gyerekek védelmét a fizikai, mentális bántalmazással szemben, valamint segíti a bántalmazást elszenvedett gyerekek rehabilitációját. Segíti a családokat annak érdekében, hogy minél kevesebb gyerek kerüljön az intézményes ellátásba.

A közép-kelet-európai országok közül Romániában volt a legrosszabb a gyermekvédelem helyzete a diktatúra idején. Az intézményes ellátás a minimális feltételeknek sem felelt meg. Erre 1989-ben figyelt fel a világ, dokumentumfilmek sora járta be Európát és mutatta be az intézményben nevelkedő gyerekek mostoha életkörülményeit. Romániára 1990-től nemzetközi nyomás nehezedett, hogy javítson a gyerekek sanyarú helyzetén. A romániai gyermekvédelmi intézmények sajátos fejlődési utat jártak be a többi közép-kelet-európai országhoz képest. Ez azzal magyarázható, hogy itt még később kezdték meg az intézmények átalakítását, és külső nyomásra is szüksége volt az országnak ahhoz, hogy változtasson a helyzeten.

A romániai intézmények 1989 előtti müködésének sajátosságai a következőkben foglalhatók össze. Az intézmények nagy létszámúak, általában 100 és 400 férőhelyesek voltak. Az épületek alkalmatlanok a feladat ellátására (régi, hideg kastélyok vastag falakkal). Gyakran kisebb, eldugott településeken helyezték el a gyerekeket. Sok helyen nem volt bevezetve a gáz és/vagy a víz -az ország egészére is jellemzően-tehát nehéz volt megfelelően megoldatni a tisztálkodást, mosást, főzést. Kevés volt a tüzelőanyag, télen a nagy hidegben nem volt elégséges a fütés. A személyzet szakképzetlen és kevés volt. Az intézetek zártak voltak, kevés volt a látogató, nem keresték a kapcsolatot a szülökkel, a gyerekek számára majdnem lehetetlen volt átkerülni egyik intézetből a másikba. Az intézmények fenntartására szánt pénzt minimalizálták. Ebből a helyzetből kellett 1990-ben változásokat foganatosítani a nemzetközi nyomás hatására is. A nyugat-európai országokból számtalan segélyszervezet küldött adományokat az intézmények számára. Nemcsak tárgyi adományok, de önkéntes segítők is érkeztek, akik a gondozó személyzet képzésében segítettek. 1992-ben új országos Gyermekvédelmi Bizottság alakult, amely egyesíteni kívánja a gyerekekkel kapcsolatos különböző intézkedéseket. Erre azért volt szükség, mert a megfigyelők a gyermekvédelemben felmerülő problémák egyik okát az e területen meghozott rendelkezések összehangolatlanságára vezették vissza.(Roth, 1995)

A reformok hatására megkezdődött a gyermekvédelmi intézmények szerkezeti átalakítása. Csökkentették az intézmények méretét, növelték a számukat, fejlesz- 
tették a szolgáltatásokat, decentralizálták a rendszert a gyermekek szükségleteinek figyelembe-vételével. A non-profit szervezetek lehetőséget kaptak a gyermekvédelembe való bekapcsolódásra, a szolgáltatások minőségét javították.

A 2004-es gyermekvédelemről szóló törvény segítette a változások megvalósítását. Ebben a törvényalkotók összefoglalták a gyerekek jogait, tisztázták a szülök feladatait a gyerekek fejlődésének biztosítása érdekében, valamint a helyi közösségek és az állam feladatát a gyermekek védelmében. (Panduru és mtsai, 2006)

A gyermekvédelem rendszere három szintre tagolható, az országos, a megyei és a helyi szintre. Nemzeti szinten a román kormány két intézményt hozott létre a Gyermeki Jogok Védelmének Nemzeti Hatóságát és a Romániai Örökbefogadási Hivatalt. Megyei szinten a Szociális és Gyermekvédelmi Igazgatóságok látnak el gyermekvédelmi feladatokat. Helyi szinten pedig az önkormányzatok szerveznek szolgáltatásokat. Együttmüködnek a rendőrséggel, nonprofit szervezetekkel, egészségügyi és oktatási intézményekkel a gyermekek védelme érdekében. A helyi önkormányzatok napközbeni ellátást szerveznek, annak érdekében, hogy ne kelljen elválasztani a szülőket és a gyerekeket egymástól.

A reformok előtt a családjukból kiemelt gyerekek 82\%-a hagyományos/formális keretek között müködő intézményben élt. 1997 és 2000 között a gyermekvédelem rendszerének átalakulása következtében a családias körülményeket biztosító intézmények száma megháromszorozódott. (Panduru és mtsai, 2006.)

A 2000 és 2006 közötti időszakban, az intézményekben elhelyezett gyermekek száma évről-évre csökkenő tendenciát mutat.

7. táblázat. Elhelyezési központok Romániában

\begin{tabular}{|l|c|c|c|c|c|c|c|}
\hline $\begin{array}{l}\text { Elhelyezési } \\
\text { központ }\end{array}$ & $\mathbf{2 0 0 0}$ & $\mathbf{2 0 0 1}$ & $\mathbf{2 0 0 2}$ & $\mathbf{2 0 0 3}$ & $\mathbf{2 0 0 4}$ & $\mathbf{2 0 0 5}$ & $\mathbf{2 0 0 6}$ \\
\hline Összes & 738 & 754 & 841 & 1274 & 1369 & 1382 & 1493 \\
\hline Állami & 513 & 508 & 540 & 950 & 983 & 995 & 1100 \\
\hline - Ebből családias & - & - & 242 & 565 & 620 & 678 & 781 \\
\hline Magán & 225 & 246 & 341 & 324 & 386 & 387 & 393 \\
\hline $\begin{array}{l}\text { Gondozásba vett } \\
\text { gyerekek }\end{array}$ & 57181 & 49965 & 43234 & 37660 & 32679 & 28786 & 27188 \\
\hline $\begin{array}{l}\text { Állami } \\
\text { centrumokban }\end{array}$ & 53335 & 45422 & 37781 & 31941 & 27129 & 23684 & 22285 \\
\hline Magán centrumok & 3846 & 4543 & 5453 & 5719 & 5460 & 5102 & 4903 \\
\hline
\end{tabular}

Forrás: Panduru és mtsai (2006): System in support of children without parental care in Romania Bucharest: National Statistical Institute of Statistics. Country Analytical Report prepared for the MONEE Project, UNICEF, IRC 9. o. 
A 7. táblázat adatai szerint 2000-ben 57181 fö volt gondozásban, 2002-ben 43234 fó, 2006-ban pedig már csak 27188 fő élt intézményben. Az intézményes elhelyezés körülményeire jellemzö, hogy kisméretü apartmanokban, családi házakban történik. Ezek úgynevezett elhelyezési központokká szerveződnek. 2006 közepén 1493 elhelyezési központ müködött Romániában, ebböl 1100 állami és 393 magánközpont. Az állami elhelyezési központok több mint fele, 1493-ból 781 családias jellegü. Az állami centrumok mellett magáncentrumok is múködnek, ezek száma növekvő tendenciát mutat a 2000 és 2006 közötti időszakban. Míg 2000-ben 3846 centrum múködött, addig 2006-ban 4903.

A gyerekek életkorát tekintve 2006-ban a legtöbb elhelyezett gyermek a 13-17 éves korosztályból került ki. A romániai szabályok fontos alapelve, hogy 2 éves kor alatt nem kerülhetnek intézménybe a gyerekek. Öket nevelőszülőknél helyezik el.

Romániában különösen magas a gyerekek magára hagyása. 2004-ben 4000 gyereket hagytak a szülészeteken, 100 szülésből 1,8 gyereket elhagynak a szüleik, és 5000 gyereket hagytak kórházakban vagy gyermekosztályokon. (Mykytyn, 2005)

Számos olyan szociális-gazdasági faktor van, ami befolyásolja a gondozásba kerülö gyerekek számát. Az egyik vezető ok a munkanélküliség - az esetek 74 \%- ban - ezt követi az alacsony jövedelem $62 \%$-kal, majd a hajléktalanság, ami az esetek 58\%-ban vezet intézményes elhelyezéshez. A személyes problémák, mint az alkoholizmus, mentális betegségek, a csecsemőotthonokban elhelyezetteknél kb. 20\%-ban szerepel elhelyezési okként. (Papava, 1996)

A családi típusú elhelyezés 2001 és 2006 között növekvő tendenciát mutat. 2005-ben Romániában 76871 gyermek élt a családja nélkül. Közülük 29148 fó elhelyezési centrumokban élt, 47723 fő pedig nevelőszülőknél. (TRANSMONEE, 2007. UNICEF, Innocenti Research Center). Az adatok alapján megállapítható, hogy 2005-re a nevelöszülői elhelyezés vált a domináns elhelyezési formává Romániában.

A nevelőszülői elhelyezést a megyei tanács szervezi és ellenőrzi a Szociális és Gyermekvédelmi Igazgatóságon keresztül. Itt egyéni tervet készítenek a gyerek számára, amelyben rögzítik a gondozás menetét, a feltételeket, amit a nevelöszülönek biztosítani kell, hogy a gyereket az otthonába fogadhassa. (Panduru és mtsai, 2006)

Az intézményi decentralizáció és a nevelőszülői elhelyezés preferálása mellett a kormányzat törekszik az integrált, közösségi alapú segítő szolgáltatások bevezetésére a helyi önkormányzatokon keresztül, mind a 12 megyében. Ezeknek a szolgáltatásoknak az elsődleges célja a családok segítése, a veszélyeztetett gyermekek számának csökkentése annak érdekében, hogy minél kevesebb gyerek kerüljön ki a családjából.

Magyarország gyermekvédelme ugyan ide tartozik, de itt eltekintünk a magyarországi helyzet bemutatásától, mivel a dolgozat további fejezeteiben mind a történeti áttekintés, mind az elhelyezési lehetőségek bemutatása részletesen megtalálható. 


\subsection{Közös vonások és eltérések}

Összehasonlítva a bemutatott országok gyermekvédelmét, két modell rajzolódott ki. Az egyik modellt a nyugat-európai országok alkotják, a másikat a kelet-közép európai országok. A nyugat-európai országok gyermekvédelme sok hasonlóságot mutat. A nyugat-európai országokban is jellemző, hogy a gyermekvédelem intézményesülése elött az egyházak és a helyi közösségek végeztek gyermekvédelmi tevékenységet. Az állami szerepvállalás megerösödésével épült ki a gyermekvédelmi intézmények rendszere a különböző országokban. A II. világháború jelentős hatással volt a gyermekvédelemre, mivel megnőtt az elárvult gyerekek száma a háború miatt. Ez cselekvésre ösztönözte a kormányokat a gyermekek védelme érdekében, féröhelyeket kellett biztosítani számukra. A bemutatott országokban az 1960-as évekig tartották magukat a nagy intézmények. Ekkor indultak el azok a reformfolyamatok, amelyek a gyermekvédelmi intézmények átalakítását előmozdították. A „nevelőotthoni kampány" keretében követelték a diákmozgalmak résztvevői a nevelőotthonok kapuinak a megnyitását, az otthonok átalakítását. (Trede, 1993)

A 70-es évektől kezdve indult meg a nagy intézmények lebontása, kisebb létszámú, 8-15 férőhelyes, családias jellegü lakásotthonok létrehozása révén. A gyermekvédelmi intézményrendszer átalakítása szükségessé vált, ezt mind a megváltozott társadalmi körülmények, mind a gyermekek szükségletei indokolttá tették. A legfontosabb változás az, hogy a nagyméretü bentlakásos intézmények megszüntek: kisebb, önálló egységekre oszlottak, féröhelyszámukat csökkentették, vagy megszüntek. A valaha kisméretü nevelőotthonoknak számító 40-50 fős rendszerek ma már nagy intézetnek minősülnek. A gondozottak csoportjai átlag 8-10 tagot számlálnak az alig néhány évvel ezelőtti 25-30 fő helyett. (Gottesman, 1991)

2. ábra. Gyermekotthonokban és nevelöszülöknél elhelyezett gyerekek aránya az egyes országokban

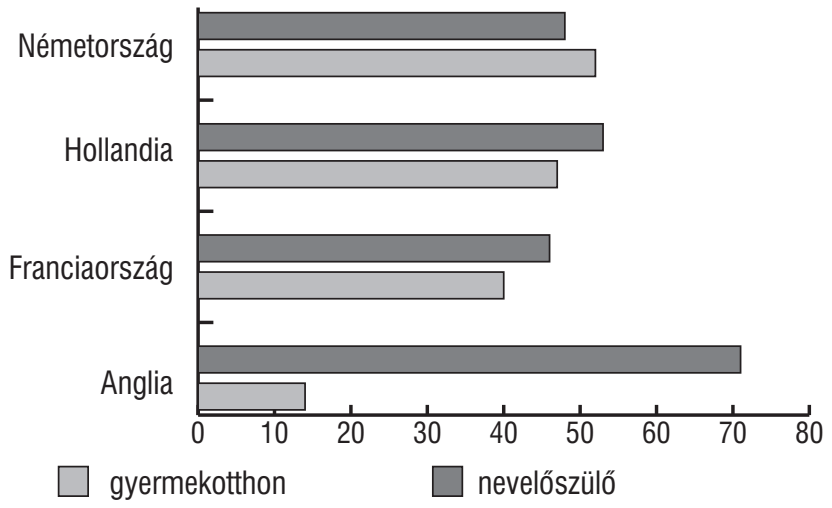

Forrás: Madge N., (1994): Children and residential care in Europe. National Children's Bureau, London. 71.o. 
A fentiekben bemutatottakon túl az intézményrendszer a következö területeken mutat hasonló tendenciákat a nyugat-európai országok gyermekvédelmében: a fenti diagram (2. ábra) alapján megállapítható, hogy valamennyi országban preferálják a nevelőszülői elhelyezést. A legnagyobb mértékben Anglia alkalmazza az intézményes elhelyezés alternatívájaként a nevelőszülői elhelyezést. Itt a gyerekek 71\%-a él nevelőszülöi családban. Németországban a gyerekek közel 50\%-a él nevelőszülőknél, Franciaországban 46\%-uk, Hollandiában 53 \%-uk. (Madge, 1994). Hasonló arányokról számolnak be Pat Petrie (2006) és munkatársai is az európai országok gyermekotthoni nevelését áttekintő munkájukban.

A nevelőszülői elhelyezés előtérbe kerülésének oka lehet a családias körülmények közötti elhelyezés preferálása mellett az is, hogy jobban odafigyelnek a gyerekek és a szülők „hangjára”. Az intézményes nevelés magas költségei, valamint a kutatások is felhívták a figyelmet az intézményes nevelés negatív hatására. (Hellinckx, 2002)

Az ellátórendszert áttekintve megállapítható, hogy a bemutatott országok gyermekvédelme kétszintü. Mindegyik országban (Hollandia, Németország, Anglia, Franciaország) törekednek arra, hogy a szolgáltatásokat megerősítsék, és ezzel a családokat segíteni tudják annak érdekében, hogy gyerekeiket otthonukban nevelhessék. Az intézményes ellátórendszer erőteljesen differenciált.

Míg Németországban az intézmények feladataik alapján osztályozhatóak, addig Franciaországban az osztályozás elsősorban a gyerekek jellemzőiből/szükségleteiből indul ki. (pl. fogyatékkal élők, tanulási zavarral küzdők stb. otthonai). Az intézményes ellátás iránti fokozott érdeklődést Hollandiában a deviáns fiatalok számának növekedése okozza. Hollandia ugyanakkor sajátos abból a szempontból, hogy nagyon sokféle megoldást kínáló nevelőszülői rendszert hoztak létre, a terápiás szülőktől az üdültető családokig széles a paletta. Anglia helyzete pedig azért kivételes, mert a nevelőszülői ellátást itt fejlesztették legkorábban és legnagyobb mértékben.

A gyerekek intézménybe kerülésének okai a különböző országokban sok hasonlóságot mutatnak. Franciaországban négy csoportba oszthatók az otthonba került gyerekek: elhagyottak, átmenetileg valamilyen családi probléma miatt elhelyezettek, fiatalok, akiket a szülők nem tudnak ellátni, nevelni valamint a fiatalkorú bűnelkövetők. Németországban a családi kötelékek szétbomlása miatt került be a gyerekek 37,5 százaléka, 6\% árvaság miatt, 29,5 százalék házasságon kívül született, 27 százalék pedig maga jött el a szülőktől. A többi országban szintén hasonló okok miatt kerülnek intézményes nevelésbe a gyerekek. Egyrészt elhanyagolás, bántalmazás, másrészt a gyerek viselkedése miatt. A szerző szerint a nem állami fenntartóknak jelentős szerepe van a gyermekvédelmi intézmények fenntartásában. Az általunk bemutatott országok közül Németországban 14 \% az állami fenntartású intézmények aránya, 80 \% az egyházi, alapítványi fenntartásúaké. Franciaországban a legtöbb otthont non-profit szervezetek müködtetik, és ki- 
terjedt önkéntes munka is jellemző. Hollandiában szintén a non-profit szervezetek müködtetik az intézmények többségét, állami finanszírozással. Kivétel a sorban az Egyesült Királyság, ahol nem a non-profit szervezetek, hanem a helyhatóságok működtetik a gyermekvédelmi intézményeket. (Madge, 1994)

Az általunk bemutatott nyugat-európai országok közül valamennyi megalkotta a gyermekvédelmi törvényét, és ezek folyamatos módosításával látják el a feladatukat. Franciaországban, 1984-ben, Hollandiában 1989-ben, Angliában 1989-ben, Németországban 1990-ben fogadták el a gyermekvédelmi törvényt.

A kelet-közép-európai országok alkotják a másik modellt. A nyugat-európai országokhoz hasonlóan a gyermekvédelmi intézmények kialakulását itt is megelőzte az egyházak és a helyi közösségek gyermekvédelmi tevékenysége. Az állami gyermekvédelmi intézmények születése azonban jóval később történt meg, mint a nyugat-európai országokban. Ennek oka, hogy a kelet-közép-európai országok „megkésettek” a nyugat-európai országokhoz képest. A megkésettség lemaradást jelent, a nyugat európaitól eltérő fejlődést eredményezett mind az iparosodás, mind a polgárosodás tekintetében. A II. világháború a kelet-közép-európai országokban is nagy véráldozatokat követelt.

Ennek következtében az árván maradt gyerekek ellátását biztosítani kellett. Az általunk vizsgált országok gyermekvédelme több hasonlóságot mutat. Ezekben az országokban az államszocializmus idején hittek abban, hogy az intézményes, közösségi elhelyezés a legmegfelelöbb a gyerekek számára. Ezért az intézményekben megvalósuló állami gondozás volt a gyerekek ellátásnak a legelfogadottabb módja. Jellemző volt valamennyi országban a nagy intézmények müködtetése. Az otthonok müködési feltételei nagyon különbözőek, a legrosszabb helyzetben az elhagyott gyerekek és a csecsemők éltek. A legjobb otthonok is szenvedtek a túlmedikalizációtól.(UNICEF, 1997.)

A rendszerváltás évei számos változást hoztak a gyermekvédelem területén ezekben az országokban. Az átmenet éveiben nőtt azoknak a családoknak a száma, amelyek elszegényedtek, munkanélkülivé váltak és nem tudták a megfelelő gondozást biztosítani a gyerekeiknek. Ennek következtében nőtt az intézményben elhelyezett gyerekek száma. 
8. táblázat. Állami gondozásban részesülő gyerekek száma 1989-1995 (100.000 gyerekre vetítve)

\begin{tabular}{|l|c|c|c|c|c|c|c|c|}
\cline { 2 - 9 } \multicolumn{1}{c|}{} & $\mathbf{1 9 8 9}$ & $\mathbf{1 9 9 0}$ & $\mathbf{1 9 9 1}$ & $\mathbf{1 9 9 2}$ & $\mathbf{1 9 9 3}$ & $\mathbf{1 9 9 4}$ & $\mathbf{1 9 9 5}$ & $\begin{array}{c}\text { Különbség } \\
\mathbf{1 9 8 9} \text { és } \\
\mathbf{1 9 9 5} \text { között }\end{array}$ \\
\hline Csehország & 867,3 & 866,7 & 887,8 & 909,8 & 965,4 & 1027,0 & - & 159,0 \\
\hline Szlovákia & 843,3 & 820,2 & 843,3 & 866,6 & 891,8 & 908,0 & - & 64,7 \\
\hline Magyarország & 889,3 & 845,5 & 790,4 & 776,5 & 768,9 & 772,9 & 786,6 & $-102,7$ \\
\hline Románia & - & - & 1518,7 & 1357,5 & 1637,6 & 1880,1 & - & 258,8 \\
\hline Lengyelország & 924,0 & 947,1 & - & 954,7 & 999,9 & 1021,8 & - & 97,8 \\
\hline
\end{tabular}

Forrás: UNICEF (1997): Children at risk in Central and Eastern Europe: perils and promises, Florence Italy 69. o.

A 8. táblázat adatai alapján megállapítható, hogy az általunk bemutatott országok többségében, így Romániában, Csehországban, Lengyelországban és Szlovákiában is nőtt az intézményben elhelyezett gyerekek száma az 1989-1995-ös időszakban. A trend alól Magyarország kivételt képez. Nálunk az intézményben elhelyezett gyerekek száma csökkenő tendenciát mutat. Ennek oka, hogy az átmenet kevésbé zúzta szét a szociális értéket és a családok küzdési stratégiáját. A gazdasági és politikai reformok 1989 előtt kezdődtek, és bevezettek egy erős univerzális családtámogató politikát, ami segíti a családokat megmenteni az összeomlástól. Relatíve fejlett a családsegítő hálózat, ami segítséget jelent a családoknak. (UNICEF, 1997)

A kelet-közép európai országok sajátossága, hogy a nyugat-európai országok mintaként szolgálnak számukra a gyermekvédelem területén is. Az általuk nyújtott minta a '80-as években kezd megjelenni az említett országokban. A kelet-középeurópai országok gyermekvédelmi intézményeinek áttekintése nyomán a következő megállapítást tesszük.

A rendszerváltás utáni években ezekben az országokban is - hasonlóan a nyugat-európaiakhoz - kétszintủ gyermekvédelmi rendszer létrehozására törekedtek. Lengyelországban, Magyarországon, Csehországban, Szlovákiában és Romániában vagy már létrejöttek olyan alapszolgáltatások, amelyek a családokat segítik, vagy a kormányzat ezek megerősítésére törekszik. Ott, ahol ez nem sikerül, a gyermek intézményes ellátásba kerül. Mára a legtöbb kelet-közép-európai ország átalakította gyermekvédelmi intézményrendszerét. A nevelöszülői elhelyezés ezekben az országokban is elötérbe kerül a gyerek elhelyezésének sorrendjében. Jellemző azonban, hogy a nevelőszülői elhelyezés még nem öltött olyan méreteket, mint a nyugat-európai országokban. 
9. táblázat. Gyermekvédelmi gondoskodásban részesülö gyerekek 2005

\begin{tabular}{|l|c|c|c|c|}
\cline { 2 - 5 } \multicolumn{1}{c|}{} & $\begin{array}{c}\text { Gyermekotthonban } \\
\text { elhelyezett gyerekek }\end{array}$ & $\begin{array}{c}\text { Bentlakásos } \\
\text { iskolában } \\
\text { elhelyezett } \\
\text { gyerekek }\end{array}$ & $\begin{array}{c}\text { Nevelöszülőknél } \\
\text { elhelyezett } \\
\text { gyerekek }\end{array}$ & Összesen \\
\hline Csehország & 23472 & 2752 & 8988 & 32460 \\
\hline Románia & 29148 & - & 47723 & 76871 \\
\hline Szlovákia & 8977 & 1432 & 3250 & 12227 \\
\hline Lengyelország & 55765 & -- & 49667 & 105432 \\
\hline Magyarország & 8052 & - & 9307 & 17357 \\
\hline
\end{tabular}

Forrás: TRANSMONEE 2007 Features. UNICEF, Innocenti Research Center 47.o.

A 9. táblázat adatai alapján látható, hogy Csehországban, Szlovákiában, Lengyelországban még több gyermek él gyermekotthonban, mint nevelöszülőnél. Magyarországon és Romániában a nevelőszülői elhelyezés került túlsúlyba. Jelentősen több gyermek él Romániában nevelöszülönél - 47723 fö -, mint gyermekotthonban, ami 29148 föt jelent.

Miközben az intézmények küszködnek a növekvő költségekkel, tanulmányok sora igazolja, hogy az intézményes nevelés szignifikánsan drágább, mint az alternatív családi szolgáltatások. Összehasonlítva az elhelyezési lehetőségeket, a nevelöszülöi gondozás költsége kb. egyharmada, egyötöde az intézményi elhelyezés költségének. A családot támogató szociális szolgáltatások pedig kb. egynyolcadába kerülnek. (Carter, 2005)

A kutatások szerint a legtöbb gyerek a szegénység, a fogyatékosság, az etnikai hovatartozás, valamint a szülők elhanyagolása miatt kerül gondozásba. A kelet-közép -európai országok sajátossága, hogy az etnikai hovatartozás fontos faktor az intézménybe kerülés szempontjából. Különösen veszélyeztetett ebből a szempontból a cigányság. Magyarországon a népesség $5 \%$ - a roma, a gondozásba került gyerekek 60\%-a roma. Csehországban és Szlovákiában még magasabb ez az arány, 65 \%. A cigánygyerekek körében növeli a gondoskodásba kerülés kockázatát a nagycsalád, az alacsony jövedelem, a magas munkanélküliségi ráta. (UNICEF 1997)

A legnagyobb problémát azonban mindenütt az intézményrendszer és a finanszírozás nehézkessége jelenti. Az országok lépéseket tettek az ellátórendszer átalakítására a nyugat-európai országok mintájára. A kisebb, családiasabb otthonok létrehozására törekednek, de ennek finanszírozása drágább, ráadásul az elmúlt években a gyerekek teljes ellátásának költsége nőtt.

A kelet-közép-európai országokban is törvényekkel szabályozzák a gyermekvédelmet. A törvények megalkotását segítette az ENSZ Gyermeki Jogok Egyezményének a megjelenése 1989-ben. Romániában, 2004-ben, Szlovákiában 2005-ben 
módosították a gyermekvédelmi törvényt. Lengyelországban az 1990-ben megalkotott szociális törvény, Magyarországon az 1997-ben ratifikált gyermekvédelmi törvény, Csehországban az 1998-ban megalkotott családjogi törvény tartalmazza a gyermekek védelmére vonatkozó szabályokat. 


\section{A GYERMEKVÉDELEM RENDSZERE MAGYARORSZÁGON}

A fejezetben a gyermekek elhelyezésének lehetőségeit mutatjuk be a következő szempontok alapján. Összehasonlítjuk az 1997-es évi XXXI. Gyermekek védelméről és a gyámügyi igazgatásról szóló törvény bevezetése előtti és utáni gyermekvédelmi szolgáltatásokat, és a jelenlegi helyzet elemzésére teszünk kísérletet. Az elemzés során összefoglaljuk, hogy milyen változások következtek be az intézményekben elhelyezett gyerekek életkörülményeiben az elmúlt években.

A gyermekvédelmi intézmények részben családi funkciókat vesznek át, részben pedig korrigálják a családjukból kikerült gyerekek szociális helyzetét, pszichés állapotát. A gyermekvédelmi tevékenységnek különböző szintjei vannak. Ezek a következők. A szociálpolitikai szint - a szociális szükségletek elismerését, a gyermekvédelmi ellátórendszer szintje - a célcsoport és az ellátások (jogszabályban rögzített) meghatározását, az intézmények szintje - a gyermekek problémák szerinti csoportosítását (saját arculat), a kapcsolódó feladatot teljesítők, társintézmények szintje -szolgáltatásaikat, a munkatársak szintje - a szaktudás, a tapasztalatok, a módszerek és a készségek alkalmazását, a gyermekek szintje - az egyéni jellemzőiket, problémaskálájukat jelenti. (Domszky, 2004)

Ezek a szintek a gyermekvédelem szereplöit is jelentik, amelyek a következö csoportokba sorolhatók. Az első a szociálpolitika, amelynek részét képezik a gyermekvédelem keretében müködő gyermekvédelmi intézmények az általuk nyújtott szolgáltatásokkal. A második csoportot a gyermekvédelemben dolgozók alkotják, akik a szolgáltatásokat biztosítják szaktudásuknak megfelelően. A harmadik csoportba azok a gyerekek tartoznak, akiknek az ellátását, gondozását a család nem tudja biztosítani. A gyermek családból való kiemelését megelözi a gyermekjóléti szolgálatok segítő tevékenysége. Ha ez nem hoz eredményt, csak akkor lehet a gyereket kiemelni a családból. A döntés meghozatala több szakember együttes munkájának az eredménye.

A rendszer változásának hatására a döntések jóval megalapozottabbak lettek, mint korábban, amikor egy ügyintéző hozott döntést. '97 elött ugyanis a gyermek kiemeléséről a gyámhivatali ügyintéző döntött egy személyben. A család segítő szolgáltatásokat nem kapott a problémái megoldásához, ehhez nem is állt rendelkezésre intézmény. A családból kiemelt gyermek elhelyezése során a törvény preferálja a családba való visszahelyezést, a nevelőszülői ellátást vagy örökbefogadást és sorrendben utolsóként a gyermekotthoni elhelyezést. Mindez azt a célt szolgálja, hogy a gyerek családias körülmények között éljen akkor is, ha ez a saját családjában nem lehetséges. A törvény bevezetése előtt elsősorban 
nevelőotthonokban helyezték el a gyerekeket. A dolgozat további részében a család nélkül élő gyerekek elhelyezési lehetőségeit mutatjuk be.

10. táblázat. Gyermekvédelmi gondoskodásba vett gyerekek gondozási helye

\begin{tabular}{|c|c|c|c|c|}
\hline Évszám & $\begin{array}{c}\text { Gyermekvédelmi } \\
\text { gondoskodásban } \\
\text { élök összesen }\end{array}$ & $\begin{array}{c}\text { Intézményben } \\
\text { és egyéb helyen } \\
\text { elhelyezettek }\end{array}$ & $\begin{array}{c}\text { Nevelőszülőnél } \\
\text { elhelyezettek }\end{array}$ & $\begin{array}{c}\text { Nevelőszülőnél } \\
\text { elhelyezettek } \\
\text { az összes nevelt } \\
\text { \%- ban }\end{array}$ \\
\hline $\mathbf{1 9 9 0}$ & 25177 & 16610 & 8567 & 34 \\
\hline $\mathbf{1 9 9 5}$ & 20066 & 12379 & 7687 & 38 \\
\hline $\mathbf{1 9 9 6}$ & 19688 & 12185 & 7503 & 38 \\
\hline $\mathbf{1 9 9 7}$ & 18949 & 11454 & 7495 & 40 \\
\hline $\mathbf{1 9 9 8}$ & 17875 & 10451 & 7424 & 42 \\
\hline $\mathbf{2 0 0 3}$ & 17074 & 8466 & 8608 & 50 \\
\hline $\mathbf{2 0 0 4}$ & 16847 & 8207 & 8640 & 51 \\
\hline $\mathbf{2 0 0 5}$ & 16671 & 7842 & 8829 & 53 \\
\hline
\end{tabular}

Forrás: Tájékoztató a család, gyermek- és ifjúságvédelem helyzetéröl SZMM Gyermek- és ifjúságvédelmi föosztály 2006. 80. o.

A gyermekvédelmi szakellátásban élők száma folyamatosan csökken. (10. táblázat). Míg 1990-ben 25177 fö, addig 1998-ban 17875 fö, 2005-ben pedig 16671 fő részesült gyermekvédelmi szakellátásban. Az adatokból az is látszik, hogy a gyermekvédelmi törvény bevezetése utáni némileg csökkent a bekerülő gyerekek száma, de nem a felével, mint ahogy azt a törvény bevezetésétől várták. A gyerekek gondozási hely szerinti megoszlása is változást mutat, ismét több gyerek kerül nevelőszülőknél elhelyezésre. 1990-ben a gyerekek 34 \%- a élt nevelöszülöknél, 1998-ban már 42\%-uk, 2005-ben pedig már több, mint az elhelyezett gyerekek fele, 53\%. Ezzel párhuzamosan csökken a gyermekvédelmi intézményekben élők száma. 1990-ben 16610 fö, 1998-ban 10451 fó, 2005-ben pedig 7842 fó élt intézményi körülmények között. Láthatóan a gyermekvédelmi törvény fö törekvése, a gyerekek családias körülmények között való elhelyezése kezd megvalósulni. Ez azt jelenti - ahogy az adatokból is láttuk-, hogy az intézménybe kerülő gyerekeket elsősorban nevelőszülői családban próbálják elhelyezni. A szakemberek között ma is vita tárgyát képezi, hogy mi a legjobb elhelyezési forma a gyermeknek. Egyes megközelítések szerint fel kellene számolni a gyermekotthonokat, és kizárólag nevelőszülőknél elhelyezni a gyermekeket.

Ezzel az elgondolással nem értünk egyet, véleményünk szerint szükség van mind a nevelőszülői, mind a gyermekotthoni elhelyezésre. Minél több lehetőséget 
kínál az ellátórendszer, annál valószínübb, hogy a gyermekek szükségleteinek legmegfelelőbb ellátást lehet nyújtani.

Az általunk összeállított alábbi összehasonlító táblázatban azokat az intézményeket tekintjük át és vetjük össze, amelyek a családjukból kiemelt gyermekek elhelyezésére szolgáltak/szolgálnak az 1997 előtti és utáni időszakban.

Személyes gondoskodást nyújtó intézmények

\begin{tabular}{|c|c|}
\hline 1997 előtt & 1997 után \\
\hline Csecsemőotthonok & $\begin{array}{l}\text { Átalakult, helyette különleges gyermekotthonok } \\
\text { biztosítják a } 0-3 \text { éves korosztály ellátását. }\end{array}$ \\
\hline Óvodás korú gyermekek otthonai (3-6 év) & $\begin{array}{l}\text { Megszüntek, a 3-6 éves korosztály elhelyezése } \\
\text { nevelőszülőknél, gyermekotthonokban, } \\
\text { lakásotthonokban valósul meg. }\end{array}$ \\
\hline Általános iskoláskorú tanulók otthonai (6-14 év) & $\begin{array}{l}\text { Megszüntek, a 6-14 éves korosztály ellátása } \\
\text { nevelőszülőknél, gyermekotthonokban, } \\
\text { lakásotthonokban koedukált, vegyes életkorú } \\
\text { csoportokban történik. }\end{array}$ \\
\hline Ifjúsági otthonok (14 év fölött) & $\begin{array}{l}\text { Megszüntek, a fiatalok elhelyezése } 24 \text { éves } \\
\text { korig nevelőszülőknél, gyermekotthonokban, } \\
\text { lakásotthonokban, koedukált, vegyes életkorú } \\
\text { csoportokban történik. }\end{array}$ \\
\hline Túlkoros gyerekek nevelőotthonai (9-18 év) & $\begin{array}{l}\text { A túlkoros gyerekek elhelyezése nem különül } \\
\text { el, nevelöszülöknél, gyermekotthonokban, } \\
\text { lakásotthonokban koedukált, vegyes életkorú } \\
\text { csoportokban történik. }\end{array}$ \\
\hline $\begin{array}{l}\text { Speciális nevelőotthonok, neurotikus, } \\
\text { antiszociális magatartású gyerekek számára }\end{array}$ & $\begin{array}{l}\text { Speciális gyermekotthonok, az antiszociális, } \\
\text { disszociális tüneteket mutató, pszichotrop } \\
\text { szerhasználók számára. }\end{array}$ \\
\hline $\begin{array}{l}\text { Javítóintézetek: a fiatalkorúak bírósága által } \\
\text { javító nevelésre utalt fiatalok elhelyezése min. } \\
1 \text { év. }\end{array}$ & $\begin{array}{l}\text { Javító-nevelő intézet a bíróság által } \\
\text { javítóintézeti nevelésre utalt, illetve az } \\
\text { előzetes letartóztatásba helyezett fiatalkorúak } \\
\text { elhelyezése megmaradt. }\end{array}$ \\
\hline $\begin{array}{l}\text { Nevelőszülői hálózat '80-as évektől felerősödött } \\
\text { a támogatottsága. } 1986 \text { a hivatásos nevelőszülői } \\
\text { hálózat kiépítésének kezdete. }\end{array}$ & $\begin{array}{l}\text { A családias elhelyezés biztosítása érdekében } \\
\text { preferált elhelyezési forma. Hagyományos, } \\
\text { hivatásos, speciális hivatásos nevelőszülők } \\
\text { száma növekszik. }\end{array}$ \\
\hline $\begin{array}{l}\text { A hivatásos pártfogó feladata a nevelőintézetböl } \\
\text { való kikerülés után a gyermek sorsának } \\
\text { figyelemmel kísérése. Utógondozó otthon nem } \\
\text { müködik. }\end{array}$ & $\begin{array}{l}\text { Utógondozó otthonok a nagykorúvá vált } \\
\text { fiatal felnőttek társadalmi beilleszkedésének } \\
\text { segítésére. }\end{array}$ \\
\hline Gyermek- és Ifjúságvédő Intézet (GYIVI) & $\begin{array}{l}\text { Területi Gyermekvédelmi Szakszolgálat } \\
\text { (TEGYESZ) }\end{array}$ \\
\hline Nevelöotthon & Gyermekotthon, lakásotthon \\
\hline
\end{tabular}

A fenti áttekintő táblázat alapján látható, hogy 1997 előtt az óvodáskorú 3-6 éves gyermekeket óvodás gyermekotthonba helyezték el. Óvodai nevelésben részesül- 
tek az intézményen belül müködő óvodában. Az általános iskolás korú tanulók otthonában a tanulókat az intézmény belső iskolájában oktatták. Többféle általános iskolai otthon müködött, voltak olyan otthonok, ahová csak alsós vagy csak felső tagozatos diákok kerültek elhelyezésre. Nagy változás, hogy 1997 után az életkorukat tekintve nem különítik el a gyermekeket. Jellemző, hogy a létrehozott otthonokban vegyes életkorú, koedukált gyermekcsoportok müködnek, mert ez élet- és családszerü. A törvény fontosnak tartja a testvérek együttes elhelyezését, ez egy vegyes életkorú gyermekeket ellátó rendszerben könnyebben megvalósítható.

Megszüntek viszont a gyermekvédelmi törvény bevezetése előtt müködő ifjúsági otthonok. Ezekben azokat az állami nevelt gyermekeket helyezték el, akik általános iskolai tanulmányaikat befejezték. Mezőgazdasági és ipari ifjúsági otthonként müködtek. Az ifjúsági otthonban elhelyezett fiatalok szakmunkás végzettséget szereztek. 1997 után ilyen jellegü otthonokat nem müködtetnek. A továbbtanuló fiatalok kollégiumokban, diákotthonokban kerülnek elhelyezésre, akik a hétvégét a gyermekotthonban, lakásotthonban töltik.

A túlkoros gyermekek nevelőotthonaiban a 9-18 éves gyermekek elhelyezésére került sor, akik két vagy több évvel elmaradtak a korosztályuktól a tanulmányaik teljesítésében. A tanulókat életkoruktól, képességeiktől függően „,belső iskolában”, elkülönítetten oktatták 10-15 fős csoportokban. Az otthonok célja az osztályozó vizsgára való előkészítés, iskolai oktatás. Ebben az otthontípusban biztosították, hogy az általános iskolai tanulmányaiban több évvel elmaradt és szakmai képzésre alkalmas állami gondozott gyermekek szakmai képzésüket és általános iskolai tanulmányaikat is befejezhessék. A törvény bevezetése után ezeket a gyerekeket nem elkülönítetten nevelik.

Speciális nevelőotthonok müködtek a törvény bevezetése előtt is. Ilyen otthonokban elsősorban a neurotikus és az antiszociális magtartású gyermekek számára biztosítottak ellátást. A speciális nevelőotthonok korrekciós neveléssel, terápiás eljárásokkal készítették elő a gyermekeket a nevelőotthonba való visszatérésre.

A gyermekvédelem rendszerének átalakítása az intézmények sokszínüségét eredményezte. Megjelentek a különleges, speciális, utógondozó otthonok, amelyek korszerübb tartalommal müködnek, mint az 1997 előtti intézmények. Jelentős probléma viszont, hogy ezeknek az intézményeknek kevés a száma. A speciális ellátást igénylők ellátása nehézségekbe ütközik a férőhelyek hiánya miatt.

Az intézményekben élő gyerekek társadalmi integrációját segítette a belső iskolák, a korcsoportonkénti elkülönítés megszüntetése. Ezzel lehetővé vált, hogy a gyerekek egy intézményben töltsék diákéveiket, így szorosabb kapcsolatot tudnak kialakítani nevelöikkel, diáktársaikkal.

A következőkben a gyerekek elhelyezését biztosító intézményeket mutatjuk be. 


\subsection{Csecsemőotthon}

A 60-as évektöl kezdve változó számú, 25-40 csecsemőotthon müködött Magyarországon, ami a 0-3 éves korú gyermekek elhelyezésére szolgált. Itt elsősorban állami nevelésbe vett gyermekeket helyeztek el, néhány intézményben lehetőség volt a csecsemő és az anya együttes elhelyezésére is. Számukra azonban nem nyújt megoldást az intézményes nevelés. A megelőző felkészítés, a nem kívánt terhességek elkerülése, a család alkalmassá tétele a gyermek vállalására szinte teljes mértékben kiválthatóvá tenné a ma müködő 27 csecsemőotthont. Ez így van a fejlett világ országainak túlnyomó többségében. Ök ezen intézményeket két évtizeddel ezelött már megszüntették. (Herczog, 1997)

3. ábra. Csecsemöotthoni féröhelyek alakulása

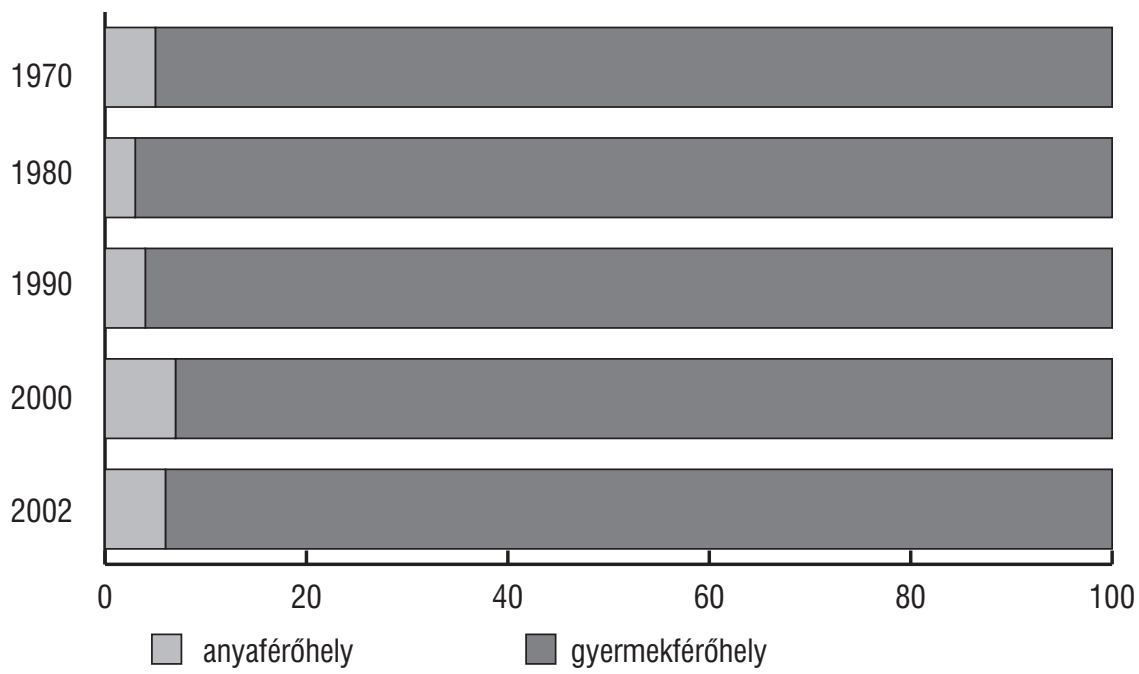

Forrás: Tóth Judit Nikoletta (Szerk.)(2004): A gyermekvédelmi szakellátás helyzete a XX. században KSH, Budapest, 18. o.

A gyermekvédelmi törvény bevezetése után csökkent a csecsemőféröhelyek aránya, az anyaférőhelyek számát pedig bővítették. (3. ábra) A KSH adatai szerint, amíg 1990-ben 3690 csecsemő és 144 anya számára volt férőhely az otthonokban, addig 2002-ben 1399 csecsemő és 94 gyermekférőhellyel számolhatunk. Arányait tekintve az anyaférőhelyek száma közel kétszeresére nőtt. Ezzel együtt a csecsemőotthonokat folyamatosan átalakították Magyarországon. A 0-3 éves korosztály a különleges gyermekotthonokban kerül elhelyezésre. 
A gyermekotthonok abban az esetben fogadhatják be a 0-3 éveseket, ha az elhelyezésükhöz szükséges feltételeket biztosítani tudják.

A különleges gyermekotthonban kerülnek elhelyezésre a koruk miatt (0-3 éves) különleges ellátást igénylő gyerekek, a tartósan betegek és a fogyatékkal élők. Ez az intézmény vállalja a 6 éven aluli, fogyatékos és részterületen fejlődési elmaradást mutató gyermekek korai fejlesztését, gondozását, a képzési kötelezett gyermekek gondozását, fejlesztő felkészítését, amennyiben ennek tárgyi és személyi feltételeivel rendelkezik. (Büki, 2004)

11. táblázat. Gyermeklétszám alakulása a csecsemőotthonokban 2005

\begin{tabular}{|c|c|c|c|c|c|c|c|c|c|c|c|c|c|}
\hline \multirow{2}{*}{\multicolumn{2}{|c|}{ Megnevezés }} & $\mathbf{0}$ & 1- 2 & 3-5 & $6-11$ & $\begin{array}{l}12- \\
17\end{array}$ & $\begin{array}{l}18- \\
23\end{array}$ & 2 & 3 & 4 & 5 & $\begin{array}{l}6 \text { éves } \\
\text { és idó- } \\
\text { sebb }\end{array}$ & \multirow[t]{2}{*}{ Összesen } \\
\hline & & \multicolumn{6}{|c|}{ Életkor: hónapban } & \multicolumn{5}{|c|}{ Életkor: évben } & \\
\hline \multicolumn{2}{|c|}{$\begin{array}{l}\text { Előző év december 31-i } \\
\text { gyermeklétszám }\end{array}$} & 15 & 33 & 65 & 106 & 86 & 66 & 130 & 105 & 62 & 48 & 273 & 989 \\
\hline \multicolumn{2}{|c|}{ Tárgyévi létszámnövekedés } & 218 & 75 & 63 & 75 & 55 & 44 & 70 & 35 & 19 & 16 & 105 & 775 \\
\hline \multirow{6}{*}{ Ebből: } & Vérszerinti szülőtől & 17 & 17 & 31 & 46 & 36 & 37 & 57 & 23 & 12 & 14 & 69 & 359 \\
\hline & Nevelőszülőtől & & 1 & & & 1 & & 1 & 2 & 3 & & 6 & 14 \\
\hline & $\begin{array}{l}\text { Kórházból (újszü- } \\
\text { lött) }\end{array}$ & 197 & 49 & 19 & 24 & 6 & 3 & 3 & 4 & 1 & & & 306 \\
\hline & $\begin{array}{l}\text { Más gyermekott- } \\
\text { honból }\end{array}$ & & 4 & 4 & 2 & 6 & & 2 & 2 & & 1 & 20 & 41 \\
\hline & $\begin{array}{l}\text { Átmenti ottho- } \\
\text { nokból }\end{array}$ & & & & & 2 & 3 & 3 & 2 & 2 & & 8 & 20 \\
\hline & Egyéb & 4 & 4 & 9 & 3 & 4 & 1 & 4 & 2 & 1 & 1 & 2 & 35 \\
\hline \multicolumn{2}{|c|}{ Tárgyévi létszámcsökkenés } & 11 & 70 & 78 & 98 & 86 & 65 & 104 & 88 & 57 & 29 & 183 & 869 \\
\hline \multirow{6}{*}{ Ebből: } & Szülőhöz, rokonhoz & 7 & 32 & 33 & 39 & 24 & 24 & 40 & 29 & 13 & 3 & 102 & 346 \\
\hline & Nevelőszülőhöz & & 24 & 28 & 35 & 34 & 20 & 44 & 32 & 17 & 15 & 21 & 270 \\
\hline & Örökbe adták & 1 & 7 & 11 & 19 & 20 & 19 & 12 & 9 & 11 & 6 & 6 & 121 \\
\hline & $\begin{array}{l}\text { Más gyermekott- } \\
\text { honba }\end{array}$ & 1 & 7 & 4 & 4 & 6 & 2 & 4 & 16 & 10 & 5 & 30 & 89 \\
\hline & Meghalt & & & & & 1 & & 1 & & 2 & & & 4 \\
\hline & Egyéb & 2 & & 2 & 1 & 1 & & 3 & 2 & 4 & & 24 & 39 \\
\hline \multicolumn{13}{|c|}{ Tárgyév december 31-én nyilvántartott létszám } & 895 \\
\hline
\end{tabular}

Forrás: Tájékoztató a család, gyermek- és ifjúságvédelem helyzetéröl SZMM Gyermek- és ifjúságvédelmi föosztály 2006. 64. o.

2005-ben 895 fő 0-6 éves korú gyerek élt csecsemőotthonokban. (11. táblázat). A bekerülés a 0-2 hónapos korosztály körében leginkább a kórházakból történik az otthonokba, ez 11 hónapos korig jellemző tendencia, 11 hónapos kortól a vérszerinti családból kerülnek be a gyerekek. A csecsemőotthonokból való kikerü- 
lés útjai a saját családba való visszahelyezés, a nevelőszülői elhelyezés, esetleg az örökbefogadás lehet. 2005-ben 869 gyerek került ki a csecsemőotthonból. Közülük 346 föt szülőkhöz vagy vér szerinti rokonokhoz, 270 föt nevelöszülőkhöz helyeztek el, 121 föt pedig örökbe adtak. Ezek az adatok tükrözik annak a törekvésnek a megvalósulását, hogy a korai életkorban a gyerekeknek a családban való elhelyezés a legmegfelelőbb. Amint utaltunk rá, a törvény szerint is elsődleges cél a gyerek saját családjába való visszahelyezése, vagy ha ez nem lehetséges, a nevelöszülőkhöz való elhelyezése, örökbeadása. Az intézményes elhelyezés csak utolsó lehetőségként merül fel a 0-6 éves korosztály körében.

A kutatók a DAPHNE program keretében vizsgálták a 3 év alatti korosztály intézményes elhelyezésének okait, körülményeit. Az intézményes gondozás mindenütt jellemző a WHO Európai régiójában található országokban. Szám szerint kb. 43.842 fö 3 éven aluli gyermek él valamilyen otthonban. Azok a gyermekek hozzák be a pszichikai és értelmi lemaradásukat, akik az intézményekből 6 hónapos koruk előtt családba kerülnek. A családok életében lehetnek olyan veszélyeztető tényezők, amelyek szükségessé teszik az intézményes gondozást. De a gyerekeknek minél előbb az eredményesebb és hatékonyabb nevelöszülökhöz kellene kerülniük. (Browne, 2006)

A következő a speciális nevelőotthon, melyet 1997-től a speciális gyermekotthonok váltottak fel. Ez az intézmény a súlyos pszichés vagy diszociális tüneteket mutató, illetve pszichoaktív szerekkel küzdö gyermekeknek nyújt gondoskodást. Jelenti a szocializációt, esetleg a reszocializációt, valamint habilitációt és rehabilitációt. Jellemző, hogy ide már más gyermekotthonokból kerülnek a gyerekek magatartási problémák, büncselekmények elkövetése miatt. Speciális gyermekotthonban a gyermek teljes körű ellátása csak ritkán haladhatja meg a két évet. Ezekben az intézményekben 40 gyerek elhelyezésére van lehetőség, elkülönítetten a problématípusnak megfelelően.

12. táblázat. Féröhelyek és gyermekek száma az ellátás típusa szerint 2005

\begin{tabular}{|l|c|c|c|c|c|c|}
\hline Megnevezés & $\begin{array}{l}\text { Férő- } \\
\text { helyek } \\
\text { száma }^{\text {a) }}\end{array}$ & $\begin{array}{l}\text { Átmeneti } \\
\text { nevelt }\end{array}$ & $\begin{array}{l}\text { Tartós } \\
\text { nevelt }\end{array}$ & $\begin{array}{l}\text { Utógondozói } \\
\text { ellátásban } \\
\text { részesülö }\end{array}$ & Összesen & $\begin{array}{l}\text { Ebből } \\
\text { leány }\end{array}$ \\
\hline Esztergom & 64 & 53 & 5 & & 58 & 58 \\
\hline Kalocsa & 80 & 41 & 2 & 2 & 45 & \\
\hline Zalaegerszeg & 32 & 30 & 3 & & 33 & \\
\hline Összesen & 176 & 124 & 10 & 2 & 136 & 58 \\
\hline
\end{tabular}

a) Az anyaféröhelyek száma nélkül

Forrás: Tájékoztató a gyermek- és ifjúságvédelem helyzetéröl 2006. 68. o. 
Magyarországon az ágazati minisztérium fenntartásában, Esztergomban, Kalocsán és Zalaegerszegen müködik speciális gyermekotthon. 2005-ben összesen 176 férőhely állt rendelkezésre és 136 gyerek került elhelyezésre. (12. táblázat) Az elhelyezettek többsége fiú, az, akiknek a jogi státusza átmenti nevelt volt, 124 fó. A korábbi években végzett vizsgálatok szerint ezekben az intézményekben nincs megfelelő speciális pedagógiai program és terápiás közösség. Hiányoznak az erre a célra felkészített szakemberek, akik segítenék a helyben megoldhatatlan nevelési problémák megoldását, és ami indokolná, hogy a gyerekeket lakóhelyüktől, sőt megyéjüktől távol, intézményváltással ,gyógyítsák”. (Herczog, 2001)

\subsection{Gyermekotthon, lakásotthon, utógondozó otthon}

Már a '60-as években is problémaként merült fel a nevelöotthonok differenciálatlansága, a nevelés nem lehetett folyamatos, mivel a különböző életkorú gyerekeket különböző intézményekben látták el. Ennek a problémának a megoldására a 3-18 éves gyermekeket nevelő gyermekvárosok létrehozását javasolták a szakemberek. Ahogy az előző fejezetben bemutattuk, így jött létre a fóti, a soponyai, a berettyóújfalui gyermekváros.

A 60-as években a gyermekotthonok között óvodás, általános iskolás, fiú, lány otthonok voltak, szám szerint 125 intézmény. 11 ifjúsági otthon és három javítónevelőintézet müködött Magyarországon. Az otthonokban 14078 fő került elhelyezésre 1968-ban.

A 70-es években újabb probléma merült fel, mert a bekerülő gyermekek összetétele jelentősen megváltozott. Az állami gondozottak száma nemcsak mennyiségi, de minőségi összetételben is negatív irányban változik. Ekkor vette kezdetét a napjainkban is érezhető - belső feszültségeket növelö- antiszociális, erkölcsi fogyatékos, bünözö, narkotizáló gyermekek törvényes behelyezése az otthonokba. Az életkori összetétel is változik, emelkedik a „tizenéves” beutaltak, ezen belül is a 14-18 éves korúak száma. (Dobos, 1986)

A bekerülő gyermekek összetételének változása megkívánta, hogy a nevelöotthonokat korszerüsítsék, a szakmai munkában pedig azt, hogy az egyéni bánásmódot, az önálló életre való felkészítést előtérbe helyezzék. Hanák már 1978-ban figyelmeztetett arra, hogy nem lehet eredményes a gyermekvédelmi munka olyan intézményekben, ahol egy gyermekotthonba kerültek az árva, az elhagyott, a család anyagi elesettsége miatt gondozásba vett, az imbecillis, a mozgásképtelen, a káros szülői környezetből kiragadott és a deviáns, antiszociális magatartású gyerekek. A gyerekek életkörülményeire jellemzö, hogy az otthonok túlzsúfoltakká váltak, néhol tömegszállásra emlékeztetnek. (Hanák, 1978) Ezen túlmenően a gyermekek nevelőotthonokban való elhelyezése során nem vették figyelembe a gyerekek igényeit sem. A szükségletekre való reagálás sokkal differenciáltabb intézményrend- 
szer kialakítását tette volna szükségessé. Ehelyett elsősorban az életkor szerinti elhelyezés volt a jellemzö.

Magyarországon a 80-as évektől vált egyre fontosabb céllá a széles korhatárú, koedukált, differenciált nevelőotthoni hálózat kialakítása. A nevelési programjukat 1985-ben adták ki, amely a nevelőotthonok müködésére vonatkozó módszertani ajánlásokat tartalmaz. A döntés szerint a nevelöotthon az állami gondoskodásnak és a köznevelés intézményrendszerének is szerves része. Müködésére jelentősen hatott az a tény, hogy a közoktatáshoz sorolták ezeket az intézményeket.

A nevelőotthonok feladatai a következőkben foglalhatók össze. Elöször is otthont nyújt az állami gondoskodásra szoruló gyermekeknek. Biztosítja a gyerekek testi, értelmi, erkölcsi és szellemi fejlődését, valamint segíti a gyermek és családja közötti kapcsolat rendezését. Gondoskodik a nevelőotthonban élő fiatalok pályaválasztásának előkészítéséről, az önálló életre való felkészítésröl, és az utógondozásról. A nevelőotthonok oktatási fokozat, korcsoport, nem, létszám, földrajzi elhelyezkedés szerint csoportosíthatók. 1985-ben nem és oktatási fokozat szerint a következő otthonok müködtek. Volt óvodai, koedukált alsó tagozatos, koedukált felsős tagozatos, koedukált általános iskolai, fiú általános iskolai, lány általános iskolai csoport, lány alsó tagozatos, ifjúsági lány, ifjúsági fiú, koedukált ifjúsági és speciális. (Domszky, 1985)

A dolgozatban a történeti áttekintés során is említettük, hogy az otthonok többsége 100 férőhelyes, és a csoportba jutó gyerekek száma az otthonok egyharmad részében 26-30 fö. A fenti mutatók alapján szükségessé vált az otthonok széles korhatárú, koedukált otthonná való átalakítása. Az 1997. évi gyermekvédelmi törvény másik nagy vívmánya az, hogy a több száz fős nevelőotthonok, gyermekvárosok átalakítását irányozza elő. A gyermekotthon legalább 12, de legfeljebb 40 gyermekotthont nyújtó ellátását biztosítja. Az otthont nyújtó ellátások tekintetében a Gyermekvédelmi törvény egyértelmủvé teszi, hogy a gyerek gondozásán, nevelésén túl a családdal való kapcsolattartás és a visszakerülés előkészítése, segítése is feladata az otthont nyújtó intézménynek. Valamint speciális ellátás illeti meg azokat a gyerekeket, akiknek valamilyen okból erre szükségük van, és ennek igazodnia kell a gyerek korához, állapotához. Az utógondozás is feladata az ellátóknak, elsősorban lakhatás és ellátás biztosításával, de jó esetben éppen a rendszerből való mielőbbi kikerülés előkészítésével és megvalósíthatóságával. A törvény egyértelmủen jelöli meg azokat a szakmai prioritásokat, amelyeket a gyerek elhelyezése szempontjából előnyösnek tekint.

A gyermekotthonok átalakítása elsősorban tehát azt a célt szolgálja, hogy a gyerekek életkorának, élethelyzetének, fejlődési szükségleteinek megfelelő, minél inkább családszerủ ellátást biztosítson, amely egyben lehetőséget ad a speciális szükségletek kielégítésére, a lemaradások pótlására, a praktikus készségek és társas helyzetek elsajátítására, az érzelmi biztonság, állandóság megtapasztalására. A kérdés az, hogy kinek a számára és mely élethelyzetben jó és szükséges a gyer- 
mekotthon, és milyen feltételeknek kell megfelelnie ehhez.”(Domszky, 1999)

A gyermekotthon tehát ellátást biztosít az ideiglenes hatállyal elhelyezett, az átmeneti és tartós nevelésbe vett gyermek számára. Utógondozói ellátást biztosít a fiatal felnőtt számára és szükség esetén külső férőhelyet működtet. Munkáját a szakmai programja alapján végzi.

A gyermekek ellátását az általa elkészített egyéni gondozási nevelési terv alapján végzi, biztosítja továbbá a gyámhivatal határozata alapján a gyámi feladatok ellátását. Segíti a gyermeket iskolai tanulmányaiban, szakképzettség megszerzésében, tanít az előtakarékosságra, az önálló életre.

13. táblázat. Általános iskolát végzettek továbbtanulási arányának megoszlása 1990-2002

\begin{tabular}{|c|c|c|c|c|c|c|}
\hline \multirow{2}{*}{ Év } & \multicolumn{2}{|c|}{ Gimnáziumban } & \multicolumn{2}{c|}{ Szakközépiskolában } & \multicolumn{2}{c|}{$\begin{array}{c}\text { Szakmunkásképzőben, } \\
\text { szakiskolában }\end{array}$} \\
\cline { 2 - 7 } & $\begin{array}{c}\text { Saját } \\
\text { családban } \\
\text { élő́k }\end{array}$ & $\begin{array}{c}\text { Gyermek- } \\
\text { védelemben } \\
\text { részesülök }\end{array}$ & $\begin{array}{c}\text { Saját } \\
\text { családban } \\
\text { élők }\end{array}$ & $\begin{array}{c}\text { Gyermek- } \\
\text { védelemben } \\
\text { részesülók }\end{array}$ & $\begin{array}{c}\text { Saját } \\
\text { családban } \\
\text { élők }\end{array}$ & $\begin{array}{c}\text { Gyermek- } \\
\text { védelemben } \\
\text { részesüloók }\end{array}$ \\
\hline $\mathbf{1 9 9 5}$ & 27,1 & 3,0 & 33,7 & 6,0 & 38,5 & 80,0 \\
\hline $\mathbf{2 0 0 0}$ & 32,1 & 6,4 & 39,0 & 18,0 & 25,3 & 65,1 \\
\hline $\mathbf{2 0 0 2}$ & - & 7,4 & - & 14,5 & - & 67,4 \\
\hline
\end{tabular}

Forrás: Tóth Judit Nikoletta (Szerk.)(2004): A gyermekvédelmi szakellátás helyzete a XX. században KSH, Budapest, 26.o.

Az iskolai tanulmányokra vonatkozóan megállapíthatjuk, hogy a gyermekvédelemben részesülök gimnáziumban való továbbtanulása 1995 és 2000 közötti időszakban 3-ról $6 \%$-ra nőtt. (13. táblázat) Ellentmondásos ez a helyzet, mert jelentősen elmarad a saját családban élő gyerekek gimnáziumi továbbtanulása mögött, ami az említett időszakban 27,1\% és 32,1 \%-os. A szakközépiskolákban továbbtanuló gyerekek száma is többszörösére növekedett 1995-ben 6\%-uk, 2002-ben már $14,5 \%$-uk tanult tovább ebben az intézménytípusban. A saját családban élők körében ilyen mértékü növekedést nem mutatnak az adatok. A gyermekvédelemben részesülő gyerekek legnagyobb arányban szakmunkásképzőben, szakiskolában tanultak tovább. 1995-ben 80\%-uk, 2002-ben 67,4\%-uk járt ebbe az iskolatípusba. A szakiskolában való továbbtanulás csökkenése mögött valószínűleg az áll, hogy a szakiskolák iránti érdeklődés csökkent az elmúlt években. Ugyanakkor az intézményekben élő gyerekek szívesen választják a szakközépiskolai továbbtanulást, aminek az aránya növekedett. Az Ifjúság 2004 kutatás adatai szerint a szakmunkásképzés erőteljes propagálásának hatására megállt a szakmunkásképzésben tanulók aránycsökkenése. Míg 2000-ben az iskolarendszerben tanulók 11 \%-a tanult szakmunkásképzőben, szakiskolában, addig 2004-ben $13 \%$. Az adatok szerint kis 
mértékben nőtt a szakiskolákban tanulók aránya, azonban trendváltásra még nem került sor. (Bauer, Szabó, 2005)

Összességében megállapítható, hogy a gyermekvédelemben részesülők közül többen tanulnak tovább, mint a korábbi években. A gyerekek továbbtanulását segítette a középfokú oktatás expanziója mellett a gyermekvédelmi intézmények azon törekvése, hogy legalább egy szakképzettséget szerezzenek a gyerekek, ezzel is támogatva őket az önálló életre való felkészülésben.

Az adatok alapján megállapítható, hogy a gyermekotthonok igyekeznek a gyerekeket felkészíteni a továbbtanulásra, ami megmutatkozik abban is, hogy megnőtt az érettségit adó képzésben való részvételi arány.

14. táblázat. 2004/2005-ös tanévben az általános iskolát befejezettek továbbtanulása

\begin{tabular}{|l|c|c|c|}
\hline \multirow{2}{*}{ Iskolatípus } & $\begin{array}{c}\text { Gyermek- } \\
\text { otthon }\end{array}$ & $\begin{array}{c}\text { Nevelőszülői } \\
\text { hálózat }\end{array}$ & Együtt \\
\cline { 2 - 4 } & \multicolumn{3}{|c|}{ A tanulók közül } \\
\hline Gimnáziumban tanul & 41 & 87 & 128 \\
\hline Szakközépiskolában tanul & 109 & 163 & 272 \\
\hline Szakiskolában tanul & 644 & 359 & 1003 \\
\hline $\begin{array}{l}\text { Iskolarendszeren kívüli tanfolyami } \\
\text { szakoktatásban vesz részt }\end{array}$ & 14 & 7 & 21 \\
\hline Nem tanul & 111 & 12 & 123 \\
\hline Összesen: & 919 & 628 & 1547 \\
\hline
\end{tabular}

Forrás: Tájékoztató a család, gyermek- és ifjúságvédelem helyzetéröl SZMM Gyermek- és Ifjúságvédelmi föosztály, 2006. 58. o.

A gyermekvédelmi gondoskodás alatt állók továbbtanulására az is más-más hatással van, hogy nevelőszülőnél vagy gyermekotthonban élnek-e. Az általános iskolát befejezett tanulók továbbtanulását áttekintve jól látszik, hogy mind a gyermekotthonban, mind a nevelőszülőnél élő gyerekek közül a többség valamilyen szakma megszerzését tekinti célnak. (14. táblázat) A nevelőszülőnél elhelyezettek 57,1 \%-a, a gyermekotthonban élők 70 \%-a szakiskolában, szakmunkásképzőben tanult tovább. A továbbtanulás szempontjából lényeges, hogy amíg a nevelőszülőnél élők 39,8\%-a, addig a gyermekotthonban elhelyezettek 16,3\%-a érettségit adó intézményben folytatja tanulmányait. A középfokú képzésre jellemzö, hogy amíg a nevelőszülőknél élők 13,8 \%-a, addig a gyermekotthonban élőknek csak a 4,5 \%- a tanul gimnáziumban. A gyermekotthonban élők inkább választják a szakközépiskolai továbbtanulást, ami a korábbi munkavállalásra készít fel. Az adatok 
alapján az is látszik, hogy lényeges különbség van a nem tanulók aránya esetében a nevelőszülőknél és a gyermekotthonokban élők között. A gyermekotthonban $12 \%$ nem tanul, a nevelőszülőnél elhelyezettek között csak 1,9\%-os ez az arány. A továbbtanulásra vonatkozó adatok azt mutatják, hogy a nevelőszülőnél élők eredményesebbek a továbbtanulásban. Tehát az adatok alapján megállapítható, hogy a nevelőszülőknél való elhelyezés előnyös a gyerekek számára, a családban élő gyerekek továbbtanulási mutatói jobbak, mint az intézményben élő gyerekeké. Az eredményesebb iskolai mutatókhoz azonban az is hozzájárulhat, hogy a hagyományos nevelőszülőknek lehetőségük van választani a gyerekek közül.

15. táblázat. Gyermekotthoni gyermekcsoportok száma 2005.

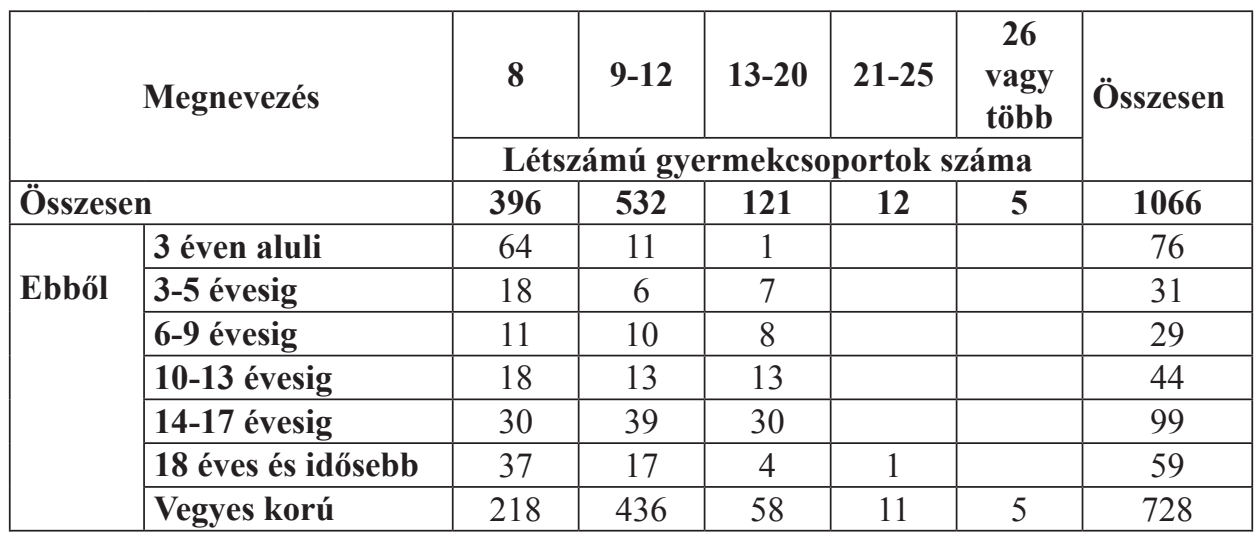

Forrás: Tájékoztató a család, gyermek- és ifjúságvédelem helyzetéröl SZMM Gyermek- és ifjúságvédelmi Föosztály, 2006. 68. o.

A gyermekek életkörülményeiben bekövetkezett változásokat jól szemléltetik a 15. táblázat adatai. Megállapítható, hogy 2005-ben összesen 1066 gyermekcsoport müködött a gyermekotthonokban. A létszám kialakításában érezhető a szakemberek azon törekvése, hogy minél kevesebb gyerek legyen egy csoportban, mert így átláthatóbbak a csoportdinamikai folyamatok, jobb minőségü kapcsolat alakulhat ki a csoport tagjai és a nevelök között. Ezek a tényezők pedig a gyerekek életkörülményeit pozitívan befolyásolják. Az adatokból az látszik, hogy a 8 fös és a 9-12 fös csoportok kialakítása a jellemző az otthonokban. A legtöbb a 9-12 fővel müködő csoportból van, összesen 532. Még mindig jelentős azonban a 13-20 fövel müködök száma is, mert nincs lehetőség a kisebb csoport múködtetésére. Ez viszont nehezebbé teszi az egyéni bánásmód alkalmazását. A táblázatból az is kiderül, hogy a gyerekek életkorát tekintve a nagyobb létszámú csoportok kialakítása 14 éves kortól jellemző. Ez azért jelent problémát, mert a serdülőkorú gyerekek esetében különösen szükség lenne a szemé- 
lyesebb kapcsolatok kialakítására. Az életkor vonatkozásában a vegyes életkorú csoportból müködik több, összesen 728.

\section{Lakásotthon}

Lakásotthonok 1997 előtt csak kis számban, kísérleti jelleggel müködtek Magyarországon. Olyan gyermekotthonok ezek, amelyek legfeljebb 12 gyermek ellátását biztosítják önálló lakásban vagy családi házban, családias körülmények között. A nagy otthonok kiváltása több helyen már a törvény életbelépését megelőzően elkezdődött, vagyis a gyakorlatban dolgozók egy része megelőzte a törvényt a változtatásokban.

Az átalakítások során felmerülő problémák három csoportra bonthatók. Az első csoportot a tárgyi feltételek megteremtéséhez kapcsolódó nehézségek jelentik. Nem minden épület adható el, vagy hasznosítható a korábbi gyermekotthonok közül.

Probléma az is, hogy a lakosság egy része tiltakozott a megvásárolt családi házakba költöző gyerekek telepítése ellen. A kisebb otthon nem jelent automatikusan jobb ellátást. Nem tudták és nem is mindig akarták szempontként figyelembe venni, hogy a gyerekek iskoláztatása, munkahelye, családi kapcsolatai szempontjából melyek az alkalmas települések. Ugyancsak nem tudták vagy nem akarták tekintetbe venni a rendelkezésre álló egyéb segítő szolgálatok és szakemberek elérhetőségét. A felmerülő nehézségek második nagy csoportját a személyi feltételek jelentik. A dolgozók közül sokan a változás következtében munkanélkülivé válhatnak. Ez elsősorban a kieső helyeken, kistelepülésen müködő otthonokban jellemző. Nem mindenki akar és nem mindenki alkalmas a lakásotthoni vagy más gyermekvédelmi munkakörökben dolgozni a korábban otthonokban dolgozók közül. A lakásotthonok elhelyezkedése miatt kérdéses az irányítás optimális formája. A harmadik csoportba a gyerekekkel kapcsolatos nehézségek sorolhatók. A gyerekek számára probléma, hogy az átalakítás nagy változás és gyakran megrázkódtatás, amire nem készítették fel öket.(Herczog, 2001)

A gyermekotthonok többféle funkciót töltenek be. Ezeket elsősorban akkor tudják teljesíteni, ha léteznek azok a társintézmények (például családsegítő központ, gyermekjóléti szolgálat, nevelési tanácsadó, gyermek-ideggondozó stb.), amelyek szolgáltatásaikkal kiegészítik a müködését. Ezek hiányában a gyermekotthonokat az a veszély fenyegeti, hogy vállalniuk kell a hiányzó funkciókat. Ezáltal könnyen totális intézménnyé válhatnak. (Domszky, 2003)

A fentiek alapján megállapítható, hogy az intézmények átalakítása során figyelembe kellett venni a személyi-tárgyi feltételeket, az intézmények integrált elhelyezésének lehetőségeit. Az integrált elhelyezés részben a kis létszámú otthonok létrehozásával, részben a lakókörnyezetbe való elhelyezéssel valósítható meg. A lakásotthonok integrált megszervezésének az is fontos eleme, hogy a gyerekek 
számára szükséges pedagógiai, szociális szolgáltatásokat a lakásotthon környezetében található intézmények biztosítják, ezzel is segítve a benne élők szocializációját. A lakásotthonok létrejöttével az otthonok funkciója is változott. Már nem egy minden szolgáltatást egy helyen nyújtó otthonról beszélhetünk, hanem az ellátandó feladatokat a különböző intézmények között megosztó otthonról. Ezzel a lakásotthonok hozzájárultak a gyerekek életkörülményeinek a javításához.

16. táblázat. Féröhelyek és gyermekek száma az ellátás típusa szerint 2005

\begin{tabular}{|c|c|c|c|c|c|c|c|c|}
\hline \multirow[t]{2}{*}{ Megnevezés } & \multirow[t]{2}{*}{$\begin{array}{l}\text { Engedélye- } \\
\text { zett férőhe- } \\
\text { lyek száma }\end{array}$} & $\begin{array}{l}\text { Ideig- } \\
\text { lenes } \\
\text { hatállyal } \\
\text { elhelye- } \\
\text { zett }\end{array}$ & $\begin{array}{l}\text { Átme- } \\
\text { neti } \\
\text { nevelt }\end{array}$ & $\begin{array}{l}\text { Tar- } \\
\text { tós } \\
\text { ne- } \\
\text { velt }\end{array}$ & $\begin{array}{l}\text { Össze- } \\
\text { sen }\end{array}$ & $\begin{array}{l}\text { Utó- } \\
\text { gon- } \\
\text { dozói } \\
\text { ellátás- } \\
\text { ban ré- } \\
\text { szesülő́ } \\
\end{array}$ & $\begin{array}{l}\text { Átme- } \\
\text { neti } \\
\text { gondo- } \\
\text { zott }\end{array}$ & \multirow[t]{2}{*}{$\begin{array}{l}\text { Mind } \\
\text { össze- } \\
\text { sen }\end{array}$} \\
\hline & & \multicolumn{6}{|c|}{ gyermekek száma } & \\
\hline \multicolumn{9}{|c|}{ Gyermekotthon } \\
\hline $\begin{array}{l}\text { Gyermekott- } \\
\text { hon }\end{array}$ & 3651 & 376 & 2429 & 107 & 2912 & 392 & 29 & 3333 \\
\hline Lakásotthon & 4608 & 105 & 3019 & 291 & 3415 & 832 & 2 & 4249 \\
\hline $\begin{array}{l}\text { Speciális } \\
\text { gyermekott- } \\
\text { hon }\end{array}$ & 384 & 2 & 270 & 26 & 298 & 19 & & 317 \\
\hline $\begin{array}{l}\text { AID és gyer- } \\
\text { mekotthon }\end{array}$ & 1032 & 16 & 603 & 83 & 704 & 177 & & 879 \\
\hline $\begin{array}{l}\text { Utógondozó } \\
\text { otthon }\end{array}$ & 571 & & 2 & & 2 & 449 & & 451 \\
\hline $\begin{array}{l}\text { Különleges } \\
\text { gyermekott- } \\
\text { hon }\end{array}$ & 607 & 58 & 334 & 67 & 459 & 62 & & 521 \\
\hline
\end{tabular}

Forrás: Tájékoztató a család, gyermek- és ifjúságvédelem helyzetéröl SZMM Gyermek- és ifjúságvédelmi föosztály 2006. 53.o.

A gyerekek elhelyezésének lehetőségeit illusztrálja a 16. táblázat. Az adatok alapján egyértelmü, hogy 2005-ben a legtöbb férőhelyet - összesen 4608-at- a lakásotthonok biztosították a rászoruló gyerekek számára. Ennek megfelelően a legtöbb gyerek (4249 fö) ebben az intézménytípusban került elhelyezésre. A lakásotthonokat a gyermekotthonok 3651 féröhellyel szorosan követik. A legkevesebb féröhellyel a speciális gyermekotthonok rendelkeznek, összesen 384 hely áll rendelkezésre. Ez azért van így, mert új speciális intézmények létrehozására csak korlátozottan van mód a müködtetés költségei miatt. Az elhelyezett gyerekek között -jogi státuszukat tekintve- legtöbben az átmeneti neveltek vannak. 
A gyermekvédelmi intézményekben gyakran előfordul a szökés. A szökések száma utalhat arra, hogy a gyerekek mennyire elégedettek az életkörülményeikkel. A szökések szempontjából különbségek vannak a gyermekotthonok között.

17. táblázat. Szökések, szökési esetek száma gondozási hely szerint 2005

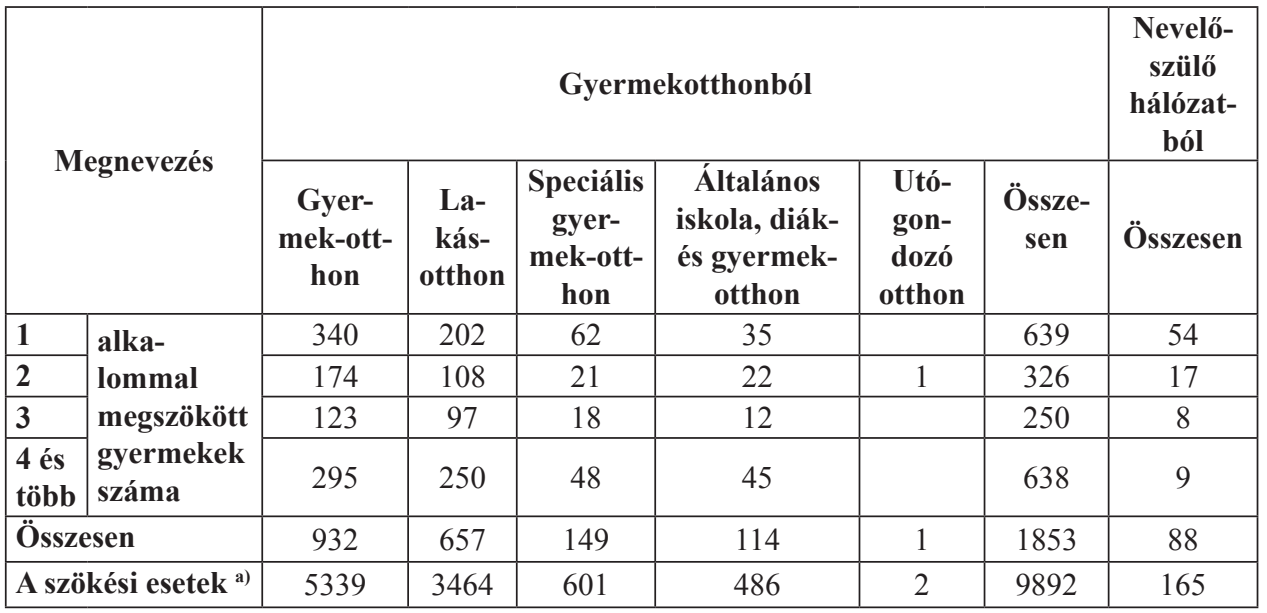

a) A szökött gyermekek száma és a szökési alkalmak számának szorzata.

Forrás: Tájékoztató a család, gyermek- és ifjúságvédelem helyzetéröl SZMM Gyermek- és ifjúságvédelmi föosztály, 2006. 61.o.

A legtöbb (5339 eset) szökés a gyermekotthonból történt. Jóval kevesebbet (3464 eset) regisztráltak a lakásotthonokban 2005-ben. (17. táblázat) Az összes szökés több mint fele (54\%) gyermekotthonból történt. A lakásotthonok kedvezőbb adatai részben arra vezethetők vissza, hogy az ott elhelyezett gyerekek száma maximum 12 fö lehet, így több személyes kapcsolatra van lehetőség az intézmény dolgozói és a gyerekek között. Jobban érzik magukat a gyerekek, jobb kapcsolatuk van egymással, a nevelőikkel. A nevelőszülői hálózatból való szökés lényegesen kevesebb, mint a gyermekotthoni. A szökések gyakoriságát tekintve - mind a gyermekotthonban, mind a lakásotthonban- a legmagasabb az 1 alkalommal és a 4 vagy több alkalommal szököttek száma. A gyermekotthonból és a lakásotthonból való összes szökés 34, $4 \%$-a 4 vagy több alkalommal történt. Az adatok alapján megállapítható, hogy a gyerekek életkörülményei befolyásolják a szökési hajlandóságot. A kisebb létszámú, kedvezőbb életfeltételeket biztosító otthonokban kevésbé fordul elő.

\section{Utógondozó otthon}

1997 előtt nem müködtek utógondozó otthonok, az állami gondoskodásból kikerült fiatalokat pártfogók segítették a társadalmi beilleszkedésben. Társadalmi és hiva- 
tásos pártfogók látták el ezt a feladatot. A nevelőotthoni nevelés továbbfejlesztett programjában (1976) már foglalkoztak az utógondozás kérdésével. Ez speciális pedagógiai tevékenység és prevenció, a nevelőotthon további gondoskodása azokról a fiatalokról, akik az otthonból más intézménybe kerültek. A másik eset, amikor a nagykorúságot elérve, az állami gondozás megszünésével a nevelőotthont elhagyva további életüket önállóan kénytelenek megszervezni. (A nevelőotthoni nevelés továbbfejlesztett programja, 1976)

A fentiekben leírtak jól illusztrálják, hogy az utógondozást nem csak a fiatal intézményből való kikerülése, hanem egyik intézményből a másik intézménybe való átkerülése során is fontosnak tartották, tekintve, hogy az otthonok életkor szerint szerveződtek. 1997 előtt az utógondozás színterei tehát a nevelőotthon, a középiskolai kollégium, az ifjúsági otthon, az albérlet, a családi otthon, a munkásszálló voltak.

A gyermekvédelmi törvény vezette be az utógondozást. Az elmúlt évtizedek tapasztalata az volt, hogy a fiatalok, kikerülve az intézményes ellátásból, nem tudtak beilleszkedni a társadalomba. Ennek a jelenségnek több oka volt. Az egyik, hogy az iskolázottságuk nem volt megfelelő, vagy nem tudták a nagykorúság eléréséig befejezni tanulmányaikat. Munkába állásuk az alacsony képzettség miatt ütközött nehézségbe. Ezen a helyzeten próbált a gyermekvédelem segíteni az utógondozó otthonok létrehozásával. Ha a gyermekotthon kizárólag a felnőttek teljes körü utógondozói ellátását biztosítja, a gyermekotthon utógondozó otthonként müködik.

Az utógondozás és az utógondozói ellátás tercier prevencióként a fiatal felnőtt sikeres társadalmi beilleszkedését szolgálhatja, hogy ne szoruljon felnőtt életében ellátásra. Az utógondozás és az utógondozói ellátás, és ezen keresztül a társadalmi beilleszkedés sikerét a következő tényezők befolyásolják. A fiatal felnőttek személyisége, meglévő belső erőforrásaik, a családi hátterük, kapcsolattartásuk szüleikkel, a gondoskodásban eltöltött idő hossza, az ezen időszak alatt szerzett esetleges mentális sérülések mélysége. A társadalmi beilleszkedést befolyásolja továbbá a gondoskodás ideje alatt kiépített kapcsolataik, szocializációjuk, az iskolázottságuk. (Szikulai, 2004)

A törvény szabályozza az utógondozói ellátás feltételeit is. Az ellátást a gyámhivatal a fiatal felnőtt kérelmére rendeli el, ha a gyermek illetve a fiatal felnőtt átmeneti vagy tartós nevelésbe vétele nagykorúvá válásával szünt meg, és létfenntartását önállóan biztosítani nem tudja, vagy nappali oktatás munkarendje szerinti, vagy felsőfokú iskola nappali tagozatán tanulmányokat folytat, vagy szociális intézetbe felvételét várja. Az utógondozói ellátást a fiatal felnőtt 24 éves koráig kérheti. Az utógondozást legalább egy évre rendeli el a gyámhivatal. Az ellátás indokául szolgáló három -törvényben elöírt- lehetőség közül 2002- ben a gondozottak 58 \%-a hivatkozott nappali tagozatos tanulmányaira, az 1998. évi (a törvény hatályba lépésének utáni év) $55 \%$-os megoszláshoz képest. $41 \%$-uk kérte létfenntartási nehézségeire hivatkozva az utógondozói ellátás elrendelését. 1998-ban ez az arány 
40 \%-os volt. A harmadik ok, a valamilyen otthonba felvételüket kérök aránya, föleg a fogyatékosokat érinti, arányuk az utóbbi években 3-7 \% körül mozog. (Tóth, 2004)

Az utógondozás gyermekotthonban, nevelöszülőnél, utógondozó otthonban vagy külső férőhelyen valósulhat meg.

A fenti adatokból látható, hogy a fiatalok jelentős hányada tanulmányokat folytat, ami indokolttá teszi hosszabb ideig tartó ellátásukat. Az Ifjúság 2004 kutatás által bemutatott tendenciák, mint például a szakképzettség megszerzésének kitolódása, a gyermekvédelmi intézményekben élő fiatalokra is jellemző. Így szükségessé vált a fiatalokról való gondoskodás különböző formákban való megszervezése, az utógondozás korhatárának 25. életévre való felemelése. A következő években jelentős feladat lesz a szakemberek számára az utógondozói ellátás megszervezése, tekintve, hogy egyre többen maradnak a rendszerben a nagykorúvá válás után is.

18. táblázat. Utógondozói ellátásban részesülö fiatalok száma tartózkodási hely szerint 2005

\begin{tabular}{|l|c|c|c|c|}
\hline \multicolumn{1}{|c|}{ Megnevezés } & Összesen & $\begin{array}{c}\text { Létfenntartá- } \\
\text { sát önállóan } \\
\text { biztosítani nem } \\
\text { tudja }\end{array}$ & $\begin{array}{c}\text { Bentlakásos } \\
\text { szociális } \\
\text { intézménybe } \\
\text { felvételre vár }\end{array}$ & $\begin{array}{c}\text { Nappali tagoza- } \\
\text { ton tovább tanul }\end{array}$ \\
\hline \multicolumn{5}{|c|}{ Gyermekotthon } \\
\hline Gyermekotthon & 454 & 121 & 24 & 309 \\
\hline Lakásotthon & 836 & 200 & 49 & 587 \\
\hline Speciális gyermekotthon & 19 & 10 & 1 & 8 \\
\hline $\begin{array}{l}\text { Általános iskola, diák- } \\
\text { otthon és gyermekotthon }\end{array}$ & 186 & 38 & 13 & 135 \\
\hline Utógondozó otthon & 462 & 193 & 1 & 268 \\
\hline Egyéb & 232 & 124 & 2 & 106 \\
\hline Összesen & 2189 & 686 & 90 & 1413 \\
\hline & \multicolumn{5}{|c|}{ Nevelőszülői hálózat } & & 245 \\
\hline Hivatásos nevelőszülő & 332 & 85 & 2 & 1019 \\
\hline $\begin{array}{l}\text { Hagyományos nevelö- } \\
\text { szülő }\end{array}$ & 1598 & 563 & 16 & 1264 \\
\hline Összesen & 1930 & 645 & 18 & \\
\hline
\end{tabular}

Forrás: Tájékoztató a család, gyermek- és ifjúságvédelem helyzetéröl, SZMM Gyermek- és ifjúságvédelmi Föosztály, 2006. 62. o.

Az utógondozói ellátást többféle intézményben, illetve a nevelőszülői hálózatban vették igénybe, 2005-ben összesen 4119-en. (18. táblázat). A legtöbb utógondo- 
zói ellátott a lakásotthonokban (836 fö) és a hagyományos nevelőszülőknél (1930 fó) élt. Az utógondozó otthonokban 2005-ben 462-en kerültek elhelyezésre, ez a lakásotthonokhoz képest kis létszám, ami az utógondozó otthonok alacsony számának tudható be. Az adatok rávilágítanak az ellátás igénybevételének okára is. A legtöbben (2677 fö) a nappali tagozaton való továbbtanulás miatt igényelték az ellátást. Ezt követi a létfenntartási nehézségek köre, összesen 1331 fö esetében. A szociális intézménybe való elhelyezésre várók száma a legalacsonyabb mindössze 108 fö.

A '80-as, '90-es évek kutatásai is igazolták, hogy az állami gondozásból kikerülő fiatalok nagykorúvá válásuk után nehezen tudnak beilleszkedni a társadalomba. (Hanák, 1985, Strauszné, 1990). Az utógondozással kapcsolatos újabb kutatások is arra hívják fel a figyelmet, hogy a fiatalok társadalmi integrációja a gyermekvédelmi intézményrendszer átalakítását követően sem valósul meg maradéktalanul. (Szikulai 2004, Rácz, 2006)

A fiatalok társadalmi beilleszkedési nehézsége több okra vezethető vissza. Ezek között megemlíthető a családdal való kapcsolattartás gyengesége, a hiányos szocializáció, a fiatal felnőttek iskolázatlansága, a munkába állás és a lakáshoz jutás nehézségei, a pénzkezelés hibái. További problémát jelent az utógondozó szakembergárda felkészületlensége is. (Szikulai, 2004)

\subsection{Nevelőszülői elhelyezés}

A nevelőszülői elhelyezés mindig része volt a gyermekvédelemnek, igaz, hangsúlyeltolódások voltak az intézményi elhelyezés javára, ahogy ezt a gyermekvédelem 1945 utáni történeti áttekintésében is láttuk. A 80-as évektől fogalmazódott meg a nevelőotthoni hálózat középtávú fejlesztési tervében, hogy a nevelöszülői hálózat fejlesztése indokolt. 1984-ben az állami gondozott gyermekek 25\%-a, 7747 fö nevelkedett nevelőszülőknél, ami a fejlettebb szociálpolitikával rendelkező országok mutatóitól nagyságrendekkel elmaradt.

Az 1997. évi XXXI. törvény bevezetése után a nevelőszülői elhelyezés lesz preferált. A '90-es évek második feléig a nevelőszülők száma csökkentő tendenciát mutat a KSH (2004) adatai szerint 1990-ben 5373 nevelöszülő müködött, 1997ben kevesebben, 4809-en, míg 2002-ben 5020-an láttak el ilyen jellegü feladatot. Az elmúlt években, 2002 és 2005 között kis mértékben, de nőtt a feladatra vállalkozók száma. A 2002-es 5020 föről a 2005-ös, 5323 före. 
19. táblázat. Nevelöszülők száma 2005

\begin{tabular}{|c|c|c|c|c|}
\hline \multicolumn{2}{|c|}{ Nevelőszülők száma, akiknél } & $\begin{array}{l}\text { Hivatásos nevelö- } \\
\text { szülö }\end{array}$ & $\begin{array}{l}\text { Hagyományos } \\
\text { nevelöszüllö }\end{array}$ & Összesen \\
\hline $\mathbf{0}$ & \multirow{7}{*}{$\begin{array}{l}\text { Fó gyermekvédelmi } \\
\text { gondoskodás alatt } \\
\text { álló gyermek van } \\
\text { elhelyezve }\end{array}$} & 2 & 474 & 476 \\
\hline 1 & & 16 & 1867 & 1883 \\
\hline 2 & & 31 & 1189 & 1220 \\
\hline 3 & & 40 & 783 & 823 \\
\hline 4 & & 57 & 384 & 441 \\
\hline 5 & & 84 & 167 & 251 \\
\hline $\begin{array}{c}6 \text { vagy } \\
\text { több }\end{array}$ & & 17 & 59 & 229 \\
\hline \multicolumn{2}{|c|}{ Összesen } & 400 & 4923 & 5323 \\
\hline
\end{tabular}

Forrás: Tájékoztató a család, gyermek- és ifjúságvédelem helyzetéröl SZMM Gyermek- és Ifjúságvédelmi föosztály, 2006. 59. o.

2005-ben 400 hivatásos és 4923 hagyományos nevelöszülő múködött Magyarországon. (19. táblázat). Jellemző, hogy a nevelőszülők leginkább 1-2-3 gyermek nevelésére vállalkoztak. Kevesebben vállalták 5 vagy annál több gyerek nevelését, 2005-ben 480 nevelőszülö. A nevelőszülökre is kiterjedő országos vizsgálat megállapította, hogy a nevelőszülői hálózatok nem fejleszthetők korlátlanul a feladatokra alkalmas nevelőszülők hiánya miatt. 1999 és 2002 között 4789 föről 5020 före emelkedett a nevelőszülők száma a kutatás adatai szerint. A nevelőszülők számának lassú növekedésében a kevés jelentkező, valamint a nevelöszülők elöregedése játszik szerepet. A vizsgálat szerint sokan egzisztenciális gondjaik megoldására, más lehetőség hiányában jelentkeznek nevelőszülőnek. (Berényi és mtsai, 2004)

A nevelőszülővé válásnak számos feltétele van. Nevelőszülő az lehet, aki huszonnegyedik életévét betöltötte, cselekvőképes, büntetlen elöéletü, a gondozásba helyezett gyereknél legalább tizennyolc, legfeljebb negyvenöt évvel idősebb. A személyes alkalmasság, a megfelelő tárgyi, környezeti feltételek mellett a nevelőszülőknek képzésben kell részt venniük. Tehát az alkalmasság önmagában nem elégséges, hanem szükséges a feladatra való felkészítés, majd azt követően a folyamatos továbbképzés. Ez igaz a már gyermeket gondozókra is. Nekik is továbbképzésen kell részt venniük, de ha ez nem történik meg érdemi szankciók alkalmazására nincs lehetőség.

A nevelőszülői elhelyezés történhet nevelőszülőnél, hivatásos nevelöszülőnél, speciális hivatásos nevelőszülőnél. A nevelőszülők alkalmazása különböző formákban lehetséges. A hagyományos nevelöszülő megállapodás, a hivatásos nevelőszülő munkaszerződés alapján végzi a tevékenységét. A gyermekek számát 
minden esetben a törvény szabályozza. A speciális hivatásos nevelőszülő az a hivatásos nevelőszülő, aki a képesítési előírásoknak megfelel, és alkalmas a nála elhelyezett súlyos pszichés vagy disszociális tüneteket mutató, illetve pszichoaktív szerekkel küzdő, speciális ellátást igénylő gyermek kiegyensúlyozott nevelésének biztosítására.

Gyakran felmerülő probléma, hogy a hagyományos nevelőszülők szeretnék megválogatni gondozottjaikat. A tapasztalatok szerint a problémás, idősebb, kamaszkorú gyermekek gondozását nem vállalják, ragaszkodnak a csecsemö-, óvodáskorú gyermekekhez. A hivatásos nevelőszülőknek több gyermeket kell gondozniuk, és nem válogathatnak a gyerekek között. (Berényi és mtsai, 2004)

A nevelőszülők nem elszigetelten, hanem nevelőszülői hálózatban müködnek. A nevelőszülői hálózat legalább 5 nevelőszülőből áll. Munkájukat a nevelőszülői tanácsadó segíti. 2006-os statisztikai adatok szerint a családjából kiemelt gyermekvédelmi gondoskodásban élő gyermekek $53 \%$-a nevelőszülőnél nevelkedik. A nevelöszülői ellátás mellett szóló érvek közé tartozik a gazdaságossági szempont is. Ez az ellátás költséghatékonyabb, mint a gyermekotthoni/lakásotthoni elhelyezés. Tehát megállapítható, hogy megvalósulni látszik a gyermekvédelmi törvény azon törekvése, hogy minél több gyerek éljen családias körülmények között, vagyis nevelőszülőknél kerüljön elhelyezésre. A következő években - a törvény szellemének megfelelően- valószínúleg tovább fog nőni a nevelőszülőknél elhelyezett gyerekek száma. Ehhez azonban szükséges a nevelőszülői feladatra való felkészítés, a folyamatos segítségnyújtás, képzések, tréningek szervezése a feladat jó minőségü ellátása érdekében.

\subsection{Javító-nevelő intézet}

A javító-nevelő intézetek a múlt században is müködtek. Az 1878. évi V. törvénycikk, a Csemegi Kódex tette lehetővé, hogy a fiatalkorúakat külön kategóriaként kezeljék a büntetőjogban. Ennek hatására 1854-ben Aszódon jött létre az ország első javító-nevelő intézete fiatalkorú fiúk számmára, majd 1890-ben Rákospalotán lányok számára. Jelentős változást hozott az 1908-as Büntetőnovella, ami a fiatalkorúak által elkövetett büncselekmények büntetése helyett a nevelést helyezte előtérbe. (Hatvani- Papházi, 2004)

A gyermekvédelem speciális ellátórendszeréhez tartoznak a javító-nevelő intézetek. Ezekben az intézetekben a bíróság által javítóintézeti nevelésre utalt, illetve az előzetes letartóztatásba helyezett bünelkövető fiatalkorúak élnek. Ezeknek a fiatalkorúaknak, mivel bünelkövetők, az eredményes nevelése csak intézményi körülmények között valósítható meg. A Büntetötörvénykönyv 1995-ös módosítása tette lehetővé, hogy a fiatalkorúak elözetes letartóztatásuk idejét javítóintézetekben tölthessék le, erre 1996. május 1-jét követően nyílt lehetőség. Ez azért 
jelentős lépés, mert a javítóintézetek szemléletében nem a büntetés, hanem a nevelés a domináns. A Btk. szerint a javítóintézeti nevelés időtartama egy évtől három évig terjedhet. A javító-nevelő intézetek az ágazati minisztérium irányítása alatt működnek, Aszódon, Rákospalotán, Debrecenben és Budapesten. Tevékenységük több szempontból is különleges, mivel pótolniuk kell a fiatalok tanulásbeli lemaradását, otthont biztosítaniuk számukra, ugyanakkor zárt intézményként müködnek. Több funkció jelenik meg az intézményen belül, ahogy ezt Ónodi Péter (2009), a debreceni javítóintézet működését -az intézmény szakmai programján keresztülbemutató dolgozatában összefoglalja. Így a javító-nevelő intézet betölti az iskola, a börtön, az otthon és gyakran a munkahely funkcióját is.

A javítóintézetek fó feladatai közé Hatvani-Papházi (2004) a szocializációs szint emelését, a kulturáltsági szint emelését, a családi életre nevelést, a munkavégzéshez szükséges képességek, készségek fejlesztését, a tanulási elmaradások pótlását, az erkölcsi fejlődés segítését sorolta. Volentics (1996) ezt a reszocializáció fogalmával egészítette ki, amely a fiatalok társadalmi integrációját egy komplex nevelési folyamatban látja megvalósíthatónak.

A társadalmi beilleszkedés hangsúlyozása mellett Herczog (2001) a javítóintézeti nevelés feladatának tartja az újabb büncselekmények elkövetésének megelözését.

Kutatásában Hatvani-Papházi (2004) arra a kérdésre kereste a választ, hogy kik kerülnek javítóintézeti nevelésbe, melyek a főbb statisztikai jellemzői a célcsoportnak. Vizsgálatuk eredménye azt mutatta, hogy nagy szerepe lehet a beilleszkedés elösegítésében az intézeteknek.

Kimutatható, hogy a javítóintézetekre azért emlékeznek szívesen a növendékek, mert az nem büntető jellegü, hanem a kölcsönös megértés és elfogadás révén igyekszik partneri kapcsolatot kialakítani velük, és segítő támogatásban részesíti őket.

A fiatalkori bünözésre vonatkozó statisztikai adatok szerint az 1991 és 1998 közötti időszakban az elítélt fiatalkorúak 100.000 azonos korú lakosra jutó száma átlagosan 884-röl 1505-re emelkedett. A fiúknál és a lányoknál a növekedés mértéke eltérő volt: míg a lányok száma 83 \%-kal, addig a fiúké 70 \%-kal emelkedett az időszak folyamán. (Vavró, 1999.) A kutatások adatai szerint a fiatalok körében a vagyon elleni büncselekmények elkövetése a legjellemzőbb. 
20. táblázat. Növendékek száma a beutalást megelözö állandó tartózkodási hely és a végzett tevékenység szerint 2005

\begin{tabular}{|c|c|c|c|c|c|c|c|c|}
\hline \multirow[b]{2}{*}{ Megnevezés } & \multirow{2}{*}{$\begin{array}{l}\text { Munka- } \\
\text { viszony- } \\
\text { ban }\end{array}$} & \multirow{2}{*}{$\begin{array}{l}\text { Al- } \\
\text { kalmi } \\
\text { mun- } \\
\text { kás } \\
\end{array}$} & \multirow[b]{2}{*}{$\begin{array}{l}\text { Szak- } \\
\text { képzó } \\
\text { iskolás }\end{array}$} & \multicolumn{4}{|c|}{ Nem dolgozott } & \multirow[b]{2}{*}{$\begin{array}{l}\text { ÖSSZE- } \\
\text { SEN }\end{array}$} \\
\hline & & & & $\begin{array}{l}\text { Kö- } \\
\text { zép-is- } \\
\text { kolás }\end{array}$ & $\begin{array}{l}\text { Álta- } \\
\text { lános } \\
\text { iskolás }\end{array}$ & $\begin{array}{l}\text { Gyógyped. } \\
\text { iskolás }\end{array}$ & \begin{tabular}{|l|} 
Nem \\
ta- \\
nult
\end{tabular} & \\
\hline $\begin{array}{l}\text { Vérszerinti } \\
\text { családban élt }\end{array}$ & 1 & 11 & 7 & 1 & 53 & 10 & 13 & 96 \\
\hline $\begin{array}{l}\text { Gyermekott- } \\
\text { honban élt }\end{array}$ & & 1 & 3 & 1 & 39 & 10 & 4 & 58 \\
\hline $\begin{array}{l}\text { Nevelőszülőnél } \\
\text { élt }\end{array}$ & & & & & 1 & & & 1 \\
\hline $\begin{array}{l}\text { Egyéb helyen } \\
\text { élt }\end{array}$ & & 3 & 2 & 1 & 5 & 3 & & 14 \\
\hline ÖSSZESEN & 1 & 15 & 12 & 3 & 98 & 23 & 17 & 169 \\
\hline
\end{tabular}

Forrás: Tájékoztató a család, gyermek- és ifjúságvédelem helyzetéről SZMM Gyermek- és ifjúságvédelmi föosztály 2006. 76. o.

A családi környezet fontosságát erősítik meg a 20. táblázat adatai. Megállapítható, hogy a legtöbb fiatal, 96 fó a nyilvántartott 169 föből, a vér szerinti családjából került a javítóintézetbe. A második helyen szerepel 58 fővel a gyermekotthonból bekerülő fiatalok köre. Az adatok alapján az is megállapítható, hogy a javítóintézeti fiatalok elsősorban nem a gyermekotthonok lakói közül kerülnek ki, bár ez a szám sem elhanyagolható.

Összességében megállapítható, hogy a javítóintézetek kettős funkciót látnak el. Egyrészt a büntetés, másrészt a nevelés funkcióját. Ezzel együtt a gyermekvédelmi szolgáltatásokat kiegészítik, mivel a bünelkövető gyerekek/fiatalok számára lehetôséget biztosítanak a társadalmi beilleszkedéshez, a fiatalok esélyt kapnak a bün nélküli élet feltételeinek a megteremtéséhez.

1997 előtt a gyermek- és ifjúságvédő intézetek feladata a gyámhatóságok által ideiglenesen „intézeti nevelésbe”, a bíróságok által ,állami nevelésbe” vett gyermekek ideiglenes befogadása, gondozása, átmeneti biztosítása volt. A gyermekés ifjúságvédelmi intézetekben csak átmeneti ideig, kb. 4-6 hétig tartózkodtak a gyermekek. Az átmeneti időben a szakemberek megfigyelték a gyermekeket, és állapotuknak megfelelő, szakmailag biztonságos elhelyezést javasoltak számukra. Az elhelyezés gyermekotthonokban vagy nevelöszülőknél történt.

Összefoglalva azt mondhatjuk, hogy a GYIVI-k a rájuk bízott gyermekek, fiatalok életútját az állami gondozás első pillanatától annak megszünéséig nyomon kísérték.

A Területi Gyermekvédelmi Szakszolgálat látja el a gyermek- és ifjúságvédő intézetek feladatait jelentős módosításokkal 1997 után. Ilyen intézmény minden 
megyében müködik, összesen 19. Elsősorban szolgáltatási feladatot végez, szorosan együttmüködik a gyámhivatallal. A gyermek gondozási helyének meghatározása érdekében elvégzi a személyiségvizsgálatát, és szakvéleményt készít. A gyámhivatal megkeresésére elkészíti a gyermek egyéni elhelyezési tervét is. Kijelöli az ideiglenes hatállyal elhelyezett gyermeket is befogadó nevelöszülöt és gyermekotthont. Müködteti a külső férőhelyeket az utógondozói ellátottak számára és a nevelőszülői hálózatot, valamint segíti az örökbeadásokat előkészíteni. Nevelőszülői tanácsadókat alkalmaz a nevelőszülők fogadására, felkészítésére, munkájuk ellenőrzésére. Hivatásos gyámokat, eseti gondnokokat alkalmaz a gyerekek ügyeinek képviselete érdekében.

A fejezetben összehasonlítottuk a család nélkül felnövő gyerekek elhelyezési lehetőségeit a Gyermekvédelmi törvény bevezetése előtti és utáni időszakban. Az összehasonlítás eredményeként megállapítható, hogy a gyerekek életkörülményei jelentősen javultak a törvény bevezetése után. A javulás több területen is megnyilvánul. A gyerekek elhelyezésében vezető szempont a családias körülmények biztosítása. Ez a törekvés megjelenik a nevelőszülői elhelyezés előtérbe kerülésével, illetve a lakásotthonok kialakításával. A vizsgált adatok szerint több gyermek él lakásotthonban, mint gyermekotthonban, és a gyermekotthonokban is törekedtek kisebb létszámú csoportok létrehozására. A gyerekek életkörülményeinek javítását szolgálja az új intézmények létrehozása. A különleges, a speciális és az utógondozó otthonok korszerübb tartalommal müködnek, mint a korábbi években. Jelentős probléma ugyanakkor, hogy kevés ilyen típusú intézmény áll rendelkezésre. A speciális ellátást igénylő gyerekek ellátása nehézkes, mivel a férőhelyek száma lényegesen nem bővült az elmúlt években. Az utógondozásra lehetőséget biztosító utógondozó otthonból is kevés van, miközben az utógondozói ellátottak száma nő. A gyermekek életkörülményeinek javulásához hosszabb távon az is hozzájárul, hogy a középfokú oktatási intézményekben többen tanulnak tovább, mint a korábbi években. Az intézmények törekednek arra, hogy a fiatalok legalább egy szakképzettséget szerezzenek. Ez körvonalazódik a fejezetben bemutatott továbbtanulásra vonatkozó adatok alapján. A szökések számának csökkenése is egyik mutatója lehet annak, hogy a gyerekek életkörülményei javultak az elhelyezési lehetőségek átalakulásával. 


\section{INTÉZMÉNYBEN ÉLŐ GYEREKEK AZ EMPIRIKUS KUTATÁSOK TÜKRÉBEN}

A fejezetben azokat az empirikus kutatásokat mutatjuk be, amelyek a gyermekvédelmi intézményekben elhelyezett gyermekek életkörülményeit vizsgálják. Elsősorban a gyermekotthoni/nevelőotthoni kutatásokat tekintjük át és kevéssé foglalkozunk a speciális és különleges gondozást igénylő gyermekek helyzetére vonatkozó vizsgálatokkal. Ennek oka az, hogy a gyermekvédelem e területei önálló kutatási témaként szolgálnak. Általában jellemző, hogy kevés országos, reprezentatív vizsgálat készült az elmúlt évtizedekben, a gyermekvédelemben, annak ellenére, hogy ez a kérdéskör erre bőven kínált volna lehetőséget. Mindezt kiegészítjük a magyar vizsgálatokhoz tematikusan kapcsolódó nemzetközi kutatások eredményeivel.

A szakirodalom áttekintése során kiemeljük Hanák (1978) kutatását, aki a 70-es években végzett alapozó, feltáró szociológiai kutatást Budapesten, amelyet hosszú ideig nem követett újabb. Ez a későbbi kutatások elméleti és módszertani megalapozását nagymértékben segítette. Több tényező alapján állítjuk azt, hogy Hanák (1978) vizsgálata megalapozta a későbbi kutatásokat, a gyermekvédelem tanulmányozását. Munkájában áttekintette a gyermekvédelem XX. századi történeti fejlődését, nemcsak elemezte azt, de rámutatott a különböző jelenségek társadalmi összefüggéseire is. Komplexen közelítette meg a gyermekvédelem kérdését. Értelmezte és definiálta a fogalmat - ahogy korábban már utaltunk rá-, ezzel jelentősen hatott a fogalomértelmezésekre. Az általa végzett vizsgálat több szempontból is újszerü volt. Az állami gondozott gyerekekről komplex helyzetértékelést készített. Erénye, hogy nemcsak a gyerekeket, de a szülőket is bevonta a vizsgálatba. Kutatásában gazdag módszertani repertoárt alkalmazott, így a kérdőíves felmérés mellett az interjúkészítést és a dokumentumelemzést is. Vizsgálta, hogy a szülök számára mit jelentett a gyermek családból való kiszakadása és fordítva. Egyrészt, hogyan élték meg a gyerekek a családdal töltött éveket, másrészt az állami gondozásba vétel élményét. A szerző 229 fő nevelőotthonban élő fiatallal végzett kérdőíves vizsgálatot. Interjút készített állami gondozottak szüleivel, illetve 21 olyan fiatallal, akik már kikerültek a nevelőotthonból. További vizsgálati módszerként a gyámügyi iratok elemzésével egészítette ki koncepcióját.

Az állami gondozásban élő gyerekek családi körülményeire vonatkozóan megállapítja, hogy a szülök többsége alacsony iskolai végzettséggel és alacsony keresettel rendelkezik. A vizsgálatba bevont állami gondozott gyerekek $90 \%$-ának szülei fizikai dolgozók. Körükben sok volt az egyszülős, valamint a sokgyerekes 
család. A gyerekek 95 \%- ának a szülei élnek, tehát nem elárvult gyerekek. A vizsgálatba bevont gyerekek $70 \%$-ának a testvére is állami gondozott volt. A családokra nagyfokú labilitás, fluktuáció volt jellemző.

Ezzel függ össze a családok képlékenysége is: könnyen engednek szélnek családtagokat, és könnyen fogadnak be újakat. A családi mikrokörnyezetet gyakorta a pillanatnyiság, a jelen érdekei uralják. (Hanák, 1978.)

A családok további jellemzője, hogy 71\%-uk egyszobás lakásban, 13\%-uk albérletben, 3\%-uk társbérletben élt, 8\%-nak pedig nincsen lakása. Az adatok rossz lakáskörülményekre utalnak, ami rendezetlen életmóddal társult, így ez a tényező gyakran képezte az állami gondozásba vétel okát. A bekerülés okait vizsgálva a gyámügyi iratok adatainak elemzéseiből is az derült ki, hogy a gyerekek $62 \%$-a a szülő elhanyagoló nevelése miatt került intézménybe. A szülők nem gondoskodtak a gyermek ellátásáról, sokszor még abban is akadályozták, hogy iskolába járjon. A gyermek elhanyagolása soha nem fordult elő egyedülálló okként, a szülők maguk is olyan rendezetlen körülmények között éltek, mint amelyet a gyermekeiknek nyújtottak. Az állami gondozásba vétel másik jelentős oka a szülők deviáns magatartása. Az állami gondozott gyerekek családjainak 74 \%-ában figyelhető meg deviáns magatartás az egyik vagy mindkét szülő esetében. A deviáns magatartás leggyakoribb formája az alkoholizmus. A családok 41 \%-ában maga a gyerek is antiszociális magatartású. Közülük 22\% iskolakerülö, 12 \% garázdaságot, 4 és 3 $\%$ lopást illetve betörést követett el.

A gyerekekkel készült interjúk azt mutatják, hogy a 80\%-uk elsősorban az állami gondozás előtti időszakban vele és családjával történt eseményeket tartotta fontosnak megemlíteni, annak ellenére, hogy ez csak egy rövid időszak volt az életükben. A gyerekek életének középpontjában a nevelőotthon előtti élet, a család állt. Ez azért is érdekes, mert a családhoz kapcsolódó kulcsszavak között első helyen a verést említették a gyerekek. A társadalmi beilleszkedésükre vonatkozóan a következő megállapítást teszi a szerző: azoknak sikerül ez nagyobb konfliktusok nélkül, akik valamilyen társadalmi-főként munkahelyi- támogatást kaptak önálló életük kiépítéséhez, a hátrányok leküzdéséhez. (Hanák, 1978)

A kutatás felhívja a figyelmet az állami gondozott lét újratermelődésére is. Az állami gondozottsággal járó hátrányok az állami gondozottság utáni életszakaszra is kihatnak. Ilyen hátrány lehet például a család támaszának hiánya, általában az alacsony iskolai és szakmai végzettség, a lakáshiány, az önálló élet megteremtéséhez szükséges készségek hiánya, a több irányú beilleszkedési nehézség stb. Ezek a tényezők egymással találkozva és egymás hatását felerősítve reprodukálják azokat a körülményeket és okokat, amelyek a volt állami gondozott szülő gyermekénél is gyakran elkerülhetetlenné teszik a gyermek állami gondozásba vételét. Az állami gondozott családok újratermelődése tehát nemzedékről-nemzedékre áthagyományozódott objektív és szubjektív hátrányok megmaradásával, továbbélésével magyarázható. (Hanák, 1978) 


\subsection{Elhelyezési körülmények}

A gyerekek életkörülményeit lényegesen befolyásolja, hogy milyen típusú intézményben kerülnek elhelyezésre, a következőkben az erre vonatkozó kutatásokat tekintjük át. Vidra-Szabó Ferenc (2001) Az állami gondozottak értékvilága címü OTKA kutatásban azt vizsgálta, hogyan valósult meg a gyermekvédelmi intézményrendszer átalakítása, milyen a gyerekek helyzete az intézményekben. A vizsgálatba 1116 fö 18 évesnél fiatalabb gyermek iratanyagát vonta be, összesen 26 fóvárosi és vidéki gyermekotthonból. A kutatás módszere az iratanyagok elemzése, interjúk készítése volt. Gyermekeket, pedagógusokat és gyermekvédelmi szakembereket kérdezett meg. A gyerekek családi hátterére vonatkozóan megállapította, hogy gyakori a szülők válása, a különélés, az élettársi kapcsolat. A vizsgálatba bevont iratanyagok alapján a szerző arra a megállapításra jutott, hogy a gyerek helyzetéért a vizsgálatba bevont esetek közül 721-ben a szülö felelős. A bekerülés leggyakoribb oka az alkoholfogyasztás és a vele összefüggő agresszió. Vidra-Szabó (2000) Hanákhoz (1978) hasonlóan azt találta, hogy a gyerekek többségének legalább az egyik szülője él, és igen gyakori, hogy elhagyják a gyereküket. Az általa vizsgált esetek közül 322-ben egyik vagy mindkét szülő elhagyta a gyereket. A kutatás szerint leggyakrabban az anyák kezdeményezik a gyerek állami gondozásba kerülését, második helyen a rendőrség áll, majd 3 helyen a fiatalok saját maguk kezdeményezték az intézményes nevelést. A feltárt esetek 1/3-ban a gyereknek semmilyen külső kapcsolata nincs. 1/3-nak az anyákkal van szorosabb-lazább kapcsolata. Az apák közül minden 10. tart kapcsolatot a gyerekkel.

A vizsgálatba bevont minden második gyermeknek a testvére is állami gondozott. A nagyszülő fontos kapocs lehet, mert ők gyakran átveszik a lecsúszott szülök szerepét. A vizsgálatba bevont gyerekek 1/10-ét a szülők hazavitték, de visszakerültek az intézménybe, mert a család nem tudta befogadni, a gyerek pedig nem tudott beilleszkedni korábbi környezetébe. A hazakerülők 77\%-a két évnél rövidebb időt töltött el családi környezetben. Ezen belül $42 \%$-uk egy évet sem volt otthon. A kutatásból az is kiderült, hogy a visszakerült gyerekek más otthonba kerültek vissza, nem az eredeti helyükre. A vizsgált 1116 esetből 703 alkalommal volt váltás. A gyerekotthonban élő gyerekek $40 \%$-a már több áthelyezést is átélt. (Vidra-Szabó, 2001)

A jelenlegi gyermekotthoni struktúra nem alkalmas a gyerekek értékzavarainak a korrigálására. Az intézetben felnövekvő gyerekek kettős értékvilágban élnek, kettős értéktudatuk alakul ki. A formális mezőben jelennek meg az intézmény vélt és hirdetett eszméi: szeretet, közösségiség, becsületesség, önfeláldozás, vallásos hit stb. A formális világ ebből következően meglehetősen szürke, sematikus viszont feladatrendszere könnyen teljesíthető, törvényei jól átláthatóak, könnyedén megtanulhatóak. 
Az informális mezőben a mélyben lappangó, ám valóságosan működő normák, erőviszonyok és müködési szabályok bújnak meg. (Vidra- Szabó, 2001)

Arató- Csizmadia- Szabó (2002) a különböző típusú nevelőotthonokat hasonlította össze. Arra a kérdésre keresték a választ, hogy a telepszerüen müködő, hagyományos otthonok leválasztásával létrejött otthonokban illetve az önálló családi házban müködő lakásotthonokban milyenek a nevelési eredmények, miben tér el egymástól a két típus, és ezek milyen életkörülményeket biztosítanak a gyerekek számára.

A vizsgálatban 85 fö 10 és 18 év közötti gyermeket kérdeztek meg, valamint 15 fö nevelőt. Módszerként a kérdőívet választották, ami 55 állítást tartalmazott. A kutatók feltételezték, hogy az önálló, kihelyezett lakásotthonban élő gyerekek elégedettebbek, kapcsolataik pozitívabbak, gazdagabbak, mint a telepszerü körülmények között élő társaiké. Jobban kötődnek az élőhelyükhöz, és jobban beleszólhatnak az öket érintő kérdésekbe.

A kihelyezett csoportokban élő gyerekek szignifikánsan elégedettebbek az életükkel, a helyzetükkel, és az őket befogadó csoporttal. Az önálló lakásotthonban élő gyerekek kapcsolatrendszere szignifikánsan gazdagabb. A kihelyezett lakásotthonokban könnyebben alakul ki a pozitív kötődés, esetleg erős elkötelezettség. Általában ez a családban élő gyermekek számára természetes. Az önálló lakásotthonban élő gyerekek közül többen érzik úgy, hogy beleszólhatnak az életükbe. Kutatásuk eredményei alapján egyetértettek azokkal a szakemberekkel, akik az önálló, kis létszámú, (egy csoportból álló) családias nevelőotthonok mellett érvelnek. A vizsgált két nevelőotthon-típus közül is inkább ebben kötődnek a gyermekek erősebben, pozitívabban fizikai és szociális környezetükhöz. (Arató -CsizmadiaSzabó, 2002)

A gyermekvédelmi szakellátás átalakítására vonatkozóan végzett kutatást Berényi és munkatársai (2004). Azt vizsgálták, hogy a gyermekvédelmi törvény hatására hogyan alakult a gyermekvédelmi szakellátást biztosító intézmények rendszere, rendelkezésre állnak-e a gyermekvédelemhez szükséges ellátási formák. Helyszíni vizsgálatot végeztek az Egészségügyi Szociális és Családügyi Minisztériumban, a fővárosi és 9 megyei önkormányzatnál, egy megyei jogú városban, 10 gyermekvédelmi szakszolgálatnál, 11 gyermekotthonban, 10 lakásotthonban, 2 utógondozó otthonban, 1 befogadó otthonban és 11 nevelőszülői hálózatban. A vizsgálat 14933 föt érintett, ez a 2002-es évben, a szakellátásban részesülő gyerekek $68 \%$-át jelenti.

Az intézményekre vonatkozóan a következő megállapítások születtek. A gyermekvédelmi szakellátást végző intézmények átalakítása a konkrét eredmények ellenére lassan haladt elöre, alapvetően az ehhez szükséges források hiánya miatt.

A szabályozás prioritásként kezeli a kis létszámú családias körülményeket biztosító, maximum 12 férőhelyes lakásotthonok kialakítását, ahol biztosítható az egyéni törődés, könnyebbé válik a fiatalok társadalmi beilleszkedése. 2002-ben 
a gyermekotthonok átalakításának eredményeként a férőhelyek egyharmada lakásotthoni férőhely, ez 31\%-kal magasabb, mint 1999. évben. A Gyermekvédelmi törvény hatályba lépése előtt már elkezdődött a nagy létszámú gyermekintézmények átalakítása. Kisebb szakmai egységeket, családias közösséget próbáltak a nagy otthonok falai között kialakítani. Az épületek adottságai, a foglalkoztatott dolgozók érdeke és nem utolsósorban a fenntartó önkormányzatok pénzügyi pozíciói hatására a gyermekvédelmi törvényt követően is maradtak meg korábbi nagy intézményeknek helyet adó épületekben gyermekotthonok. Ezekben több szakmai egységet hoztak létre, melyek különálló gyermekotthonként müködnek. Az intézményi átalakítást a kastélyépületek kiváltását jellemzően a lakásotthonok vásárlásával oldották meg a fenntartók. A vizsgált megyék egyikében sem fejeződött be a gyermekvédelmi szakellátást biztosító intézmények teljes körú átalakítása és kiváltása. (Berényi és mtsai, 2004)

A gyerekek elhelyezési lehetőségeivel kapcsolatban megállapították, hogy a gyermekgondozás helyének kijelölését alapvetően a szabad férőhelyek befolyásolják. A területi gyermekvédelmi szolgálatokhoz tartozó gyermekvédelmi szakértői bizottságnak kell 2003- tól - a gyermek vizsgálata alapján - meghatároznia a gyermek érdekeinek megfelelö helyet. A gyakorlatban azonban a bizottság csak a szabad férőhelyek alapján hozhatja meg javaslatát a gondozás helyére vonatkozóan, ezért a szakellátásba bekerülő gyermekek nem minden esetben kerülhetnek a számukra legmegfelelőbb ellátást nyújtó gondozási helyre. A gyermekek nevelőszülőknél történő elhelyezése szakmailag optimális megoldás. A feladatellátásra alkalmas nevelőszülők hiányában a nevelőszülöi hálózatok nem fejleszthetők korlátlanul. A kamaszkorú gyermekek gyakran súlyos magatartási problémákkal, különböző szenvedélybetegségekkel küzdenek, és a gondozásukhoz szükséges feltételeket (elhelyezési körülmények, megfelelő szakmai ismeretek) a nevelőszülők nem tudják biztosítani. A jelenlegi rendszerben a hagyományos nevelőszülők szeretnék megválogatni gondozottjaikat, a tapasztalatok szerint a problémás, idősebb, kamaszkorú gyermekek gondozását nem vállalják, ragaszkodnak a csecsemő vagy óvodáskorú gyermekek befogadásához. (Berényi és munkatársai, 2004)

A 18. életévüket betöltött fiatalok közül egyre többen veszik igénybe az utógondozói ellátást. A vizsgált időszakban számuk az életkezdési nehézségek és a továbbtanulási kedv növekedéséből adódóan 5,6\%-kal, 4080 före emelkedett. Az utógondozói otthonok és az elhelyezést szolgáló külső férőhelyek száma kevés. A gyermekotthoni féröhelyek 4-5 \%-ban láttak el az 1999-2002 években utógondozottakat.

Az utógondozói ellátás megszünésével, a 24. életév betöltésével a fiataloknak lakhatásukról, megélhetésükröl önmaguknak kell gondoskodniuk. Az alanyi jogon járó otthonteremtési támogatás alacsony összege viszont nem jelent reális lehetőséget a lakásmegoldásra. Lakásvásárláshoz hitelhez ezek a fiatalok másoknál kevesebb eséllyel jutnak rendszeres jövedelem és hitelfedezet hiányában. (Berényi és munkatársai, 2004) 
A lakásotthonban élő gyerekek közérzetét, elégedettségét, elhelyezési körülményeit vizsgálta Zsámbéki (2004). 27 lakásotthonból összesen 176 gyerekkel készítettek interjút a gyámi tanácsadók. Az interjúkérdések elsősorban a bekerülés körülményeit, a családi vagy korábbi baráti kapcsolatok alakulását, a lakásotthoni körülményeket, a felnőttek állandóságát, a társadalomba ágyazottságot, a lakásotthonhoz füződő érzelmi viszonyt, a gyermeki jogok érvényesülését taglalta.

A megkérdezett gyerekek nagy része a korábbi gyermekotthonok kiváltásával került a lakásotthonba. Többségüknek (50,5\%) volt információja arról, hogy hová fog kerülni. A gyerekek többségének (82,4\%) van kapcsolata a családjával. 57,4\%uk nem tart kapcsolatot korábbi barátaival, ismerőseivel. Figyelemreméltó az az adat, hogy 101 gyermeknek megszakadtak a fontos kötődései. A korábbi baráti viszonyok alakulására két dolog jellemző. Egyrészt, minél régebben utalták be a gyermeket a szakellátásba, annál kevésbé maradnak meg ezek a kapcsolatok, a gyerekek nagy része idővel beletörődik ezek elvesztésébe. Másrészt nyilvánvaló, hogy a megmaradt baráti kapcsolatok zömmel a korábbi gyermekotthoni társakra redukálódnak. (Zsámbéki, 2004)

Arató-Csizmadia-Szabó (2002) eredményeihez hasonlóan Zsámbéki (2004) is azt találta, hogy a lakásotthoni elhelyezési körülményekkel a gyerekek többsége $(81,8$ \%) elégedett. Az itt élő gyerekek gazdag társas kapcsolatrendszerrel rendelkeznek, aktívan vesznek részt az önálló életre való felkészülésben. A nagyobb bevásárlásokat többnyire a lakásotthonban dolgozó felnőttek végzik, míg a napi kisebb vásárlásokat a gyerekekre bízzák. A megkérdezettek többsége - 122 fő - nem titkolja, hogy nem saját családjában, hanem lakásotthonban él. (Zsámbéki, 2004).

A gyermekotthonban élő, nagykorúságuk előtt álló fiatalok társadalmi integrációs esélyeit vizsgálta Rácz Andrea (2006). A kutatásban a hagyományos gyermekotthon és lakásotthon müködését, az ott folyó szakmai munka megismerését, az ott nevelkedő fiatalok életkörülményeinek vizsgálatát tüzte ki célul. 6 intézményt keresett meg, ahol strukturált interjút készített az intézmény vezetőivel, nevelőivel a szervezeti, szakmai problémák megismerése érdekében. 31 fő nagykorúság előtt álló fiatallal készített interjút annak feltárására, hogy milyen a kapcsolatuk a nevelőkkel, saját családjukkal, milyen a párkapcsolatuk, illetve mi az elképzelésük az önálló életükről, kitől milyen segítséget várnak az önálló élet megkezdéséhez. További 4 interjú készült döntéshozókkal a gyermekvédelmi rendszer fejlesztési lehetőségeinek feltérképezésére.

A vizsgált gyermekotthonok többféle belső szervezeti formában müködnek. A vizsgáltak között volt olyan gyermekotthon, ami a nagy létszámú gyermekotthon részleges kiváltásával jött létre, szervezetileg az anyaotthon mellett müködik. Volt közöttük olyan, amelyben belső lakásotthoni egységeket hoztak létre, és nem tartozott hozzájuk külső lakásotthon. A lakásotthonok között vannak olyanok, amelyekben szervezeti felépítését tekintve több lakásotthon tartozik egy szakmai vezetés alá. A lakásotthon és a gyermekotthon közötti különbség a kutatás szerint abban van, 
hogy a lakásotthon sokkal inkább az életre tudja felkészíteni a gyereket, de a hogyan nem tisztázott. Átmenetinek tekinthetjük az átalakulást követően a jelen intézményi müködést, ameddig csak formálisan deklarált nevelési elvek, célok, módszerek szolgálják az önálló életre való felkészítést. A szervezeti müködésre vonatkozóan megállapítható, hogy a nagy létszámú nevelőotthonok külső részleges vagy belső tagozódású kiváltása a belső iskola megszüntetésével kezdődött a legtöbb esetben. A rendszer átalakításának útját a törvény egyértelművé tette, ugyanakkor megalapozott szakmai koncepció, szakmai iránymutatás, vagy egy olyan szakembergárda, amely ezt moderálta volna, nem állt rendelkezésre. (Rácz, 2006)

Új eleme a kutatásnak a nevelőkkel készült interjú. A nevelők számára új feladatnak bizonyult, hogy saját család mintájára kell az intézmény életét megszervezni, főleg a napi tevékenységek szervezése igényelt komoly változtatást. Megszünt a „tömegben mozgatás”, nem kellett szigorú időbeosztáshoz alkalmazkodni. A nevelési elveket és módszereket is a megváltozott körülményekhez kellett volna igazítani (szakmai elvek mentén), de ehhez egységes szakmai iránymutatás, úgynevezett nevelési standardok nincsenek, így a pedagógiai módszerek, az értékközvetítés többnyire egyéntől függőek. (Rácz, 2006)

Zsámbéki (2004) és Arató- Csizmadia- Szabó (2002) eredményeihez hasonlóan Rácz (2006) is az önálló életre való felkészítésben látja a lakásotthon előnyét a gyermekotthonnal szemben. Ugyanakkor kiemeli, hogy ennek a módszerei kevéssé tisztázottak.

A korábbi kutatásokhoz hasonlóan ez a kutatás is alátámasztja, hogy a fiatalok alacsony iskolai végzettséggel rendelkeznek, és a gyermekotthonra, lakásotthonra hárul a gyerekek felzárkóztatása. Az iskola elöítéleteivel a gyermekvédelmi gondoskodás alatt álló gyermekeknek meg kell küzdeniük, mert a családban nevelkedő társaik, azok szülei, de számos esetben a pedagógusok is kirekesztik őket.

A gyerekekkel készített interjúk szerint a gyermekek rendelkeznek jövőképpel, de ez sok esetben elrugaszkodik a valóságtól, nincsenek tisztában a pénz értékével, illuzórikus elképzeléseik vannak a lakhatáshoz, a munkához jutásról.

Ugyanakkor fontos látni, hogy az intézmények egy vagy több szakma elsajátítását, a felsőoktatási rendszerben való megjelenést hangsúlyozzák, ami a jövő megalapozása szempontjából elsőként megjelenített érték. (Rácz, 2006)

\subsection{Szabadidő}

A szabadidős tevékenységek támogatják az intézmények munkáját abban, hogy a gyerekekre irányuló gondoskodó, védelmező, kompenzáló funkcióikat teljesíteni tudják. A gyerekek számára is segítséget adnak ahhoz, hogy a veszélyeztető tényezőkkel hatékonyabban tudjanak megküzdeni, az őket ért traumákat fel tudják dolgozni. A szabadidő eszközül szolgálhat továbbá azon képességek, készségek 
fejlesztéséhez, amik a gyerekek jövőben felmerülő problémáinak a megoldásához szükségesek. (Gilligan, 1999)

A szabadidő mennyisége és minősége jelentősen befolyásolja az intézményben elhelyezett gyerekek életkörülményeit. Az intézményekben élők szabadidős szokásaira vonatkozóan kevés önálló kutatás áll rendelkezésre, de a téma több kutatás részét képezi.

A nevelőotthonban élő gyerekek életmódját, csoportszerkezetét, szabadidős tevékenységét vizsgálta Hazai- Volentics (1986). A kutatás további célja a nevelőotthoni életmód megváltoztatása, a szabadidős tevékenységek gazdagítása volt. 17 nevelőotthonban 31 közösséget kérdeztek meg, összesen 451 gyereket. Módszerként a kérdőívet, a dokumentumelemzést, a szociometriát, az Irle-Csirszka-féle érdeklődésvizsgálatot, és az időmérleg készítését választották. Meghatározó szerepe volt a nevelőotthoni életmódkutatásban az időmérleg vizsgálatnak. Egy hétvégi és egy hétköznapi nap tevékenységrendszerét figyelték meg. Az étkezésre fordított idő mennyiségét kevésnek találták. Ez nehezíti a helyes étkezési szokások kialakítását. Ugyanez igaz a személyi higiéniára fordított időre is, ami nem volt több napi 15 percnél. Jelentősnek találták viszont a tanulásra fordított idő mennyiségét, ami naponta 132 perc volt. A nevelési dokumentumokból azonban az is megállapítható, hogy a jelentős mennyiségü tanulási idő általános jellemzője a hétköznapi nevelöotthoni életnek. (Hazai-Volentics, 1986)

A szabadidő eltöltésére vonatkozóan megállapították, hogy tényleges sporttevékenység csak 11 csoportban található, pedig a sport fontos személyiségformáló eszköz. Kultúrálódást szolgáló tevékenységek (mozi, színház, rádió, hangverseny, tévénézést soroltuk ide) a tévé- nézés kivételével igen kis számban szerepeltek. E tevékenységek éves szinten megjelenő gyakoriságát is figyelembe véve azt állították, hogy a nevelőotthon a kulturális értékek elsajátítását, mint fontos szocializációs feladatát nem jó szinten, úgy tünik, hogy túlzottan a tv-re hagyatkozva látja el. (Hazai-Volentics, 1986)

A nevelőotthoni életmód jellemzője az ún. kettős zártság, amely abban nyilvánul meg, hogy a gyermekek a nevelőotthonon és a saját csoportjukon kívül csak korlátozott időtartamot tölthetnek. A kettős zártságra mutat az a tény is, hogy elenyésző gyakorisággal lépnek be külső személyek a nevelőotthon, az egyes csoportok életébe, és hogy a külső kapcsolatok teremtésének szinte kizárólagos színtere a nevelőotthonon kívüli iskola. (Hazai-Volentics, 1986)

Egy másik a korábbiakban hivatkozott kutatásban szintén a tévé nézést találták a lakásotthonokban élők körében fő szabadidős tevékenységként. A gyerekek válaszaiból az derült ki, hogy szervezett külső programokról mindenhol igyekeznek gondoskodni. Többnyire tévénézéssel és számítógépezéssel töltik az időt. Csak 49 gyerek mondta azt, hogy a hétvégéken nincs semmilyen közös program. A leggyakrabban kirándulni mennek, vagy csak egyszerüen sétálnak a városban. Ezek nem költségigényes és könnyen megvalósítható házon kívüli programok. (Zsámbéki, 2004) 
Elsősorban az alkohol- és drogfogyasztást kutatta Elekes-Paksi (2005) az intézményben élő fiatalok körében, de kitért a szabadidős tevékenységek vizsgálatára is. A számítógépes játékot találták a leggyakoribb szabadidős programnak. A kutatók összehasonlították a gyermekvédelemben és a családban élő gyerekek szabadidős szokásait, és azt találták, hogy a gyerekek gyakran töltik otthonülős programmal a mindennapjaikat. (Elekes-Paksi, 2005.)

\subsection{Iskolázottság}

A volt állami gondozottak társadalmi beilleszkedését segítő és nehezítő tényezőiről adott áttekintést Hanák (1985). Kiemelt figyelmet fordított az iskolázottság kérdésére. A kutatásban 19-28 éves volt állami gondozott fiatalt kérdeztek meg. Módszerként a mélyinterjút alkalmazták, és 48 fövel készítették el. A következő helyzetkép született a társadalmi beilleszkedést befolyásoló főbb tényezőkre a - nevelőotthoni nevelésre, a családdal való kapcsolattartásra, az iskolázottságra, a munkahelyi beilleszkedésre, a devianciákra- vonatkozóan. A válaszadók 1/5-e szerint a nevelőotthon semmire nem készít fel. A másik ötöde az önállóságra való felkészítést nevezte meg erényként. A többiek viszont hiányolták az önállóságra nevelést, a mindennapi életben való eligazodáshoz szükséges ismereteket. Ugyanakkor elismerően szóltak arról, hogy a nevelőotthon iskoláztatta, rendre nevelte és szakmára taníttatta őket.

A kutatásban a fiatalok két nagy csoportja rajzolódott ki. Az egyik az önbíráskodó, akiben kialakult az állandó készenlét az ôt ért valós vagy vélt sérelmek önhatalmú visszafizetésére.

Ő az, aki konfliktuskezelési nehézségekkel küzd és mindenre agresszíven reagál. A másik csoport a megfélemlített „nyuszi”, aki nem tud sehol egyenrangú partnerkapcsolatot teremteni, és nem mer szólni, a sérelmeket az élet törvényének tekinti.

A családdal való kapcsolattartásra vonatkozóan megállapítható, hogy a gondozottak több mint felének megszünik, meglazul, érzelmileg kiürül a családdal, testvérekkel való kapcsolata. A volt állami gondozottak fele visszaköltözött ugyan a családhoz, mert más megoldást nem talált. Amennyiben a család nem tudta vagy nem akarta visszafogadni, maradt az ágybérlet, az albérlet és a munkásszálló. Azt is megállapították, hogy nem ugyanahhoz a családhoz költöznek vissza a fiatalok, hanem rosszabbhoz. Felmerült a kérdés, miért nem történik semmi, hogy a családok visszanyerjék épségüket, és alkalmassá váljanak a szerepek betöltésére, és ne csússzanak lejjebb. A szerző azt is megállapítja, hogy a volt állami gondozottak gyerekei közül is jó néhány ugyancsak állami gondozásba kerül. A megkérdezettek 10-15 százaléka folyamatosan, nemzedékről- nemzedékre állami gondozásba adja a gyermekét. (Hanák, 1985) 
Az iskolázottságra vonatkozóan kiderült, hogy a szülők meglehetősen alacsony iskolázottsági, szakképzettségi szintjéhez képest a volt állami gondozottak mindenképpen iskolázottabbak, szakképzettebbek. A nagy többség elvégezte az általános iskolát, a lányok 40, a fiúk 46 százaléka megszerezte a szakmunkás végzettséget. Jellemző a lemorzsolódás is, de ez összefügg azzal, hogy az állami gondozottak az átlagosnál gyakrabban szorulnak kényszerpályákra, vagyis kisebb lehetőségük van a szakmaválasztásra. A kényszerpályák a lemorzsolódáson kívül abban is megbosszulják magukat, hogy a szakmunkás bizonyítványt szerzettek közül jó néhány nem a szakmájában, hanem betanított munkásként vagy segédmunkásként dolgozik. Többeknek beilleszkedési problémája van a munkahelyen. Ez a kutatás szerint a fiatalok türelemének hiányára, a munkaszervezethez való alkalmazkodás nehézségeire, és a munkahelyi elöítéletekre vezethető vissza. (Hanák, 1985)

A volt állami gondozottak önálló életkezdési lehetőségeit, a gyerekek iskolázottságát kutatta Veres-Brezovszky (1990). A kutatásba az 1983-84-ben nagykorúvá vált fiatalok 60\%-a került be véletlenszerü mintavétellel, illetve ezt egészítette ki a gyermek- és ifjúságvédő intézményekben található dokumentumok elemzése.

A gyermekek iskolázottsági mutatóira vonatkozóan vizsgálatuk adatai megerösítik azt a közismert tényt, hogy az állami gondozottak körében az iskolai végzettség jelentősen elmarad az azonos életkorú, nem állami gondozott fiatalok iskolai végzettségének országos átlagától.

Amikor a képzettségi szint belső szerkezetét vizsgálták, azt tapasztalták, hogy az állami gondozottak körében a képezhetetlenek, analfabéták, illetve az általános iskola nyolcadik osztályát el nem végzettek aránya magasabb (25\%-kal) az 1980as népszámlálási adatok szerinti országos átlagnál. (Veres-Brezovszky, 1990)

A szerzők Hanákhoz (1978) és Vidra-Szabóhoz (2001) hasonlóan megállapították, hogy az állami gondozott gyerekek elsősorban többszörösen hátrányos helyzetű perifériális szubkultúrából kerülnek az intézményekbe. A mintában szereplő minden harmadik gyermek (32,1 \%) cigány származású volt. A bekerülés okaként a leggyakrabban a szülök deviáns életmódját jelölték meg. A 0-3 évesek szüleinek 57,5 \%- ánál, a 15-18 évesek szüleinek 48\%-ánál van feltüntetve egy vagy több deviancia az állami gondozásba vétel okaként. A 15-18 éves korukban bekerülőknél előtérbe kerül a gyermek saját devianciája (31\%-nál) illetve magatartási problémája (53\%-nál). A gyermek devianciáját a család felbomlási folyamatának egyik eredményekét értelmezhetjük. (VeresBrezovszky, 1990)

A kutatók felhívják a figyelmet arra, hogy a családi miliö, mint bekerülési ok mellett az állami gondozás intézményrendszerének napi pedagógiai gyakorlatában is számos olyan ok és körülmény lehet, ami jelentős hatással van az iskolai pályafutásra. (Veres-Brezovszky, 1990) 
Az állami gondozottak iskolai pályafutását, a gyermekvédelem intézményrendszerének iskoláztatásra gyakorolt hatását vizsgálta Hazainé-Csókay (1990). 61 nevelőotthon összesen 5829 növendékét kérdezték meg kérdőíves módszerrel. A kutatásban 5 tanév, 1981-1986 alsófokú oktatási és gyermekvédelmi statisztikai adatait vizsgálták. A kutatás fontos szempontja volt, hogy mekkora az otthon mérete, illetve, hogy külső vagy belső iskolába járnak-e a gyerekek. A vizsgált otthonok növendékeinek az elmúlt öt évre vonatkozó összesített tanulmányi átlaga alapján megállapították, hogy a külső és a belső iskolában elért átlageredmény között kicsi a különbség.

Veres - Brezovszky (1990) eredményeihez hasonlóan a túlkorosság megjelenik problémaként ebben a vizsgálatban is. A nevelöotthonok esetében gyakori a gyerekek 2-3 éves lemaradása, de nem ritka a 4-5 éves túlkorosság sem. Alsófokú nevelési statisztikai adatok szerint az általános iskolások 3-5 \%-a nem iskolaérett. A gyermekvédelmi statisztika ezzel szemben a hat éves állami gondozottak 28-45 \%-át jelzi nem iskolaérettnek. (Hazainé-Csókay, 1990)

A továbbtanulásra vonatkozóan a kis otthonok jobb eredményeket értek el. 1985/86-os tanévben az általános iskola befejezése után az állami gondozott gyerekek 82\%-a tanult tovább. Hanákkal (1985) megegyezően ez a kutatás is azt mutatta, hogy az állami gondozottak szakmaválasztási lehetősége behatárolt, a gyenge tanulmányi eredmény a bizonytalan pályaelképzelés, valamint a pályairányítási gyakorlat miatt. A vizsgált időszakban 100 gyermek került áthelyezésre kisegítő iskolába. A megalapozatlan áthelyezésekre hívja fel figyelmünket az a tény, hogy a gyermekvédelmi statisztika szerint az állami gondozottak közel 30\%-a kisegítő iskolás, szemben a családban élők 2,4- 2,5 \%-os arányával. (Hazainé-Csókay, 1990)

Akedvezőtleniskolaieredményekmiattanevelőotthonokbanjavítanikellaszocializációnakaziskoláztatástelőmozdító feltételeit. Segítenikell agyerekeknek, hogyne maradjanak le az iskolában, korrekciós foglalkozások, felzárkóztatás biztosításával. A szociometriai vizsgálat megerősítette, hogy a 7-12 létszámúnál nagyobb csoportokban kisebb eséllyel alakul ki jó belső kohézió és arányos, kedvező csoporttagozódás. Az ennél nagyobb csoportlétszámnál könnyebben jönnek létre elkülönülő alcsoportok, klikkek. (Hazai, 1984)

Egy másik kutatásban szintén a gyermekvédelmi intézményekben élő gyerekek iskolai karrierjének alakulását vizsgálta Hodosán-Rácz (2009). Kérdőívet vettek fel 208 középfokú képzésben résztvevő fiatallal, amelyet 20 interjúval egészítettek ki. A megkérdezettek 36,9\%-a élt gyermekotthonban. A kérdezettek többsége (72,8\%) normál tagozatú, 15,5\% speciális osztályba járt a középfokú képzés megkezdése elött.

A korábbi kutatásokhoz hasonlóan a kutatók itt is azt találták, hogy a megkérdezettek körében magas a bukások, osztályismétlések aránya. (Veres-Brezovszky, 1990, Hazainé - Csókai, 1990). 33\% ismételt évet, ez azt jelenti, hogy minden harmadik gyermek kényszerült erre az általános iskolában. Többségük (57\%) az 
osztályismétlést rossz tanulmányi eredményének köszönheti, de $22 \%$-ukat a családi problémák nehezítették a sikeresebb iskolai teljesítmény elérésében. Az igazolatlan hiányzás 14\%-ban vezetetett osztályismétléshez, míg egészségügyi problémák miatt csak két fiatal jutott erre a sorsra. Sajnálatos módon 17\% túlkorosan, 16 évesen vagy annál idősebben szerzett általános iskolai bizonyítványt. (Hodosán - Rácz, 2009)

A fiatalok többsége (48\%) érettségit és szakmát is adó képzésben kívánt továbbtanulni, és $41 \%$ preferált valamilyen szakiskolát. Nagy részük (78\%) jelenlegi iskoláját jelölte meg első helyen, viszont 44 fiatal nem ide szeretett volna bekerülni. A szakma megszerzése után a fiatalok egy jelentős része munkába kíván állni.(Hodosán-Rácz, 2009)

A megkérdezettek iskolai magatartási problémákról is beszámoltak, ez legnagyobb arányban az igazolatlan hiányzást, a dohányzást és a tanárokkal való tiszteletlen viselkedést foglalta magában. A kutatók a középiskolai tanulás során is magasabb arányú (20\%) bukásról számoltak be az intézményekben élö fiatalok körében, mint a szakiskolai tanulók országos átlaga (13\%). Annak ellenére, hogy a fiatalok járnak felzárkóztatásra.

A fiatalok $85,1 \%$-a úgy gondolja, hogy az iskola felkészíti öket a munkavállalásra, viszont $75 \%$ szerint csak átlagos tudásra tesznek általa szert, ami nem biztos, hogy a munkaerőpiacon elegendő. (Hodosán-Rácz, 2009)

A megkérdezettek többsége úgy véli, hogy a gyermekvédelmi gondozási háttérrel jobb eredményt tudnak elérni a tanulásban, mintha saját családban élnének. Tanulási probléma esetén elsősorban a gyermekvédelemben dolgozó szakemberektől kérnek segítséget a fiatalok, őket követik a tanárok, a barátok, a lakótársak. A gyermekvédelmi gondoskodás oktatási szempontból való felértékelődése abból látszik, hogy a fiatalok $44 \%$-a szerint a nevelkedési háttér nem játszik szerepet abban, ki hogy tanul.

A húsz fiatallal készített interjú alátámasztotta, hogy az iskolai lemorzsolódást befolyásolja többek között a gyakori gondozási helyváltás, a fiatalok tanulással szembeni negatív attitüdje, az iskolával való elégedetlenség, a kevés tanulásra fordított idő, a munkaerőpiacon való minél előbbi részvételi szándék, az irreális jövőkép, a tanácstalanság, sodródás. (Hodosán-Rácz, 2009)

\subsection{Alkohol, drog, dohányzás}

Nevelőotthonban élő fiatalok körében végzett kérdőíves vizsgálatot SzabolcsSzatmár-Bereg megyében Murányi (2000). 263 fő állami gondozásban élő fiatalt kérdezett meg. A kutatás célja a legális és illegális drogok kipróbálásának, alkalomszerü vagy rendszeres fogyasztásának a feltárása. 
A kutatás szerint a fiatalok 35\%-a már kipróbálta a cigarettázást, egyötödük (21 százalék) még soha nem dohányzott, azonban a relatív többség (44 százalék) rendszeres dohányzó. A fiatalok fele (53 százalék) életében már többször ivott szeszes italt, rendszeres fogyasztónak csak 13 százalék nevezhető. A fiatalok egyharmada (34 százalék) teljesen absztinens, mivel még nem fogyasztott életében alkoholt. Az illegitim drog fogyasztása a fiatalok 8 százalékánál fordult elő. (Murányi, 2000)

A kortárskapcsolatok befolyásoló hatása jelentős mind a dohányzás, mind az alkohol- és drogfogyasztás vonatkozásában. Különösen erőteljes a kortársak hatása a dohányzás tekintetében. Ha a barátok között van cigarettázó, akkor az ide tartozók fele (50 százalék) rendszeres dohányos, ha nincs, akkor csak 7 százalék. (Murányi, 2000)

Örkényi és munkatársai (2005) az állami gondozásban nevelkedő fiatalok drogfogyasztási szokásait vizsgálta. A kutatók arra a kérdésre keresték a választ, hogy milyen tényezők jelentenek nagyobb rizikót vagy éppen védelmet a drogfogyasztás szempontjából.

A vizsgálatban 15-18 éves állami gondozott fiatalokat kérdeztek meg. A kutatásban összesen 1008 fö vett részt az ország valamennyi megyéjéből.

Önkitöltős kérdőívet alkalmaztak, amely az alábbi kérdéscsoportok köré szerveződött: a gyerekek személyes jellemzői, családi kapcsolatai, iskolai tanulmányai, a gyerekek között előforduló bántalmazás, drog-, és alkoholfogyasztás, a gyerekek élettel való elégedettsége, az önminősített egészség megítélése, valamint a gyermekjogokkal kapcsolatos kérdések. A kutatás eszközeként használták még az alábbiakat: CBCL (Child Behavior Checklist) Deviancia skálája, a pszichológiai Immunrendszer kérdőív rövidített változata, gyermek depresszió kérdőív, Rosenberg önértékelés skála, az élettel való elégedettség mérésére a 11 fokú Cantrill létra. Ezek a kutatások is megállapították, hogy az állami gondozott fiatalok kedvezőtlenebb helyzetben vannak, veszélyeztetettebbek, mint a családban élő társaik. Nagyobb arányban fordult elö körükben a napi dohányzás, a többszöri részegség, a védekezés nélküli szexuális kapcsolat és a különböző drogok kipróbálása. Roszszabb lelki egészség (magasabb depresszió pontszám, magasabb tünetpontszám) és alacsonyabb önértékelés jellemzi őket. (Örkényi és mtsai, 2005)

A drogfogyasztásra vonatkozóan a kutatási eredményeket összevetették az Iskoláskorú gyermekek egészségmagatartása WHO nemzetközi kutatás hazai országos reprezentatív mintájának adataival, és az alábbi következtetésre jutottak: az állami gondozott fiatalok körében az országos átlaghoz képest magasabb a marihuána, a ragasztó, a gyógyszer, a speed és az extasy használat gyakorisága. Közöttük több mint kétszeres a függő dohányosok aránya, magasabb a többszöri részegségről beszámolók, a védekezés nélküli szexuális kapcsolatot létesítők aránya, mint az országos mintában. Az állami gondozott fiatalokra az alacsonyabb önértékelés, magasabb pszichoszomatikus tünet-pontszám és magasabb depresszió- pontszám jellemző (Örkényi és mtsai, 2005). 
Azalkoholt illetően megállapították, hogy a gyerekek 79,8\%-a ivott máréletében, és csupán minden 5. gyerek válaszolta azt, hogy soha nem ivott még. A gyermekotthonban élö fiatalok között nagyobb arányban jellemző az alkohol kipróbálása, mint a lakásotthonban élőknél. A dohányzás tekintetében a kutatók azt találták, hogy a tanulók 61,9 \% -a függőnek számít, vagyis napi szinten dohányzik. A gyermekotthonban élő fiatalok körében a lakásotthonban élőkhöz képest magasabb a napi szinten dohányzók aránya.

A vizsgálat alapján megerősítést nyert a lakásotthonok előnye, szemben a gyermekotthonokkal. A lakásotthonban élő fiatalok ugyanis a jóllétre és a pszichológiai alkalmazkodásra vonatkozó mutatók alapján kedvezőbb helyzetben vannak. Jobbnak ítélik a bánásmódot, és jobb kapcsolatról számoltak be nevelőtanárukkal. Ennek alapján fontos a lakásotthoni hálózat bővítése, annak érdekében, hogy minél több család nélkül maradt gyermek kerülhessen az intimitást és a családi környezetet jobban megvalósító lakásotthoni elhelyezésbe. (Örkényi és mtsai, 2005)

Agyermekvédelmigondoskodásbanélőfiatalokalkohol-,drog-ésdohányzásiszokásairavonatkozóanvégzettkérdőíves vizsgálatotElekes-Paksi(2005).10-18évesfiatalokatkérdeztekmeg, akikintézményekbenésnevelöszülöknélkerültekelhelyezésre. A vizsgálatban 80 gyermekotthon és összesen 993 fö vett részt. A kutatásban a 2003. évi ESPAD kutatás kérdőívét használták.

Akutatásszerintamegkérdezettektöbbségetanul,60,5\%-ukáltalánosiskolábajár. A gyerekek családi hátterére jellemző, hogy a legtöbb probléma a gyermekotthonban élők családjában található. Az országos átlaghoz képest körükben magas a börtönbüntetés, az öngyilkossági kísérlet, a nyugtatók, altatók szedése.

A gyermekotthonban élő fiatalok 37,8\%-a kipróbált már eddigi élete során valamilyen visszaélésre alkalmas tiltott vagy legális szert. Többségük, a megkérdezettek 32,7\%-a biztosan drogfogyasztási céllal használt valamilyen tiltott drogot. Gyógyszer és alkohol kombinált változatával minden ötödik intézetben élő gyerek próbálkozott. A 2003-as ESPAD vizsgálat 16 éves korosztályával összehasonlítva a gyermekotthonban élő fiatalok érintettsége jóval meghaladja a magyarországi normálpopulációét. Míg a hazai 16 évesek között átlagosan minden 6. (16,2\%) próbálkozott eddigi élete során valamilyen tiltott droggal, addig a gyermekotthonban élő azonos korú fiatalok között a kipróbálók aránya 30,8\%. (Elekes-Paksi, 2005)

Örkényiék (2005) kutatásához hasonló eredményre jutott Elekes és Paksi (2005), amikor megállapították, hogy a drogok közül a gyermekotthonban élők leginkább a marihuánát fogyasztják. Körükben jóval korábban jelenik meg reális veszélyként a droghasználat. A 16 éves átlagpopulációban 14-15 éves korban történik a kipróbálás, a gyermekotthonban élők már 14 éves kor előtt túl voltak az első kipróbáláson.

A gyermekotthonban élők közül a szakközépiskolába járók a legérintettebbek a drog szempontjából. 
Az alkoholfogyasztási szokásokat felmérve a kutatók azt találták, hogy a megkérdezettek 56,4\%-a fogyasztott már alkoholt életében. Míg a gyermekotthonban élők alkoholfogyasztása mennyiségben és gyakoriságban is elmarad a 16 éves népesség fogyasztásától, addig a lerészegedés és a nagyivás mutatói meghaladják az átlag populációra jellemző mutatókat. A gyermekvédelmi gondoskodásban élőknél az életkor előrehaladtával az alkoholfogyasztás legtöbb mutatója nő. A szülők iskolai végzettsége, a család szerkezet, a szülőkhöz való viszony befolyásolja a fiatalok alkoholfogyasztási szokásait. A gyermekvédelmi intézményekben élőknél azonban azt találták, hogy nem a család, hanem elsősorban a baráti kapcsolatok alakítják a fogyasztási szokásokat. (Elekes-Paksi, 2005)

A dohányzást a fiatalok 61,7 \%- a legalább egyszer már kipróbálta. Több mint egyharmaduk napi rendszerességgel dohányzik. A dohányzás a gyermekotthonban élőknél magasabb arányú, kétszerese az országos átlagnak. Az életévek számának gyarapodásával párhuzamosan nő a napi hat vagy több cigarettát elszívók aránya. (Elekes-Paksi, 2005)

A kutatási eredmények alapján megállapítható, hogy a gyermekotthonokban élő fiatalok nagyobb veszélyeztetettségnek vannak kitéve a droghasználat, a dohányzás és az alkoholfogyasztás szélsőséges formáira utaló lerészegedés és nagyivás tekintetében. (Elekes-Paksi, 2005, Örkényi és mtsai, 2005)

\subsection{Az intézményekben élő cigány gyerekek}

A gyermekvédelmi gondoskodásba került gyermekek helyzetére vonatkozóan 2005-ben végzett kutatást Neményi - Messing (2007). Azt vizsgálták, hogy milyen okok állnak a gyermekvédelmi gondoskodásba helyezés mögött, vannak-e regionális, települési, illetve a családok szociális és etnikai háttere alapján tapasztalható különbségek az intézménybe kerüléskor, tekintettel vannak-e az elhelyezés során a gyermek speciális és különleges szükségleteire, illetve milyen akadályok állnak a megfelelő ellátás előtt, befolyásolja-e, és ha igen, milyen módon a gyermekvédelmi gondoskodásba kerülés a gyermek iskolai pályafutását, további esélyeit.

A kérdőívet a nevelőszülői és a gyámi tanácsadók töltötték ki a rendelkezésre álló iratanyagok alapján. A kutatásba három korcsoportot vontak be, a 0-3 éves, a 6-7 éves korosztályt és a serdülőkorúakat. Összesen 1866 gyermekre vonatkozóan gyüjtöttek adatokat. Az a tény, hogy a kérdőívek kizárólag a szakszolgálatok munkatársai számára rendelkezésre álló dokumentumok alapján kerültek kitöltésre, jelentősen korlátozta a kutatás mozgásterét. Csak olyan kérdéseket, tehettek fel, amelyeket a gyermekröl elvileg rendelkezésre álló dokumentáció eredetileg is tartalmazott. Másrészt pedig szembesülniük kellett azzal a -mint kiderült, nagyon gyakori - problémával, hogy a gyermekek dokumentációja hiányos. (Neményi-Messing, 2007) 
A kutatást összefoglalva megállapítható, hogy a roma kisebbséghez tartozás nagymértékben kihat a gyermekvédelmi gondoskodásba kerülés valószínüségére. Országos szinten is jelentős mértékü, több mint két és félszeres egy roma gyermek bekerülési esélye lakossági arányaihoz képest, de még kirívóbb az esélykülönbség bizonyos megyék esetében. A lakosságon belüli magas romaarány magával vonja, hogy a gyermekvédelmi szakellátás hatókörébe is rendkívül magas számban -s az országos átlaghoz képest kimagasló arányban - kerülnek roma gyermekek (Borsod- Abaúj -Zemplén, Nógrád vagy Szabolcs-Szatmár-Bereg megyében a gyermekkorú népesség negyedét meghaladó vagy megközelítő roma gyermekarányszámokat, és ebből következően a gyermekvédelmi gondoskodásba akár 73 \%-os roma előfordulási arányt is találhatunk). Mégis a roma gyerekek bekerülésének esélye éppen azokban a megyékben a legmagasabb, ahol a romák lakossági aránya nem éri el az országos átlagot. (Neményi-Messing, 2007)

A gyermekvédelmi szakellátásba került gyermekekre vonatkozóan a szerzők megállapítják, hogy az ország gyermek lakosságának megoszlásával összevetve az látható, hogy a községekben élő gyerekek valamelyest veszélyeztetettebbek. Míg az országos arányuk 36\% körül van (korcsoportonként néhány százalékot tér el), addig a gyermekvédelmi gondoskodásba a kistelepülésről bekerültek aránya $40-45 \%$. Ez feltehetően azzal magyarázható, hogy a községekben súlyosabb megélhetési és szociális problémákkal terheltek a családok, és ezekre gyakran más olyan veszélyeztetettségi ok rakódik (pl. alkoholizmus, pszichés betegségek), amelyek végül a gyermek családból való kiemeléséhez vezetnek. (Neményi-Messing, 2007)

A bekerülés okait vizsgálva a következő megállapítást tették a vizsgált mintára vonatkozóan: a legnépesebb csoportot azok a gyermekek alkották, akiket szüleik elhanyagoltak, a család rossz szociális körülmények között élt, a szülők szenvedélybetegek, illetve a gyerekeket a szülők elhagyták. 624 gyermeket soroltak ide. A második csoportba azok a gyerekek kerültek, akik rossz szociális körülmények között élnek, és ebből fakadóan a szülők elhanyagolták őket. Ide 425 gyermeket soroltak. 320 gyermeket érintett a szülők betegsége vagy halála. 309 gyermek esetében saját deviáns viselkedése miatt került sor a kiemelésre. Az utolsó csoportot azok a gyermekek alkották, akiket szüleik bántalmaztak, esetleg szexuálisan zaklattak. 190 gyermeket soroltak ide a kutatók. A szakellátásba került gyermekek elhelyezésére vonatkozóan a következőket állapították meg: A gyermekek elhelyezésekor tehát úgy tünik, hogy - a gyermekvédelmi törvény céljaival ellentétbennem a gyermek legfőbb szükséglete és érdeke az egyetlen irányadó, meghatározó szempont, hanem a döntést a meglevő struktúra és intézményrendszer adottságai, és gazdasági megfontolások is befolyásolják.

Az elhelyezés körülményeit vizsgálva a kutatók azt találták, hogy a mintába került gyermekek felét gyermekotthonban helyzeték el. A kamaszokra különösen igaz ez, hiszen mindössze 14\%-uk kerül nevelőszülőkhöz. Az etnikai háttér szem- 
pontjából végzett összehasonlítás során megállapították, hogy a romának tartott gyerekek jelentősen nagyobb arányban kerülnek gyermekotthonba, mint nem roma társaik. A csecsemők között az ö 53\%-os gyermekotthoni elhelyezésükkel szemben a nem romák 40\%-os aránya áll, hasonlóan nagy a különbség a serdülők esetében (58\% szemben a 46\%-kal), és ugyan kisebb mértékben, de az iskolakezdők között is túlreprezentáltak a roma gyerekek a nem romákhoz viszonyítva. (35 illetve 30\% ebben az ellátási formában.) Ehhez képest pedig minden korcsoport esetében azt tapasztaltuk, hogy a nem roma gyerekek nagyobb hányada kerül családszerü ellátásba, illetve kamaszok esetében a feltehetően nagyobb önállóságot és az életre való felkészítés szempontjából elfogadhatóbb életformát nyújtó lakásotthoni elhelyezésbe is. (Neményi-Messing, 2007)

Az Európai Unió támogatásával az Európai Roma Jogok Központja (ERRC) szervezett kutatást, Havas-Herczog-Neményi (2007) vezette. Azt vizsgálták, hogy felülreprezentáltak-e a roma gyerekek a gyermekvédelmi szakellátásban, hogyan valósul meg a roma gyermekek örökbefogadása, valamint azt is kutatták, hogy milyen okok miatt aránytalanul magas a szakellátásban élő gyermekek értelmi fogyatékossá nyilvánítása. Módszerként a fókuszcsoportos interjút választották. Magyarország 7 régiójában egy-egy fókuszcsoportos interjú készült, amibe minden érintett szakterület képviselőjét bevonták. Összesen 68 szakember vett részt a fókuszcsoportos beszélgetéseken. Budapesten és Pécsett egy-egy szülő és gyermekcsoporttal is készítettek fókuszcsoportos interjút, összesen 4 alkalommal. A szülőktől és a gyerekektől is megkérdezték, hogy hogyan látják az intézménybe való bekerülésüket. A gyermekcsoportban 14 és 21 év közötti fiatalokat kérdeztek meg, akik között voltak roma és nem roma gyerekek is.

A kutatók megállapították, hogy a roma gyermekek nagymértékben felülreprezentáltak a magyar gyermekvédelmi szakellátási rendszerben. Az ERRC által meglátogatott szakellátási intézményekben a mintába került gyermekek 40 százaléka volt roma és 18 százaléka félig roma származású: együttesen 58 százalékuk. Reális becslések szerint a magyar gyermeknépességnek mindössze 13 százalékát teszik ki a roma gyermekek. Felülreprezentáltságuk a gyermekvédelmi szakellátásban nagyrészt a romák elleni közvetett diszkriminációval magyarázható, azáltal, hogy a gyermekvédelmi törvény elöírásainak alkalmazása, illetve maga a gyermekvédelmi rendszer müködése aránytalanul nagymértékben érinti a roma népességet. A kutatás szerint a kiemelések oka gyakran az anyagi okra vezethetó vissza, a roma gyermekeket gyakrabban emelik ki emiatt, mint nem roma társaikat. A roma gyermekeket nagyobb valószínüséggel nyilvánítják értelmi fogyatékossá vagy sajátos nevelési igényüvé, mint nem roma társaikat. (Fenntartott érdektelenség, 2007)

A roma gyerekek gyermekvédelemben tapasztalható esélyeit kutatta Herczog és Neményi (2007). Fókuszcsoportos beszélgetést folytattak az ország 7 régiójában, 67 szakember részvételével. A kutatókat elsősorban a roma gyerekek helyzete érdekelte a gyermekvédelem rendszerén belül. Vizsgálták az örökbefogadás, a 
szakellátásba való bekerülés okait, és a szakellátásban a fogyatékossá minősítés kérdéskörét is.

Az intézménybe való bekerülés okát nem a gyermekvédelmi rendszer müködésével összefüggő okokkal magyarázták a szakemberek. Ilyennek tekinthető az a vélemény, miszerint nem a gyermek származása, hanem a veszélyeztetettség mértéke befolyásolja, hogy a gyermek szakellátásba kerül-e. Ennek alátámasztására leggyakrabban a romák általános rossz szociális körülményeit, a családok magasabb gyerekszámát említették, de azt az állításukat is megfogalmazták, hogy az átmeneti gondozás feltételei kevésbé adottak roma családok esetében, mint nem roma családoknál. Problémának látták, hogy a veszélyeztető roma családokat környezetük nem tolerálja, szerintük a többségi társadalom romákkal szembeni alacsony toleranciaszintje okolható esetenként a védelembe vételéért. (HerczogNeményi, 2007)

A gyermekvédelmi szakemberek hatókörén kívüli okként hangzott el az is, miszerint a romák felülreprezentáltságának magyarázata az, hogy a romák gyakori deviáns magatartása okozza gyermekeik nagyobb arányú bekerülését. Devianciaként említették az iskolakerülést, a fiatalkorúak körében a gyakori bünelkövetést, a megélhetési bünözés különböző formáit, amelybe a résztvevők szerint a kiskorú gyermekeket is bevonják szüleik. (Herczog-Neményi 2007)

\subsection{Nemzetközi kutatások}

A különböző országok gyermekvédelmi rendszerére vonatkozóan Madge (1994) végzett európai összehasonlító vizsgálatot. Az Európai Közösség 12 országában (Belgium, Dánia, Franciaország, Németország, Görögország, Írország, Olaszország, Luxemburg, Hollandia, Portugália, Spanyolország, Egyesült Királyság) és Svédországban vizsgálta többek között a család nélkül maradt gyerekek elhelyezésének lehetőségeit, miközben bemutatta az adott országok gazdasági-társadalmidemográfiai jellemzőit is.

Az egyes országokban széleskörü változtatásokra került sor a gyermekek életkörülményeiben. A hagyományos intézményekben való elhelyezés kedvezőtlen hatásainak a felismerése arra motiválta az országokat, hogy átalakítsák az intézményrendszert, valamint előtérbe helyezzék a gyereket nevelő családok segítését. Az európai országokban visszaszorulóban van a gyermekotthoni elhelyezés, helyette a kisebb léptékü lakásotthonokat és a nevelőszülői elhelyezést preferálják. Valamennyi országban csökkent a gyermekotthoni férőhelyek száma, és ezzel párhuzamosan nőtt a nevelőszülői elhelyezés aránya. Görögország helyzete kivételes abból a szempontból, hogy itt a többi országhoz képest lassabban fejlődött a nevelőszülői elhelyezés lehetősége. (Madge, 1994) 
Az intézmények átalakítását több tényező is befolyásolta a vizsgált országokban. Egyrészt jobban odafigyelnek a gyermekek jogaira, másrészt gazdasági szempontból az intézményes elhelyezés drágább, mint a többi elhelyezési forma, harmadrészt a közvélemény számos elöítéletet táplál az intézményben felnőtt gyerekekkel, fiatalokkal szemben. Mára a nevelőotthonok kisebbek és kevésbé „intézményes” jellegüek. Dániában mindig is alacsonyabb volt az egy intézményben elhelyezett gyerekek létszáma, mint a többi országban. A ' 70 -es években legfeljebb 50 föt, ma pedig 10-12 főt helyeznek el egy intézményben. Belgiumban a gyermekotthonokon belül kisebb részlegek kialakítására tettek kísérletet, ahol legfeljebb tíz gyerek elhelyezésére nyílt lehetőség. A többi országban is megvalósulni látszik ez a törekvés, bár több országban, így Portugáliában, Spanyolországban, Olaszországban is müködtek még nagy létszámú otthonok a kutatás idején. (Madge, 1994)

Az otthonok között több országban múködnek rövid elhelyezést biztosító otthonok. Belgiumban például megfigyelöközpontokat hoztak létre, ahol rövid ideig, legfeljebb 3 hónapig kapnak ellátást a fiatalok. Luxemburgban pedig addig biztosítanak ellátást, amíg intenzíven segítik a családot, utána visszakerülnek a családba a gyerekek. A bentlakásos iskolák speciális szerepet töltenek be a gyermekek védelmében. Belgiumban, Dániában, Franciaországban és az Egyesült Királyságban használják leggyakrabban ezt a formát a gyerekek védelmére. (Madge, 1994)

Több nemzetközi kutatás is foglalkozik az intézményben élő fiatalok mentális állapotával, drog-, alkoholfogyasztási szokásaival. Angliában, Walesban és Skóciában vizsgálta a gyerekek mentális, érzelmi zavarait, szerfogyasztási szokásait Meltzer és mtársai (2004). A kutatásban 877 fö 5-17 éves gyerekkel végeztek kérdőíves vizsgálatot.

A kutatás eredménye szerint a megkérdezett gyerekek $45 \%$ - a szenved mentális zavarban, súlyos magatartási zavarban 38 \%-uk, szorongásos depresszióban 16 \%-uk és hiperaktív $10 \%$-uk. A dohányzási szokásokra vonatkozóan megállapítható, hogy a megkérdezettek 44\%-a a vizsgálat idején is dohányzott, $27 \%$ mondta azt, hogy még soha nem próbálta. Az alkoholfogyasztás gyakoriságát is vizsgálták. $38 \%$ mondta azt, hogy még soha nem ivott alkoholt, egynegyedük legalább havonta egyszer iszik. A gyerekek 12\%-a mondta azt, hogy tíz éves korában vagy korábban kezdett inni. A drogok közül legtöbben a cannabist használták már életükben, 39\%-uk. Ezeknek a fiataloknak a fele az elmúlt hónapban is használt drogot.

A cannabis után az extasy volt a leggyakrabban használt drog. (Meltzer és mtsai, 2004)

A gyerekek iskolai tanulmányaira vonatkozóan megállapították, hogy a matematika, írás, olvasás elsajátítása sok nehézséget okoz. A gyerekek felének van nehézsége legalább az egyik területen.

A gyerekek közül 59\%-nak van 1 éves elmaradása az iskolai tanulmányok terén az életkorához képest. 19\%-uk 3 vagy több évvel is elmaradt az életkorához viszonyítva. (Meltzer és mtsai, 2004). 
Hasonló eredményre jutott Ford és mtsai is (2007), akik 1453 fó, az 5-17 éves korosztályba tartozó, intézményben élő gyereket vizsgáltak kérdőíves módszerrel, valamint családban élő deprivált és nem deprivált gyerekeket kérdeztek meg, Angliában. A kapott eredményeket összehasonlítva megállapítható, hogy az intézményben élők körében nagyobb arányú a pszichés-, idegrendszeri problémákkal, és a tanulási nehézséggel küzdő gyerekek aránya, mint a nem intézményben élő gyerekek körében. (Ford és mtsai, 2007)

A kábítószer fogyasztást kutatta az intézményben élök körében Thiersch és mtsai (1998). Interjút készített 42 fiatallal, valamint az iratanyagaikat is elemezte. A megkérdezettek közül 25-en már az intézménybe kerülés elött is drogfogyasztók voltak, 17 fönél az ellátás alatt alakult ki ez a probléma. A fiatalok közül legtöbben 15-18 éves korukban kerültek az intézménybe (24 fö). A szülök körében kevéssé fordult elő a drogfogyasztás, mindössze 2 fó esetében. Jellemző a fiatalokra a magatartászavar, gyakran küzdenek tanulási nehézségekkel, koncentrációs problémákkal. Az iskolakerülés a megkérdezettek felénél jelentett problémát. További sajátosság a fiatalok és szüleik között meglévő kapcsolati zavar (17 fö), amit gyakran követ agresszív magatartás. (Thiersch és mtsai, 1998)

Schmid és mtsai (2006) kutatásukban 689 német serdülőt kérdeztek meg CBCL (Child Behavior Checklist) Deviancia skála alkalmazásával. A megkérdezettek a 4-18 éves korosztályba tartoztak és 20 különböző intézményben éltek BadenWüttenbergben. A csoportokban 8,4 fö került elhelyezésre. A vizsgálat szerint az intézményben élő gyerekek közül a legtöbben magatartászavarral küzdenek (26\%), ez a probléma a hasonló korú átlagnépesség $6 \%$-át érinti. Hiperaktív $24 \%$-uk, míg az átlagnépességen belül ez az arány 3-6 \%-os. Az alkohol- és drogfogyasztás az intézményben élők 8,8 \%-át érinti, a hasonló korúak között ez az arány 5\%-al van jelen. További problémaként van jelen a depresszió (10,4\%) és az ágybavizelés (6\%). Az intézményekben élő gyerekek körében nagy kockázata van a mentális betegségek kialakulásának, ami a gyerekek iskolai teljesítményére is hatással van. (Schmid és mtsai, 2006)

$\mathrm{Az}$ intézményben élö gyerekek életkörülményeit, elégedettségét vizsgálta Petermann (1988). 14-18 évesekkel készített interjút, 16 lánnyal és 9 fiúval. A megkérdezettek 1-12 éve voltak az otthon lakói. A tárgyi feltételekkel a fiatalok fele elégedett volt, másik fele hiányolta az egyágyas elhelyezés lehetőségét. A tanuláshoz megfelelőnek találták a feltételeket és a tanuláshoz nyújtott segítséggel is elégedettek voltak.

Kevesellték a közös programok, csoportfoglalkozások számát. Többségüknek a szabályok betartása nem okoz nehézséget. A nevelőkkel való elégedettségre vonatkozóan azt találták, hogy a fiatalok többsége (21 fö) negatív véleményt fogalmazott meg a nevelőkről. Mindenki más-más okban jelölte meg az elégedetlenségét. „Az ember nem bízhat meg benne”, -,,mindent mindenkinél jobban tud”- típusú válaszok születtek. Az ideális nevelöről úgy nyilatkoztak, hogy vannak apai, anyai 
érzései. „Olyan legyen, akinél a munka nem rutin”. Elsősorban szülői érzéseket, a szülők pótlását várják el a nevelőktől. A fiatalok kétharmada úgy nyilatkozott, hogy mióta külön él a szüleitöl, jobb lett a velük való kapcsolata. Az otthonban töltött időt a fiatalok többsége úgy értékelte, hogy pozitív hatással volt a személyiségfejlödésére, önbizalma fejlődött, iskolai tanulmányai javultak. (Petermann, 1988)

Az előbbiekben tehát bemutattuk az intézményekben élő gyerekek körében végzett kutatásokat. Elsősorban azokra a dimenziókra fókuszáltunk, amelyek befolyásolják a gyerekek életkörülményeit. A kutatások többsége a lakásotthoni elhelyezés előnyeire mutatott rá. Megállapíthatjuk, hogy a gyermekvédelmi intézmények átalakításával létrejött lakásotthonok aktívabb munkatevékenységre, nagyobb fokú önállóságra adnak lehetőséget a gyerekek számára. (Madge, 1994; Arató-Csizmadia-Szabó 2002; Örkényi és mtsai, 2005 valamint Zsámbéki, 2004). A lakásotthonokban élő gyerekek elégedettek az elhelyezési körülményeikkel és a velük való bánásmóddal, továbbá gazdag társas kapcsolatrendszerrel rendelkeznek. A szabadidő eltöltésében elsősorban a tévénézés, a számítógépes játékok kapnak teret. Kevéssé jellemzi az intézményekben élő fiatalokat a kulturális programokon való részvétel.

Az iskolázottság tekintetében valamennyi kutatás felveti a gyenge tanulmányi eredmény, a túlkorosság, a lemorzsolódás tényét a fiatalok körében, valamint az ezekhez kapcsolódó pszichés problémákat is. ( Hanák, 1985; Veres-Brezovszky, 1990; Meltzer és mtsai, 2003; Ford, 2007)

A droghasználat, a dohányzás és az alkoholfogyasztás szempontjából az intézményben élő fiatalok veszélyeztetettebbek a kutatások szerint. Az Örkényi és munkatársai (2005), valamint az Elekes-Paksi (2005) által végzett kutatás további jelentősége, hogy országos kutatásban először foglalkoztak a drogfogyasztás és a gyerekek elhelyezési körülményeinek összefüggésével, valamint feltárták az intézményekben élők drogfogyasztási szokásait. A kutatások alapján megállapítható, hogy az intézményben élő gyermekek és fiatalok veszélyeztetettek, a magas kockázati csoportokba sorolhatók a mentális zavarok, valamint a drog-, és alkoholfogyasztás szempontjából. (Meltzer és mtsai, 2003, Ford és mtsai 2007, Schmid és mtsai, 2006) Új témaként jelent meg a roa gyermekek helyzetét feltáró kutatások sora. A korábbi vizsgálatokban legfeljebb utaltak a kutatók az intézményekben elhelyezett roma gyerekek nagy számára. Igazán központi kérdéssé csak az elmúlt 2-3 évben vált a roma gyerekek helyzete a gyermekvédelem rendszerében. 


\section{A HAJDÚ-BIHAR MEGYEI GYERMEKOTTHONOKBAN, LAKÁSOTTHONOKBAN ÉLŐ GYEREKEK ÉLETKÖRÜLMÉNYEI}

A következő fejezetben Hajdú-Bihar megyében, a gyermekotthonokban, lakásotthonokban élő gyerekek körében végzett kérdőíves felmérés eredményei mellett a kutatás célját és módszertanát tekintjük át.

\subsubsection{A kutatás célja, háttere}

Jelen kutatás célja a Hajdú-Bihar megyei gyermekvédelmi intézményekben élő gyerekek vizsgálata a következő szempont alapján:

A gyermekek/fiatalok életkörülményei, a megváltozott intézményi környezet hatása a benne élő gyerekekre

Arra a kérdésre kerestük a választ, hogy a megváltozott intézményi körülmények hogyan befolyásolják a lakásotthonban, gyermekotthonban elhelyezett fiatalok életkörülményeit. Az összehasonlító vizsgálat keretében feltártuk, hogy milyen különbségek vannak a hagyományos gyermekotthonban és a lakásotthonban elhelyezett gyerekek életkörülményei között. Vizsgáltuk a családi/rokoni kapcsolatokat, a társas kapcsolatrendszert, a szabadidős szokásokat, az iskolai tanulmányokat, az alkohol, a drog, a dohányzás kipróbálását, használatát, az intézményi szolgáltatásokkal való elégedettséget, valamint a jövőképet. Ezeket azért tartottuk fontosnak, mivel nemcsak a fiatalok jelenlegi életkörülményeit befolyásolják jelentősen, hanem az intézményből való kikerülés után a társadalomba való beilleszkedési esélyeiket is. A vizsgálat alapvető célkitüzése tehát az, hogy feltárja a gyermekotthonokban, lakásotthonokban elhelyezett gyerekek, fiatalok életkörülményeinek jellegzetességeit.

A gyermek- és ifjúságvédelem ellátási rendszerének átalakítása azzal az előnynyel jár, hogy a költségek növekedése nélkül teszi lehetővé egy eredményorientált, gyermekcentrikus, családbarát, átlátható, hatékony ellátás megvalósulását.

A meglevő intézményhálózat korszerüsítése, az intézmények kiváltása lakásotthonokkal, nevelőszülőkkel, valamint az egyes otthonokban élő gyerekek kisebb létszáma jelentős színvonal-emelkedést jelent. (Herczog, 1997)

Az intézmények átalakítási folyamatának ki kell terjednie a gyermekotthonok telepítésére, elhelyezési körülményeire, szervezeti felépítésére, irányítására, szakmai programjára, müködési módjára, a munkatársak felkészültségére, és az 
intézmények együttmüködésére, kapcsolatrendszerének alakulására is. (Domszky, 1999)

\subsubsection{A kutatás módszertana}

Az alkalmazott módszerek a következők: kérdőíves vizsgálat, amelyet a gyermekotthonokban, lakásotthonokban élő 13-25 éves fiatalokkal vettünk fel, összesen 130 fővel. Cseh-Szombathy és Ferge (1968) tipizálása szerint a kutatás felderítő célú, mivel eddig kevésbé ismert területen tár fel új ismereteket, problémákat.
A kutatásba bevont intézmények köre:
Arany János Gyermekotthon, Berettyóújfalu
Debreceni és Nyírségi Lakásotthonok, Debrecen
DMJV Gyermekvédelmi Intézménye, Debrecen
Gyermekotthon és Hasznos Idő Központ, Komádi
Hajdúsági Lakásotthonok, Hajdúnánás
Reménysugár Gyermekotthon, Debrecen

A kérdőíveket lakásotthonokban és gyermekotthonban készítettük. Nem kerültek be a kutatásba a speciális, a különleges gyermekotthonok, illetve a javító-nevelö intézetek. Ezek a gyermekvédelem rendszeréhez tartoznak, a megyében is megtalálhatók, de az ellátottak köre, a funkcióik különbözősége miatt jelentősen eltérnek a lakásotthonoktól. Ezért ez önálló kutatás tárgyát képezheti a későbbiekben.

A kérdöív kérdései az alábbi kérdéscsoportokat tartalmazza:

1. demográfiai adatok, családi állapot, intézménybe való bekerülés okai stb.

2. szülök, családi/rokoni kapcsolatok, kapcsolattartás a családdal

3. társas kapcsolatok/barátság

4. szabadidő

5. iskolai tanulmányok/munkavégzés

6. értékek, valláshoz való viszony

7. alkohol, drog, dohányzás kipróbálása, használata

8. intézeti környezetre vonatkozó kérdések, elégedettség

9. jövő

A kérdőíves módszer mellett több érv is szólt. Egyrészt a korábbi kutatások áttekintésekor tapasztaltuk, hogy a kutatók Hanák, (1978), Veres - Brezovszky, (1990), Vidra-Szabó (2000) gyakran alkalmazzák a dokumentumelemzés, az iratanyagok áttekintésének módszerét, de ezzel kapcsolatban megfogalmazzák, hogy sokszor előfordul adathiány a dokumentumok nem megfelelő kezelése, kitöltése 
miatt. Másrészt kutatásmódszertani szempontból a kérdőíves vizsgálat előnye többek között a gazdaságosság, az elérhető nagy adatmennyiség, valamint az összegyüjtött adatok standardizáltsága.

\subsubsection{Hipotézisek}

A gyermekotthonokban, lakásotthonokban élő gyerekek életkörülményeinek öszszehasonlító vizsgálatában a következő előfeltevéseket fogalmazzuk meg:

A gyerekek életkörülményeit befolyásolja, hogy milyen a társas kapcsolatrendszerük. Feltételezzük, hogy a lakásotthonban élő gyerekek gazdagabb társas kapcsolattal rendelkeznek, mint gyermekotthonban élő társaik.

Az általunk vizsgált lakásotthonokban élő fiatalok kevesebben próbálták ki és használták a drogot, az alkoholt, valamint kevesebben dohányoznak, mint gyermekotthonban élő társaik.

A lakásotthonban élő gyerekek közül többen tanulnak gimnáziumban és szakközépiskolában, mint a gyermekotthonban élők.

A lakásotthonokban élő gyerekek elégedettebbek az életkörülményeikkel, a velük való bánásmóddal, és többen meg tudják beszélni a problémáikat a nevelőikkel, mint a gyermekotthonban élő társaik.

Feltételezzük, hogy a lakásotthonban élö fiatalok szabadidejükben több kulturális programban vesznek részt, mint a gyermekotthonban élő társaik.

Feltételezzük, hogy az általunk megkérdezett lakásotthonban élö fiatalok aktívabban, több szabadidős programban vesznek részt, mint gyermekotthonban élő társaik.

\subsubsection{A minta jellemzése}

A minta kiválasztásakor fontos szerepe volt az intézményi háttérnek. A Komádiban hagyományos szervezeti keretek között müködő gyermekotthonból és a Hajdúsági Lakásotthonokból kerültek be a 13-25 éves korú gyerekek/fiatalok a vizsgálatba. Komádiban az intézmény átalakítására még nem került sor. Itt 160 föt helyeztek el a kutatás idején egy hagyományos, régi keretek között müködő, több épületből álló intézményegyüttesben. A Hajdúsági Lakásotthonok országosan is az elsők között alakultak át. A növendékek a lakásotthoni elhelyezéssel kapcsolatban itt rendelkeznek a legnagyobb tapasztalattal. Azért esett a választás erre a két intézményre, mert így lehetőségünk nyílik a két különböző típusú intézményben élők körülményeinek összehasonlítására is. Az általunk kapott adatok elsősorban tendenciákat jeleznek, nem általánosíthatók. 


\subsubsection{A kutatás eszköze}

Az intézményekben valamennyi 13-25 éves elhelyezett fiatalt megkérdeztük. A kérdőív önkitöltős volt. 160 kérdőívet osztottunk ki, 130 érkezett vissza, ebből 123 volt értékelhető. Az adatok feldolgozása SPSS 12.0 programmal történt. A kérdőív összeállításához felhasználtuk Örkényi (2005) és munkatársai Drogfogyasztás az állami gondozott fiatalok körében címủ kutatás néhány kérdését. Ezek a következők: nemzetiségi hovatartozásra, családi kapcsolatokra, kortárskapcsolatok/barátok számára és az intézményi környezetre vonatkozó kérdések.

Fontosnak tartottuk, hogy a kapott eredményeket - ahol van rá mód-, más kutatások adataival is össze tudjuk vetni. Ehhez felhasználtuk Hanák (1978), VidraSzabó (2000) illetve Örkényi (2005) és munkatársai által kapott eredményeket, amit a dolgozat elméleti fejezetében mutattunk be. Felhasználtuk továbbá Murányi (2000) Nevelőotthonban élő fiatalok drogfogyasztása és értéktudata címü kutatását. A szerző kérdőíves vizsgálatot végzett Szabolcs-Szatmár-Bereg megyében, 263 fő állami gondozásban élő fiatalt kérdezett meg drogfogyasztási szokásairól, értékpreferenciáiról. Felhasználtuk még Elekes és Paksi (2005) kutatását, amelyben a gyermekvédelmi gondoskodásban élő, gyermekotthonban lakó, valamint nevelőszülőknél élő fiatalok alkohol-, és egyéb drogfogyasztási szokásainak, az ezzel kapcsolatos értékeinek, attitüdjeinek feltárását, leíró elemzését végezték. A vizsgálatban 80 gyermekotthon és 993 fö vett részt. A fejezetben megjelennek az Ifjúság 2004 kutatás eredményei is. Ezt a kutatást 15-29 éves fiatalok körében végezték, összesen 8000 fövel. Vizsgálták többek között a fiatalok gazdasági aktivitását, szabadidő eltöltési szokásait, iskolázottságát, értékpreferenciáit, kulturális fogyasztását.

\subsection{A kérdő́íves vizsgálat eredményei}

A fejezet következő részében a kérdőíves vizsgálat eredményeit foglaljuk öszsze. Az elemzett változók nemek, etnikum és gondozási hely szerinti megoszlását a következőkben mutatjuk be. Az elemzés során, ahol ez szükségesnek bizonyult, az adatoknak megfelelő statisztikai próbákat alkalmaztunk. Leggyakrabban független t-próbát, egymintás t-próbát és $\chi^{2}$-próbát.

\subsubsection{Demográfiai adatok, családi állapot, intézménybe való bekerülés}

A kérdőíves felmérés első blokkjában a gyerekek szociodemográfiai adatait vizsgáltuk. A kérdések között szerepelt az életkor, az intézménybe való bekerülés ideje, helye, a szülők iskolai végzettsége, a testvérek száma. 
21. táblázat. A minta megoszlása nem és elhelyezési hely szerint

\begin{tabular}{|l|c|c|c|c|c|c|}
\hline \multirow{2}{*}{ Megnevezés } & \multicolumn{2}{|c|}{ Gyermekotthon } & \multicolumn{2}{c|}{ Lakásotthon } & \multicolumn{2}{c|}{ Összesen } \\
\cline { 2 - 7 } & $\mathbf{N}$ & $\mathbf{\%}$ & $\mathbf{N}$ & $\mathbf{\%}$ & $\mathbf{N}$ & $\mathbf{\%}$ \\
\hline Fiú & 41 & 63,6 & 30 & 52,6 & 72 & 58,5 \\
\hline Lány & 24 & 36,4 & 27 & 47,4 & 51 & 41,5 \\
\hline Összesen & 66 & 100 & 57 & 100 & 123 & 100 \\
\hline
\end{tabular}

A 21. táblázat adatai szerint a megkérdezett 123 főből, 66 fő a Komádi Gyermekotthonban, 57 fő a Hajdúnánási Hajdúsági Lakásotthonokban élt. A válaszadók többsége 58,5 \% - a fiú, 41,5 \% - a lány. Az intézményekben - ahogy azt a korábbi kutatások Hanák (1978), Vidra-Szabó (2000) is mutatták -, a fiúk vannak többen. Ez a megállapítás mindkét intézményre igaz, a gyermekotthonban és a lakásotthonban elhelyezettek több mint fele fiú.

A gyerekek átlagéletkora 17 év. A független t-próbával végzett elemzés szerint nincs szignifikáns különbség a gyermekotthonban és a lakásotthonban élők átlagéletkora között.

A gyerekek intézménybe való bekerülésekor az átlagéletkoruk 9 év.

4. ábra. Az intézménybe kerülés életkor szerint

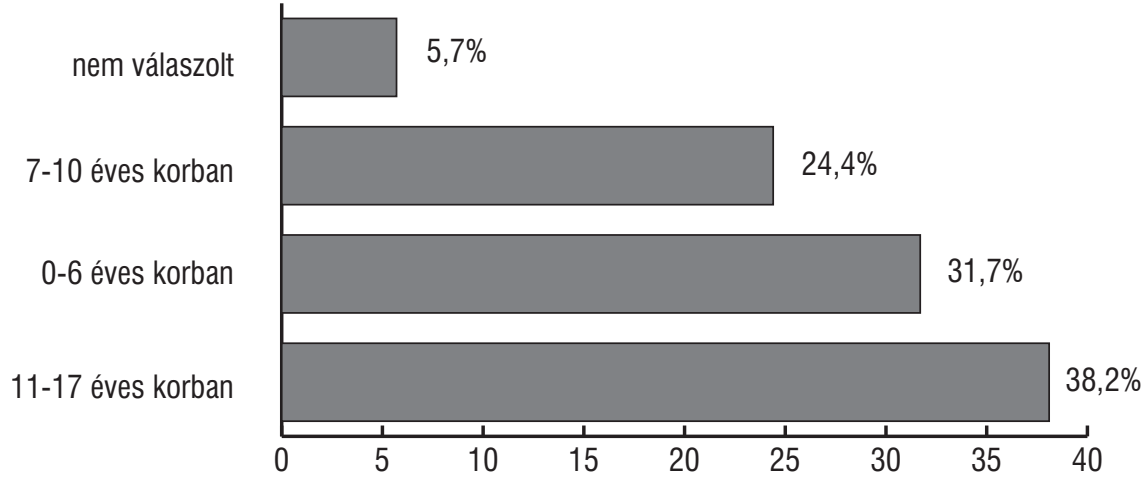

A 4. ábrán látható adatok szerint az intézetbe kerülésre jellemző, hogy a gyerekek 0-6 éves korában, illetve serdülökorukban történik. Az összes gyermek közel kétharmada e két életszakasz valamelyikében vált az ellátórendszer kliensévé. A 0-6 éves korúak nagyarányú intézménybe kerülése több problémát vet fel. Ez az időszak fontos a személyes kötődések kialakulásának szempontjából. Az intézményi elhelyezés ugyanakkor nem tudja biztosítani a gondozó személyének állandóságát. Ez a későbbi fejlődés gátja lehet. Az adatok alapján az is megállapítható, hogy serdülökorban is magas az intézménybe való bekerülés aránya. A kérdőív által kapott 
adatok megerősítik az intézményvezetőkkel készült interjúk állításait, miszerint 15-16-17 évesen is bekerülnek fiatalok az otthonokba. A serdülőkorú fiatalok ellátására az intézmények felkészületlennek érzik magukat.

A vizsgálatban rákérdeztünk a fiatalok nemzetiségi, etnikai hovatartozására. Az alábbi kategóriákból választhattak: román, cigány, szerb, szlovák, német, magyar. A 2001-es népszámlálás adatai szerint a kisebbségek közül az etnikai kisebbséghez tartozó cigányok élnek a legnagyobb arányban, Hajdú-Bihar megyében. Jóval kisebb arányú a román, német, szerb, szlovák és más nemzetiségi kisebbségek jelenléte. A fiatalok 48\%-a cigány etnikumhoz tartozónak vallotta magát, 48\%-uk magyarnak, 5 gyerek nem válaszolt erre a kérdésre. $\chi^{2}$-próba alkalmazásával hasonlítottuk össze a cigány és nem cigány gyerekek arányát az otthonokban. Megállapítható, hogy a nagyobb, még átalakításra váró gyermekotthonban több cigány gyerek él, itt a gyerekek 65,2\%-a romának vallotta magát, 28,8 \%- uk magyarnak. A lakásotthonokban jóval kisebb arányban találtunk cigány növendékeket, mindössze a gyerekek $28,1 \%$ - a vallotta magát cigánynak.

A kapott válaszok összecsengenek a Neményi-Messing (2007) szerzőpáros tapasztalataival, nevezetesen, hogy a romának tartott gyerekek jelentősen nagyobb arányban kerülnek gyermekotthonba, mint nem roma társaik. Vizsgálatuk szerint a nem roma gyerekek nagyobb hányada kerül családszerü ellátásba, illetve kamaszok esetében a feltehetően nagyobb önállóságot és az életre való felkészítés szempontjából elfogadhatóbb életformát nyújtó lakásotthoni elhelyezésbe is.

Az állami gondozásba vétel időpontja a legtöbb esetben megegyezik az adott intézménybe való bekerülés időpontjával. Ebből arra következtethetünk, hogy a gyerekek többsége bekerülése óta nem váltott intézményt.

5. ábra. Az intézménybe való bekerülés elözménye

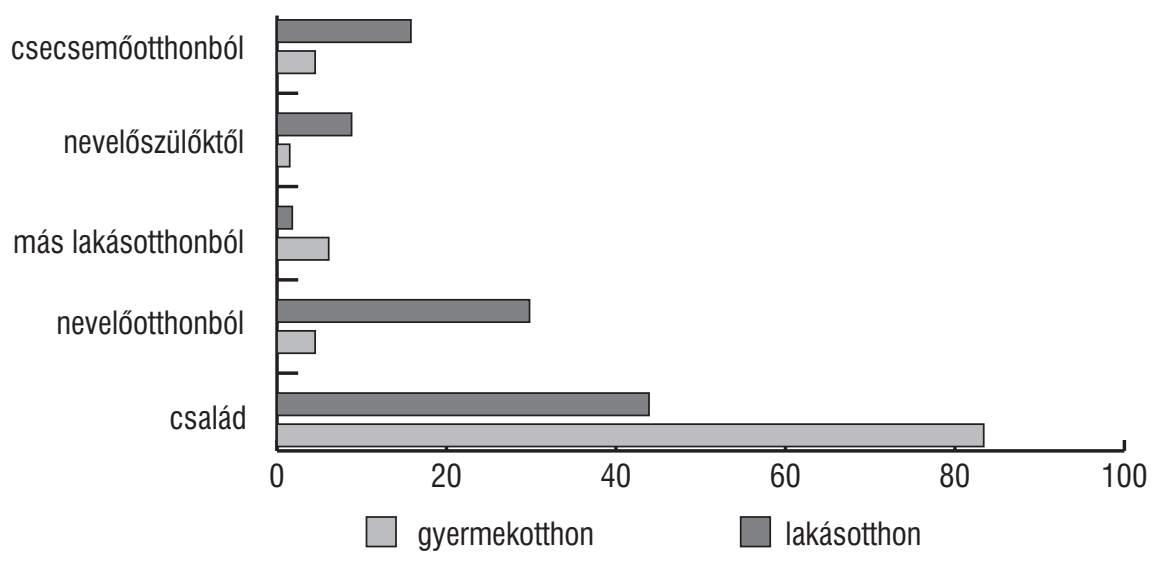


Az 5. ábra adatai alapján megállapítható, hogy a gyerekek mind a két típusú intézménybe elsősorban a családból kerültek be. A nevelőotthonból való bekerülés magas aránya a lakásotthonokba azzal magyarázható, hogy a megkérdezett gyerekek 29,8 \%- a már az intézmény lakója volt a lakásotthoni átalakítás előtt is. A más lakásotthonokból való átkerülés alacsony számú. Ebböl arra következtetünk, hogy a gyerekek többnyire abban az intézményben maradnak, ahova elöször bekerültek. Az intézményvezetőkkel készült interjúk is alátámasztják, hogy elsősorban akkor kerül sor intézményváltásra, ha a gyereknek olyan szolgáltatásra - pl. egészségügyi ellátásra - van szüksége, ami jobban elérhető egy másik településen található intézményben.

Vidra-Szabó (2000) kutatásában arról számolt be, hogy a szülők által hazavitt gyerekek gyakran visszakerültek az otthonokba, de már másik otthonba kerültek, nem az eredeti helyükre. A szerző velünk ellentétben azt tapasztalta, hogy a gyerekotthonban élö gyerekek 40\%-a már több áthelyezést is átélt. Pozitívumnak tartjuk, hogy az általunk vizsgált intézményekben ilyen típusú áthelyezésekre csak ritkán kerül sor. Fontos ugyanis a gyermek biztonságérzete szempontjából, hogy ne kelljen több alkalommal is új környezethez, új emberekhez alkalmazkodnia.

Az intézményben töltött átlagos idő 7, 57 év. A gyermekotthonban élők átlagosan 8, 1 évet, a lakásotthonban élők átlagosan 6,96 évet töltenek gondozásban. A t-próba eredménye szerint ez a különbség nem szignifikáns a két intézmény tekintetében. Az intézményben töltött idő átlagos hossza több szempontból is fontos, jelentősen befolyásolja ugyanis a családba való visszahelyezés lehetóségét. A szakemberek szerint, ha 5 évnél hosszabb időt tölt egy gyerek intézményben, akkor nagyon kevés esélye marad arra, hogy a családjába visszahelyezhető legyen. Ennyi idő alatt a családok átalakulnak, újabb gyerekek születhetnek, új partner jelenik meg. Ez kevéssé teszi valószínűvé a gyerek visszafogadását. Az intézményben töltött idő szempontjából kedvezőtlen a vizsgált intézményekben élő gyerekek helyzete. Ez is oka lehet annak, hogy a nagykorúvá válás után elsősorban az önálló életet vagy az utógondozói ellátást választják a gyerekek, és nem a családba való visszatérést, ahogy azt az adatlapunk adatai is mutatták.

\subsubsection{Szülők, családi/rokoni kapcsolatok, kapcsolattartás a családdal}

A gyerekek intézményben töltött éveire, az intézményből való kikerülés lehetőségeire jelentős hatással van a családi háttér, a családdal való kapcsolat. Hanák (1985), Szikulai (2004) - a dolgozat korábbi fejezetében bemutatott - kutatásában arra a megállapításra jutott, hogy azok a gyerekek, akiknek van kapcsolata a vér szerinti családjukkal, sikeresebben illeszkednek be a társadalomba. A családi kapcsolatok fontosságát igazolja Albert és Dávid (2007), akik szerint Magyarországon a legbizalmasabb kapcsolathálózatokban a barátok száma elenyésző. Míg 1997-ben a fontos beszélgetési hálózatokban megemlített személyek 75 \%-a volt a válaszadó 
családtagja illetve rokona, 1999-ben ugyanez az arány $85 \%$. Azaz az emberek döntő többsége rokonaival, sőt még pontosabban legszükebb családtagjaival, házas-illetve élettársával, szülőjével, gyermekével vagy testvéreivel beszéli meg fontos dolgait. A barátoknak ebben a tekintetben sokkal kisebb a szerepe, a szomszédoké, munkatársaké pedig elenyésző. (Albert - Dávid, 1999). Ezek alapján fontosnak tartottuk az általunk vizsgált gyerekek családi kapcsolatainak a feltárását.

A gyerekek szüleinek többsége él. A megkérdezettek szülei közül az apák 73,2 \%-a él, mindössze a gyerekek 6,5 \%-a nem tud az apjáról. Az anyák 71,5 \%-a él, a gyerekek 5,7 \%-a nem tud az anyáról.

6. ábra. A szülök iskolai végzettsége

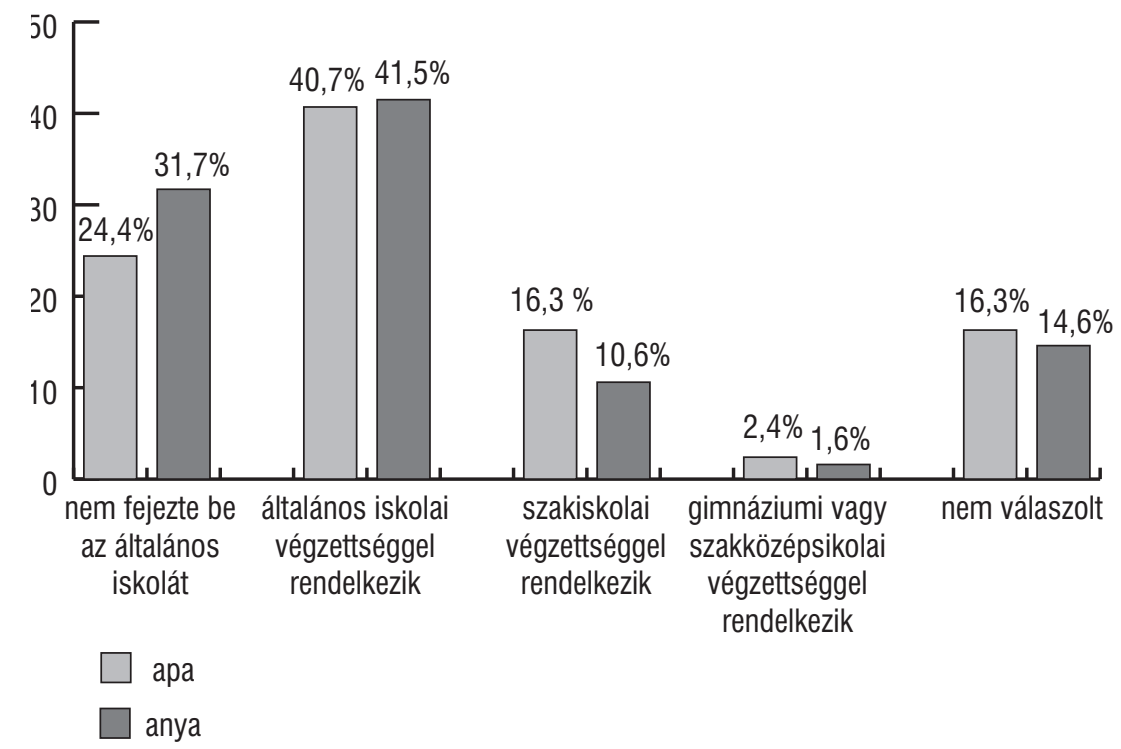

A szülők iskolai végzettségére vonatkozóan (6. ábra) megállapítható, hogy az apák 24,4 \%-a nem fejezte be az általános iskolát, 40,7 \%- uk általános iskolai végzettséggel rendelkezik. Szakiskolai végzettsége 16,3\%-uknak van, gimnáziumba vagy szakközépiskolába mindössze 2,4 \%-uk járt. A nem válaszolók aránya 16,3 \%. Ebből arra következtetünk, hogy ezek a gyerekek nem rendelkeznek információkkal a szüleikre vonatkozóan. Összességében az apák több mint fele $(65,1 \%)$ általános iskolai vagy annál alacsonyabb iskolai végzettséggel rendelkezik.

Az anyák iskolai végzettségére vonatkozóan a következőket találtuk: 31,7 \% nem fejezte be az általános iskolát, 41,5\% általános iskolát végzett. Mindössze $10,6 \%$ szerzett valamilyen szakmát, gimnáziumban 1,6 \%-uk tanult. A nem válaszolók aránya 14,6\%-os volt. 
A 2001-es népszámlálás adatai szerint az észak-alföldi régióban az általános iskolai végzettséggel rendelkezők aránya a felnőttek minden ötéves korcsoportjában $90 \%$ felett van. Legalább a középiskola 12. évfolyamát minden ötéves korcsoportban a felnőttek több, mint $35 \%$-a elvégezte. Összevetve a szülők iskolai végzettségét az észak-alföldi adatokkal, megállapítható, hogy az általunk megkérdezettek szüleinek az iskolai végzettsége lényegesen alatta marad a régióban élő népesség átlagához képest.

Az alacsony iskolai végzettségből fakadóan a szülők foglalkozási adatai sem mutatnak kedvező képet. Az apák egy része alkalmi munkát végez, vagy szakképzettséget nem igénylő munkakörben dolgozik, pl. állatgondozó, tehenész, napszámos stb., más részük munkanélküli, börtönbüntetését tölti. Kisebb hányaduk végez csak szakmunkát.

Az anyák foglalkozási adatai az apákéhoz hasonlóan kedvezőtlenül alakul. Az anyák körében azonban még több a munkanélküli, a háztartásbeli. Egy kisebb hányaduk pedig GYES-en van.

A gyerekek családi kapcsolatainak további jellemzője, hogy a gyerekek többségének $(83,1 \%)$ három vagy több testvére van.

Az adatokat áttekintve megállapítható, hogy nem térnek el a korábbi kutatások eredményeitől Hanák (1978), Vidra-Szabó (2001), Örkényi (2005), Elekes - Paksi (2005). A gyerekek családi körülményeire vonatkozóan mind a négy kutatás úgy találta, hogy a gondozásban élö gyerekek többségének a szülei élnek. A szülők többnyire alacsony iskolai végzettséggel rendelkeznek, keresetük alacsony vagy nem rendelkeznek keresettel. Jellemző, hogy három vagy több gyereket nevelnek egy családban. Gyakori, hogy a szülők elhagyták gyerekeiket, az alapvető szükségletiekről sem gondoskodtak. Így szükségessé vált az intézményi elhelyezésük. Az általunk vizsgált intézményekben élö gyerekek többsége sem árva, hanem valamilyen egyéb ok miatt került intézménybe.

A kutatásunk eredményei alapján kirajzolódik a gyerekek azon csoportja, akiknek körében nagyobb a kockázat az intézménybe való bekerülésre. Ök elsősorban a munkaerőpiacról kiszoruló, alacsony iskolai végzettséggel rendelkező, három vagy több gyereket nevelö, deviáns magatartású szülők gyermekei.

Felmértük a gyerekek és családjuk közötti kapcsolattartást. A gyerekek 88,6 \%- azt válaszolta, hogy tartja a kapcsolatot a családjával. Arra a kérdésre, hogy kivel tartja a kapcsolatot a legnagyobb arányban $(50,6 \%)$ a testvérüket jelölték meg. A szülők közül leginkább $(16,4 \%)$ az anyával tartják a kapcsolatot. Mindkét szülővel a gyerekek 16,4\%-a tart kapcsolatot. A gyermekotthon és a lakásotthon között nem találtunk lényeges különbséget a kapcsolattartásra vonatkozóan. A gyerekek többsége mindkét intézményben kapcsolatot tart a családjával.

A lányok 90,2 \%-a tart kapcsolatot a családjával, míg a fiúk kevesebben, 87,3\%. Mind a fiúk, mind a lányok a testvérüket jelölték meg kapcsolattartó személyként. 
A cigány gyerekek többsége (86,4\%), és a nem cigány gyerekek többsége is $(89,8 \%)$ kapcsolatot tart a családjával. Mindkét csoportban a testvért jelölték meg, akivel leginkább kapcsolatot tartanak.

Az adatok alapján megállapítható, hogy a családdal való kapcsolattartás elsősorban a testvérekkel való kapcsolattartást jelenti, akik gyakran maguk is az intézmény lakói.

Örkényi (2005) és munkatársai hasonló eredményre jutottak. Az általuk megkérdezett gyermek- és lakásotthonban élő gyerekek közel azonos arányban tartják a kapcsolatot a szüleikkel. A családi kapcsolatok közül a gyerekek legnagyobb arányban $(53,3 \%)$ a testvért jelölték meg. Ennek okát abban látják a kutatók, hogy a családból való kiemelés esetében az egyik szempont, hogy a testvérek lehetőleg ugyanabba az otthonba kerüljenek.

Vidra-Szabó (2001) úgy találta, hogy az általa feltárt esetek 1/3-ában semmilyen külső kapcsolata sincs a gyerekeknek. 1/3-nak az anyákkal van szorosabb-lazább kapcsolata. Az apák közül minden tizedik tart kapcsolatot a gyerekkel.

Elekes-Paksi (2005) országos vizsgálatában szintén arra a megállapításra jutott, hogy a leginkább a testvérekkel tartanak kapcsolatot az intézményben élö fiatalok. A szerzők szerint a gyerekek 18 \%- a semmilyen külső kapcsolattal nem rendelkezik. Ugyanakkor azt is megállapították, hogy a gyermekotthonban élők 70\%-a tart a kapcsolatot a szülőkkel havonta többször, sőt heti rendszerességgel találkoznak vér szerinti szüleikkel.

Kutatásunkban Elekestől és Paksitól (2005) eltérően nem találtunk ilyen intenzív kapcsolattartást a gyerekek és a szülők között. Ennek oka lehet többek között az, hogy az általunk megkérdezett gyermekotthonban élö gyerekek átlagosan 8,1 évet töltöttek gondozásban, ami túl hosszú idő lehet az intenzív kapcsolattartáshoz. A szülők egy része, látva, hogy gyermeke jobb körülmények között él, mint a családjában, elfogadja ezt a helyzetet. Különösen igaz ez akkor, ha a szülő saját életkörülményeinek javítása érdekében tett erőfeszítései is kudarcot vallanak.

Ahogy a korábbiakban bemutattuk, az intézmények mindent megtesznek annak érdekében, hogy segítsék a szülők és gyerekeik találkozását, ennek ellenére vannak hiányosságok ezen a területen. A kapcsolattartás fontos, mivel akkor van esély arra, hogy a gyerek visszakerülhessen a családjába, ha müködö kapcsolat van közöttük. A szülőkkel való kapcsolat nemcsak a jelenlegi életkörülményekre van jelentős hatással, hanem a későbbiekre is. A kutatások szerint azok a fiatalok illeszkednek be sikeresebben a társadalomba, akiknek van kapcsolatuk a családjukkal. Adataink alapján megállapítható, hogy az általunk megkérdezett gyermekotthonban élö gyerekek a kapcsolattartás szempontjából rosszabb helyzetben vannak, mint az ország más gyermekotthonaiban élő társaik. 
7. ábra. A problémák megbeszélésének lehetöségei

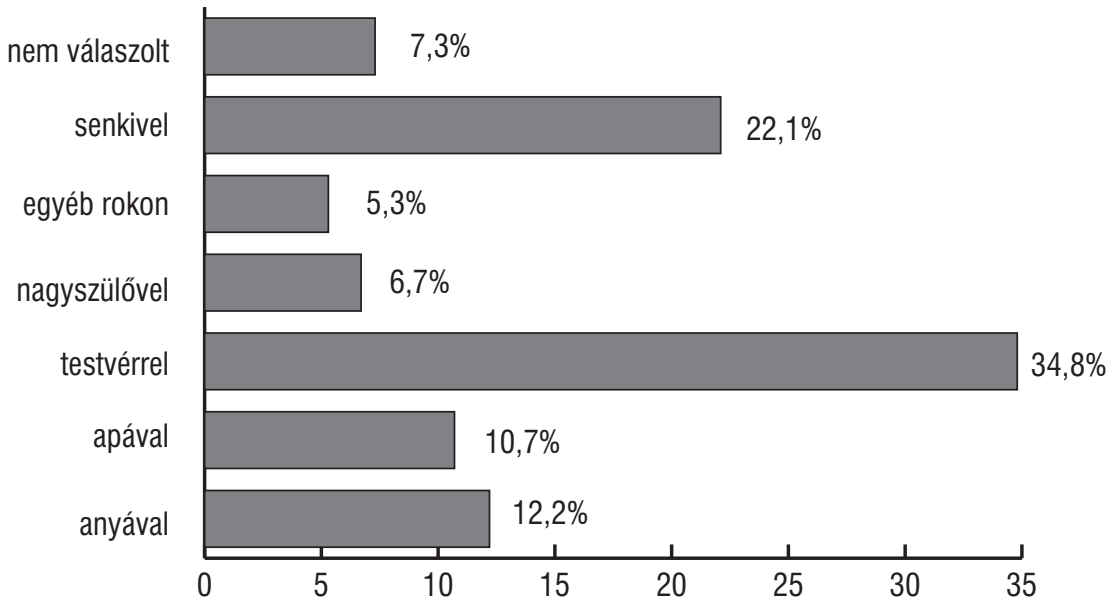

Arra a kérdésre, hogy kivel tudják a problémáikat megbeszélni a családtagok közül, legnagyobb arányban (34,8\%) szintén a testvéreket jelölték meg. (7. ábra) Ez következik abból is, hogy a legtöbben a testvéreikkel tartják a kapcsolatot, akik gyakran maguk is az intézmény lakói. A 7. ábra adatai alapján megállapítható, hogy magas azoknak a válaszadóknak az aránya, akik senkivel nem tudják megbeszélni a problémájukat. A gyerekek 22,1 \%-a válaszolt így. Ezt azért tartjuk problémának, mert ezek a gyerekek alacsony társas támogatottsággal rendelkeznek, ami nehezíti a stresszel való megküzdésüket, a későbbiekben pedig a társadalmi beilleszkedésüket. A nagyszülőkkel mindössze 6,7 \%-uk osztja meg problémáit. Az egyéb rokonokkal való problémamegosztás lehetőségét pedig csak néhányan jelölték meg.

Összehasonlítva a két intézményben kapott válaszokat, megállapítható, hogy a nagy létszámú gyermekotthonban és a lakásotthonban is elsősorban a testvérekkel osztják meg a problémáikat. Különbséget abban találtunk, hogy azoknak az aránya, akik senkivel nem tudják megbeszélni problémáikat, a nagy gyermekotthonban lényegesen magasabb (31,8 \%), mint a lakásotthonokban $(21,1 \%)$. A lakásotthon kedvezőbb adatait azzal magyarázzuk, hogy a lakásotthonban a kisebb létszám, nagyobb intimitás lehetővé teszi, hogy bizalmasabb kapcsolat alakuljon ki akár a nevelőkkel, akár a gyerektársakkal. Mindkét otthonban jellemző, hogy a nagyszülővel vagy más rokonnal csak kevesen tudják megosztani problémáikat, mindössze néhány fó.

A problémamegbeszélés szempontjából lényeges különbséget találtunk a lányok és fiúk között. A fiúk között jóval magasabb, 35,2 \%-os azoknak az aránya, akik senkivel sem tudják megbeszélni a problémáikat, míg a lányoknak csak 13,7 \%-a mondta ugyanezt. Mind a fiúk, mind a lányok a testvérükkel tudják leginkább megbeszélni a problémáikat. 
Albert és Dávid családkutatásában vizsgálta a 15-20 éves fiatalok kapcsolathálózatát, ahol azt találta, hogy a lányok jóval több emberhez fordulhatnak lelki támaszért, mint a fiúk. (Albert-Dávid 2007)

Különbséget találtunk a nem cigány és a cigány gyerekek között abban a tekintetben, hogy azoknak a gyerekeknek az aránya, akik senkivel nem tudják megbeszélni a problémáikat, a nem cigány gyerekeknél magasabb ( 28,8\%), mint a cigány gyerekek körében ( $22 \%$ ). Mindkét csoport leginkább a testvéreivel tudja megbeszélni a problémáit. A nagyszülőkkel a cigány gyerekek 8,5\%-a, a nem cigány gyerekek 5,1\%-a osztja meg a nehézségeit. Egyéb rokonnal a cigány gyerekek 6,8\%-a, a nem cigány gyerekeknek csak 3,4\%-a.

Az adatok alapján megállapítható, hogy a gyerekek jelentős része a problémájával magára marad. A lakásotthonban élők valamivel kedvezőbb helyzetét mutatja az, hogy ott kisebb azoknak a gyerekeknek az aránya, akik senkivel nem tudják megbeszélni a problémáikat, mint a gyermekotthonban. A nagyszülök és az egyéb rokonok mint kapcsolattartó személyek az általunk megkérdezettek között nem jelennek meg jelentős számban. Ebből az látszik, hogy a szülőket nem pótolja más rokon vagy egyéb felnőtt. Hasonló eredményre jutott Elekes - Paksi (2005) is, aki úgy találta, hogy a nagyszülőkkel csak ritkán tartanak kapcsolatot a gyerekek, így a szülők helyébe csak elvétve lépnek a nagyszülők. Ha az édesapjával, az édesanyjával nincs semmilyen kapcsolata, akkor csak ritkán van kapcsolata bármilyen más rokonnal vagy egyéb felnőttel, aki a szülő hiányát pótolja. (Elekes-Paksi, 2005)

Örkényi és munkatársai (2005) kutatásában nem talált különbséget a családtagokkal való problémamegbeszélés minőségében a gyermekotthonban és a lakásotthonban élők között, és a cigány és nem cigány gyerekek között sem.

Kutatásunkban ezzel ellentétben, mind a gyermekotthonban és lakásotthonban élők között, mind a cigány és nem cigány gyerekek között különbséget találtunk a családtagokkal való problémamegbeszélés tekintetében. Azt találtuk, hogy a családdal való kapcsolati hálózat mérete nagyobb a cigány gyerekeknél, nagyobb arányban tudják nagyszüleikkel, illetve más rokonaikkal megbeszélni a problémáikat, mint nem cigány társaik. A cigány gyerekek között kisebb arányban vannak azok, akik senkivel nem tudják a problémáikat megbeszélni, mint nem cigány társaik között. Az országos adatokkal összehasonlítva megállapítható, hogy az általunk megkérdezett cigány gyerekek körében a nagycsalád és a roma közösség inkább képezi a kapcsolati erőforrás alapját, mint az ország más gyermekvédelmi intézményeiben élőknél.

\subsubsection{Társas kapcsolatok/barátság}

A barátaink jelentősen hozzájárulnak boldogságunkhoz és megelégedettségünkhöz, a betegségek iránti sérülékenységünk csökkentéséhez és ahhoz, hogy meg tudjunk birkózni a stresszel. (Albert-Dávid 2007) A társas támogatás különösen 
fontos lehet az intézményekben élő gyerekek körében, mivel, ahogy azt az előző alfejezetben láttuk a családdal való kapcsolatuk kevés támogatást biztosít a számukra. A gyerekek többsége (82,1\%) azt válaszolta, hogy három vagy több barátja van, két barátról 8,9\%-uk, egy barátról 8,1\%-uk tett említést, és mindössze $0,8 \%$ mondta azt, hogy nincs barátja.

Megvizsgáltuk, hogy hogyan alakulnak a baráti kapcsolatok a két különbözö intézménytípusban. Feltételeztük, hogy a lakásotthonokban élö gyerekek több baráttal, gazdagabb társas kapcsolattal rendelkeznek, mint a nagy létszámú gyermekotthonban élő gyerekek. A gyermekotthon lakói közül 75,8 \%-nak három vagy több barátja van, a lakásotthonban élők között ez az arány 89,5\%. Két barátja a nagy otthonban élők között 12,1 \%-nak van, míg a lakásotthonban élőknél 5,3 \%-nak. Egy baráttal a nagy otthonban élő gyerekek közül 10,6 \% rendelkezik a lakásotthon lakói között ez 5,3\%. Egy gyerek mondta azt, hogy nincs barátja, ő gyermekotthonban él. A nemek között nem találtunk lényeges különbséget a barátok számában. Különbséget találtunk a barátok számában a cigány gyerekek javára. $86,4 \%$-uk mondta azt, hogy három vagy több barátja van, míg a nem cigány gyerekeknek csak $78 \%$-a.

A baráti kapcsolatok alakulását segítheti az intézményi környezet is, mivel itt hasonló korú gyerekekkel több alkalmuk van találkozni. Az adatok alapján megállapítható, hogy a gyerekek gazdag társas kapcsolatrendszerrel rendelkeznek. Erre utal a barátokkal való találkozások gyakorisága is. A gyerekek többsége (79,7 \%) hetente 4 vagy több alkalommal találkozik a barátjával. A baráti kapcsolatok elemzésénél fontos megemlíteni, hogy a társas kapcsolatok megerősödése a serdülőkor sajátossága. Ugyanakkor a kutatások szerint az évek és a barátok száma fordítottan arányos: az életkor elöre haladtával lassan, de biztosan csökken a barátok száma, és ezzel párhuzamosan nő a barát nélkül élők aránya. (Albert-Dávid 2007)

Kíváncsiak voltunk arra is, hogy mennyire vállalják fel a gyerekek társaik előtt azt, hogy intézményben élnek. Ezért megkérdeztük, hogy szoktak-e barátokat hívni az otthonba. A gyerekek 56,9 \%-a azt válaszolta, hogy szokott barátokat hívni, és csak 41,5\%-uk mondta azt, hogy nem. Az adatok alapján jól látszik, hogy a gyerekek többsége vállalja, hogy intézményben él, ezt nem szégyelli a barátai előtt.

Összehasonlítva a két intézményben kapott adatokat, a következőket találtuk. Jelentős különbség van a két intézménytípus között abban, hogy szoktak-e az otthonba barátot hívni.

A nagy létszámú otthonban a gyerekek 43,9 \%-a válaszolt igennel, jóval többen, a gyerekek 71,9 \%-a szokta meghívni a barátait a lakásotthonba. Ennek az okát abban látjuk, hogy a lakásotthonban a tárgyi feltételeket tekintve több lehetőség van intim baráti beszélgetésre, mint ott, ahol 12 gyerek van egy szobában. A lányok közül többen, $(68,6 \%)$ hívják az otthonba a barátaikat, mint a fiúk $(47,9$ $\%$ ). A barátaikat a nem cigány gyerekek inkább meghívják az otthonba, mint a cigány társaik. Ennek oka lehet, ahogy azt a későbbiekben látni fogjuk, az, hogy a 
cigány gyerekek eleve kevesebb külső, családban élő baráttal rendelkeznek, mint a nem cigány társaik.

A barátok lakóhelyére vonatkozóan azt találtuk, hogy a gyerekek 56,7 \%-nak a barátja családban él. A lakásotthonokban él a barátok 20,3\%-a, gyermekotthonban 18,2\%-a egyéb helyen 0,6\%-a, nem válaszolt 4,2 \%. Ebből arra a következtetésre jutottunk, hogy bár az intézmény lehetőséget biztosít a baráti kapcsolatok kialakítására, és vannak is ilyen kapcsolatok, a gyerekek több mint fele családban élö gyerekekkel köt barátságot. Korábban azt gondoltuk, hogy a gyerekek inkább az intézményben élő társaikkal barátkoznak. Az a tény, hogy a gyerekek több mint fele családban élő baráttal rendelkezik, arra utal, hogy az intézmények nyitottak, lehetővé teszik a tágabb környezetben élőkkel való kapcsolatok/barátságok kialakítását is. Ez segíti a gyerekek lakókörnyezetbe való integrációját, valamint abban is segít, hogy a családok müködésére vonatkozóan tapasztalatokat szerezzenek a családban élő társaik révén.

\section{8. ábra. Az intézményekben élök barátai lakóhely szerint}

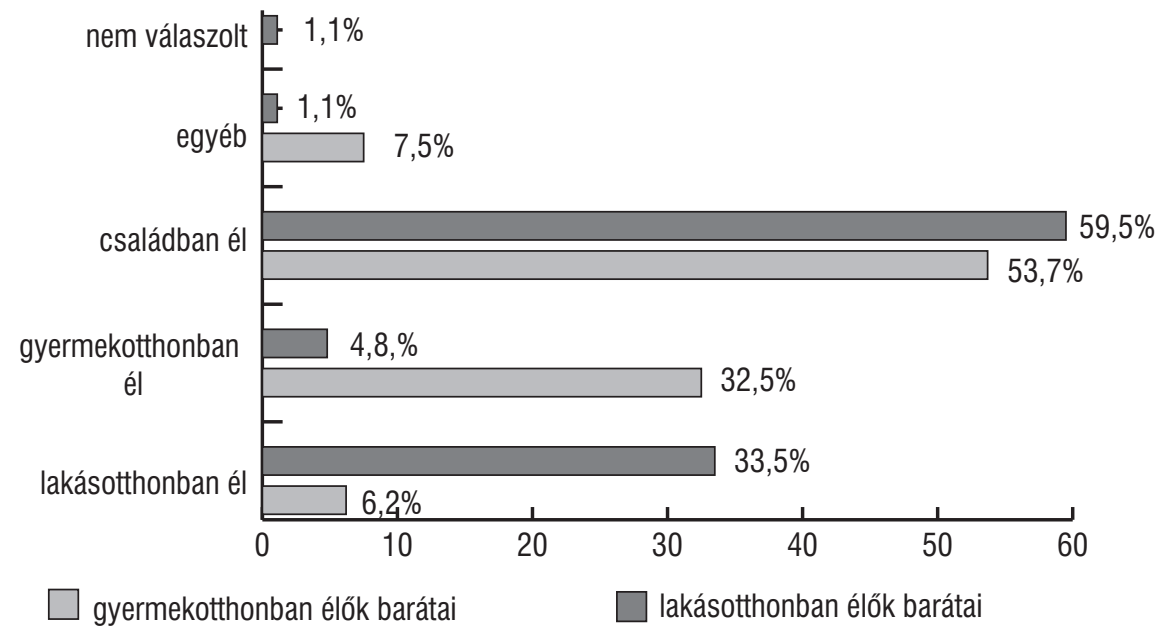

A fenti diagram (8. ábra) alapján megállapítható, hogy a gyermekotthonban élö gyerekek 53,7 \%-ának családban él a barátja, a lakásotthonokban 59,5\%-ra igaz ugyanez.

Ebből arra következtetünk, hogy mindkét intézménytípusban lehetősége van a gyerekeknek arra, hogy nem csak intézményben élő társaikkal, de családban élőkkel is barátkozzanak. Az adatok azt mutatják, hogy a lakásotthonban élők körében nagyobb arányú a családban élő gyerekekkel való baráti kapcsolatok kialakítása. Erre maga az intézmény elhelyezése is nagyobb lehetőséget teremt, mivel többnyi- 
re a településeken integráltan helyezkednek el az otthonok. Így lehetőség nyílik a szomszédságban élő gyerekekkel való kapcsolat kialakítására is.

A barátok lakóhelyét tekintve a nem cigány gyerekek barátainak 62,5\%-a saját családjában él, a cigány gyerekek kevesebb ilyen baráttal rendelkeznek, barátaik 49,3\%-a él saját családjában. Az adatok alapján jól látszik, hogy a cigány gyerekek számára kevesebb lehetőség van a családban élőkkel való baráti kapcsolatra.

A barátokkal együtt töltött idő tartalmát jellemzi, hogy a gyerekek többsége (65 \%) két óránál többet tölt baráti körben egy-egy alkalommal. Az együtt töltött idő tartamát tekintve a gyermekotthonban lakó gyerekek 68,2 \%-a két óránál többet tölt a barátaival alkalmanként, míg a lakásotthonokban $61,4 \%$-uk mondta ugyanezt.

A lányok több időt töltenek a barátaikkal. Két óránál többet a lányok 68,6\%-a, a fiúk $62 \%$-a tölt a barátai körében alkalmanként.

Az adatok szerint a cigány gyerekek több időt töltenek barátaik körében: 79,7 \% 2 óránál többet egy-egy alkalommal, míg a nem cigány gyerekek közül csak $49,2 \%$ mondta ugyanezt.

A kapott válaszok alapján megállapítható, hogy a gyerekek többsége $(75,6 \%)$ könnyen vagy nagyon könnyen meg tudja beszélni a problémáit a barátaival. 23,6uk azonban azt mondta, hogy nehezen vagy nagyon nehezen tudja megosztani a gondjait. A baráti kapcsolatok minőségére utal, hogy mind a gyerekotthonban élö gyerekek (74,2\%), mind a lakásotthonban élő gyerekek (77,2\%) könnyen vagy nagyon könnyen meg tudják beszélni a problémáikat a barátaikkal. A gyermekotthonban élők $24,2 \%$-a a problémáit nehezen vagy nagyon nehezen tudja megbeszélni, a lakásotthonban 22,8 \% mondta, hogy nehezen vagy nagyon nehezen tudja a gondjait barátaival megosztani. A lányok és a fiúk többsége azt válaszolta, hogy könnyen vagy nagyon könnyen meg tudja beszélni a problémáit a barátaival. A problémáikat a cigány gyerekek inkább meg tudják beszélni a barátaikkal 81,4 \%-uk könnyen vagy nagyon könnyen, míg a nem cigány gyerekek körében ez az arány $72,8 \%$-os.

Örkényi és munkatársai (2005) országos kutatásában gazdag társas kapcsolatokat talált. Az intézményben élő fiatalok 97,7 \%-a számolt be három vagy több barátról, az általuk végzett vizsgálatban. A megkérdezettek közül tíz fiatalból kilenc azt mondta, hogy könnyen vagy nagyon könnyen meg tudja beszélni a problémáit a barátaival.

Sem a barátok számának tekintetében, sem a barátokkal töltött idő mennyiségégében, sem pedig a problémák megbeszélésére vonatkozóan nem találtak különbséget a gyermekotthonban és a lakásotthonban élő fiatalok között, illetve a cigány és nem cigány gyerekek között sem.

Ettől eltérően kutatásunkban azt találtuk, hogy a lakásotthonban élő gyerekek több baráttal rendelkeznek, több olyan barátjuk van, aki családban él, mint a gyermekotthonban élő társaiknak. A barátokkal töltött időt tekintve megállapítható, hogy a nagy otthonban élő gyerekek több időt töltenek barátaikkal, mint a lakás- 
otthonban élök. Nem elhanyagolható azoknak az aránya egyik intézményben sem, akik nem tudják megosztani problémáikat a barátaikkal. Ezek a gyerekek alacsony társas támogatottsággal rendelkeznek, ami a későbbiekben a társadalmi beilleszkedésüket is nehezítheti. Örkényiék (2005) országos kutatásától eltérően azt tapasztaltuk, hogy az általunk megkérdezett cigány gyerekek több baráttal rendelkeznek, intenzívebb a társas kapcsolatrendszerük, mint a nem cigány társaiknak. Ez abban nyilvánul meg, hogy több időt töltenek a barátaikkal, illetve könnyebben meg tudják a problémáikat is beszélni velük, mint a nem cigány társaik. A cigány gyerekek társas kapcsolatrendszere zártabb. Az adatok alapján az látszik, hogy inkább barátkoznak az intézményben élő társaikkal, mint a családban élőkkel. Az országos kutatás adataival összevetve saját eredményeinket, megállapítható, hogy az országosnál nagyobb egyenlőtlenségek tapasztalhatók a gyermekvédelemben a Hajdú-Bihar megyei intézményekben. A gyerekek életkörülményeit, társas kapcsolathálózatát jelentősebben befolyásolja, hogy milyen típusú intézményben kerülnek elhelyezésre, mint az ország más intézményeiben.

\subsubsection{Szabadidő}

A szabadidő eltöltése jelentős hatással van a személyiségfejlődésére. Lehetővé teszi az egyén számára a pszichikai, fizikai feltöltődést, a művelődést. Többféle funkcióját különbözteti meg Kiss (2004), így a pszichoszociális, a társadalmi és a gazdasági funkciót. Társadalmi funkciói között említi a szerző a szabadidő szocializációs funkcióját. Ez azt jelenti, hogy az egyének megszerzik azt a tudást, azokat a képességeket, normákat, értékeket, viselkedési szabályokat, magatartási mintákat, attitüdöket, habitust, konfliktus megoldási módokat, a viselkedés és tapasztalás lényeges elemeit, amelyek révén egy csoportban élni, boldogulni tudnak. (Kiss, 2004) Ezt a funkciót különösen fontosnak tartjuk az intézményben élő fiatalok körében, mivel ezeknek a gyerekeknek a szocializációja sajátos körülmények között valósul meg. Az elsődleges szocializációs színteret, a családot rövidebb-hosszabb időre az intézmény váltja fel.

Feltételeztük, hogy a lakásotthonban élő fiatalok több programban vesznek részt, szabadidejüket tartalmasabb programokkal töltik, mint a gyermekotthonban élő társaik.

Megkérdeztük, hogy mennyi szabadidővel rendelkeznek az intézményekben élők egy átlagos hétköznapon. A kapott válaszok szerint, a fiatalok többsége $(95,9 \%)$ jelentős, napi két óránál több szabadidővel rendelkezik. Az Ifjúság 2004 kutatás adatai szerint a fiatalok 47\%-a 1-3 óra, 27 \%-a 4-6 óra szabadidővel rendelkezik egy átlagos hétköznapon. 
22. táblázat Rendelkezésre álló szabadidő

\begin{tabular}{|l|c|c|c|c|}
\hline \multirow{2}{*}{ Szabadidő } & \multicolumn{2}{|c|}{ Gyermekotthon } & \multicolumn{2}{c|}{ Lakásotthon } \\
\cline { 2 - 5 } & $\mathbf{N}$ & $\mathbf{\%}$ & $\mathbf{N}$ & $\mathbf{\%}$ \\
\hline 1óránál kevesebb & 2 & 3,0 & 1 & 1,8 \\
\hline 2-3 óra & 26 & 39,4 & 12 & 21,1 \\
\hline 3 óránál több & 37 & 56,1 & 43 & 75,4 \\
\hline Nincs szabadidő & 1 & 1,5 & 1 & 1,8 \\
\hline Összesen & 66 & 100 & 57 & 100 \\
\hline
\end{tabular}

A 22. táblázat adatai alapján az otthonokban élők szabadidejét összehasonlítva megállapítottuk, hogy egy átlagos hétköznapon a gyermekotthonban élők 56,1 \%-nak van 3 óránál több szabadideje, 1,5\% mondta azt, hogy nincs szabadideje. Ennél magasabb, $(75,4 \%)$ a lakásotthonban élök körében a 3 óránál több szabadidővel rendelkezők aránya.

A fiúk több szabadidővel rendelkeznek, mint a lányok. 3 óránál több szabadidővel bír a lányok 52,9 \%-a, a fiúknál jóval magasabb ez az arány, 74,6 \%. Nem találtunk különbséget az etnikum szerinti összehasonlításban a szabadidő tekintetében. Mind a két csoportban a többség napi 3 óránál több szabadidővel rendelkezik.

A szabadidőt jelentősen befolyásolja az egyéb tevékenységekre, így a tanulásra és az önellátásra fordított idő mennyisége. Kíváncsiak voltunk arra, hogy ezen tevékenységekkel mennyi időt töltenek a növendékek. Különbséget találtunk a gyermekotthon és lakásotthonok lakói között a tanulással töltött idő tekintetében. A napi 1-2 órát tanulással töltő gyerekek aránya a lakásotthonban magasabb $(71,9 \%)$, mint a gyermekotthonban, ahol ez az arány csak $(33,3 \%)$. Napi 3 órát tölt tanulással a lakásotthonokban élők 15,8\%-a, míg a gyermekotthonokban $10,6 \%$. A tanulásra időt nem fordítók aránya a gyermekotthonban magasabb (7,6 \%), mint a lakásotthonokban (1,8\%). Az adatok alapján megállapítható, hogy a lakásotthonban élő gyerekek több időt fordítanak a tanulásra, mint gyermekotthonban élö társaik. Az önellátással kapcsolatos tevékenységeket többségük (73,9\%) naponta 1-2 órában végzi. Az önellátásra vonatkozóan is azt találtuk, hogy a lakásotthonban élők közül többen (82,5\%) napi 1-2 órát töltenek önellátással kapcsolatos tevékenységgel, mint a gyermekotthonban $(66,6 \%)$. Az adatok alapján megállapítható, hogy a lakásotthonban élö gyerekek több időt fordítanak a saját maguk ellátására.

Ez azzal is magyarázható, hogy a lakásotthonban élőket jobban bevonják a háztartási teendők elvégzésébe. Ehhez a tárgyi feltételek is jobban megvannak, ahogy ezt az előző részben, az adatlapok, interjúk feldolgozásánál is láttuk.

A szabadidő eltöltésének színterére jellemző, hogy hétközben a gyerekek jelentős része az otthonban tartózkodik (43,1\%), barátoknál 18,7 \%-uk. A hétvégén is hasonló a szabadidő eltöltésének a színtere, elsősorban az otthonban töltik a 
szabadidejüket, ( $32,5 \%$ ) illetve a barátoknál 11,4\%. A hétvégén 12,2 \% -uk szórakozóhelyekre is eljár, így ez is a szabadidő színtere.

Mindkét nemre igaz, hogy a szabadidejüket hétközben elsősorban az otthonban, illetve barátoknál töltik. Hétvégén ez kiegészül a szórakozóhelyekkel. A fiúk közül többen töltik a hétvégét szórakozóhelyen, mint a lányok.

A cigány és nem cigány gyerekeket összehasonlítva a szabadidő helye hétköznap az otthon és a barátok mind a két csoportban. Hétvégén a szabadidő színterében találtunk különbséget. A cigány gyerekek jóval többen $(42,4 \%)$ töltik a hétvégét az otthonban, mint nem cigány társaik (20,3\%). Ez az eredmény összhangban van azzal a korábbi megállapításunkkal, hogy a cigány gyerekek kevesebb családban élő baráttal rendelkeznek, kevesebb külső kapcsolatuk van. Ez is oka lehet annak, hogy inkább az intézményben töltik a hétvégét.

Összehasonlítva a gyermekotthont és a lakásotthont, a szabadidő szempontjából megállapítható, hogy a lakásotthonban magasabb arányban vannak $(75,4 \%)$ azok, akik napi három óránál több szabadidővel rendelkeznek, mint a gyermekotthonban $(56,1 \%)$. A szabadidő eltöltésének a színterét hétközben mindkét intézményben elsősorban az otthon és a barátok jelentik. A gyermekotthonban a fiatalok nagyobb arányban $(71,2 \%)$ töltik a szabadidejüket a barátokkal, mint a lakásotthonban élők (50,9\%) Hétvégén szintén az otthonban és a barátoknál töltik leginkább az időt, de a gyermekotthonokban élők magasabb arányban (48,5\%), mint a lakásotthonban élők (38,6 \%). A szórakozóhelyeket a gyermekotthonokban élők többen látogatják, 19,7 \%-uk, míg a lakásotthonban élő 3,5\%.-a választja ezt a lehetőséget hétvégén.

A közmüvelődési intézmények színház, mozi, múzeum, hangverseny látogatottsága mindkét intézménytípusban alacsony. Elekes és Paksi (2005) összehasonlította a gyermekvédelmi gondoskodásban élők szabadidős szokásait a nem gyermekvédelmi gondoskodásban élők szokásaival. Azt tapasztalták, hogy az intézményekben élők az átlagnál gyakrabban töltik az idejüket „otthonülős” programokkal. Saját eredményeink egybeesnek ezzel a megállapítással, az általunk megkérdezettek is elsősorban az otthonban töltik szabadidejüket. Ezt figyelembe véve az intézményekre még nagyobb szerep/feladat hárul a szabadidős programok szervezés tekintetében.

A lakásotthonokban fontos kérdés a szabadidő eltöltése. Külső programokról minden lakásotthonban igyekeznek gondoskodni. A megkérdezettek közül legtöbben leggyakrabban kirándulni vagy sétálni mennek hétvégén. (Zsámbéki, 2004)

Az Ifjúság 2004 kutatás adatai szerint fiatalok többsége mind a hétvégét, mind a hétköznapokat otthon tölti, elzárva magát azoktól a lehetőségektől, amely rendelkezésére állna. A kutatás azt is megállapította, hogy a fiatalok életében meghatározó a barátokkal töltött idő. (Ifjúság, 2004)

A kutatási eredményeink alapján megállapítjuk, hogy az általunk megkérdezett fiatalok szabadidős színtere hasonlóságot mutat a nem intézményekben élő 
fiatalokéval, illetve az országos vizsgálat alapján a más gyermekotthonban élők szabadidős színtereivel.

A szabadidős tevékenységeket két csoportra bontottuk. Az első csoportba az aktív szabadidős tevékenységeket soroltuk. Aktívnak tekinthető minden olyan tevékenység, amelyben az egyén tevőlegesen részt vesz. Ide soroltuk a sporttevékenységet, a kulturális intézmények látogatását, a társas szórakozást. Megkérdeztük a gyerekeket, hogy a különböző kulturális intézményeket milyen gyakran veszik igénybe. A megkérdezettek közül havonta (9,8\%), ritkán (67,5\%), 21,1\%-uk pedig soha nem jár színházba. Moziba havi rendszerességgel 15,4\%-uk megy, ritkábban $62,6 \%$, soha $20,3 \%$. Az adatok alapján megállapítható, hogy a színház és a mozi látogatásának gyakorisága között nincs lényeges különbség, mind a két intézményt inkább ritkán látogatják a gyerekek. Ennek számos oka lehet. A kulturális intézmények látogatását befolyásolhatja a település típusa, ahol az intézmények találhatók. A kisvárosokban - ahol a vizsgált intézmények találhatók - kevesebb lehetőség adódik a kulturális intézmények látogatására. Nehézséget jelent az is, hogy csak a megyeszékhelyen található színház, és az utazási költség növeli a kiadásokat. Az Ifjúság 2000 kutatás adatai szerint a vizsgált egyik korcsoportnál sem fordult elö, hogy meghaladná a $10 \%$-ot azok száma, akik soha nem jártak színházban. Az adatok alapján megállapítható, hogy az intézményben élő gyerekek között kétszer akkora a színházba soha nem járók aránya, mint a fiatalok között általában.

9. ábra. Kulturális intézmények látogatásának gyakorisága a gyermekotthonban élők körében

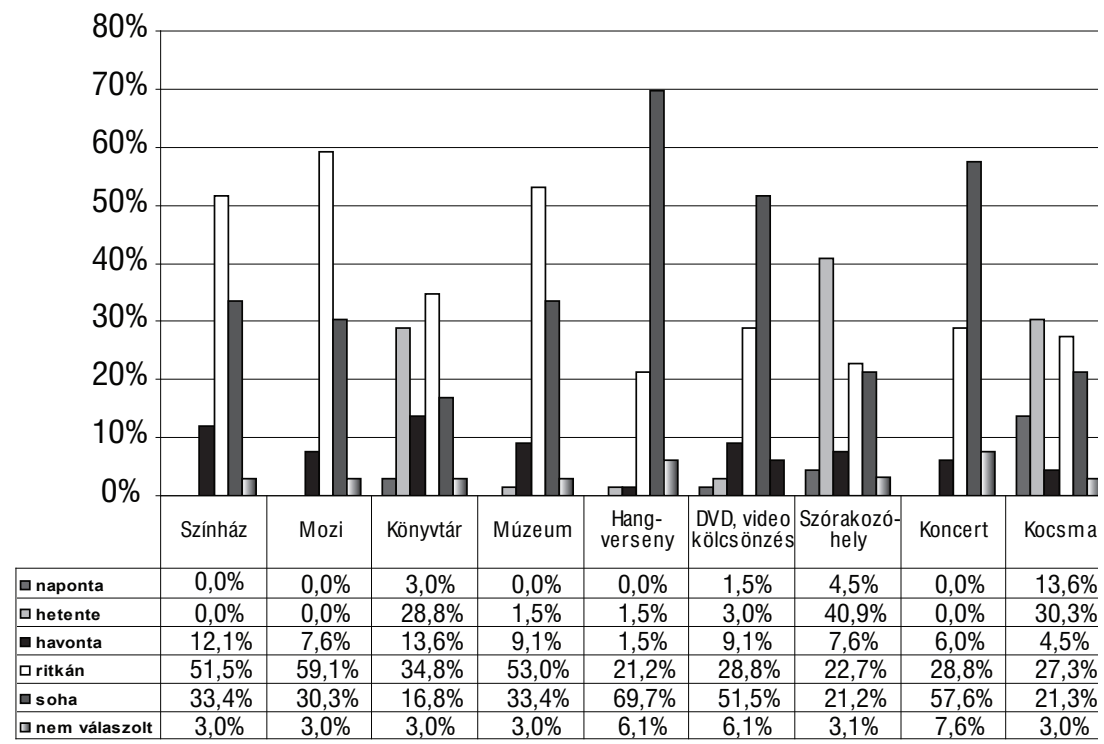


10. ábra. Kulturális intézmények látogatásának gyakorisága a lakásotthonban élők körében

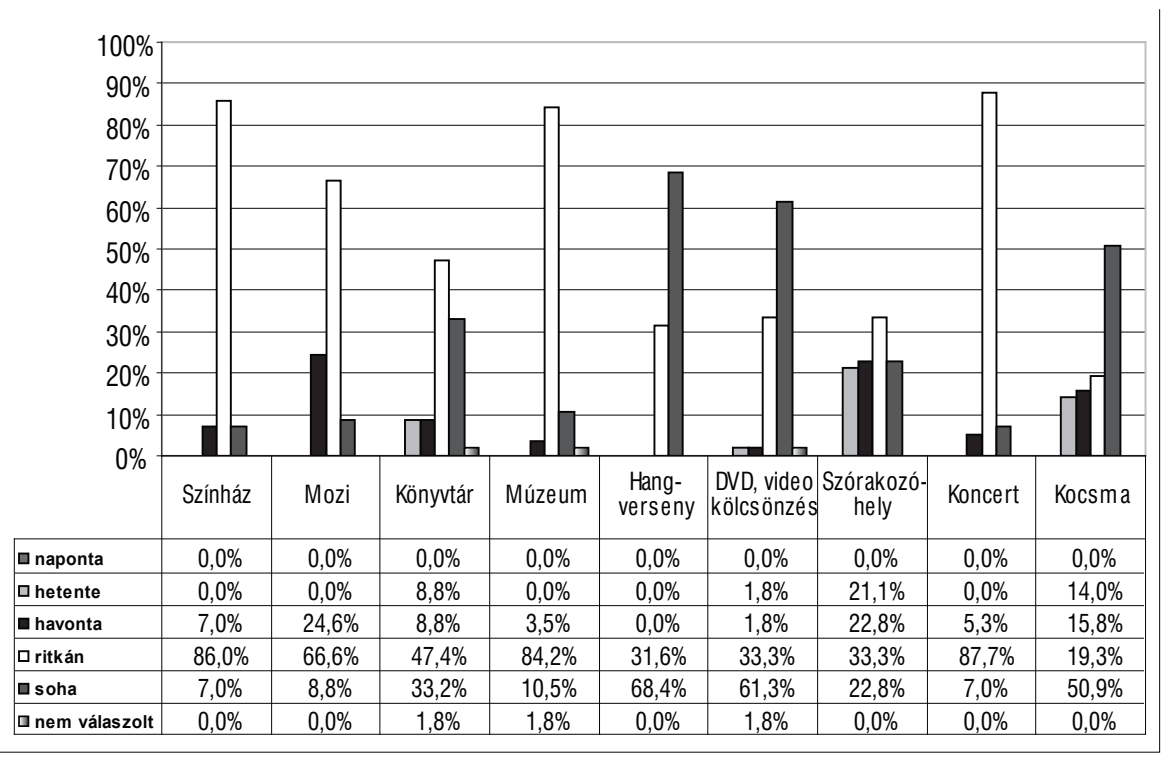

Az adatok alapján megállapítható, hogy a színházat mind a gyermekotthonban, mind a lakásotthonban lakók többsége ritkán látogatja. Moziba a lakásotthonban élők gyakrabban látogatnak, 24,6 \% mondta azt, hogy havi rendszerességgel jár moziba, míg a gyermekotthonban élők között csak 7,6 \% válaszolta ezt. (9.-10. ábra)

Nemek szerint összehasonlítva a színházba, moziba járás gyakorisága mindkét nemnél alacsony, többségük - több mint $60 \%$ - ritkán látogatja ezeket az intézményeket. A mozi tekintetében hasonló adatokat találtunk.

A színház és a mozilátogatás gyakoriságát tekintve a cigány gyerekek között többen vannak azok, akik soha nem látogatják ezeket az intézményeket, mint a nem cigányok között.

Elgondolkodtatóak a könyvtár igénybevételére vonatkozó adatok. A gyerekek 24,4\%-a soha, 40,7 \%-a ritkán megy könyvtárba, miközben ezek az intézmények mindkét településen megtalálhatók, és igénybevételük nem jár jelentős költséggel. Jelentős különbség van a könyvtárhasználatban a gyermekotthon és lakásotthonok között. A könyvtárat a gyermekotthon lakói közül többen látogatják hetente $(28,8$ \%), mint a lakásotthonban élők (8,8 \%). (9-10. ábra) Összehasonlítva az adatokat, megállapítható, hogy a gyermekotthonban élök gyakrabban használják a könyvtárat, mint a lakásotthon lakói. Ennek okát abban látjuk, hogy a gyermekotthon maga is rendelkezik könyvtárral, és mivel az intézményen belül van és könnyen hozzáférhető, gyakrabban használják a gyerekek. A könyvtárba soha nem járók között nem találtunk lényeges különbséget a lányok és a fiúk vonatkozásában. 
A cigány és nem cigány gyerekek szerinti összehasonlításban azt találtuk, hogy a könyvtárba soha nem látogatók között többen vannak a cigány gyerekek $(27,1$ $\%)$, mint a nem cigányok (18,6 \%).

Múzeumba a gyerekek többsége $(67,5 \%)$ ritkán vagy soha $(22,8 \%)$ nem jár. Az Ifjúság 2000 kutatás adatai szerint a fiatalok szívesen járnak múzeumba. A megkérdezettek 11\%-a egy hónapon belül, 54,3\%-a hat hónapon belül járt az intézményben. Korcsoport szerint a 16-24 évesek különösen fogékonyak a különféle kiállítások, gyüjtemények látogatására. Ezen a téren a kutatók eredményesnek látják a szocializációt. Az adataink alapján megállapítható, hogy az intézményben élö fiatalok kevésbé látogatják ezeket az intézményeket. A hangversenyen való megjelenés hasonló képet mutat. A gyerekek többsége soha nem $(69,1 \%)$ vagy ritkán (26\%) jár hangversenyre. Az Ifjúság 2000 adatai szerint is magas a hangverseny látogatását elutasító fiatalok aránya (44,5\%), de így is csak fele az általunk megkérdezett fiatalok arányának. A könnyedebb szórakozást biztosító koncertek látogatottsága sem túl jelentős a megkérdezettek körében. A többség ritkán, $(56,1 \%)$ vagy soha $(34,1 \%)$ nem látogat el koncertekre.

Különbséget találtunk a múzeumok látogatottságának gyakoriság között is a gyermekotthonok javára. A múzeumot soha nem látogatók között a gyermekotthonban élők 33,3 \%-a van jelen, ez az arány a lakásotthonokban alacsonyabb 10,5 \%. (9-10. ábra) A hangversenyek látogatottsága mind a két intézménytípusban alacsony. Múzeumba, hangversenyre a többség ritkán vagy soha nem jár, ebben a nemek közötti összehasonlításban sem találtunk különbséget.

A cigány és nem cigány gyerekek adatait összevetve azt találtuk, hogy a cigány gyerekek körében magasabb azoknak az aránya, akik soha nem $(32,2 \%)$ járnak múzeumba, mint a nem cigány gyerekek körében $(11,9 \%)$.

Az intézmények látogatásának gyakoriságát tekintve megállapítható, hogy az általunk megkérdezett fiatalok a magasabb kulturális értékkel bíró intézményeket (színház, múzeum, hangverseny) kevéssé látogatják, ebben a tekintetben „minimál befogadók".

Az Ifjúság 2004 kutatás szerint létezik egy „szubkulturálisnak” nevezhető tér, amely már egyértelmủen az ifjúsági kultúra része. Ezek közé sorolják a kutatók egyrészt a beszédcselekvés helyszíneit (kocsma, kávéház), másrészt a könnyed szórakoztatás helyszíneit (pl. diszkó). Ezeket a kutatók által „szubkulturálisnak” nevezett tereket az intézményben élő fiatalok is használják, különösen igaz ez a gyermekotthonban élőkre.

A szórakozóhelyek igénybevételére vonatkozóan a következőket találtuk. A gyerekek közel fele hetente $(31,7 \%)$, havonta (14,6\%) látogatja a szórakozóhelyeket. A szabadidő eltöltésének tehát gyakori módja a különböző szórakozóhelyeken, diszkóban való részvétel.

A szórakozóhelyeket a gyermekotthonban élök közel fele naponta vagy hetente látogatja $(45,4 \%)$, a lakásotthonban élők körében ez az arány alacsonyabb 
(21,1\%). (9-10. ábra) A szórakozóhelyek látogatásának gyakoriságát tekintve megállapítható, hogy a gyermekotthonban élők gyakrabban látogatják ezeket az intézményeket.

Nemek szerint összehasonlítva a szórakozóhelyek látogatottságát megállapítható, hogy a fiúk többen látogatják heti rendszerességgel (33,8 \%), mint a lányok $(27,5 \%)$. A szórakozóhelyeket, koncerteket a nem cigány fiatalok gyakrabban látogatják. Heti rendszerességgel jár a szórakozóhelyekre a nem cigány fiatalok 33,9 $\%$-a, szemben a cigány gyerekek $27,1 \%$-val.

A színház és szórakozóhelyek látogatására vonatkozó adatok összecsengenek az adatlapunk adataival. Az intézményvezetők elmondták, hogy a növendékek ritkán járnak színházba még a megyeszékhelyen is, ahol egyébként helyben van színház. A szórakozóhelyeket szívesen látogatják a fiatalok az intézményvezetők szerint is.

A kocsmákban, pubokban a megkérdezettek közel fele (40\%) naponta, hetente vagy havonta megjelenik. Az adatok alapján megállapítható, hogy a fiatalok által gyakran használt szabadidős színterek a kocsmák, a sörözők. A gyermekotthonokban élők gyakrabban látogatják ezeket a helyeket. 13,6 \%-uk naponta, 30,3\%-uk hetente. A lakásotthonban élök közül ezzel szemben napi gyakorisággal senki nem jár kocsmába, hetente 14 \%. (9-10. ábra) A kocsmákat, pubokat szintén a fiúk látogatják többen.

A kocsmákba, pubokba napi rendszerességgel a cigány gyerekek járnak többen 13,6 \%-uk, míg a nem cigány gyerekek 1,7 \%-a.

Az intézmények látogatásának gyakoriságát t-próbával vizsgáltuk. Az intézmény-látogatást mérő változókat gyakorisági skálán konvergáltuk. A gyermekotthonban, lakásotthonban élők intézménylátogatására vonatkozó átlagok különbözőségére voltunk kíváncsiak. Szignifikáns különbséget találtunk a színház, a mozi, a könyvtár, a koncert, a kocsma látogatását tekintve a gyermekotthon és a lakásotthon lakói között. A kapott eredmények szerint a lakásotthonban élők körében gyakoribb a mozi, színház, koncertlátogatás. A gyermekotthon lakói között a könyvtár és a kocsma látogatása gyakoribb.

Az aktív szabadidős tevékenységek közé tartozik a sportolás. A sporttal kapcsolatban megállapítható, hogy a megkérdezettek 38,2 \%-a sportol rendszeresen a tornaórákon kívül is. A legmagasabb arányt a napi egy órát sporttal töltők képviselik (42,3\%). Arra a kérdésre, hogy miért nem sportolnak, leginkább a lustaságot jelölték meg okként (35\%), időhiányra hivatkozott 8,9\% s mindössze 4,1 $\%$ mondta azt, hogy lehetőség hiánya miatt nem sportol. Különbséget találtunk a gyermekotthonban és a lakásotthonban élő fiatalok sportolási szokásaiban. Arra a kérdésre, hogy sportolsz-e a tornaórán kívül, a gyermekotthonban kevesebben válaszoltak igennel (30,3\%), mint a lakásotthonban élök (47,4\%). A sportra fordított idő tartamában is különbséget találtunk a lakásotthonok javára. A lakásotthonban élők nagyobb arányban $(56,2 \%)$ töltenek legalább napi egy órát sporttevékenységgel, mint a gyermekotthonban élő társaik (30,3\%). 
Az aktív szabadidős tevékenységek közé soroltuk a kirándulást és az üdülést. Egy éven belül a gyermekotthonban élők 57,6 \%-a, a lakásotthonban élők $93 \%$-a volt kirándulni. Az adatok alapján megállapítható, hogy a lakásotthonban élök gyakrabban vesznek részt kirándulásokon.

A szabadidős programokat mind a két intézményben elsősorban az otthon pedagógusai szervezik, leginkább őket követik az iskolai pedagógusok. A gyermekotthonban dolgozók szervezik a programok 47,5\%-át, a lakásotthonban ugyanez az arány $48,7 \%$.

A lakásotthonban élő gyerekek 19,3\%-a szervezi magának a szabadidős programokat, a gyermekotthonban élők 15,8 \%-a. Ebben a lakásotthonban élők nagyobb önállóságot mutatnak.

A szabadidős tevékenységek második csoportját a passzív szabadidős tevékenységek alkotják. Ide azokat a tevékenységeket soroltuk, amelyek nem igényelnek nagyobb testi, szellemi erőfeszítést. A passzív szabadidős tevékenységekhez sorolható többek között az olvasás. A megkérdezettek közül az elmúlt évben a legtöbben egy könyvet olvasott $22 \%$, kettőt 14,6 \%, 3-4-et 14,6 \% ötöt vagy többet $8,1 \%$. Az adatok alapján megállapítható, hogy az olvasás nem tartozik a kedvelt szabadidős tevékenységek közé az intézményekben élők körében, 40,7 \%-uk egyáltalán nem olvasott könyvet egy év leforgása alatt. Az olvasási szokások tekintetében a gyermekotthonban élö gyerekek között magasabb azoknak az aránya, akik az elmúlt évben egy könyvet elolvastak (25,8 \%) mint a lakásotthonban (17,5\%).

A fiúk és a lányok között különbséget találtunk az olvasás terén. A fiúk 45,1 \%-a mondta azt, hogy egyetlen könyvet sem olvasott az elmúlt évben, míg a lányoknak csak 35,3\%-a. Különbséget találtunk a cigány és a nem cigány gyerekek között is az olvasási szokásokban.

A cigány gyerekek fele mondta azt, hogy nem olvasott egy könyvet sem az elmúlt évben, a nem cigány gyerekeknek csak 28,8 \%-a válaszolt így.

Az újságok olvasása terén sem találtunk kedvezőbb képet. A válaszadók a 48\%-a olvas újságot. A legnagyobb arányban a Hajdú-Bihar Megyei Naplót olvassák, és jelentős a különböző bulvárlapok iránti érdeklődés. A megkérdezettek körében a Blikk, a Nők Lapja, a Story, különböző sportújságok a népszerüek, elsősorban a könnyed szórakoztatást, kikapcsolódást jelentő lapok. Többen olvasnak újságot a lakásotthonokban élők (59,6 \%), mint a gyermekotthonban élők (37.9 $\%)$. Az olvasott lapok minőségében nincs különbség, mind a két otthonban elsősorban a megyei napilapot és bulvár újságokat olvasnak. A lányok többen olvasnak rendszeresen újságot (54,9 \%), mint a fiúk (42,3 \%) Az olvasott lapok elsősorban bulvár jellegüek, ami a fiúk esetében sportújságokkal egészül ki. A cigány gyerekek jóval kisebb arányban - 28,8 \% - olvasnak rendszeresen újságot, míg a nem cigány gyerekek 66,1\%-a. Mindkét csoport elsősorban bulvárt olvas.

Az Ifjúság 2004 kutatás adatai szerint is csökkenö tendenciát mutat az olvasott könyvek száma. 2000-ben 13,3 könyvet olvastak a fiatalok, 2004-ben 10,7 köny- 
vet. A nyomtatott sajtó tekintetében elsősorban a bulvár lapokat, a helyi és regionális lapokat részesítik előnyben.

A tévénézés gyerekekre gyakorolt hatását számos kutatásban vizsgálták. A kutatások szerint a tévénézés a fiatalok élményfeldolgozását, világfelfogását is jelentősen befolyásolja.

Az agresszív viselkedésen túl a magatartászavarokért, a társas készség deficitjeiért, bizonyos tanulási nehézségekért vagy figyelemzavarokért is felelős lehet a média szocializációs hatása. (Pikó, 2005). A tévénézéssel töltött idő mennyisége az intézményekben élő fiatalok körében is igen jelentős. A válaszok szerint 19,5 $\%$ napi egy órát tölt tévénézéssel, $22,8 \%$ két órát, három órát $26,8 \%$, négy órát $13 \%$, öt órát $6,5 \%$. Az adatok alapján megállapítható, hogy a gyerekek közel fele naponta 2-3 órát tölt tévézéssel, így a szabadidős tevékenységek között vezető elfoglaltságot jelent ez a tevékenység. A napi tevékenységek között a zenehallgatás is jelentős időt foglal el. A megkérdezettek közel fele (48,8\%) naponta 1-2 órát tölt zenehallgatással, de jelentős a napi négy órát zenehallgatással töltők aránya is $(20,3 \%)$ Az adatok alapján jól látszik, hogy a tévézés mellett a zenehallgatás jelenti leginkább a kikapcsolódást a gyerekek számára.

23. táblázat. Tévézéssel és zenehallgatással töltött idő megoszlása

\begin{tabular}{|l|l|c|c|c|c|}
\hline \multirow{2}{*}{$\begin{array}{c}\text { Tévézéssel, } \\
\text { zenehallgatással } \\
\text { töltött idó }\end{array}$} & \multicolumn{2}{|c|}{ Gyermekotthon } & \multicolumn{2}{c|}{ Lakásotthon } \\
\cline { 3 - 6 } & N & $\%$ & N & $\%$ \\
\hline TV & -1 óra & 7 & 10,6 & 17 & 29,8 \\
\hline & -2 óra & 13 & 19,7 & 15 & 26,3 \\
\hline & -3 óra & 19 & 28,8 & 14 & 24,6 \\
\hline & -4 óra & 9 & 13,6 & 7 & 12,3 \\
\hline & -5 óra & 6 & 9,1 & 2 & 3,5 \\
\hline & -6 óra & 1 & 1,8 & - & - \\
\hline Nem néz tv-t & 2 & 3,0 & 1 & 1,8 \\
\hline Nem válaszolt & 9 & 13,6 & 1 & 1,8 \\
\hline Zene & -1 óra & 21 & 31,8 & 16 & 28,1 \\
\hline & -2 óra & 15 & 22,7 & 8 & 14,1 \\
\hline & -3 óra & 6 & 9,1 & 6 & 10,5 \\
\hline & -4 óra & 5 & 7,6 & 20 & 35,1 \\
\hline & -5 óra & 3 & 4,5 & 1 & 1,8 \\
\hline & - 6 óra & 1 & 1,8 & - & - \\
\hline Nem hallgat zenét & 3 & 4,5 & 2 & 3,5 \\
\hline Nem válaszolt & 12 & 18,2 & 4 & 7,0 \\
\hline
\end{tabular}


A 23. táblázat adatai alapján összehasonlítva a gyermekotthonban és a lakásotthonban élőket, a legtöbb időt a megkérdezettek mind a két intézményben tévézéssel és zenehallgatással töltik. A táblázat adatai alapján jól látszik, hogy a lakásotthonban élő gyerekek többet tévéznek, különösen a napi 1-2 órát tévénézéssel töltők tekintetében. A zenehallgatással töltött idő mennyisége a gyermekotthonban több, kivéve a napi négy órát zenehallgatással töltők köre, ott a lakásotthonban élők jóval nagyobb arányt $(35,1 \%)$ képviselnek. A kedvenc tévé- müsorokat áttekintve nem találtunk különbséget a két intézmény lakói között. Leginkább a sorozatokat, szappanoperákat nézik szívesen.

Az információs technikai eszközök használata színesíti a szabadidő eltöltésének lehetőségeit. Internet hozzáféréssel mind a gyermekotthonban, mind a lakásotthonban élők több mint $80 \%$-a rendelkezik. A gyermekotthonban élők nagyobb arányban $(42,4 \%)$ használják napi 1 - 2 órát az internetet, mint a lakásotthonban élő társaik $(35,1 \%)$. Az internetet mindkét otthon lakói leginkább az iskolában használják és csak másodsorban az otthonban. A gyermekotthon lakói közül 4,9 \% a teleházat is igénybe veszi internethasználat céljából. Email címmel a gyermekotthonban élök 54,5 \%-a, a lakásotthonban élők 68,4 \%-a rendelkezik. Megkérdeztük, rendelkeznek-e mobiltelefonnal. Az adatok alapján megállapítható, hogy mobiltelefonnal a gyermekotthonban élők kevesebben $(28,8 \%)$ rendelkeznek, mint a lakásotthonban élö társaik (54,4\%).

Az Ifjúság 2004 adatai szerint a fiatalok 59\%-a legalább havonta egyszer szokott internetezni. Otthoni internet a háztartások 24 \%-ban van. A fiatalok háztartásainak internet ellátottsága szempontjából leszakadó régiónak számít az észak-alföldi régió, ahol a háztartásoknak $16 \%$-a rendelkezik internetkapcsolattal. A kutatás adatai szerint a fiatalok körében az iskola, mint a használat elsődleges helye - igaz csökkenő mértékben -, de megmaradt.

A kutatások alapján megállapítható, hogy az internethasználatban fontos szerepe van az iskolának, függetlenül attól, hogy intézményben vagy családban élő fiatalról van-e szó.

A szabadidőre vonatkozóan a következő megállapításokat tesszük. A fiatalok többsége jelentős mennyiségű szabadidővel rendelkezik. A szabadidejüket hétvégén és hétköznap is elsősorban az otthonban és a barátokkal töltik. A hétvégi szabadidős színtér - elsősorban a gyermekotthonban élők körében az otthon és barátok mellett a szórakozóhelyekkel egészül ki. A hétvégi rokon illetve szülőlátogatás, mint lehetséges színtér nagyon alacsony arányú. Ennek oka az lehet, hogy a családdal való kapcsolattartás - ahogy azt a korábbiakban láttuk -, elsősorban a testvérekkel való kapcsolatot jelenti. A fentiek alapján arra a megállapításra jutottunk, hogy az otthonoknak igen nagy szerepük van a fiatalok szabadidejének szervezésében, mivel jelentős mennyiségü szabadidővel rendelkeznek, és idejük nagy részét is az otthonban töltik. A szabadidő szervezése segítheti a fiatalok társadalmi integrációját, mivel aktívan megjelenhetnek az adott település közmüvelődési 
és egyéb intézményeiben, azok rendezvényein. A szabadidő további jelentősége, hogy prevenciós értékkel bír a különböző szenvedélybetegségek megelőzésében, a galerik kialakulásának megelőzésében.

Elekes - Paksi (2005) kutatásában úgy találta, hogy a gyermekotthonban élő fiatalok szabadidős programjai között leggyakoribb tevékenység a számítógépen való játék.

A legalább heti rendszerességgel folytatott számítógépes játék aránya arra utal, hogy ez az egyik legelterjedtebb szabadidö eltöltési forma. Különösen igaz ez a fiúk vonatkozásában.

Csupán a lányoknál előzi meg ezt a gyakorisági adatok alapján a könyvolvasás vagy valamilyen más hobbi. A könyvolvasás egyébként a többi csoportban is a legtöbbet említett időtöltések közé tartozik.

Kutatásunkban ettől eltérő eredményeket kaptunk. A számítógépes játék kevéssé van jelen az általunk megkérdezettek szabadidős tevékenységei között. Ennek oka lehet többek között az, hogy - amint a dolgozat korábbi fejezetében bemutattuk - nem minden otthon rendelkezik számítógéppel. Az olvasást tekintve eredményeink teljesen eltérnek az országos kutatás eredményeitől. Az olvasás nem tartozik a kedvelt szabadidős tevékenységek közé. Az általunk megkérdezettek 40 $\%$ - a mondta azt, hogy egyáltalán nem olvasott könyvet az elmúlt egy évben. Más kutatások is az olvasási kedv csökkenéséről számolnak be a fiatalok körében. Az olvasási kedv csökkenését támasztja alá az a megállapításunk, hogy a különböző szabadidős tevékenységekre fordított időt tekintve a legtöbb időt tévézéssel és zenehallgatással töltik a növendékek mindkét otthontípusban. Az olvasást ezek a tevékenységek teljesen háttérbe szorítják az általunk megkérdezettek körében. A sportolás mint szabadidős tevékenység is kevéssé van jelen a mindennapjaikban, és ez nem a lehetőségek hiányára vezethető vissza. A kulturált szabadidőeltöltésnek színteret adó színház, mozi, hangverseny látogatottsága ritka mind a lakásotthonban, mind a gyermekotthonban élők körében. A növendékek számára a szabadidős programokat elsősorban az otthonok pedagógusai szervezik másodsorban pedig az iskolában tanító pedagógusok.

Hazai és Volentics (1986) a nevelőotthonokban élők szabadidős tevékenységére vonatkozóan megállapította, hogy a sporttevékenység csak kevéssé jellemző a fiatalok körében. A kulturálódást szolgáló tevékenységek (mozi, színház, rádió, hangverseny, tévénézés) a tévé- nézés kivételével igen kis számban szerepeltek. A szerzőpáros megállapította, hogy a nevelőotthonban a kulturális értékek elsajátítását túlzottan a tévére hagyatkozva látja el. (Hazai, Volentics, 1986) Bár a fenti kutatás még a korábbi nevelőotthoni rendszerben vizsgálta a szabadidős tevékenységet, több megállapítása az általunk vizsgált lakásotthonra és gyermekotthonra is igaz. Így a közművelődési intézmények látogatásának alacsony szintje, a rendszeres sportolás hiánya, a tévénézés, mint vezető szabadidős tevékenység ma is jellemző a vizsgált célcsoportban. Megállapítható, hogy a gyerekek elhelyezési 
feltételeinek átalakulása nem hozott jelentős változást a szabadidő eltöltésében, így az életkörülmények sem javultak lényegesen ebben a vonatkozásban.

\subsubsection{Iskolai tanulmányok/munkavégzés}

A képzettség a mobilitás és a felemelkedés legfontosabb feltétele. Az iskolai végzettség egyre inkább meghatározza az elérhető társadalmi helyzetet. (Andorka, 2006) Az ismeretek, készségek átadásával segíti az egyént a gazdaságban, a társadalomban való szerepek betöltésében, fejleszti a személyiségét és integrálja a társadalmi közösségekbe. Az intézményben élő fiatalok életében az iskolai végzettség társadalmi közösségbe való integráló funkciója különösen jelentős, mivel ezeknek a fiataloknak a társadalmi beilleszkedése több szempontból is nehezített. Az iskolai végzettség megszerzése alapozza meg az intézményből kikerülő fiatalok sikeres munkaerőpiaci részvételét, a társadalomba való beilleszkedésüket.

A kutatás idején a megkérdezettek 92,7\%-a tanulmányokat folytatott, mindöszsze 8 fö nem tanult. A gyerekek többsége, 30,1\%-a általános iskolában, 30,9\%-a szakiskolában tanult. Gimnáziumban 2,4\%, szakközépiskolában 11,4 \%, föiskolán 4,1\%, egyéb formában 14,6\%. Az egyéb formában tanulók között azok vannak, akik magántanulók, a vizsgálat idején tesznek érettségi vizsgát, speciális szakiskolában tanulnak vagy tanfolyamon vesznek részt.

24. táblázat A növendékek tanulmányaira vonatkozó adatok

\begin{tabular}{|l|c|c|c|c|c|c|}
\hline \multirow{2}{*}{ Megnevezés } & \multicolumn{2}{|l|}{ Gyermekotthon } & \multicolumn{2}{l|}{ Lakásotthon } & \multicolumn{2}{l|}{ Összesen } \\
\cline { 2 - 7 } & $\mathbf{N}$ & $\mathbf{\%}$ & $\mathbf{N}$ & $\mathbf{\%}$ & $\mathbf{N}$ & $\mathbf{\%}$ \\
\hline Általános iskola & 29 & 43,9 & 8 & 14,0 & 37 & 30,1 \\
\hline Szakiskola & 23 & 34,8 & 15 & 26,3 & 38 & 30,9 \\
\hline Gimnázium & 1 & 1,5 & 2 & 3,5 & 3 & 2,4 \\
\hline Szakközépiskola & 3 & 4,5 & 11 & 19,3 & 14 & 11,4 \\
\hline Főiskola & 2 & 3,0 & 3 & 5,3 & 5 & 4,1 \\
\hline Egyéb & 2 & 3,0 & 16 & 28,1 & 18 & 14,6 \\
\hline Nem válaszolt & 6 & 9,1 & 2 & 3,5 & 8 & 6,5 \\
\hline Összesen & 66 & 100 & 57 & 100 & 123 & 100 \\
\hline
\end{tabular}

A két intézményt összehasonlítva úgy találtuk, hogy a gyerekek többsége a gyermekotthonban és a lakásotthonokban is tanul. Az iskolatípust tekintve a lakásott- 
honokban többen tanulnak gimnáziumban, szakközépiskolában és föiskolán is. A 24. táblázat adatai szerint a lakásotthon lakói közül 19,3\% tanul szakközépiskolában, míg a gyermekotthonban ez az arány 4,5\%. Mindkét intézményben jelentős a szakiskolában tanulók aránya a gyermekotthonban 34,8 \%, a lakásotthonban 26,3 $\%$ tanul ebben az iskolatípusban. Az adatok alapján megállapítható, hogy a lakásotthonban élő gyerekek közül többen jutottak el az érettségit és felsőfokú tanulmányokat biztosító képzésig. A kapott eredményeket összehasonlítva az Ifjúság 2004 kutatás adataival a következőket állapítjuk meg: 2000-ben az iskolarendszerben tanuló 15-29 éves fiatalok 11\%-a, 2004-ben 13\%-a tanult szakmunkásképzőben vagy szakiskolában.

Az érettségit nem adó szakiskolai képzésben továbbtanulók aránya 1990-1991 és 2006-2007 között 44 \%- ról 22, 4 \%-ra csökkent. A középfokú beiskolázási arányok változása erős szelekció mellett ment végbe. A társadalom felső és középrétegei számára az utóbbi 15 évben az érettségit adó, valamint a felsőfokú továbbtanulás lehetőségét kínáló középfokú képzés (szakközépiskola, gimnázium) vált a népszerü perspektivikus továbbtanulási formává, mivel javult az ezekben az iskolákban megszerezhető végzettség munkaerőpiaci értéke. A szakiskola pedig egyre inkább a hátrányos helyzetű tanulók továbbtanulási formájává vált. (Liskó, 2008) Tehát, míg a fiatalok körében kevésbé jellemző a szakiskolában való továbbtanulás, addig az általunk megkérdezett fiatalok közül 30,9\% ebben az intézménytípusban tanul. A középiskolai tanulmányok terén a szakma megszerzését tartják fontosnak a fiatalok, ez a továbbtanulási motivációjukban is megjelenik, legtöbben szakiskolában tanulnának tovább. A szakma megszerzése azért is lehet fontos számukra, mert ez lehetővé teszi az önálló élet korábbi megkezdését.

A közép- és felsőfokú tanulmányok terén is különbséget találtunk a nemek között, a lányok javára. Ez a tendencia figyelhető meg a hasonló korú, családban élő fiatalok körében is. Szakiskolába a lányok 25,5\%-a, a fiúk 33,8\%-a jár. Gimnáziumba a lányok 3,9\%-a szemben a fiúk 1,4\%- val. Szakközépiskolába a lányok $15,7 \%$ - a, a fiúk 8,5\%- a jár. Főiskolai tanulmányokat a lányok 5,9\%-a, a fiúk 2,8\%-a folytat. Az adatok alapján jól látszik, hogy a lányok közül többen tanulnak tovább, többen szereznek magasabb iskolai végzettséget, mint a fiúk. A felsőfokú képzés erőteljes expanziójáról számol be az Ifjúság 2004 kutatás, amely elsősorban a föiskolai képzésben részt vevők arányának jelentős növekedésével járt. Főiskolai oktatásban 2004-ben az iskolarendszerben tanuló fiatalok 23\%-a vett részt, egyetemre 15\%-uk járt. Kutatásunk adatait áttekintve megállapítható, hogy a felsőoktatás expanziója kevéssé érintette az általunk megkérdezett fiatalokat. Ennek oka lehet egyfelől, hogy a gyerekek nagy tanulmányi lemaradásokkal kerülnek be az otthonokba, amit az intézmények már nem tudnak kompenzálni. Másfelől az oktatási intézményeknek sem sikerül a társadalmi hátterü esélykülönbségeket mérsékelni.

Az összehasonlításból látható, hogy a cigány gyerekek körében a nem tanulók aránya magasabb (10,2\%), mint a nem cigány gyerekek esetében (1,7\%). Jóval ma- 
gasabb arányban folytatnak általános iskolai tanulmányokat (40,7\%), mint a nem cigány társaik (22\%). Ennek oka, hogy a cigány tanulók körében több a túlkoros. Míg gimnáziumban a nem cigány gyerekek 3,4\%-a, szakközépiskolában 22\%-a tanul, addig a cigány gyerekek körében ez az arány jóval alacsonyabb, mindössze 1,7\%-os mindkét iskolatípusban. Felsőfokú tanulmányokat nem folytat egy cigány gyerek sem.

Az adatok alapján megállapítható, hogy a vizsgált intézményben a cigány gyerekek rosszabb mutatókkal rendelkeznek a tanulmányokra vonatkozóan, mint a nem cigány társaik.

A gyerekek nagy többsége (70\%) 6-11. osztályos, a legtöbben a 9. osztályban tanulnak (20,3\%). Az intézményben élők körében gyakori probléma a túlkorosság. Adataink szerint a vizsgált intézményekben élö gyerekeknek még a fele sem $(43,5 \%)$ tanul az életkorának megfelelö iskolai osztályban. Az iskolai osztály megjelölésekor jelentős válaszhiánnyal kellett számolnunk (31\%). Számításaink szerint így is a gyerekeknek legalább a $25,5 \%$-a túlkoros, azaz legalább 2 évvel idősebb az adott évfolyamon elvárható életkornál. A KSH adatai szerint a gyermekotthonban élő gyerekek között magas a túlkorosok aránya. Az általános iskolai tanulók $6 \%$-a túlkoros, akiknek több mint a fele legalább két évvel idősebb, mint az osztálytársai (KSH, 2004) Hasonló tendenciát találtunk az általunk vizsgált gyermekotthonban is.

A gyermekotthont és a lakásotthont összehasonlítva azt láttuk, hogy a gyermekotthonban élök körében alacsonyabb $(33,4 \%)$ az életkoruknak megfelelő iskolai évfolyamon tanuló gyerekek aránya, mint a lakásotthonban élőknél (56\%). Ezek az adatok a lakásotthonban élő gyerekek eredményesebb iskolai teljesítményére utalnak.

Az iskolai eredményeket befolyásolja a tanulással töltött idő. Tanulással az otthonok lakóinak több mint fele $(51,2 \%)$ napi 1-2 órát tölt. Különbséget találtunk a gyermekotthon és lakásotthonok lakói között ebben a vonatkozásban. A lakásotthonban élők között a napi 1-2 órát tanulással töltők aránya jóval magasabb (71,9\%), mint a gyermekotthonban élő gyerekek között $(33,3 \%)$. Az adatok alapján megállapítható, hogy a lakásotthonban élö gyerekek több időt fordítanak a tanulásra, mint gyermekotthonban élö társaik.

A gyerekek fele szerint - (49,3\%) - ha elakadnak a tanulásban, elsősorban az otthon pedagógusaitól tudnak segítséget kérni. Öket követik az iskolai pedagógusok (28,7\%), majd az osztálytársak (16,8\%) mint potenciális segítségkérési lehetőség. A tanulmányokban segítségként mind a fiúk, mind a lányok az otthon pedagógusaira számítanak elsősorban. Etnikum szerinti összehasonlításban is ugyanez a sorrend. Legnagyobb arányban az otthon pedagógusait jelölték meg mind a cigány $(46,1 \%)$, mind a nem cigány gyerekek $(51,8 \%)$. Az adatok alapján megállapítható, hogy az otthonoknak jelentős szerepük van az iskolai tanulás segítésében, és a gyerekek inkább támaszkodnak az otthon pedagógusainak a segítségére, mint az 
iskolában őket tanító tanárokra. Az otthonban dolgozó szakemberek - fejlesztő pedagógus, pszichológus, pedagógus - a gyerekek rendelkezésére állnak, ahogy ezt az adatlapunk adatai is mutatták. A két intézménytípus között kevés különbség van a szakember- ellátottság tekintetében.

A gyerekek tanulmányi terveit áttekintve azt találtuk, hogy a legtöbben a szakiskolákban tanulnának tovább, 46,3 \%. Ezt követi a föiskolai, egyetemi tanulmányok 13,8\%-kal és 7,3\%-kal, majd az érettségi és szakmaszerzés 11,4\%-kal. Az érettségi megszerzését 6,5\% tartotta fontosnak. Pusztán általános iskolai végzettséget csak 7,3\% kíván szerezni. A tervek áttekintése után megállapítható, hogy ahogyan az interjúk és az adatlapok mutatták, illetve, ahogyan a szakirodalom alapján is megállapítható a gyerekek elsősorban valamilyen szakma megszerzését tartják fontosnak. Az általános iskola elvégzését kevesen, csak 7,3\%-uk tekintette célnak. Úgy tünik, a gyerekek felismerték a tanulás fontosságát, illetve maguk az intézmények is motiválják őket legalább egy szakma megszerzésére. Ugyanakkor a terveket nem tartjuk reálisnak a föiskolai és egyetemi továbbtanulás tekintetében. A legtöbb gyerek az átlagos tanulmányi eredményeket jelölte meg tanulmányi eredményeire vonatkozóan, ami kevéssé valószínüsíti a föiskolai, egyetemi tanulmányokat. Továbbá a vizsgálat idején az összes otthont áttekintve mindössze 7 föt találtunk, akik föiskolai tanulmányokat folytattak, egyetemit pedig egyetlen növendék sem.

A 2004-es Ifjúságkutatás azt is megállapítja, hogy a társadalmi hátterü iskolázási különbségek nem csökkentek az eltelt időszakban. Az alacsony iskolai végzettségü szülők csoportjához tartozók számára változatlanul a szakiskolai kínál továbbtanulási lehetőséget. (Ifjúság, 2004) A kutatások szerint Hanák (1983), Veres-Brezovszky (1990), Vidra-Szabó (2001), Örkényi és munkatársai (2005) az intézményben élő gyerekek szülei alacsony iskolai végzettséggel rendelkeznek. Ezt a saját kutatási eredményeink is alátámasztják. A szülők iskolai végzettsége hatással lehet a fiatalok továbbtanulására, annak ellenére, hogy a továbbtanulás idején nem a családban élnek a fiatalok. Ennek oka részben az, hogy sokszor, mire az intézménybe kerülnek, jelentős lemaradással küzdenek a tanulmányok terén, amit az intézmények nem vagy nehezen tudnak kompenzálni. Az intézménybe való bekerülési adatok áttekintésekor láttuk, hogy a gyerekek többsége $(38,2 \%)$ 11-17 éves korában kerül be a rendszerbe. 
11. ábra. Az intézményekben élö gyerekek továbbtanulási tervei

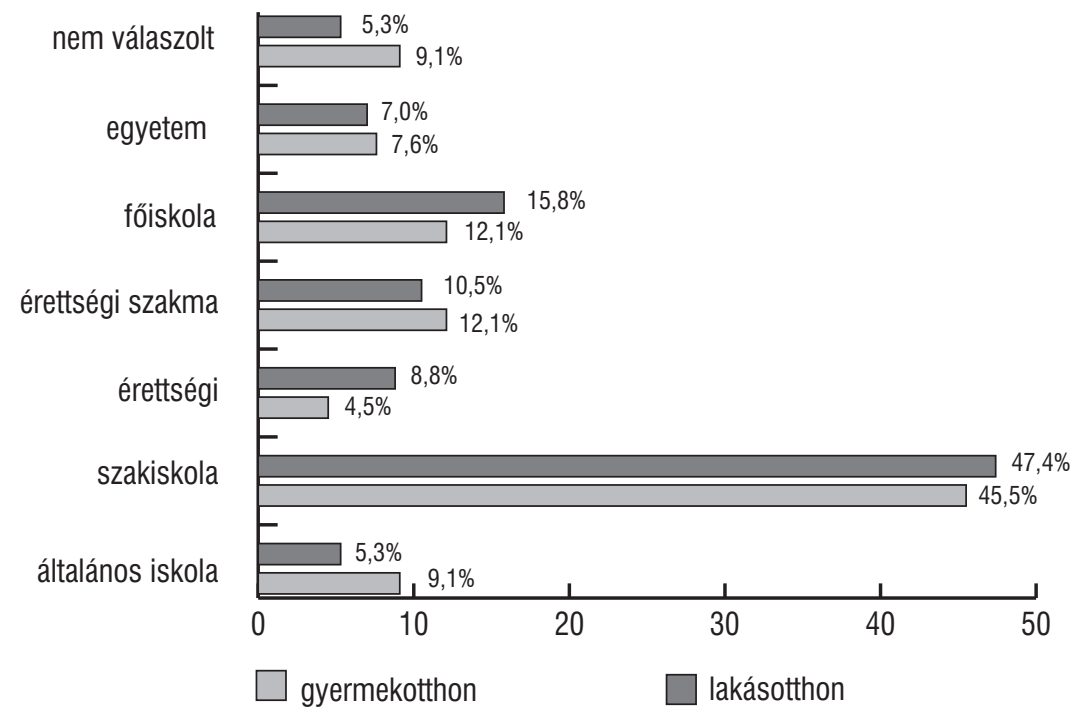

Mint utaltunk rá, a továbbtanulási tervekre vonatkozóan - a fenti diagram (11.ábra) adatai szerint - megállapítható, hogy mindkét intézményben a szakmaszerzést tartják a legtöbben fontosnak. Egy vonatkozásban találtunk lényeges különbséget a továbbtanulási tervekben. Ez pedig az általános iskolai végzettség. Általános iskolai végzettséget a gyermekotthonban élők 9,1\%-a kíván szerezni, míg a lakásotthonokban élők között ez csak 5,3\%. Az általános iskolai végzettség azonban kevéssé teszi lehetővé a munkaerőpiacon való részvételt. A továbbtanulási terveket illetően a fiúk közül jóval többen (11,3\%) gondolják úgy, hogy csak általános iskolai végzettséget szeretnének szerezni, mint a lányok (2\%.).

Mind a lányok, mind a fiúk szakiskolai végzettséget szeretnének a legtöbben ebben lényeges különbséget nem találtunk a nemek között. Érettségit és szakmaszerzést, illetve főiskolai végzettséget a lányok nagyobb arányban tüztek ki célul, mint a fiúk. Az adatok alapján megállapítható, hogy a lányok többen tanulnak közép- és felsőfokú képzésben, és terveik között is magasabb arányban szerepel ezeknek a tanulmányoknak az elvégzése, mint a fiúk esetében.

A cigány tanulók jóval nagyobb arányban $(13,6 \%)$ terveznek általános iskolai végzettséget, mint a nem cigány gyerekek $(1,7 \%)$. Mindkét csoportban szakmunkás végzettséget szeretnének a legtöbben. A cigány gyerekek jóval kisebb arányban kívánnak érettségit és főiskolai, egyetemi végzettséget szerezni, mint a nem cigány társaik.

Megkérdeztük azokat a fiatalokat is, akik nem folytatnak tanulmányokat, hogy mivel foglalkoznak. Összesen nyolc fót találtunk, aki nem tanul. 
Közülük öten dolgoznak, ketten munkanélküliek, egy fő pedig a vizsgálat idején tett szakmunkás vizsgát, már nem tanult és még nem dolgozott. A megkérdezettek közül hat főnek általános iskolai végzettsége van, egy fö szakközépiskolát, egy fő pedig szakiskolát végzett. Jelenlegi munkakörüket tekintve asztalosként, kertészként, számítástechnikai szakemberként dolgoznak. Azok, akik nem tanulnak, heten a gyermekotthonban élnek, egy fó pedig lakásotthonban. A vizsgált gyermekotthonban készült interjú szerint az alacsony iskolai végzettséggel rendelkező növendékeiknek a korábban létrehozott Hasznos Idő Központ területén próbálnak munkát biztosítani. Bár a Hasznos Idő Központ megszünt, néhány fiatalt még tudnak foglalkoztatni. Az itt alkalmazottak elsősorban kertészeti munkát, takarítást, az otthon mindennapjaihoz kapcsolódó tevékenységeket végeznek.

A tanulmányokra vonatkozóan a következő megállapításokat tesszük: a lakásotthonban élő gyerekek közül többen tanulnak közép- és felsőfokú képzést nyújtó intézményben, mint a gyermekotthonban élö társaik. A lakásotthonban élők tanulmányi mutatói jobbak (több időt töltenek tanulással, kevesebb a túlkoros közöttük, többen tanulnak a jobb munkaerőpiaci esélyeket kínáló szakközépiskolában, gimnáziumban.). A gyerekek többsége az otthonok pedagógusaitól kér segítséget a tanulmányaiban adódó nehézségek leküzdéséhez. Így az oktatás eredményességében felértékelődik az otthonok szerepe. A továbbtanulási tervekben elsősorban valamilyen szakma megszerzését tartják fontosnak a fiatalok, mind a gyermekotthonban, mind a lakásotthonban. Az intézmények számára nehézséget jelent, hogy a nagy lemaradással, későn bekerülő gyerekek esetében nehezen tudják kompenzálni a gyerekek tanulmányi eredményeit.

\subsubsection{Alkohol, drog, dohányzás kipróbálása, használata}

A gyermekvédelmi gondoskodásban élő fiatalok az átlagosnál veszélyeztetettebbek a szenvedélybetegségek szempontjából. Körükben az alkoholfogyasztás, a drogfogyasztás, a dohányzás nagyobb arányban fordul elő, mint családban élő társaiknál. (Elekes-Paksi 2005; Örkényi és mtsai, 2005)

Feltételeztük, hogy az általunk megkérdezett lakásotthonban élő fiatalok kevesebb alkoholt, drogot használnak, valamint kevesebbet dohányoznak, mint gyermekotthonban élő társaik, mert a lakásotthonokban élők kisebb létszámban vannak, így személyesebb kapcsolat alakulhat ki a felnőttekkel. A fiatalok többsége $(83,7$ \%) válaszolta azt, hogy kipróbálta már az alkoholt. Mindössze 16,3 \%-uk mondta azt, hogy nem. A fiúkra jellemző, hogy nagyobb arányban próbálták ki az alkoholt, mint a lányok. A fiatalok körében a leginkább fogyasztott alkohol a sör.

Az alkohol kipróbálásában - előzetes feltételezésünknek megfelelően - különbséget találtunk a gyermekotthon és a lakásotthon között. A 27. táblázat adatai alapján megállapítható, hogy a kipróbálók aránya a gyermekotthonban magasabb $(86,4 \%)$, mint a lakásotthonban $(80,7 \%)$. A fogyasztás gyakoriságát tekintve is 
a gyermekotthonban élők rendelkeznek rosszabb mutatóval. 27,3\%-uk mondta, hogy hetente iszik, míg a lakásotthonokban élők között ez az arány 10,5 \%.

25. táblázat .Az alkoholt kipróbálók és használók megoszlása

\begin{tabular}{|l|c|c|c|c|}
\hline \multirow{2}{*}{\multicolumn{1}{c|}{ Alkohol }} & \multicolumn{2}{c|}{ Gyermekotthon } & \multicolumn{2}{c|}{ Lakásotthon } \\
\cline { 2 - 5 } & $\mathbf{N}$ & $\mathbf{\%}$ & $\mathbf{N}$ & $\mathbf{\%}$ \\
\hline Kipróbálta & 57 & 86,4 & 46 & 80,7 \\
\hline Használat: naponta & 1 & 1,5 & - & - \\
\hline Hetente & 18 & 27,3 & 6 & 10,5 \\
\hline Havonta & 5 & 7,6 & 6 & 10,5 \\
\hline Ritkábban & 25 & 37,9 & 26 & 45,6 \\
\hline Soha & 17 & 25,8 & 19 & 33,3 \\
\hline
\end{tabular}

A fogyasztásra vonatkozóan a megkérdezettek közül 1 fó mondta azt, hogy naponta iszik, hetente 19,5\% (24) fö, havonta 8,9\%, ritkábban 41,5\%. Mindössze 29,3 $\%$ mondta azt, hogy soha nem iszik. Az alkoholfogyasztás gyakoriságát tekintve különbséget találtunk a fiúk és a lányok között. A fiúk 26,8 \%-a mondta, hogy hetente iszik, a lányok között ez az arány 9,8\%. Ugyanakkor a ritkábban történő alkoholfogyasztás tekintetében már nincs nagy különbség a fiúk és a lányok között. A fiúk 42,3\%-a , a lányok 39,2\%-a válaszolta, hogy ritkábban fogyaszt alkoholt. A lányok között az alkoholt soha nem fogyasztók nagyobb arányban vannak jelen, mint a fiúk körében. Etnikum szerinti összehasonlítás tekintetében a következőt találtuk: mind a cigány, mind a nem cigány gyerekek között több mint $80 \%$ az alkoholt kipróbálók aránya.

Az alkoholfogyasztás gyakoriságát tekintve a cigány gyerekek rendelkeznek rosszabb mutatókkal: 25,4\%-uk hetente iszik, míg a nem cigány gyerekeknek csak 13,6 \%-a válaszolt így. A cigány gyerekek közül naponta iszik 1,5\%, a nem cigány gyerekek körében nem találtunk naponta ivókat.

Murányi (2000) Szabolcs-Szatmár-Bereg megyei otthonokban végzett vizsgálata szerint az általa megkérdezett fiatalok fele 53 százaléka életében már többször ivott szeszes italt, de rendszeres fogyasztónak csak 13 százalékuk nevezhetö. A fiatalok egyharmada (34 százaléka) teljesen absztinens, mivel még nem fogyasztott életében alkoholt.

Örkényi (2005) és munkatársai hozzánk hasonló eredményre jutottak. Az általuk megkérdezettek 79,8 \%-a ivott már alkoholt életében. A leggyakrabban fogyasztott alkohol a sör és a röviditalok voltak. Az alkohol kipróbálása vizsgálatuk szerint nagyobb arányban jellemző a gyermekotthonban élő fiatalok között, 84,6 $\%$, mint a lakásotthonban élők között, 75,2\%. A fiúk nagyobb arányban próbálták ki az alkoholt, mint a lányok. A cigány etnikumú fiatalok körében gyakoribbnak találták a részegség előfordulását, mint a nem cigány etnikumúak körében. A gyer- 
mekotthonban élö fiatalok körében a többszöri részegség aránya is tendenciaszerűen magasabb, mint a lakásotthonban élőknél.

Elekes és Paksi (2005) kutatásában a fiatalok 56,4\%-a mondta azt, hogy fogyasztott már életében alkoholt. A nagyobb gyakoriságú alkoholfogyasztás a megkérdezettek 8,6 \%-ra volt jellemző. Megállapították továbbá, hogy amíg a gyermekotthonban élők alkoholfogyasztása mennyiségében és gyakoriságában is elmarad a 16 éves népesség fogyasztásától, addig a lerészegedés és a nagyivás mutatói meghaladják az átlagpopulációra jellemző mutatókat. A gyermekvédelmi gondoskodásban élőknél nem a család, hanem a baráti kapcsolatok alakítják a fogyasztási szokásokat.

A drogokat jóval kevesebben próbálták ki. A fiatalok 11,4 \%-a válaszolt úgy, hogy már próbálta. A kipróbálók többsége fiú. A drogfogyasztás gyakoriságát tekintve 10 fö mondta azt, hogy ritkábban szokott fogyasztani, $87 \%$, hogy soha, hat fö, 4,9 \% nem válaszolt. A drogot ritkábban használók között is a fiúk vannak többen. A drogokat tekintve a legtöbben marihuanát használtak, kilenc fö, extasyt két fö, valamint marihuanát és gyógyszert alkohollal egy fó, egy fö pedig marihuanát, gyógyszert és alkoholt, valamint ragasztót is használt. A drogok kipróbálói és felhasználói valamennyien a gyermekotthonban élnek. A lakásotthon lakói közül az adatok szerint senki nem próbálta ki és nem használta a drogokat.

A cigánygyerekek 15,3 \%-a próbálta ki a drogot, míg ez az arány a nem cigány gyerekek körében $6,8 \%$. A drogfogyasztás mértéke szerint is különbség van a két csoport között. A cigánygyerekek aránya a ritkábban fogyasztók között 11,9 \%-, míg a nem cigány gyerekek körében ez 3,4 \%.

Örkényi és munkatársai (2005) jóval nagyobb arányban találtak kábítószer-kipróbálókat az állami gondozottak körében. Saját bevallása szerint a megkérdezettek 41,4 \%-a használt már életében legalább egyszer valamilyen kábítószert. Leggyakrabban marihuanát, az alkoholt és a gyógyszert, majd az extasyt, illetve a ragasztó és oldószereket használták. A gyermekotthonban élők között magasabbnak találták a drogfogyasztást, mint a lakásotthonban élők körében. A drogfogyasztás nem különbözött lényegesen a cigány és a nem cigány etnikumú fiatalok körében, de a gyorsítót és a ragasztót a cigány fiatalok magasabb arányban próbálták ki.

Elekes-Paksi (2005) szerint a gyermekotthonban élők 37,8 \%-a kipróbált már eddigi élete során valamilyen visszaélésre alkalmas tiltott vagy legális szert. Gyógyszer és alkohol kombinált változatával minden ötödik intézetben élő gyerek próbálkozott. Többségük $(32,7 \%)$ biztosan drogfogyasztási céllal próbált valamilyen tiltott drogot. A drogok közül a gyermekotthonban élők leginkább a marihuanát $(24,1 \%)$, majd az inhalánsokat $(15,6 \%)$ és a partydrogokat $(7-10 \%)$ fogyasztják.

Murányi (2000) Szabolcs megyei vizsgálatában hozzánk hasonló eredményeket kapott. Megállapította, hogy az illegitim drog fogyasztása a fiatalok 8\%-ánál fordul elő a szomszédos megyében. A drogfogyasztás kipróbálását leginkább a 
kíváncsiság, a kellemes érzés iránti vágy motiválta, de nem elhanyagolható a valamilyen probléma miatti szerfogyasztás sem. (Murányi, 2000)

A dohányzásnál szintén magas a kipróbálók aránya, 73,2 \%. A fiúk és a lányok között különbséget találtunk. A fiúk 78,9 \%- a próbálta ki a dohányzást, a lányok közül $66,7 \%$. A dohányzás gyakoriságát tekintve a növendékek több mint fele, 54,5\%-a naponta dohányzik, ritkábban 6,5\%-uk, soha 38,2\%. A fiúk 60,6 \%-a naponta dohányzik. A 32. táblázat adatai alapján a dohányzásban lényeges különbséget találtunk a gyermekotthonban és a lakásotthonban élök között. A gyermekotthon lakói közül naponta dohányzik 65,2 \%, a lakásotthonban ez az arány 42,1 $\%$. A lakásotthonban élők 49,1\%-a mondta azt, hogy soha nem dohányzik, míg a gyermekotthonban csak $28,8 \%$ vélekedik így. Tehát az adatok alapján megállapítható, hogy a gyermekotthonban élők között magasabb a naponta dohányzók aránya, mint a lakásotthonokban élők körében.

26. táblázat. Dohányzást kipróbálók és dohányzás gyakoriság szerinti megoszlása

\begin{tabular}{|l|c|c|c|c|}
\hline \multirow{2}{*}{\multicolumn{1}{c|}{ Dohányzás }} & \multicolumn{2}{|c|}{ Gyermekotthon } & \multicolumn{2}{c|}{ Lakásotthon } \\
\cline { 2 - 5 } & $\mathbf{N}$ & $\mathbf{\%}$ & $\mathbf{N}$ & $\mathbf{\%}$ \\
\hline Kipróbálta & 54 & 81,8 & 36 & 63,2 \\
\hline Használat: naponta & 43 & 65,2 & 24 & 42,1 \\
\hline Ritkábban & 3 & 4,5 & 5 & 8,8 \\
\hline Soha & 19 & 28,8 & 28 & 49,1 \\
\hline
\end{tabular}

A dohányzást kipróbálók és használók között is magasabb arányban vannak jelen a cigány gyerekek. 71,2 \%-uk naponta dohányzik, míg a nem cigány gyerekek körében ez az arány 37,3 \%-os. A cigány gyerekek közül csak 23,7 $\%$ mondta azt, hogy soha nem dohányzik, a nem cigány gyerekek közül jóval többen, 54,2 \%-uk.

Összehasonlítva ezt az Örkényi (2005) és munkatársai által megkérdezett fiatalokkal, megállapítható, hogy szintén magas arányban próbálták ki a dohányzást, de tőlünk eltérően a lányok és a fiúk között nem találtak különbséget a kipróbálás tekintetében. A fiúk 90,3 \%-a, a lányok 87,2 \%-a próbálta ki a dohányzást. A saját eredményeinkhez hasonlóan úgy találták, hogy a cigány etnikumú fiatalok magasabb arányban próbálták ki a dohányzást, és közöttük magasabb a már nikotinfüggő, napi rendszerességgel dohányzók aránya is. A megkérdezettek 61,9\%-a naponta dohányzik, vagyis függőnek tekinthető. Az országos vizsgálat adatai szerint tehát még magasabb a naponta dohányzók aránya, mint az általunk vizsgált intézményekben. A gyermekotthonban és a lakásotthonban élőket a dohányzás szempontjából összehasonlítva is a saját vizsgálatunkhoz hasonló eredményekről számoltak be a kutatók. 
A gyermekotthonban élők között magasabb a napi szinten dohányzók aránya, mint a lakásotthonban élők körében.

Elekes-Paksi (2005) a gyermekvédelmi gondoskodásban élő fiatalokra vonatkozó országos kutatásában azt találta, hogy 61,7 \%-uk legalább egyszer kipróbálta a dohányzást. A fiúk és a lányok között nem talált különbséget a dohányzás tekintetében. A gyerekek több mint egy- harmada napi rendszerességgel dohányzik, a napi rendszerességgel dohányzók aránya kétszerese a nem intézményekben élő fiatalokhoz viszonyítva.

Murányi (2000) szerint a megkérdezett fiatalok 35 \%-a már kipróbálta a cigarettázást, egyötödük (21 százalék) még soha nem dohányzott, azonban a relatív többség (44 százalék) rendszeres dohányos.

A drog, alkohol, dohányzási szokásokra vonatkozó vizsgálatunkat áttekintve megállapítható, hogy az általunk megkérdezett fiatalok körében a drogfogyasztás kedvezőbb képet mutat, mint az országos vizsgálatok eredményei. Viszonylag kevesen, a megkérdezettek $10 \%$-a nyilatkozott úgy, hogy szokott drogot fogyasztani, de ritkán. Ennek okát elsősorban a drogfogyasztásban tapasztalható regionális különbségekben látjuk. Kutatások szerint a legkevésbé az észak-alföldi régió veszélyeztetett a drogfogyasztás szempontjából. Ezt támasztják alá Murányi (2000) Szabolcs-Szatmár- Bereg megyében végzett kutatásának eredményei is.

Az alkohol és dohányzás tekintetében azonban az országos adatokhoz hasonlóan magas fogyasztási arányokat találtunk. A kisebb létszámú lakásotthonokban élők szerhasználati szokásai kedvezőbb képet mutatnak a gyermekotthonban élők szokásaihoz képest.

Ennek hátterében az állhat, hogy a kisebb létszámú lakásotthonokban jobban „szem előtt” vannak a gyerekek, a kisebb közösség könnyebben átlátható. A lakásotthonban a személyes kapcsolatok kialakítására is több lehetőség nyílik - ahogy a korábbiakban bemutattuk -, a gyerekek gazdagabb társas kapcsolatrendszerrel rendelkeznek, és a problémáik megbeszélésére is több lehetőség nyílik. Az eredmények felhívják a figyelmet arra, hogy több más tényező mellett az intézményekben elhelyezett gyerekek életkörülményei is befolyásolhatják a szerhasználati szokásokat.

\subsection{7. Értékek, valláshoz való viszony}

Az értékek olyan kulturális alapelvek, amelyek kifejezik azt, hogy az adott társadalomban mit tartanak kívánatosnak és fontosnak, jónak vagy rossznak. (Andorka, 2006) Az értékek szociálpszichológiai szempontú értelmezése a társadalmi viszonyokhoz való kötődés fontosságát hangsúlyozza. E szerint az egyén számára kívánatos, fontosnak tartott értékeket mindig a megfelelő csoport, réteg (osztály, szervezet) érdekei, preferenciái határozzák meg. Az értékek segítségével a valamilyen társadalmi nagycsoporthoz tartozó egyén egyrészt könnyebben és biztonságo- 
sabban tájékozódik a társadalmi élet mindennapjaiban, másrészt elősegíti a csoport integrációját, segítve a világ „kollektív értelmezését”. (Csepeli, 1997) Az értékek jelentősen befolyásolják az ember viselkedését, magatartását. Vizsgáltuk, hogy az intézményben élö fiatalok milyen értékeket tartanak fontosnak életükben.

Azt kértük osztályozzák fontosság szerint (rendkívül fontos, nagyon fontos, inkább fontos, kevésbé fontos, egyáltalán nem fontos) a következő értékeket: békés világ, hagyományok, érdekes élet, gazdagság, pénz, hatalom, családi biztonság, szerelem, belső harmónia, igaz barátság, szabadság, vallásos hit.

A kapott válaszokat csoportosítottuk aszerint, hogy melyek azok az értékek, amelyeket a gyerekek több mint fele rendkívül fontosnak tart. A megkérdezettek közül legnagyobb arányban $(73,2 \%)$ a családi biztonságot tartották rendkívül fontosnak. Ezt követte sorrendben az igaz barátság, az önálló élet, a szerelem majd a szabadság, a békés világ és a belső harmónia. A gyerekeknek kevesebb, mint fele $(40,7 \%)$ tartotta rendkívül fontosnak a pénzt, a gazdagságot. 35\%-uk az érdekes életet, 26,8\% a hagyományokat nevesítette a rendkívül fontos dolgok között. A következő csoportba azokat az értékeket soroltuk, amelyeket a gyerekek egyáltalán nem tartanak fontosnak. Ilyen a vallásos hit (46,3\%) és a hatalom $(26 \%)$.

Megkérdeztük, hogy vallásos életet élnek-e a fiatalok. Ahogy az előbbiekben láttuk, nem tartják a vallásos hitet fontosnak a fiatalok, ez tükröződik az erre kérdésre adott válaszaikban is. 62,6\%-uk válaszolta azt, hogy nem vallásos, 34,1 \%-uk pedig, hogy a maga módján vallásos. Ennek megfelelően hittanra csak kevesen, mindössze 7,3 \%-uk jár. Annak ellenére ilyen alacsony a hittanon való részvétel, hogy a gyermekvédelmi törvényben a gyerekek jogai között felsorolásra kerül a vallási vagy lelkiismereti meggyőződés szabad megválasztásának, kinyilvánításának és gyakorlásának joga, valamint a hit-, és vallásoktatásban való részvétel joga, tehát a lehetőség megvan a vallás gyakorlására.

Az adatok alapján megállapítható, hogy a gyerekek közül a legtöbben azt az értéket tartották fontosnak, amely leginkább hiányzik, a családi biztonságot. A baráti kapcsolatokat is fontosnak tartják, ezek a leginkább elérhetőek a fiatalok számára, ahogy láttuk a korábbiakban, gazdag társas kapcsolatrendszerről adtak számot. Az adatok alapján megállapítható, hogy a megkérdezettek számára a legfontosabbnak a harmonikus élethez köthető immateriális értékek mutatkoztak. Ezek közé tartozik a családi biztonság, az igaz barátság, a szerelem, a békés világ, valamint a belső harmónia. Ezeket az értékeket magas arányban sorolták a rendkívül fontos dolgok közé. A fiatalok anyagi javakhoz való viszonyát jól tükrözik a kapott eredmények. A gyerekek kevesebb, mint fele tartotta rendkívül fontosnak a gazdagságot, pénzt (40,7\%).

Az Ifjúság 2004 kutatás eredményei szerint (33. táblázat) a fiatalok számára a legfontosabb érték a családi biztonság, ötös skálán 4,81-es értékkel. Ezt követi sorrendben a szerelem, a boldogság, majd az igaz barátság, a békés világ, a belső harmónia, a szabadság, a gazdagság és az érdekes élet. A kevésbé fontos értékek között a hatalom, a vallásos hit szerepel.(Ifjúság, 2004) 
27. táblázat. Mennyire fontosak az alábbi értékek az Ön életében? (az Ifjúság 2000, 2004 és a saját adatfelvétel összehasonlítása)

\begin{tabular}{|l|c|c|c|}
\hline & Ifjúság 2000 & Ifjúság 2004 & Saját adatfelvétel \\
\hline békés világ* & 4,8 & 4,66 & 4,2 \\
\hline hagyományok tisztelete & 3,8 & 3,66 & 3,47 \\
\hline érdekes élet & 4,02 & 3,89 & 3,93 \\
\hline gazdagság, pénz & 4,22 & 3,66 & 3,8 \\
\hline hatalom & 2,55 & 2,62 & 2,79 \\
\hline családi biztonság* & 4,84 & 4,81 & 4,46 \\
\hline szerelem, boldogság* & 4,76 & 4,77 & 4,41 \\
\hline belső harmónia* & 4,66 & 4,62 & 4,13 \\
\hline igaz barátság & 4,64 & 4,69 & 4,61 \\
\hline szabadság & 4,56 & 4,51 & 4,44 \\
\hline vallásos hit* & 2,61 & 2,98 & 2,35 \\
\hline
\end{tabular}

Egymintás t-próbával végzett vizsgálatunk adatai szerint néhány érték tekintetében a mintánk szignifikánsan eltér az Ifjúság 2004 kutatás eredményeitől. A 25. táblázatban a csillaggal megjelölt értékek, így a békés világ, a családi biztonság, a szerelem, boldogság, a belső harmónia és a vallásos hit szignifikánsan különbözik az Ifjúság 2004 adataitól. Az általunk megkérdezett gyerekek körében a megjelölt értékek kevésbé fontosak, mint az Ifjúság 2004 kutatásban részt vevő fiatalok körében.

A 26. táblázat adatai alapján áttekintjük, van-e különbség a lakásotthonok és a gyermekotthonok lakói által adott válaszokban. 
28. táblázat. Mennyire fontosak az alábbi értékek az Ön életében? (az Ifjúság 2004 és a gyermekotthoni, lakásotthoni adatfelvétel összehasonlitása)

\begin{tabular}{|l|c|c|c|}
\hline & Ifjúság 2004 & Gyermekotthon & Lakásotthon \\
\hline békés világ & 4,66 & $4,28^{*}$ & $4,11^{*}$ \\
\hline hagyományok tisztelete & 3,66 & 3,53 & 3,39 \\
\hline érdekes élet & 3,89 & 3,95 & 3,89 \\
\hline gazdagság, pénz & 3,66 & 3,85 & 3,75 \\
\hline hatalom & 2,62 & 2,91 & 2,65 \\
\hline családi biztonság & 4,81 & $4,37^{*}$ & $4,56^{*}$ \\
\hline szerelem, boldogság & 4,77 & $4,32^{*}$ & 4,52 \\
\hline belső harmónia & 4,62 & $3,95^{*}$ & $4,34^{*}$ \\
\hline igaz barátság & 4,69 & 4,58 & 4,63 \\
\hline szabadság & 4,51 & 4,4 & 4,49 \\
\hline vallásos hit & 2,98 & $2,6^{*}$ & $2,07^{*}$ \\
\hline
\end{tabular}

A rendkívül fontosnak tartott családi biztonság tekintetében kevés különbség van a két intézménytípus között. Ötös skálán mind a gyermekotthon $(4,37)$ lakói, mind a lakásotthon $(4,56)$ lakói rendkívül fontosnak tartják a családi biztonságot.

A lakásotthonok lakói 5-ös skálán mérve magasabbra értékelték a szerelmet $(4,52)$, a szabadságot $(4,49)$, a belső harmóniát $(4,34)$, mint a gyermekotthon lakói. Tehát a lakásotthonban élők számára ezek az értékek fontosabbak, mint a gyermekotthonban élők számára.

A gyermekotthonban élők számára magasabb értékkel bír - így fontosabb - a békés világ $(4,28)$, az érdekes élet $(3,95)$, a gazdagság, a pénz $(3,85)$, a hagyományok $(3,53)$, a hatalom $(2,91)$, a vallásos hit $(2,6)$, mint a lakásotthonban élőknél.

Az adatok alapján megállapítható, hogy a különböző típusú intézményben élők egyaránt fontosnak tartják a családi biztonságot. A 30. táblázat adataiból az is kiderül, hogy a gyermekotthonokban és a lakásotthonokban élők körében is szignifikáns különbség van az Ifjúság 2004 kutatás adataihoz képest a békés világ, a családi biztonság, a belső harmónia és a vallásos hit tekintetében. (Csillaggal jelöltük.) Ezek az értékek kevésbé fontosak az általunk megkérdezettek számára, mint a fiataloknak általában. Az is jól látszik, hogy a lakásotthonban élők kevésbé térnek el a családi biztonság, a belső harmónia, a hatalom, az igaz barátság, mint fontos érték tekintetében az Ifjúság 2004 adataitól, mint a gyermekotthonban élők. A gyermekotthonban élők a szerelemet és a boldogságot kevésbé tartják fontos értéknek, mint a lakásotthonban élők vagy az országos vizsgálatban megkérdezett 
fiatalok. A táblázat adatai alapján megállapítható, hogy a gyermekotthonban élők számára a materiális értékek fontosabbak - pl. a pénz, a gazdagság - mint a lakásotthonban vagy az Ifjúság 2004 kutatásban megkérdezett fiatalok körében.

Összevetve a kapott eredményeket, megállapítható, hogy a fiatalok körében fontos értéknek számít a családi biztonság, függetlenül attól, hogy intézményben vagy családban élnek-e. Az általunk vizsgált intézményben élő fiatalok körében azonban a baráti kapcsolatok átlagértéke magasabb, mint a családi biztonság értéke. Ez igaz mind a gyermekotthonban, mind a lakásotthonban élők körében. Ez a tendencia nem érvényesül az Ifjúság 2004-ben megkérdezettek körében. Ott a családi biztonság képviseli a legmagasabb értéket. Tehát az általunk megkérdezettek számára a baráti kapcsolatok fontosabbak, mint a családi biztonság. Ez megerősíti azt a korábbi megállapításunkat, hogy az intézményben élő gyerekek számára kiemelt jelentősége van a baráti kapcsolatoknak.

\subsubsection{Intézeti környezetre vonatkozó kérdések, elégedettség, jövöterv}

A gyermekek életkörülményeit jelentősen meghatározza, hogy milyen környezetben kerültek elhelyezésre. A lakásotthonok létrejöttével - ahogy azt a dolgozat előző fejezetében részletesen bemutattuk - lényegesen jobb tárgyi feltételek közé kerültek a gyerekek. Feltételezzük, hogy a lakásotthonban élő gyerekek elégedettebbek az otthon környezetével, nevelőikkel jobb kapcsolatban vannak, valamint könnyebben meg tudják osztani problémáikat velük, mint a gyermekotthonban élő társaik. A gyerekek többségének $(85,4 \%)$ tetszik az a szoba, amelyben él. Megkértük őket, osztályozzák 1-5-ig az otthont az iskolai osztályzatnak megfelelően. Legnagyobb arányban 4-es és 5-ös osztályzatok születtek. A gyerekek 35,8 \%-a 4-est adott, 41,5 \%-uk pedig 5-ösre értékelte az otthont. Az osztályzatok átlaga 4,15. Ebből arra következtetünk, hogy az otthonban található feltételekkel a gyerekek többsége elégedett. Arra a kérdésre, hogy mit szeretnek a legjobban, az otthonban a gyerekek 41,3\%-a válaszolta azt, hogy mindent, $21 \%$ a felnőtteket, 15,7 \% a gyerekeket jelölte meg. Mindössze 7,5 \%-uk mondta azt, hogy semmit nem szeret az otthonban.

A gyermekotthont és a lakásotthont összehasonlítva azt találtuk, hogy a lakásotthonban élőknél magasabb $(91,2 \%)$ azoknak az aránya, akiknek tetszik az a szoba, amelyben élnek, mint a gyermekotthonban élőknél (80,3\%). A lakásotthonban élők otthonnal való nagyobb mértékü elégedettsége az otthon osztályozásában is megmutatkozik.

A gyermekotthonban élők osztályzatának átlaga 3,95, a lakásotthonban élőké 4,37. A lakásotthon lakói közül többen (49,1\%) adtak 5-ös osztályzatot, mint a gyermekotthon lakóinak (28\%). Arra a kérdésre, hogy mi az, amit a legjobban szeretnek az otthonban, a lakásotthonban élők közül többen (49,1\%) mondták azt, hogy mindent, mint a gyermekotthonban élők (37,9\%). 
A gyermekotthonban élők azonban mind a gyerektársaikat, mind a felnőtteket magasabb arányban jelölték meg olyan személyként, akiket a legjobban szeretnek. Az adatok alapján megállapítható, hogy az otthon körülményeivel a lakásotthonban élők elégedettebbek, mint gyermekotthoni társaik.

Az intézeti bánásmód minősége jelentősen hat a gyerekek életkörülményeire, amit az is befolyásol, hogy bevonják-e őket a róluk szóló döntésekbe. A gyerekek 61,8 \%-a válaszolta azt, hogy igen, 30,9 \%-uk szerint néha igen, néha nem. Mindössze 4,9 érezte úgy, hogy nem vonják be az őt érintő döntésekbe. A lakásotthonban élők nagyobb arányban (66,7 \%) érezték úgy, hogy bevonják őket a róluk szóló döntésekbe, mint a gyerekotthon lakói $(57,6 \%)$. A néha bevonják, néha nem válaszlehetőséget is magas arányban jelölték meg a gyerekek, a gyermekotthonban élők 28,8 \%-a, a lakásotthonban élők 33,3 \%-a. Az intézménnyel való elégedettséget növelheti, ha a gyerekek úgy érzik, hogy van beleszólásuk az őket érintő kérdésekbe. A gyermeki jogok között szerepel a véleménynyilvánítás joga, ami azt jelenti, hogy a gyereket a személyét érintő kérdésekben meg kell hallgatni, tájékoztatni kell. A kapott válaszokból az látszik, hogy az intézmények ezt a kötelezettségüket nagyrészt betartják.

A magyar nyelvű szakirodalomban az elmúlt években jelent meg a rendszerbántalmazás fogalma. A kliensek védelmére, támogatására, segítésére létrehozott, müködtetett ellátórendszer és intézményei nem megfelelően látják el a feladatukat, illetve tovább rontják, nehezítik a gondozásra, ellátásra, segítségre szorulók problémáit, életét. Ide sorolja továbbá a szerző azt is, ha az intézmények dolgozói elmulasztják, vagy nem jól végzik a feladataikat. (Herczog, 2007)

A megkérdezett gyerekek többsége $(74,8 \%)$ nemmel válaszolt arra a kérdésre, hogy bántak-e velük rosszabbul, mint a lakótársaikkal. 12,2 \%-uk érezte úgy, hogy bántak vele rosszabbul, mint társaival. Összehasonlítva a két intézménytípust, megállapítható, hogy a gyermekotthonban élök közül többen $(15,2 \%)$ érezték úgy, hogy bántak velük rosszabbul, mint a lakásotthonban élők (8,8 \%). A gyerekek döntő többsége azonban mind a gyermekotthonban, $(71,2 \%)$ mind a lakásotthonban $(78,9 \%)$ azt mondta, hogy nem érezte azt, hogy rosszabbul bántak volna vele, mint a társaival. A válaszok alapján megállapítható, hogy a gyerekek többsége elégedett az intézeti bánásmóddal. A gyerekek elégedettségéhez az is hozzájárulhat, hogy az intézményekben jól képzett szakemberek dolgoznak, akik rendszeresen továbbképzéseken is részt vesznek. Ezt alátámasztják az adatlapok adatai, illetve az intézményvezetőkkel készült interjúk is.

Megvizsgáltuk a szökéseket, mert ez tükrözi a gyerekek biztonságérzetét és az otthonhoz füződő érzelmi kapcsolatát. A gyerekek kisebb hányada (36,6 \%) számolt be arról, hogy volt már arra példa, hogy megszökött az intézményböl. A szökések száma 1 és 11 között van. A legtöbben egyszer szöktek (17,9\%), a kétszer szökők aránya 4,9 \%. 10-11-szer csak néhányan próbálkoztak szökéssel. A szökések okát tekintve a legtöbben a hiányzó családot, majd az unalmat, a szabad élet utáni vágyat jelölték meg. 
Az egyik növendék elmondása szerint azért szökött, mert „nem szeretem, ha szabályok közt kell élnem, vágyok a szabad élet után”. A legtöbben azonban „hiányzott anyukám”, „vágytam haza”, „hiányzott a családom” válaszokat adtak. Az intézményekben tapasztalható szökések száma jelentős különbséget mutat a gyermekotthonban és a lakásotthonban. A szökések aránya a gyermekotthonban lényegesen magasabb, itt a gyerekek $53 \%$-a már szökött, ez az arány a lakásotthonban csak 17,5\%. A szökések számát tekintve is kedvezőbb a lakásotthonok helyzete, onnan 1-4 alkalommal történt már szökés, míg a gyermekotthonban 1-11 alkalommal. A gyermekotthonban élők közül nagyobb arányban $(24,2 \%)$ mondták azt, hogy egyszer szöktek, mint a lakásotthonban élök (10,5 \%). Az adatok alapján megállapítható, hogy a gyermekotthonban élő gyerekek kétszer gyakrabban szöknek meg, mint a lakásotthonban élö társaik. A lakásotthonból való szökések alacsonyabb arányát - a dolgozat korábbi fejezetében bemutattuk - az intézményvezetőkkel készült interjúk is megerösítik. Az interjúk szerint csökkent a szökések száma a lakásotthonokban, de a gyerekek egy jól körülhatárolható csoportjára továbbra is jellemző.

A gyerekek lakótársaihoz, nevelőihez való viszonyát úgy próbáltuk felmérni, hogy megkértük őket, értékeljék a következő állításokat a következőképpen teljesen egyetértenek, egyetértenek, részben értenek egyet, nem értenek egyet, egyáltalán nem értenek egyet.

A „lakótársaim többsége kedves és segítőkész” állítással a gyerekek közel fele $(49,6 \%)$ teljesen egyetértett, vagy egyetértett. Az adatok alapján megállapítható, hogy a gyerekek közel fele kedvesnek és segítőkésznek tartja a lakótársait, további $39 \%$ gondolja úgy, hogy részben kedvesek és segítőkészek a társai. A lakótársaim többsége kedves és segítőkész állítással a lakásotthonban élők nagyobb arányban (56,2\%) értettek teljesen egyet vagy egyet, mint a gyermekotthonban élők (44\%). A lakásotthonban élők társaikkal való nagyobb mértékü elégedettségének oka lehet, hogy lényegesen kevesebben vannak egy szobában elhelyezve, így a konfliktusok száma is jóval kevesebb lehet.

Arra az állításra, hogy lakótársai elfogadják olyannak, amilyen, 68,3\%-uk mondta azt, hogy egyetért, vagy teljesen egyetért. $24,2 \%$ részben értett ezzel egyet. Ezzel az állítással mind a gyermekotthonban élők többsége, $(69,7$ \%) mind a lakásotthonokban élők többsége, (66,7\%) teljesen egyetértett vagy egyetértett. Az adatok azt mutatják, hogy a gyerekek társai többnyire segítókészek és elfogadják egymást olyannak, amilyenek. Ez azért fontos, mert a társakkal való együttmüködés jelentősen hat a fiatalok mindennapi életére.

Azzal az állítással, hogy „,a nevelőim többsége kedves és segítőkész” 77,2\% teljesen egyetértett vagy egyetértett, részben értett egyet 13,8\%. Hasonló arányú válaszokat kaptunk a nevelőim többsége elfogad olyannak, amilyen vagyok állításra is. Megállapítható, hogy a gyerekek többsége elégedett a nevelőkkel, kedvesnek és segítőkésznek tartja őket. 
A gyerekek többségének (74 \%) megítélése szerint a nevelők elfogadják őket olyannak, amilyenek. A lakásotthonok növendékei magasabb arányban $(89,5 \%)$ értettek teljesen egyet vagy egyet azzal az állítással, hogy a nevelőim többsége kedves és segítőkész. A gyermekotthonban élők között jóval alacsonyabb arányban mondták ezt (66,7\%). A nevelőim többsége elfogad olyannak, amilyen vagyok állítással is magasabb arányban értettek teljesen egyet vagy egyet a lakásotthon lakói (80,7\%), mint a gyermekotthonban élők $(68,2 \%)$.

A lakásotthonban élők többen érzik úgy, hogy a velük foglalkozó felnőttek segítőkészek. Ennek oka lehet, hogy a lakásotthonban a kisebb gyereklétszám miatt több lehetőség adódik a személyes, közeli kapcsolat kialakítására a felnőtt és a gyerek között.

A nevelőkkel kialakított kapcsolat minősége is több szempontból fontos. Egyrészt a fiatalok számára a nevelőknek mintaadó szerepük van, másrészt a családi támogatást pótolják. A korábbiakban láttuk, hogy a barátok, kortársak szerepe jelentősen megnőtt a gyerekek társas kapcsolati hálójában, de ez nem jelenti azt, hogy nem igénylik a felnőttek segítségét, támogatását. A nevelők tehát a társas támogató rendszer fontos pillérét alkotják.

29. táblázat. Milyen könnyen tudja megbeszélni a problémákat

\begin{tabular}{|l|c|c|c|c|}
\hline \multirow{2}{*}{$\begin{array}{l}\text { Problémák } \\
\text { megbeszélése }\end{array}$} & \multicolumn{2}{|c|}{ Gyermekotthon } & \multicolumn{2}{c|}{ Lakásotthon } \\
\cline { 2 - 5 } Nagyon könnyen & $\mathbf{N}$ & $\mathbf{\%}$ & $\mathbf{N}$ & $\mathbf{\%}$ \\
\hline Könnyen & 17 & 25,8 & 10 & 17,5 \\
\hline Nehezen & 29 & 43,9 & 29 & 50,9 \\
\hline Nagyon nehezen & 11 & 16,7 & 13 & 22,8 \\
\hline Nem válaszolt & 2 & 10,6 & 5 & 8,8 \\
\hline Összesen & 66 & 3,0 & - & - \\
\hline
\end{tabular}

A 29. táblázat adatai alapján megállapítható, hogy arra a kérdésre milyen könynyen tudják megbeszélni a problémáikat a gyerekek a nevelökkel, többségük $(69,2 \%)$ úgy válaszolt, hogy nagyon könnyen vagy könnyen meg tudja beszélni a problémáit.

A gyermekotthont és a lakásotthont összehasonlítva nem találtunk különbséget a két intézmény között. Mind a gyermekotthonban élők többsége (69,7\%), mind a lakásotthonban élők többsége $(68,4 \%)$ azt válaszolta, hogy nagyon könnyen vagy könnyen meg tudja beszélni a problémáit a nevelőkkel.

A gyermekotthonban dolgozó felnőttekkel ugyanúgy meg tudják beszélni a problémáikat a gyerekek, mint lakásotthonban élő társaik. Ebből arra következtetünk, hogy a magas gyermeklétszám, a kedvezőtlenebb tárgyi feltételek ellenére is a gyermekotthonban dolgozók törekednek arra, hogy a rájuk bízott gyerekek 
segítségére legyenek. A nevelőkkel való probléma megbeszélésnek azért is nagy jelentősége van a gyerekek életében, mert a családi kapcsolatok elemzésénél egyértelmủen láttuk, hogy a gyerekek többsége nem tudja a szüleivel a problémáit megbeszélni. Összefoglalva megállapítható, hogy az intézményi környezettel a gyerekek többsége elégedett.

12. ábra. Az intézményben élö fiatalok elégedettsége jelenlegi életükkel

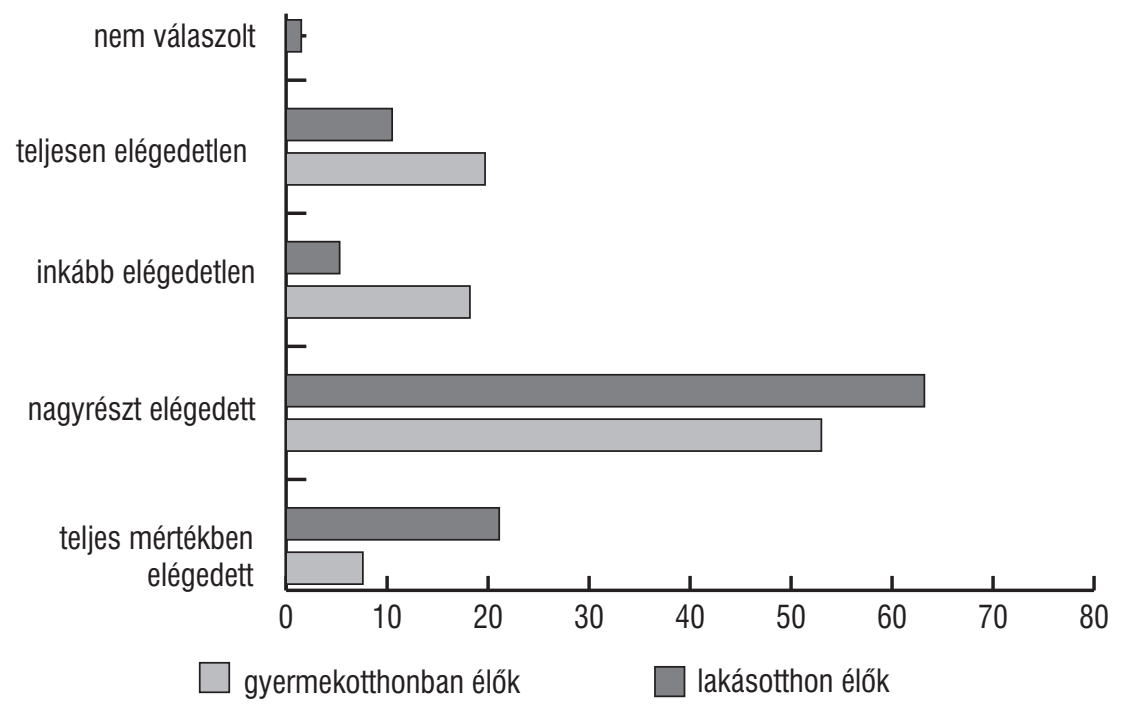

A fiatalok elégedettségét támasztja alá az is, hogy arra a kérdésre, mennyire elégedett mostani életével, többségük azt válaszolta, hogy nagyrészt elégedett. A 12. ábra alapján megállapítható, hogy a gyermekotthonban élők $53 \%$-a, a lakásotthonban élőknek pedig a 63,2\%-a nagyrészt elégedett az életével. (16. ábra) Az adatokból az is jól látszik, hogy a lakásotthonokban élók elégedettebbek az életükkel, mint a gyermekotthonban élö társaik. A teljes mértékben elégedettek lényegesen többen vannak a lakásotthonban $(21,1 \%)$, mint a gyermekotthonban $(7,6 \%)$.

Összehasonlítva az Örkényi és munkatársai (2005) által kapott eredményekkel, a fiatalok intézeti környezettel való elégedettségére vonatkozóan azt tapasztalták, hogy a fiatalok közel fele úgy gondolja bevonják őket a róluk szóló döntésekbe, bár közel harmaduk jelezte, hogy attól függ, miről van szó. Ez az arány az általunk megkérdezettek között is jellemzö. A gyermekotthonban élők magasabb arányban számoltak be arról, hogy részesültek már rosszabb bánásmódban, mint társaik. Ez egybeesik saját eredményeinkkel. A két otthontípus között az országos vizsgálat- 
ban nem találtak különbséget a nevelőtanárral való probléma- megbeszélésben, ahogy mi sem.

Zsámbéki (2004) vizsgálatában szintén arra a megállapításra jutott, hogy a lakásotthonban élő gyerekeknek 81,8 \%-a elégedett az elhelyezési körülményeivel.

Elekes-Paksi (2005) pedig úgy találta, hogy a gyermekotthonban élők körében egyértelmüen a baráti kapcsolatok jelentik a legfőbb elégedettségi forrást a gyerekek számára.

Összefoglalva megállapítható, hogy a lakásotthonban élő fiatalok elégedettebbek az elhelyezési körülményeikkel, mint a gyermekotthonban élő társaik. Az elégedettségükhöz a tárgyi feltételek színvonala, a velük való bánásmód, a társaikkal, a nevelőikkel való kapcsolat is hozzájárult. Az elégedettséget növeli továbbá az is, hogy nagyobb részük úgy ítéli meg, bevonják őket a róluk szóló döntésekbe. Az adatok szerint az otthonokban folyó élet szereplői közül mind a gyerektársak, mind a nevelők többsége elfogadó és segítőkész. A lakásotthonban élők nagyobb elégedettségének mutatója az is, hogy kevesebbszer szöktek meg a fiatalok innen, mint a gyermekotthonokból.

\section{Jövöterv}

Az általános és középiskolás fiatalok jövőre vonatkozó elképzeléseit vizsgálta a '80-as években és húsz évvel később H. Sas Judit (2002). A két kutatás lényeges eltérést mutat a fiatalok jövőtervére vonatkozóan. Az élet legfontosabb területeinek és értékeinek egymáshoz viszonyított aránya és tartalma változóban van. (H. Sas, 2002). A korábbi kutatásban közel minden harmadik-negyedik gyerek dolgozata több mint 60 százalékában a jövőbeni családjáról fogalmazta meg a vágyait, terveit, elképzeléseit. A későbbi írások tanúsága szerint mindössze a gyerekek 5,5\%-a, azaz összesen minden 20. gyerek gondolkodott a családról. Az írások nagyobb részében (65\%) azt fogalmazták meg, hogy milyen iskolai végzettséget képzelnek el maguknak. Előtérbe került az iskolai pályafutás. A leírt élettervekben szemben a régi kutatás adataival, most a jövőbeni pályára, hivatásra, az ehhez vezető útra, a felsőfokú egyetemi továbbtanulásra tevődött át a tervek hangsúlya. A tervek horizontján sokkal nagyobb teret tölt ki a továbbtanulás, a munka, a karrier, mint a család. (H. Sas, 2002)

Hasonló eredményt fogalmaznak meg az Ifjúság 2004 kutatás adatai. A fiatalok számára legfontosabb az iskolai életpálya, ezt követi második helyen a lakáshoz jutás, majd harmadik helyen a családalapítás. Az élettervek megvalósulásának esélyeit tekintve a fiatalok optimisták.

Az általunk megkérdezett fiatalok arra a kérdésre, hogy hogyan képzelik el az életüket tíz év múlva, rövid, felsorolás jellegü válaszokat adtak. Amit szeretnének elérni, az a család, a munka, a ház. A legtöbben első helyen a családot jelölték meg, amivel elképzelésük szerint 10 év múlva rendelkezni fognak. A családot, a munka, 
majd a saját ház követte a sorrendben. Néhány jellemző válasz: „Egy családban élek a gyerekeimmel és dolgozom",

„Szeretném, ha tíz év múlva lenne családom, egy gyereket szeretnék, nyugodt környezetben szeretnék élni. Szeretném, ha lenne egy biztos munkahelyem, hogy a gyerekeimet tudjam nevelni.”, „Családot szeretnék, munkát és gondoskodó férjet”

„Boldog párkapcsolatban, két szép egészséges gyermekkel, normális életkörülmények között szeretnék élni."

$\mathrm{Az}$ adatokat összevetve szembetűnő az a különbség, hogy az intézményben élő fiatalok az iskolai életpályát meg sem említik az elérendő célok között, míg az országos kutatásban a fiatalok előkelő helyre teszik az iskolai végzettséget és a hozzá kapcsolódó célokat. Mindez az intézményben élö fiatalok távlatokban való gondolkodásának a hiányosságára utal. Hiszen a magasabb iskolai végzettség megszerzése javíthatja a munkába állás lehetőségét, ez pedig a lakhatási feltételek megteremtését befolyásolhatja. A gazdagságot, pénzt az általunk megkérdezett gyerekek közül csak hárman jelölték meg. Olyan javakat, mint pl. az autó szintén nagyon kevesen (hét fö) jelöltek meg, amit a jövőben szeretnének birtokolni. Kevesen nyilatkoztak úgy, hogy nem tudják, mi lesz tíz év múlva, mindössze a gyerekek 12,1\%-a. Az adatok alapján jól látszik, hogy a fiatalok többsége konkrét elképzeléssel rendelkezik a jövőbeni céljaira vonatkozóan. Pesszimista válasz szinte alig akadt, mindössze hárman mondták azt, hogy munkanélküliek lesznek, illetve minimálbért fognak kapni. Az adatok alapján megállapítható, hogy az általunk megkérdezett fiatalok jövőre vonatkozó tervei lényegesen eltérnek a fiatalok átlagától. A továbbtanulási tervek meg sem jelennek a jövőre vonatkozó elképzelésekben. A tervekben legnagyobb hangsúlyt a család kap, ami a fiatalokra általában húsz évvel ezelőtt volt jellemző. A gyerekek perspektivikus helyzetmegítélése optimista. Az is megállapítható, hogy az elképzeléseikben tükröződik az értékrendjük, mivel az életterveik között első helyen a család utáni vágy jelenik meg, mint ahogyan az általuk fontosnak tartott értékek között is elökelö helyen szerepel a család. 


\section{6. ÖSSZEGZÉS}

A kérdőíves vizsgálat eredményeinek elemzésekor arra a kérdésre kerestük a választ, hogy az elhelyezési lehetőségek változásával hogyan alakultak a gyermekvédelmi intézményben élő gyerekek életkörülményei, milyen előnyei/hátrányai vannak a különböző típusú intézményi elhelyezésnek. Célunk az volt, hogy a gyermekotthoni és a lakásotthoni elhelyezést összehasonlítva feltárjuk a gyermekotthonban és a lakásotthonban elhelyezett gyerekek életkörülményei közötti különbségeket.

Az alábbiakban a hipotéziseinkre vonatkozóan a következő összefoglaló megállapításokat tesszük: az első hipotézisünk szerint a lakásotthonban élő gyerekek gazdagabb társas kapcsolattal rendelkeznek, mint gyermekotthonban élő társaik. Ez a feltételezés csak részben igazolódott. A kapott adataink alapján megállapítható, hogy mindkét intézménytípusban gazdag társas kapcsolatokkal rendelkeznek a gyerekek, a lakásotthon lakói között többen vannak olyanok, akik három vagy több baráttal rendelkeznek, valamint a lakásotthon lakóira inkább jellemzö, hogy meghívják a barátaikat az otthonukba. A gyermekotthon lakói viszont a barátokkal töltött idö tartamát tekintve több idöt töltenek barátaikkal, mint a lakásotthonban élő társaik. Korábban azt gondoltuk, hogy az intézményben élő gyerekek elsősorban intézményben élő társaikkal kötnek barátságot. Eredményeink szerint azonban mind a gyermekotthonban, mind a lakásotthonban élő gyerekek több mint felének családban él a barátja. Ez arra utal, hogy a fiatalok nem elszigetelten, csak az intézményben élö társaikkal barátkoznak, hanem családban élő kortársaikkal is. Ez segítheti őket abban, hogy családi mintákat ismerjenek meg. A fentiek alapján megállapítható, hogy a vizsgált gyerekek/fiatalok körében a társas kapcsolatokat tekintve a testvérekkel való kapcsolat mellett a baráti kapcsolatok is igen jelentősek. A társas támogatás fontos szereplői a barátok. Ez hatással van a gyerekek életkörülményeinek alakulására, mivel többségük könnyen vagy nagyon könnyen meg tudja beszélni a problémáit a barátaival, illetve a szabadidő eltöltésében is jelentős szerepük van. A baráti kapcsolatok kiemelt jelentőségét támasztja alá az a megállapításunk is, hogy a gyerekek értékpreferenciái között előkelő helyen szerepel a családi biztonság, de a baráti kapcsolat mint fontos érték megelözi azt. A barátság fontosságát maga a vizsgált korosztály is indokolja, hiszen a serdülőkorban a kortárskapcsolatok felerősödnek, a gyerekek számára mintaként szolgálnak.

A második hipotézis, hogy az általunk vizsgált lakásotthonokban élö fiatalok kevesebben próbálták ki és használták a drogot, az alkoholt, valamint kevesebben dohányoznak, mint gyermekotthonban élö társaik. Ezt a hipotézisünket igazolni tudtuk. 
Az alkoholkipróbálás és fogyasztás tekintetében azt tapasztaltuk, hogy a lakásotthonban élők körében alacsonyabb a kipróbálók aránya. Még nagyobb különbséget találtunk a fogyasztás gyakoriságára vonatkozóan. A lakásotthonban élők között a hetente alkoholt fogyasztók aránya jóval alacsonyabb, mint a gyermekotthonban élők körében. A drogok kipróbálása és használata terén ugyanezt tapasztaltuk. Elekes-Paksi (2005) országos vizsgálatához képest alacsonyabb mértékủ kipróbálás és fogyasztás jellemző az általunk megkérdezettek körében. Ez összefügghet a drogfogyasztásban megmutatkozó regionális különbségekkel is. Az Ifjúság kutatások szerint a legnagyobb mértékủ a drog kipróbálása és fogyasztása a közép-magyarországi régióban, a legalacsonyabb pedig az észak-alföldi régióban.

A dohányzást kipróbálók és naponta használók körében is kisebb arányban képviseltetik magukat a lakásotthonban élők. A soha nem dohányzók körében többen vannak a lakásotthon lakói a gyermekotthonban élőkhöz képest.

Összességében a lakásotthonban élők szerhasználati szokásai kedvezőbb képet mutatnak, mint a gyermekotthonban élő társaiké. Ez valószínűleg annak is köszönhető, hogy a lakásotthonban több lehetőség van a személyes kapcsolatok kialakítására, a kisebb gyereklétszám miatt átláthatóbbak a gyerekek mindennapjai. Több más tényező mellett a gyerekek életkörülményei is befolyásolhatják a szerhasználati szokásaikat.

A gyerekek jelenlegi és jövőbeni életkörülményeit is jelentősen befolyásolja az iskolai végzettségük. Feltételeztük, hogy a lakásotthonban élők közül többen tanulnak gimnáziumban és szakközépiskolában, mint a gyermekotthonban élők. Ezt a feltételezést igazolni tudtuk. Az általunk megkérdezettek legnagyobb arányban szakiskolában tanulnak tovább mind a két intézménytípusban, terveik között is elsősorban valamilyen szakma megszerzése szerepel. A gimnáziumi és szakközépiskolai továbbtanulás azonban lényegesen nagyobb arányban jellemző a lakásotthonban élőkre. Különösen igaz ez a szakközépiskolai továbbtanulásra, ahol négyszer többen tanulnak a lakásotthonban élök közül, mint a gyermekotthoni társaik. Az intézményekben élő gyerekek körében gyakori jelenség az osztályismétlés. Ebben is különbséget találtunk a két intézmény között. A gyermekotthonban élők között jóval alacsonyabb az életkoruknak megfelelő évfolyamon tanulók aránya, mint a lakásotthonban élőknél. Az iskolázottságra vonatkozó jobb lakásotthoni eredmények összefügghetnek a tanulásra fordított idő mennyiségével is. Adataink szerint a lakásotthonban élök több időt töltenek tanulással, mint gyermekotthoni társaik. Elgondolkodtató ugyanakkor, hogy az intézményben élö fiatalok a jövőre vonatkozó terveik között elérendő célként az iskolai tanulmányokat meg sem említik.

A gyerekek elégedettségére vonatkozóan azt feltételeztük, hogy az általunk vizsgált lakásotthonokban élők elégedettebbek az életkörülményeikkel, a velük való bánásmóddal és közöttük többen vannak olyanok, akik könnyen meg tudják beszélni a problémáikat a nevelőikkel, mint a gyermekotthonban élő társaik. 
Ezeket a feltevéseket igazolni tudtuk. A lakásotthonban/gyermekotthonban élők elégedettségét több szempontból is vizsgáltuk, ami a következő eredményeket mutatta. A lakásotthonban élők az otthonnal, annak tárgyi feltételeivel elégedettebbek. Többen értékelték ötös osztályzattal az otthont, mint a gyermekotthonban élők. A lakásotthonban élők - a gyermekotthon lakóihoz viszonyítva - magasabb arányban számoltak be arról, hogy bevonják őket a róluk szóló döntésekbe, és nem bánnak velük rosszabbul, mint a társaikkal. A fiatalok elégedettségét tükrözi az is, hogy a lakásotthonban alacsonyabb a szökések száma, mint a gyermekotthonban élők körében. Ezt a megállapítást az intézményvezetőkkel készült interjúk is alátámasztják. A gyerekek életkörülményeit jelentősen befolyásolja az ott dolgozó szakemberekkel és a gyerektársakkal való kapcsolatuk. A lakásotthonban élők mind a társaikat, mind a nevelöiket nagyobb arányban tartják segítőkésznek és elfogadónak, mint a gyermekotthonban élők. A lakásotthonban élők könnyen meg tudják beszélni problémáikat nevelöikkel, de ez igaz a gyermekotthonban élőkre is. Korábban azt gondoltuk, hogy a gyermekotthonban a nagyobb létszám miatt kevesebb lehetőség nyílik a problémák megbeszélésére, de ebben nem találtunk lényeges különbséget az intézmények között. A lakásotthonban élö teljesen elégedett fiatalok aránya háromszorosa a gyermekotthonban élő teljesen elégedett fiatalokhoz képest.

A szabadidő eltöltésére vonatkozóan azt feltételeztük, hogy a lakásotthonban élő fiatalok szabadidejükben több kulturálódásra alkalmas programban (színház, mozi, hangverseny, múzeum stb.) vesznek részt, mint gyermekotthonban élö társaik. Ezt a hipotézist csak részben tudtuk igazolni. Az intézmények látogatásának gyakoriságát vizsgálva szignifikáns különbséget találtunk a színház, a mozi, a könyvtár, a koncert, a kocsma látogatását tekintve a gyermekotthon és a lakásotthon lakói között. A kapott eredmények szerint a lakásotthonban élök körében gyakoribb a mozi-, színház- és koncertlátogatás. A gyermekotthon lakói között a könyvtár és a kocsma látogatása gyakoribb. Összességében azonban a kulturális intézményeket ritkán látogatják az általunk megkérdezettek. A legtöbb időt tévézéssel és zenehallgatással töltik a növendékek mindkét otthontípusban. A szabadidő eltöltésére vonatkozóan az intézmények között nem találtunk lényeges különbséget. Ebben a vonatkozásban lényegesen nem jobbak a lakásotthonban élő gyerekek körülményei.

A szabadidőre vonatkozó másik feltételezésünk szerint az általunk megkérdezett lakásotthonban élő fiatalok aktívabbak, több szabadidős programban vesznek részt, mint gyermekotthonban élö társaik.

Elekes és Paksi (2005) kutatásában arra az eredményre jutott, hogy az intézményekben élők az átlagnál gyakrabban töltik az idejüket „otthonülős” programokkal. Hipotézisünket, miszerint a lakásotthonban élők több programban vesznek részt, szabadidejüket tartalmasabban töltik, mint gyermekotthoni társaik, csak részben tudtuk igazolni. Mind a lakásotthonban, mind a gyermekotthonokban elsősorban 
az otthonban és barátok körében töltik a fiatalok a szabadidejüket. Tehát rájuk is jellemző az „otthonülős” program. A gyermekotthonok és a lakásotthonok között különbséget a sportolásban, a kirándulásokon való részvételben találtunk. A lakásotthonban élők több időt töltenek sportolással, valamint aktívabban szerveznek saját maguknak szabadidős programokat. Ebből arra következtetünk, hogy önállóbb életet élnek, több lehetőséget kapnak az önálló élet szervezésére, így közvetlenül is részt vesznek az életkörülményeik javításában.

A kutatásunkban nem volt célunk a gyermekotthonban/lakásotthonban élő cigány gyerekekkel külön foglalkozni. Ezt mégis meg kellett tennünk, mivel a megkérdezett gyerekek közel fele cigánynak vallotta magát. Fontosnak tartjuk megemlíteni azt a tapasztalatunkat, hogy a gyermekotthonban/lakásotthonban élő cigány gyerekek szinte az általunk vizsgált valamennyi területen rosszabb mutatókkal rendelkeznek nem cigány társaiknál. Ezek a következők. A kedvezőtlenebb elhelyezési körülményeket nyújtó gyermekotthonban több cigány gyermek él, mint a lakásotthonokban. Társas kapcsolataikat tekintve több baráttal rendelkeznek, és problémáikat is nagyobb részben tudják velük megbeszélni, mint nem cigány társaik. Lényeges vonása azonban a társas kapcsolataiknak, hogy barátaik elsősorban a gyermekotthonban élő társaik közül valók, kevesebb családban élő barátjuk van, mint nem cigány társaiknak. Szabadidejüket többen töltik az otthonban, barátaik körében, ami erősíti az egymás közötti zártabb kapcsolatrendszert. Szerhasználati szokásaikat vizsgálva azt találtuk, hogy mind az alkoholfogyasztás, mind pedig a dohányzás és a drogfogyasztás is magasabb arányban jellemzi öket, mint nem cigány társaikat. Az iskolai tanulmányokra vonatkozóan eredményeink azt mutatják, hogy több a túlkoros közöttük. Gimnáziumi, szakközépiskolai tanulmányokat jóval kisebb arányban folytatnak, mint nem cigány társaik. Továbbtanulási terveikben többen terveznek csak általános iskolai végzettséget, mint nem cigány társaik. Kutatásunk alapján megállapítható, hogy az intézményben élő cigány gyerekek helyzete kedvezőtlenebb a nem cigány társaikhoz képest. Az intézménybe bekerülők között mindenki hátrányos helyzetü, de a kapott eredmények azt mutatják, hogy a gyermekvédelmi intézmények a hátrányokat nem képesek megszüntetni. Ezek a megállapítások számos kérdést vetnek fel, amikre további kutatásokkal lehetne választ adni.

Kutatásunk eredményei hozzájárulnak a gyermekvédelemhez kapcsolódó elméleti ismeretek bővüléséhez. Az elméleti fejezetek kidolgozása során a téma sajátosságából fakadóan törekedtünk az interdiszciplinaritásra. Felhasználtuk a különböző tudományterületek, a szociológia, a neveléstudomány, a szociálpolitika, kutatási eredményeit. Az első fejezetben a gyermekvédelmi intézményekben megvalósuló szocializáció folyamatát, az intézményt mint szocializációs ágenst mutattuk be.

Az intézmények funkcióit többféle megközelítésből áttekintve megállapítottuk, hogy elsősorban a szocializáció, a védelem, a kompenzálás és az önálló életre való 
felkészítés a fő feladatuk. A fejezetben bemutatott ökológiai modellt L. Palareti és C. Berti (2009) alkalmazta először a gyermekotthonokra, lakásotthonokra vonatkozóan. Ennek jelentősége abban áll, hogy segíti az intézményekben megvalósuló szocializációs folyamat értelmezését, amelyet a nemzetközi szakirodalom is csak „black box" jelenségnek nevez.

A nemzetközi kitekintésben a nyugat-európai országok és a kelet-közép-európai országok gyermekvédelmét részletesen elemeztük, áttekintettük, hogy milyen sajátosságokat mutat az egyes országokban a gyermekek intézményes elhelyezése. Az összehasonlító elemzés során azt vizsgáltuk, hogy milyen elhelyezési lehetőségeket - ezen keresztül milyen életkörülményeket- biztosítanak az egyes országokban a család nélkül felnövő gyerekek számára. Az egyes európai országok gyermekvédelmét meghatározott szempontok alapján mutattuk be. Ez abban segítette munkánkat, hogy áttekinthettük a gyermekvédelem lehetséges fejlődési útjait, különböző modelleket ismerhettünk meg. A nyugat-európai országok gyermekvédelmét áttekintve megállapítható, hogy - a kelet-közép-európai országokhoz képest- sokkal korábban és szélesebb körben vezették be azokat a szolgáltatásokat, amelyek a családok támogatására, segítésére irányultak. Ezzel is próbálták megelózni a gyerekek családból való kikerülését. Jóval korábbra tehető azoknak az intézményeknek az átalakítása is, amelyek a családból kiemelt gyerekek elhelyezésre szolgáltak.

Megállapítható továbbá, hogy a nyugat-európai országok modellként szolgáltak a kelet-közép-európai országok számára a gyermekvédelmi intézmények átalakításában.

A harmadik fejezetben a gyerekek elhelyezési lehetőségeinek összehasonlító elemzésére került sor, az 1997. évi XXXI. Gyermekvédelmi törvény bevezetése előtti és utáni időszakban. Megállapítható, hogy a gyerekek életkörülményei jelentősen javultak a törvény bevezetése után. A javulás több területen is megnyilvánul. A gyerekek elhelyezésében vezető szempont lett a családias körülmények biztosítása. A statisztikai adatok elemzése során megállapítottuk, hogy több gyermek él lakásotthonban, mint gyermekotthonban, és a gyermekotthonokban is törekedtek kisebb létszámú csoportok létrehozására. A gyerekek életkörülményeinek javítását szolgálja az új intézmények létrehozása. A különleges, a speciális és az utógondozó otthonok korszerübb tartalommal müködnek, mint a korábbi években. A gyermekek életkörülményeinek javulásához hosszabb távon az is hozzájárul, hogy a középfokú oktatási intézményekben többen tanulnak tovább, mint a korábbi években.

A negyedik fejezetben hazai, empírikus vizsgálatokat és azok eredményeit foglaltuk össze, amelyek az intézményekben élő gyerekek életkörülményeivel foglalkoznak.

Így az elhelyezési körülményekre, a szabadidő eltöltésére, iskolázottságra, a gyerekek alkohol-, drog- és dohányzási szokásaira vonatkozó kutatásokat tekin- 
tettük át. A fejezet egy részében a hazaihoz tematikusan kapcsolódó nemzetközi kutatásokat mutattuk be, amelyek az intézményben élő gyerekek problémáit tárják fel a különböző országokban. A kutatások áttekintése több szempontból is segítette a munkánkat.

Egyrészt a megfelelő kutatási módszerek kiválasztásában segített, másrészt a kérdőíves vizsgálat megalapozását szolgálta. Továbbá lehetővé tette azt is, hogy saját kutatási eredményeinket elemezni tudjuk, összevethessük más kutatások eredményeivel.

Az ötödik fejezetben a Hajdú-Bihar megyében múködő gyermekotthonokban és lakásotthonokban, valamint a benne élő gyerekek körében végzett kérdöíves vizsgálat eredményeit foglaltuk össze. A kérdőívek elemzése alapján megállapítható, hogy a lakásotthoni elhelyezés kedvezőbb életkörülményeket biztosít a gyerekek számára, mint a gyermekotthoni elhelyezés. A lakásotthonban élő gyerekek jobb tárgyi feltételek között élnek, mint gyermekotthoni társaik.

Az életkörülményeket jelentősen befolyásoló szabadidős tevékenységek hasonlóak a két intézménytípusban, az intézmények átalakítása a szabadidős tevékenységeket lényegesen nem befolyásolta. A lakásotthonban élők ugyanakkor aktívabban szervezik saját szabadidős programjaikat, így maguk is hozzájárulnak életkörülményeik javításához.

Tanulmányaikra vonatkozóan megállapítható, hogy a lakásotthonban élők közül többen tanulnak gimnáziumban és szakközépiskolában, mint a gyermekotthonban élők. Tanulmányi mutatóik a tekintetben is jobbak, hogy kevesebb a túlkoros gyerek közöttük, valamint több időt fordítanak tanulásra. Értékválasztásaikat vizsgálva az látszik, hogy a lakásotthonban élők számára a materiális értékek kevésbé fontosak, mint gyermekotthoni társaiknak. Az alkoholt, drogot, dohányzást kipróbálók és fogyasztók aránya alacsonyabb a lakásotthonokban, mint a gyermekotthonokban. A lakásotthonok előnye a gyerekek elégedettségében is megmutatkozik. Az elhelyezéssel teljesen elégedettek háromszor többen vannak a lakásotthonokban, mint a gyermekotthonokban.

Összefoglalva megállapítható, hogy az intézményben élő gyerekek életkörülményei javultak az elmúlt években bekövetkezett változások révén, de a gyerekek legkiszolgáltatottabb csoportjainak esélyegyenlőségét a gyermekvédelmi intézmények sem tudják megvalósítani. A gyermekvédelmi problémák társadalmi okokra vezethetők vissza, így a megoldást is elsősorban ott kell keresni, az intézmények ebben legfeljebb közvetítő szerepet tölthetnek be. 


\section{FELHASZNÁLT IRODALOM}

Albert Fruzsina-Dávid Beáta (2007): Embert barátjáról. A barátság szociológiája. Budapest, Századvég Kiadó

Albert Fruzsina-Dávid Beáta (1999): Az emberi kapcsolatok alakulása Magyarországon a XX. század utolsó évtizedeiben In Szívós Péter-Tóth István György (szerk.): A bizalmas kapcsolatokról. Budapest, TÁRKI 218-230.

Andorka Rudolf (2006): Bevezetés a szociológiába. Budapest, Osiris

Arató Domonkos-Csizmadia Sándor-Szabó Erzsébet (2002): Nevelöotthon típusok összehasonlitó vizsgálata. www.fernevtan.hu 2008. 06. 02.

Bauer Béla-Szabó Andrea (2005)(szerk.): Ifjúság 2004 Gyorsjelentés. www. ncsszi.hu/download.php?file_id $=418 \mid 2013.02 .10$.

Benedek István (1997): Kollégiumi neveléstan. (A kollégiumi neveléselmélete és gyakorlata). Budapest, Országos Közoktatási Intézet.

Bourdieu P., (1978): A társadalmi egyenlötlenségek újratermelödése. Budapest, Gondolat.

Bronfenbrenner (1992) Ecological systems theory. In Vasta R. (ed.): Annals of child development Six Theories of Child Development: Revised Formulations and Current Issues, London, Jessica Kingsley

Browne K. - Hamilton C. - Johnson R. - Chou S. (2005): Young Children in Institutional care in Europe. Early Childhood Matters 105. dec. 2005. 15-19.

Bukodi Erzsébet (2002): Ki, mikor, kivel (nem) házasodik? Párválasztás Magyarországon. Szociológiai Szemle, 2. sz. 28-58.

Bukodi Erzsébet (2005): Partnerszelekció házasságon belül és kívül. Demográfia, 48. 2-3.sz. 218-253.

Büki Péter (2004): Gyermekvédelem és gyógypedagógia. In Domszky András (szerk.): Gyermekvédelmi szakellátás. Budapest, Nemzeti Család- és Szociálpolitikai Intézet

Büki Péter (2004): A gyermekvédelmi szakellátás formái és tartalma. In Domszky András (szerk.): Gyermekvédelmi szakellátás. Budapest, Nemzeti Család- és Szociálpolitikai Intézet

Carter D., (2005): Family Matters: A study of institutional childcare in Central and Eastern Europe and the Former Soviet Union. Every Child, London.

Cseh-Szombathy László (1985): A házastársi konfliktusok szociológiája. Budapest, Gondolat.

Cseh-Szombathy László (1979): Családszociológiai problémák és módszerek. Budapest, Gondolat.

Cseh-Szombathy László-Ferge Zsuzsa (1968): A szociológiai felvétel módszerei. Budapest, Közgazdasági és Jogi Könyvkiadó. 
Csepeli György (1997): Szociálpszichológia. Budapest, Osiris

Csókay László (1995): A gyermekvédelem gyakorlata Németországban. In Csókay László-Domszky András-Hazai Vera-Herczog Mária (szerk.): A gyermekvédelem nemzetközi gyakorlata. Budapest, Pont Kiadó

Dobos László (1986): A nevelőotthonok helye és szerepe a gyermekvédelemben az elmúlt évtizedekben és napjaink tennivalói. Gyermek- és ifjúságvédelem. 5. 1. sz. 71-75.

Dobos László (szerk.) (1985): Magyarországi bentlakásos gyermek- és ifjúságvédelmi intézmények. Budapest, Müvelődési Minisztérium

Domszky András (1985): A nevelöotthoni nevelés programja I. Budapest, OPI

Domszky András (2004): A gyermekvédelmi szakellátás értékháttere a szakellátás alapértékeinek érvényesülését szolgáló biztosítékok, technikák In Domszky András (szerk.): Gyermekvédelmi szakellátás. Budapest, NCSSZI

Domszky András (2003): Gyermekotthonok szakmai program rendszerszemléletü kialakitása Budapest, NCSSZI CD

Domszky András (1999): A gyermekotthonok müködésének szabályairól és szakmai követelményeiről. Budapest, Országos Család- és Gyermekvédelmi Intézet

Domszky András (1987): A szervezetközpontú neveléstől a nevelésközpontú szervezet felé (1.) Gyermek és ifjúságvédelem, 6. 2. sz. 1-11.

Domszky András (1994): A gyermek- és ifjúságvédelem rendszere Magyarországon. In Csókay László, Domszky András, Hazai Vera-Herczog Mária (szerk.): A gyermekvédelem nemzetközi gyakorlata. Budapest, Pont Kiadó

Domszky András - Büki Péter (2001): Gyermekvédelem és gyógypedagógia. Educatio, 10. 2. sz. 296-311.

Elekes Zsuzsanna-Paksi Borbála (2005): A gyermekvédelmi gondoskodásban részesülö fiatalok alkohol és egyéb drogfogyasztása. Kapocs, 4. 20. sz. 2-22.

Ferge Zsuzsa (1976). Az iskolarendszer és az iskolai tudás társadalmi meghatározottsága. Budapest, Akadémiai Kiadó

Ford T-Vostanis P.-Meltzer H.-Goodman R. (2007): Psychiatric disorder among British children looked after by local authorities: comparison with children living in private households. The British Journal of Psichiatry, 190. 319-325.

Frommann - Haag - Trede (1991): Residential Education in the Federal Republic of Germany In Gottesmann (eds.): Residential Child Care An international reader. London, Whiting \& Birch LTD

Giddens, A. (1997): Szociológia. Budapest, Osiris

Gilligan R. (1999): Enhancing the resilience of children and young people in public care by mentoring their talents and interests. Child and Family Social Work, 4. 187-196.

Goslin D.A. (1976): Bevezetés a szocializáció kutatásába. In Pataki Ferenc (szerk.): Pedagógiai szociálpszichológia. Budapest, Gondolat Kiadó 
Gudbrandsson (2004): Children in institutions: prevention and alternative care. http://www.crin.org/bcn/details.asp?id=9316\&themeID=1003\&topicID=1023 2012. 10. 13.

Hanák Katalin (1985): A volt állami gondozottak társadalmi beilleszkedése In Kósáné Ormai Vera, Münnich Iván (szerk.): Szocializációs zavarok-beilleszkedési nehézségek. Budapest, Tankönyvkiadó

Hanák Katalin (1978): Társadalom és gyermekvédelem. Budapest, Akadémia Hatvani Erzsébet-Papházi Tibor (2004): Deviancia és szociális fogyatékosság. A javítóintézetekből elbocsátottak után követéses vizsgálatának lehetőségei, tapasztalatai In Papházi Tibor (szerk.): Javitóintézet, család, gyermekvédelem. Budapest, NCSSZI

Havas-Herczog-Neményi (2007): Fenntartott érdektelenség. Roma gyermekek a magyar gyermekvédelmi rendszerben. Kutatási beszámoló Európai Roma Jogok Központja www.errc.org/cms/upload/media/02/90/m00000290.pdf2013. 02. 15.

Hazai Istvánné-Csókay László (1990): Állami gondozott gyerekek és fiatalok iskoláztatásának helyzete. Gyermek- és ifjúságvédelem, 9. 3. sz. 10-19.

Hazai Vera-Volentics Anna (1986): Sajátos élethelyzet-sajátos életmód Nevelöotthoni életmód egy időmérleg- vizsgálat tükrében. Pedagógiai Szemle, 36. 3. sz. 219-230.

Hazai Vera (1984): Nevelőotthoni csoportok szociometriai vizsgálata. Gyermekés ifjúságvédelem, 3. 3. sz. 9-19.

Hazai Vera (1994): A gyermekvédelem gyakorlata Hollandiában. In Csókay László-Domszky András-Hazai Vera-Herczog Mária (szerk.): A gyermekvédelem nemzetközi gyakorlata. Budapest, Pont Kiadó

Hellinckx W. (2002): Residential care: Last resort or vital link in child welfare? International Journal of Child \& Family Welfare, 5. Number 3. 75-84.

Herczog Mária (1995): A nevelőszülő helye és szerepe a gyermekvédelemben. Esély, 6. 2. sz. 82-100.

Herczog Mária (1997): A gyermekvédelem dilemmái. Budapest, Pont Kiadó Herczog Mária (2001): Gyermekvédelmi kézikönyv. Budapest, Kjk. Kerszöv

Herczog Mária (1994): A gyermekvédelem gyakorlata Nagy-Britanniában. In Csókay László - Domszky András - Hazai Vera - Herczog Mária (szerk.): A gyermekvédelem nemzetközi gyakorlata. Budapest, Pont Kiadó

Herczog Mária (2002): Együtt vagy külön? Budapest, KjK Kerszöv

Herczog Mária (2007) Gyermekbántalmazás. Budapest, Complex Kiadó

Herczog Mária-Neményi Mária (2007): Roma gyerekek a gyermekvédelemben. Család, gyermek, ifjúság, 16. 6. sz. 6-12.

Hodosán Róza-Rácz Andrea (2009): Szakmai képzésben részesülő gyermekvédelmi szakellátásban élő fiatalok iskolai pályafutásának vizsgálata. Család, Gyermek, Ifjúság 18. 4. sz. 14-25. 
Hrdlickova (1991): Residential Care and Education. In Czechoslovákia In Gottesmann (eds.) Residential Child Care An international reader. London, Whiting \& Birch LTD

H. Sas Judit (2002): Egy napod tíz év múlva. Educatio, 11. 3. sz. 365-383.

Kahan B., (1991): Residential care and Education. In Great Britain In Gottesmann (eds): Residential Child Care An international reader. London, Whiting \& Birch LTD

Kamarás Ferenc (2001): A termékenység alakulása és befolyásoló tényezői. In Cseh-Szombathy László-Tóth Pál Péter (szerk.): Népesedés és népességpolitika. Budapest, Századvég

Kerezsi Klára (1995): A védtelen gyermek (Eröszak és elhanyagolás a családban). Budapest, Közgazdasági és Jogi Könyvkiadó

Kiss Gabriella (2004): A szabadidő szociológia legújabb trendjei és aktuális problémái. In Kiss Gabriella-Csoba Judit-Czibere Ibolya (szerk.): Idővonat. Tanulmányok a társadalomtudományok köréböl. Debrecen, Kossuth Egyetemi Kiadó

Knorth E. J. (2002): Residential child and youth care in the Netherlands: Developments and challenges. International Journal of Child \& Family Welfare, 5. Number 3. 84-96.

Kozma Tamás (1999): Bevezetés a nevelésszociológiába. Budapest, Nemzeti Tankönyvkiadó

Kruszko K. (1991): Residential child Care in the Republic of Poland. In Gottesmann (eds): Residential Child Care An international reader. London, Whiting \& Birch LTD

Kulcsár Kálmán (1969): Az ember és társadalmi környezete. Budapest, Gondolat Lambert R.-Bullock R.-Millham S. (1974): Az iskolaszociológia kézikönyve. In Ferge Zsuzsa, Háber Judit (szerk.): Az iskola szociológiai problémái. Budapest, Közgazdasági és Jogi Könyvkiadó

Ligthart L.E.E.-Jhr. Naters J.G. - Keyser F.L.H. (1991): Residential Youth Care and Protection: The Dutch Situation. In Gottesmann (eds): Residential Child Care An international reader. London, Whiting \& Birch LTD

Ligthart L.E.E. (1986): Az ifjúságvédelem a kultúrafogalom változásainak tükrében. Gyermek- és ifjúságvédelem, 5. 3. sz. 46-54.

Liskó Ilona (2008): Szakképzés és lemorzsolódás In Fazekas Károly-Köllő JánosVarga Júlia (szerk.): Zöldkönyv a magyar közoktatás megújitásáért. Budapest, Ecostat

Losonczi Ágnes (1977): Az életmód az időben, a tárgyakban és az értékekben. Budapest, Gondolat Könyvkiadó

Madge N., (1994): Children and residential care in Europe. London, National Children's Bureau

Mead H. (1973): A pszichikum, az én és a társadalom szociálbehaviorista szempontból. Budapest, Gondolat. 
Meltzer H. - Lader D. - Corbin T.-Goodman R. -Ford T. (2004): The mental health of young people looked after by local authorities in Scotland. London, National Statistics

Miltényi Károly-Münnich Iván (1980): Tanulmányok a társadalmi beilleszkedési zavarok köréböl. Budapest, Statisztikai Hivatal Kiadó

Mojzesné Székely Katalin (2002): Ifjúság, hátrányos helyzet, szocializáció- az alapproblémák értelmezése. In Béres Csaba (szerk.): Kirekesztödés vagy integrálódás? Debreceni Egyetem Kossuth Egyetemi Kiadó, Debrecen.

Murányi István (2000): Nevelőotthonban élő fiatalok drogfogyasztása és értéktudata. In Murányi István- Pénzes Mariann- Barát Katalin (szerk.): Drog-CsaládÉrték. Nevelöotthonban élö fiatalok drogfogyasztása és értékrendje. Nyíregyháza, Észak-Kelet-Magyaroszági Szenvedélybetegségeket Megelóző Egyesület 49-85.

Neményi Mária-Messing Vera (2007): Gyermekvédelem és esélyegyenlőség. $\mathrm{Ka}$ pocs, 6. 1. sz. 2-19.

Németh András-Pukánszky Béla (2004): A pedagógia problématörténete. Budapest, Gondolat Kiadó

Ónodi Péter Mihály (2009): A fiatalkorú bünözés okainak vizsgálata a debreceni javitóintézetben. Szakdolgozat. DE Szociológia és Szociálpolitika Tanszék www.dji.hu 2009. 08. 22.

Örkényi Ágota és mtsai (2005): Kutatási beszámoló drogfogyasztás állami gondozott fiatalok körében. Budapest, Országos Gyermek egészségügyi Intézet.

Panduru F. - Pisica S., Molnar M. - Poenaru M. (2006): System in support of children without parental care in Romania Bucharest: National Statistical Institute of Statistics. Country Analytical Report prepared for the MONEE Project. Florence, UNICEF, IRC

Papava V., (1996): Children in difficult Circumstances in Georgia. Report prepared for the MONEE Project. Florence, UNICEF, IRC.

Parsons T. (1966): The Social System. New York, The Free Press

Palareti L. - Berti C., (2009): Different ecological perspectives for evaluating residential care outcomes: Which window for the black box? Children and Youth Services Review, 31. 1080-1085.

Petrie P. - Boddy J., Cameron C., Wigfall C., Simon A. (2006): Working with children in care: European Perspectives. London, Open University Press

Pikó Bettina (2005): Szabadidő és életmód a fiatalok körében. In Pikó Bettina (szerk.): Ifjúság, káros szenvedélyek és egészség a modern társadalomban. Budapest, L'Hartmann

Placintar E. - Olexa M., (2006): System in support of children without parental care in Slovakia. Bratislava: Statistical Office of the Slovak Republic. Country Analitical Report prepared for the MONEE Project, Florence, UNICEF, IRC 
Ploeg J. van der (1986): Heimerziehung in Europa -Kritik und künfüge Gestaltung. In Soisson R. (hrsg.): Aktuelle Probleme Jugendlicher in der Heimerziehung in Europa. Zürich, Fice.

Quinton S., (2004): Stability, permanence, outcomes and support: foster care and adoption compared. Adoption \& Fostering Journal, 28. 4. 6-15.

Rácz Andrea (2006): A gyermekotthoni nevelés kihívásai a nagykorúságuk előtt álló fiatalok jövőképe. Kapocs 5. 4. sz. 14-31.

Roth Mária (1995): Az állami gondozás Romániában 1990 előtt és után. Család, gyermek, ifjúság, 4. 1. sz.. 31-35.

Sas Judit H. (2002): „Egy napom tíz év múlva”. Educatio, 11. 3. sz. 365-383.

Scmid M. - Goldbeck L. - Nuetzel J. - Fegert J. M. (2006): Prevalence of mental disorders among adolescents in Germany youth welfare institutions. www. ncbi.nem.nih.gov/pmc/articles/PMC2262059 2010. 01. 25.

Sinclair I-Gibbs I (1998): Children's Homes: A Study in diversity. Chichester, John Wiley and Sons

Sinclair I-Wilson K-Gibbs I (2001): „A life more ordinary”: what children want from foster placements. Adoption \& Fostering, 25. 4. 17-26.

Solt Ágnes (2007): A gyermekvédelmi gondoskodás rendszerének feltérképezése, müködése és hiányosságai. http://www.okri.hu/content/view/236 2012.11. 10

Somlai Péter-Tóth Olga (2002): A házasság és a család változásai az ezredforduló Magyarországán. Educatio, 11. 3. sz. 339-348.

Somlai Péter (1986): Konfliktus és megértés. Budapest, Gondolat

Somlai Péter (1997): Szocializáció. A kulturális átörökités és a társadalmi beilleszkedés folyamata. Budapest, Corvina

Somlai Péter (2008): Társas és társadalmi. Budapest, Napvilág Kiadó

Stahlmann M. (2000): Betreuungsformen (in) der Heimerziehung. In Kupffer H.Martin K. R. (Hrsg.): Einführung in die Theorie und Praxis der Heimerziehung. Heidelberg, Wiesbaden Quelle und Meyer

Stelmavszk (2002): Residential Care in Poland Past present and future. International Journal of Child \& Family Welfare, 5. Number 3. 102-112.

Strijker P.-Knorth E., J., (2007): Family fostering behind the dykes:Practice and research. www.uni-siegen.de 2009. 01.18.

Szabó Andrea-Bauer Béla-Laki László (szerk.) (2002): Ifjúság 2000 Tanulmányok I. Budapest, Nemzeti Ifjúságkutató Intézet

Szabó László Tamás (1988): A rejtett tanterv. Budapest, Magvető Könyvkiadó

Szikulai István (2004): „Nem szeretném, hogy befejeződjön” A gyermekvédelmi rendszerből nagykorúságuk után kikerült fiatal felnőttek utógondozásának és utógondozói ellátásának utánkövetéses vizsgálata. In Papházi Tibor (szerk.): Javitóintézet, család, gyermekvédelem. Budapest, NCSSZI

Szikulai István (2004): A magyar gyermekvédelem fejlődésének kulcskérdései -egy lehetséges szakmai stratégia lépései. Kapocs, 3. 14. sz. 58-64. 
Tapsfield R.-Collier F., (2008): A nevelőszülői ellátás költségei. Kapocs, 7. 35. Sz. 48-56.

Thiersch H.-Dieter B.-Finkel M.-Hamberger M.-Kühn A.(1998): Leistungen und Grenzen von Heimerziehung Ergebnisse einer Evaluationsstudie stationarer und teilstatonarer Erziehungshilfen. www.bmfsfj.de/RedaktionBMFSJ/Broschuerenstelle/pdfanalgen/band_20170_vorwort,property=pdf 2010.03.30.

Tóth Judit Nikoletta (szerk.)(2004): A gyermekvédelmi szakellátás helyzete a XX. században. Budapest, KSH

Trede W. (1993): A nevelőotthoni nevelés reformja és fejlődése Németországban a „,nevelőotthoni kampány” óta. In Blumenfeldné Mikola Júlia-Volentics Anna (szerk): Pszichopedagógia Nevelőotthoni nevelés II. Budapest, Nemzeti Tankönyvkiadó

TRANSMONEE 2007 Features. Data and analyzis on the lives of children in CEE/ CIS and Baltic States. Florence, UNICEF IRC.

UNICEF (1997): Children at risk in Central and Eastern Europe: perils and promises, Economies in Transition Studies. Regional Monitoring Report No. 4. Florence, Italy

UNICEF (2003): A league table of child maltreatment deaths in rich nations. Innocenti Report Card No. 5. szeptember 2003. Florence, UNICEF Innocenti Research Centre

UNICEF (2006): Innocenti Social Monitor 2006. Understanding Child Poverty in South-Eastern Europe and the Commonwealth of Independent States. Florence, UNICEF, Innocenti Research Centre

UNICEF (2003): A league table of child maltreatment deaths in rich nations. Innocenti Report Card No. 5. szeptember 2003. Florence, UNICEF Innocenti Research Centre

UNICEF (2003): Children in institutions: The beginning of the end? Florence, UNICEF, Innocenti Research Centre

Utasi Ágnes (2002): Társadalmi integráció és családi szolidaritás. Educatio, 11. 3.sz. 384-403.

Utasi Ágnes (1989): Családok és életstílusok. Budapest, MSZMP KB Társadalomtudományi Intézete

Vajda Zsuzsanna- Kósa Éva (2004): Neveléslélektan. Budapest, Osiris.

Varga Aranka (2008): A gyermekvédelmi gondoskodásban élők inklúziójának esélyei. Új Pedagógiai Szemle, 58. 5. sz. 16-24.

Vavró István (1999): Bünözés és áldozattá válás. http://www.tarsadalomkutatas. hu/kkk.php?TPUBL-A-446/publikaciok/tpubl_a_446.pdf 2012.11. 10.

Veres Sándor- Brezovszky László (1989): A képzettségi hátrányok okai az állami gondozottak körében. Gyermek- és ifjúságvédelem, 8. 1. sz. 67-78.

Vidaud D.,(1991): Residential Education and care in France. In Gottesmann (eds.): Residential Child Care An international reader. London, Whiting \& Birch LTD 
Vidra-Szabó Ferenc (2001): „Soha többé nem megyek haza”. Gyerekek állami gondozásban. Esély, 12. 5. sz.

Volentics Anna (1996): Gyermekvédelem és reszocializáció. Budapest, Nemzeti Tankönyvkiadó

Zrinszky László (2002): Neveléselmélet. Budapest, Müszaki Könyvkiadó

Zsámbéki Eszter (2004): A lakásotthonban élő gyermekek helyzete. Család, Gyermek, Ifjúság, 13. 2. sz. 5-19. 


\section{FELHASZNÁLT TÖRVÉNYEK, STATISZTIKAI ADATOK FORRÁSA}

1997. évi XXXI. Törvény a gyermekek védelméröl és a gyámügyi igazgatásról forrás: A szociális munka és a gyermekvédelem jogi kézikönyve Kjk. Kerszöv, Budapest.

Angol statisztikai adatok forrása: British Association for Adoption \& Fostering www.baaf.org.uk 2010.09.13.

Central Statistical Office, Poland (2006): System in support of children without parental care in the Poland. Warsaw: Central Statistical Office. Country Analytical Report prepared for the MONEE Project. Florence, UNICEF, IRC.

Czech Statistical Office (2006): System in support of children without parental care in the Czeh Republic, Prague: Czeh Statistical Office. Country Analytical Report prepared for the MONEE Project. Florence, UNICEF, IRC

Demográfiai Évkönyv. 2006. Budapest, KSH

Francia statisztikai adatok forrása: National Institute of Statistics an Economic Studies www.INSEE.fr/en/default.asp. 2010.01.10.

Német statisztikai adatok forrása Statistiches Bundesamt Deutschland www. destatis.de/jetspeed/portal/cms/Sites/destatis/Internet/EN/Content/Statiststic 2010.01.10.

Népszámlálás 2001 2. Részletes adatok a képviseleti minta alapján. Budapest, $\mathrm{KSH}$

Népszámlálás 2001 Gyermek a családban. Budapest, KSH

Népszámlálás 2001 19. Családtípusok, családformák. Budapest, KSH

Szociális védöháló a régiókban 2008. Budapest, Központi Statisztikai Hivatal

Tájékoztató a család, gyermek- és ifjúságvédelem helyzetéröl. Budapest, SZMM Gyermek- és ifjúságvédelmi főosztály 


\section{FELHASZNÁLT DOKUMENTUMOK}

A nevelőotthoni nevelés továbbfejlesztett programja. 1976.

Berényi Magdolna, Huberné Kuncsik Zsuzsa, Valu Tibor (2004): A helyi önkormányzatok gyermekvédelmi szakellátási tevékenységének ellenörzéséröl. www. asz.hu 2010. 06. 23. 


\section{TÁBLÁZATOK JEGYZÉKE}

1. táblázat A családok családösszetétel és a száz családra jutó gyermekek száma szerint, 1970-2001 ......................................................... 15

2. táblázat Az egyszülős családok számának és összetételének alakulása,

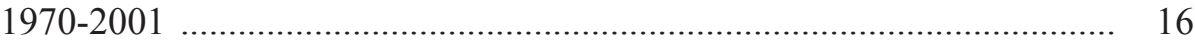

3. táblázat A házaspáros típusú családok számának alakulása, 1970-2001 _... 18

4. táblázat Tévénézésre fordított áltagos napi idő hétköznap és hétvégén korcsoportonként, 2004-2008 ……................................................. 22

5. táblázat Családjukból kiemelt gyermekek életkori megoszlása Angliában 2007

6. táblázat Gyermekvédelmi gondoskodásban elhelyezett gyerekek száma Csehországban 44

7. táblázat Elhelyezési központok Romániában 46

8. táblázat Állami gondozásban részesülő gyerekek száma 1989-1995 (100.000 gyerekre vetítve)

9. táblázat Gyermekvédelmi gondoskodásban részesülő gyerekek 2005

10. táblázat Gyermekvédelmi gondoskodásba vett gyerekek gondozási helye

11. táblázat Gyermeklétszám alakulása a csecsemőotthonokban 2005 .......... 59

12. táblázat Férőhelyek és gyermekek száma az ellátás típusa szerint 2005 .. 60

13. táblázat Általános iskolát végzettek továbbtanulási arányának megoszlása 1990-2002

14. táblázat 2004/2005-ös tanévben az általános iskolát befejezettek továbbtanulása

15. táblázat Gyermekotthoni gyermekcsoportok száma 2005 ..................... 65

16. táblázat Férőhelyek és gyermekek száma az ellátás típusa szerint 2005 .. 67

17. táblázat Szökések, szökési esetek száma gondozási hely szerint 2005 .... 68

18. táblázat Utógondozói ellátásban részesülő fiatalok száma tartózkodási hely szerint 2005 70

19. táblázat Nevelőszülők száma 2005

20. táblázat Növendékek száma a beutalást megelőző állandó tartózkodási hely és a végzett tevékenység szerint 2005

21. táblázat A minta megoszlása nem és elhelyezési hely szerint .. 102

22. táblázat Rendelkezésre álló szabadidő

23. táblázat Tévézéssel és zenehallgatással töltött idő megoszlása 121

24. táblázat A növendékek tanulmányaira vonatkozó adatok

25. táblázat Mennyire fontosak az alábbi értékek az Ön életében? (az Ifjúság 2000, 2004 és a saját adatfelvétel összehasonlítása) 
26. táblázat Mennyire fontosak az alábbi értékek az Ön életében? (az Ifjúság 2004 és a gyermekotthoni, lakásotthoni adatfelvétel összehasonlítása) .... 132 27. táblázat Az alkoholt kipróbálók és használók megoszlása ..................... 134 28. táblázat Dohányzást kipróbálók és dohányzás gyakoriság szerinti

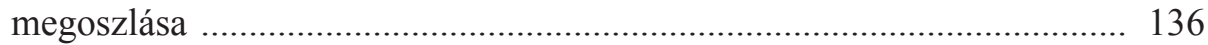

29. táblázat Milyen könnyen tudja megbeszélni a problémákat ..................... 140 


\section{ÁBRÁK JEGYZÉKE}

1. ábra Bronfenbrenner ökológiai modellje ................................................ 27

2. ábra Gyermekotthonokban és nevelőszülőknél elhelyezett gyerekek aránya

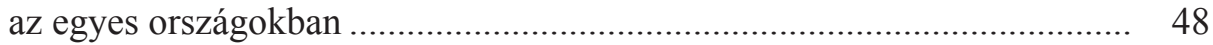

3. ábra Csecsemőotthoni férőhelyek alakulása ............................................ 58

4. ábra Az intézménybe kerülés életkor szerint ....................................... 102

5. ábra Az intézménybe való bekerülés előzménye ..................................... 103

6. ábra A szülők iskolai végzettsége ....................................................... 105

7. ábra A problémák megbeszélésének lehetőségei ...................................... 108

8. ábra Az intézményekben élők barátai lakóhely szerint............................... 111

9. ábra Kulturális intézmények látogatásának gyakorisága a gyermekotthonban élök körében .......................................................... 116

10. ábra Kulturális intézmények látogatásának gyakorisága a lakásotthonban

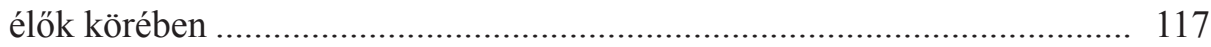

11. ábra Az intézményekben élő gyerekek továbbtanulási tervei ................... 128

12. ábra Az intézményben élő fiatalok elégedettsége jelenlegi életükkel....... 141 

Kiadta: Belvedere Meridionale Szeged

Müszaki szerkesztő: Szuperák Attila

Nyomta: S-Paw Bt., Üllés 